\title{
A gestão ambiental do pólo industrial de Cubatão a partir do programa de controle da poluição iniciado em 1983: atores, instrumentos e indicadores
}

\author{
Liliane Garcia Ferreira
}

Dissertação apresentada ao Programa de Pós-graduação em Saúde Pública da Faculdade de Saúde Pública da Universidade de São Paulo para obtenção do título de Mestre em Saúde Pública.

Área de concentração: Saúde Ambiental Orientador: Prof. Dr. Arlindo Philippi Jr

São Paulo

2007 
É expressamente proibida a comercialização deste documento, tanto na sua forma impressa como eletrônica. Sua reprodução total ou parcial é permitida exclusivamente para fins acadêmicos e científicos, desde que na reprodução figure a identificação do autor, título, instituição e ano da tese/dissertação. 
Ao meu amor, José Marcelo Marton, pelo carinho, companheirismo, dedicação e compreensão diários, além da valiosa contribuição com seus conhecimentos e experiência.

À minha família, em especial aos meus pais, Antônio e Maria Rosa, pelo carinho, incentivo e apoio incondicionais em todos os momentos da minha vida. 


\section{AGRADECIMENTOS}

Ao Prof. Arlindo Philippi Junior, pela confiança e paciência com as quais me orientou durante todo o desenvolvimento deste trabalho, sempre me incentivando com seu entusiasmo.

Aos professores da banca examinadora: Prof ${ }^{\mathrm{a}}$ Ana Maria de Oliveira Nusdeo, Prof.

Luis Enrique Sánchez, Prof. Tadeu Fabrício Malheiros e Prof. Pedro Caetano

Sanches Mancuso, pela valiosa contribuição ao compartilharem seus conhecimentos.

À CETESB, em especial aos funcionários da agência ambiental de Cubatão, sempre dispostos a colaborar com dados, informações e documentos.

Aos colegas da pós-graduação, em especial a Maria Luiza, pelo precioso apoio durante a realização de todo este trabalho.

À amiga Margarida, pelo imprescindível apoio e cooperação. 
"A terra pode oferecer o suficiente para satisfazer as necessidades de todos os homens, mas não a ganância de todos os homens" Mahatma Gandhi 


\section{RESUMO}

FERREIRA, L. G. A gestão ambiental do pólo industrial de Cubatão a partir do Programa de Controle da Poluição iniciado em 1983: atores, instrumentos e indicadores. [Dissertação de Mestrado]. São Paulo: Faculdade de Saúde Pública da USP; 2007.

Introdução - Destaca a necessidade de políticas públicas e de uma gestão ambiental adequadas para a promoção do desenvolvimento sustentável, a partir da avaliação da experiência de controle da poluição em Cubatão, do início do Programa de Controle da Poluição Ambiental, em 1983, até 2005. Objetivo - Descrever os resultados alcançados em Cubatão, sob o enfoque do desenvolvimento sustentável, por meio de indicadores ambientais, econômicos, sociais e institucionais, avaliando os instrumentos utilizados e o papel desempenhado pelos atores envolvidos, bem com obter a visão desses atores sobre os fatores determinantes desses resultados. Verificar a suficiência das informações existentes para a avaliação do progresso do município na direção do desenvolvimento sustentável e a possibilidade de proposição de indicadores. Identificar a visão da coletividade sobre a gestão ambiental do pólo industrial de Cubatão desenvolvida nos anos mais recentes do período da pesquisa. Métodos - Dados secundários obtidos de fontes bibliográficas e dados primários obtidos pela aplicação de questionário a população constituída de pessoas dos diversos setores envolvidos na evolução do controle da poluição em Cubatão. Os resultados deste foram analisados quantitativamente, por cálculos percentuais, bem como qualitativamente, pela metodologia do discurso do sujeito coletivo. Resultados

- Houve melhoria dos indicadores ambientais e econômicos de Cubatão, porém os sociais e institucionais não acompanharam essa evolução. O Programa de Controle da Poluição executado pela CETESB foi o instrumento mais importante utilizado, sendo fundamental a atuação desse órgão, em conjunto com a sociedade civil. Essa também foi a visão dos atores envolvidos. Não foi possível encontrar indicadores suficientes para a avaliação do desenvolvimento sustentável em Cubatão, sendo necessário propor indicadores. Segundo os participantes da pesquisa, a gestão ambiental do pólo industrial de Cubatão apresenta diversos problemas, sendo enfatizada a gestão em consonância com as exigências do desenvolvimento sustentável como o melhor caminho para o município. Conclusões - Os dados 
demonstram que o desenvolvimento do município não vem sendo efetuado em bases sustentáveis, sendo fundamental para tanto a atuação integrada e pró-ativa do setor governamental, empresarial e sociedade civil, bem como a existência de instrumentos adequados. As informações existentes sobre o município são insuficientes, havendo necessidade de um sistema de informações adequado. Segundo o discurso do sujeito coletivo produzido, a gestão ambiental do pólo industrial de Cubatão deve ser fundamentada na harmonização de objetivos ambientais, econômicos e sociais.

Descritores: Cubatão; Controle de poluição; Gestão ambiental; Desenvolvimento sustentável; Indicadores. 


\begin{abstract}
FERREIRA, L. G. A gestão ambiental do pólo industrial de Cubatão a partir do Programa de Controle da Poluição iniciado em 1983: atores, instrumentos e indicadores./Environmental management in the Cubatão industrial cluster by means of a Pollution Control Program launched in 1983: actors, instruments and indicators. [dissertation]. São Paulo (BR): Faculdade de Saúde Pública da Universidade de São Paulo, 2007.
\end{abstract}

Introduction - This paper highlights the need of suitable public policies and environmental management to promote sustainable development by assessing the Cubatão Environmental Pollution Control Program experience from 1983 to 2005. Goal - To describe the results achieved in Cubatão from the sustainable development standpoint by making use of institutional, social, economic and environmental indicators, and assessing the instruments used and the role played by the actors. To investigate those actors' view of the factors which determined those results. To check whether the existing information was sufficient when assessing the municipality's progress on the path of sustainable development, and whether it was possible to propose indicators. To identify how the population views the environmental management of the Cubatão industrial cluster undertaken in the last years of the research period. Methods - Secondary data from bibliographic sources and primary data obtained by means of a questionnaire applied to people from the several sectors engaged in improving pollution controls in Cubatão. The results were analyzed quantitatively, through percentage calculation, and qualitatively, by means of the collective subject discourse methodology. Results - The environmental and economic indicators of Cubatão improved, while the social and institutional indicators did not improve at the same rate. Cetesb's Pollution Control Program was the most important instrument used, with its action being critical along with civil society's action. That view is also shared by the actors involved. It was not possible to find sufficient indicators to assess sustainable development in Cubatão, which made it crucial to propose indicators. According to those taking part in the survey, environmental management in the Cubatão industrial cluster presents several problems, which requires placing emphasis on management complying with the requirements of sustainable development as the best solution to the problems faced 


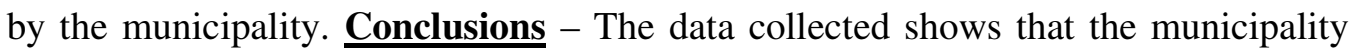
has not been developing in a sustainable manner. In order to do so, it is imperative that civil society, government and business sectors take integrated and proactive action, and make use of suitable instruments. The data about the municipality are insufficient, which makes a suitable information system necessary. According to the resulting collective subject discourse, environmental management in the Cubatão industrial cluster must be based on harmonizing social, economic and environmental goals.

Keywords: Cubatão; Pollution control; Environmental management; Sustainable development; Indicators. 


\section{ÍNDICE}

1 INTRODUÇÃO 1

2 REFERENCIAL TEÓRICO 4

2.1 DESENVOLVIMENTO SUSTENTÁVEL 4

2.1.1 O Processo Político de Conscientização Mundial 4

2.1.2 As Diferentes Abordagens Conceituais do Desenvolvimento Sustentável 10

2.2 POLÍTICAS PÚBLICAS AMBIENTAIS E GESTÃO AMBIENTAL 17

2.2.1 Políticas Públicas Ambientais 17

2.2.2 Instrumentos de Política Pública Ambiental 21

2.2.3 A Política Pública Ambiental Brasileira 29

2.2.4 Gestão Ambiental Pública 37

2.2.5 Gestão Ambiental no Setor Industrial 42

2.2.6 Sistemas de Gestão Ambiental 48

2.3 INDICADORES DE DESENVOLVIMENTO SUSTENTÁVEL 52

2.3.1 A Informação no Processo de Promoção do Desenvolvimento Sustentável $\quad 52$

2.3.2 A Importância dos Indicadores na Gestão Ambiental 55

2.3.3 Limitações no Processo de Construção e Utilização de Indicadores $\quad 57$

2.3.4 A Busca por Indicadores de Desenvolvimento Sustentável:

Experiências Internacionais $\quad 59$

2.3.5 Experiências do Brasil 64

2.4 CASOS SIMILARES EM OUTROS PAÍSES $\quad 69$

2.4.1 O Caso de Love Canal, nos Estados Unidos 70

2.4.2 O Controle da Poluição na Inglaterra $\quad 72$

2.4.3 A Experiência do Japão $\quad 75$

3. OBJETIVOS 81 
3.1 OBJETIVO GERAL

3.2 OBJETIVOS ESPECÍFICOS

4. METODOLOGIA 82

4.1 LEVANTAMENTO BIBLIOGRÁFICO 82

4.2 SELEÇÃO DE INDICADORES

4.3 O QUESTIONÁRIO

4.4 TRATAMENTO DOS DADOS 93

5. RESULTADOS E DISCUSSÃO 98

5.1 O MUNICÍPIO DE CUBATÃO 98

5.1.1 Características Gerais 98

5.1.2 Histórico da Implantação do Pólo Industrial de Cubatão 101

5.1.3 O Contexto de Degradação Ambiental do Município no Início da $\begin{array}{ll}\text { Década de } 1980 & 105\end{array}$

5.2 O PROGRAMA DE CONTROLE DA POLUIÇÃO AMBIENTAL EM CUBATÃO

5.2.1 Breve Histórico do Contexto Político da Criação do Programa de Controle da Poluição Ambiental em Cubatão

5.2.2 O Programa de Controle da Poluição Ambiental em Cubatão

5.3 DESCRIÇÃO E AVALIAÇÃO DA EVOLUÇÃO DOS INDICADORES AMBIENTAIS, ECONÔMICOS, SOCIAIS E INSTITUCIONAIS DE CUBATÃO

5.4 AVALIAÇÃO DAS INFORMAÇÕES DISPONÍVEIS SOBRE CUBATÃO E A NECESSIDADE DE NOVOS INDICADORES PARA O MUNICÍPIO

5.5 OS PRINCIPAIS FATORES DETERMINANTES DA EVOLUÇÃO DO CONTROLE DA POLUIÇÃO EM CUBATÃO, SEGUNDO OS ATORES ENVOLVIDOS

5.6 A ATUAL GESTÃO AMBIENTAL DO PÓLO INDUSTRIAL DE CUBATÃO: O DISCURSO DO SUJEITO COLETIVO 
5.7 INFORMAÇÕES SOBRE SISTEMAS DE GESTÃO AMBIENTAL NAS INDÚSTRIAS 214

6. CONCLUSÕES 217

7. CONSIDERAÇÕES GERAIS E RECOMENDAÇÕES 225

8. REFERÊNCIAS BIBLIOGRÁFICAS 228 ANEXOS

Anexo 1 - Questionário

Anexo 2 - Quadros sinópticos dos indicadores de desenvolvimento sustentável utilizados na pesquisa 


\section{Lista de Tabelas}

Tabela 1 - Instrumentos de Política Pública Ambiental - Classificação e Exemplos 22

Tabela 2 - Índice Paulista de Vulnerabilidade Social $\quad 68$

Tabela 3 - Emissão de poluentes - distribuição percentual por atividade industrial 106

Tabela 4 - Situação da cobertura florestal das áreas montanhosas em Cubatão nos anos $\begin{array}{ll}1962,1977 \text { e } 1980 & 108\end{array}$

Tabela 5 - Dados de qualidade de água referentes à bacia do Rio Cubatão (1981) 110

Tabela 6 - Emissões diárias de poluentes devido ao tráfego rodoviário para as condições $\begin{array}{ll}\text { de ventos predominantes sul e sudoeste } & 112\end{array}$

Tabela 7 - Estimativa de emissão de poluentes atmosféricos no município de Cubatão em toneladas/mês

Tabela 8 - Número de fontes controladas em Cubatão até julho/1985 124

Tabela 9 - Reduções obtidas nos principais poluentes lançados na atmosfera de Cubatão 124

Tabela 10- Redução dos poluentes atmosféricos $\quad 127$

Tabela 11- Redução obtida dos poluentes das águas $\quad 127$

Tabela 12- Geração dos principais poluentes atmosféricos (1984) 129

Tabela 13- Carga remanescente dos principais poluentes atmosféricos (1991) 130

Tabela 14- Geração dos principais poluentes das águas (1984) 131

Tabela 15- Carga remanescente dos principais poluentes das águas (1991) 131

Tabela 16- Índice de qualidade do ar e efeitos sobre a saúde 136

Tabela 17- Frequiência dos fatores da evolução do controle da poluição em Cubatão. 161

Tabela 18- Frequiência de outros fatores apontados para a evolução do controle da 162 poluição em Cubatão 


\section{Lista de Figuras}

Figura 1 - Índice DNA-Brasil 2005

Figura 2 - Estimativa de emissões dos poluentes atmosféricos material particulado (MP), dióxido de enxofre $\left(\mathrm{SO}_{2}\right)$, óxidos de nitrogênio $\left(\mathrm{NO}_{\mathrm{x}}\right)$ e hidrocarbonetos $(\mathrm{HC})$ no período compreendido entre 1985 e 2005

Figura 3 - Distribuição de Frequiência da Pressão da mídia por ordem de importância

Figura 4 - Distribuição de Frequiência das Autuações da CETESB por ordem de importância

Figura 5 - Distribuição de Freqüência da Conscientização ambiental dos dirigentes das Indústrias por ordem de importância

Figura 6 - Distribuição de Freqüências das Ações Civis Públicas movidas pelo Ministério Público por ordem de importância

Figura 7 - Distribuição de Frequiência da Pressão da comunidade por ordem de importância

Figura 8 - Distribuição de Frequiência da Pressão da Comunidade científica por ordem de importância

Figura 9 - Distribuição de Frequiência da Edição da Lei dos crimes ambientais por ordem de importância

Figura 10- Distribuição de Freqüência da Orientação e apoio técnico da CETESB por ordem de importância

Figura 11- Distribuição de Freqüência dos Termos de ajustamento de conduta formulados com o Ministério Público por ordem de importância

Figura 12- Distribuição de Frequiência do Avanço dos conhecimentos científicos e tecnológicos por ordem de importância

Figura 13- Distribuição das Idéias Centrais, segundo os participantes, frente à questão Pontos fracos da gestão atual, Cubatão, São Paulo, 2007

Figura 14- Distribuição das Idéias Centrais, segundo os participantes, frente à questão Pontos fortes da gestão atual, Cubatão, São Paulo, 2007

Figura 15- Distribuição das Idéias Centrais, segundo os participantes, frente à questão Ameaças, Cubatão, São Paulo, 2007 
Figura 16- Distribuição das Idéias Centrais, segundo os participantes, frente à questão Oportunidades, Cubatão, São Paulo, 2007 


\section{Lista de Quadros}

Quadro 1 - Distribuição anual do índice geral de qualidade do ar em Cubatão-Centro

Quadro 2 - Distribuição anual do índice geral de qualidade do ar em Cubatão-Vila Parisi

Quadro 3 - Distribuição anual da qualidade do ar em Cubatão-Centro para o parâmetro Ozônio $\left(\mathrm{O}_{3}\right)$

Quadro 4 - Distribuição anual da qualidade do ar em Cubatão-Centro para o parâmetro Partículas Inaláveis (PI)

Quadro 5 - Distribuição anual da qualidade do ar em Cubatão-Vila Parisi para o parâmetro Partículas Inaláveis (PI)

Quadro 6 - Índice de Qualidade das Águas nos Rios Cubatão, Mogi e Piaçaguera-IQA $20 \%$

Quadro 7 - Produto Interno Bruto (PIB) per capita do município de Cubatão

Quadro 8 - Abastecimento de água - Nível de atendimento em Cubatão

Quadro 9 - Coleta de lixo - Nível de atendimento em Cubatão

Quadro 10 - Esgoto sanitário - Nível de atendimento em Cubatão

Quadro 11 - Taxa de mortalidade infantil em Cubatão

Quadro 12 - Média de Anos de Estudos da População de 15 a 64 Anos

Quadro 13 - População de 25 anos e mais com menos de 8 anos de estudo ( em \%)

Quadro 14 - IDH- Índice de Desenvolvimento Humano do Município de Cubatão

Quadro 15 - Índice Paulista de Responsabilidade Social e Índice Paulista de Vulnerabilidade Social do Município de Cubatão

Quadro 16 - Percentual das Despesas com Gestão Ambiental no Total do Orçamento do Município de Cubatão

Quadro 17 - Ações Civis Públicas (ACPs) Propostas e Termos de Compromisso de Ajustamento de Conduta (TACs) Formalizados pelo Ministério Público

Quadro 18 - Proposta de Indicadores de Desenvolvimento Sustentável para Cubatão

Quadro 19 - Idéias centrais quanto à questão Pontos fracos da gestão atual

Quadro 20 - Idéias centrais quanto à questão Pontos fortes da gestão atual 184

Quadro 21 - Idéias centrais quanto à questão Ameaças 192

Quadro 22 - Idéias centrais quanto à questão Oportunidades 202 


\section{Siglas Utilizadas}

ABIQUIM - Associação Brasileira da Indústria Química

ABNT - Associação Brasileira de Normas Técnicas

AIA - Avaliação de impacto ambiental

AVPMCVC - Associação das Vítimas da Poluição e das Más Condições de Vida de Cubatão

CDS - Comissão de Desenvolvimento Sustentável das Nações Unidas

CETESB - Companhia de Tecnologia de Saneamento Ambiental

CIESP - Centro das Indústrias do Estado de São Paulo

CNUMAD - Conferência das Nações Unidas sobre Meio Ambiente e Desenvolvimento

CONAMA - Conselho Nacional do Meio Ambiente

CONESAN - Conselho Estadual de Saneamento

CONMETRO - Conselho Nacional de Metrologia, Normalização e Qualidade Industrial

CONSEMA - Conselho Estadual do Meio Ambiente

COSIPA - Companhia Siderúrgica Paulista

DAEE - Departamento de Águas e Energia Elétrica do Estado de São Paulo

EPA - United States Environmental Protection Agency

EPIA - Estudo Prévio de Impacto Ambiental

GEF - Global Environment Facility (Programa Ambiental Global)

GEMI - Global Environmental Management Initiative (Iniciativa de Gerenciamento Ambiental Global)

GPI - Genuine Progress Indicator (Indicador Genuíno de Progresso)

IBAMA - Instituto Brasileiro do Meio Ambiente e dos Recursos Naturais Renováveis

IBGE - Instituto Brasileiro de Geografia e Estatística

IDH - Índice de Desenvolvimento Humano

INMETRO - Instituto Nacional de Metrologia, Normalização e Qualidade Industrial

IPDSC - Instituto de Pesquisa do Discurso do Sujeito Coletivo Ltda

IPRS - Índice Paulista de Responsabilidade Social

IPVS - Índice Paulista de Vulnerabilidade Social

IQA - Índice de Qualidade das Águas 
ISA - Índice de Salubridade Ambiental

ISEW - Index of Sustainable Economic Welfare (Índice de Bem-Estar Econômico Sustentável)

ISO - International Organization for Standardization (Organização Internacional de Padronização)

IUCN - International Union for the Conservation of Nature and Natural Resources (União Internacional para Conservação da Natureza e dos Recursos Naturais)

MAPAC - The Manchester Area Pollution Advisory Council (Conselho Consultivo de Poluição da Área de Manchester)

NEPP - Núcleo de Estudos de Políticas Públicas da Unicamp

ONG - Organização não-governamental

ONU - Organização das Nações Unidas

P \& D - Pesquisa e Desenvolvimento

PIB - Produto Interno Bruto

PISA - Programa Internacional para Avaliação do Estudante

PNUD - Programa das Nações Unidas para o Desenvolvimento

PROCOP - Programa de Controle da Poluição

SABESP - Companhia de Saneamento Básico do Estado de São Paulo

SEADE - Fundação Sistema Estadual de Análise de Dados

SISNAMA - Sistema Nacional do Meio Ambiente

TQEM - Total Quality Environmental Management (Administração da Qualidade Ambiental Total)

TQM - Total Quality Management (Administração da Qualidade Total)

UNEP - United Nations Development Programme (Programa de Desenvolvimento das Nações Unidas) 


\section{INTRODUÇÃO}

O desenvolvimento sustentável, fundamentado na harmonização de objetivos sociais, ambientais e econômicos, de modo a atender às necessidades das gerações presentes, sem comprometer a possibilidade de as gerações futuras atenderem às suas próprias necessidades, é hoje um objetivo a ser perseguido por todas as nações do mundo.

O município de Cubatão, sob o enfoque desse conceito, pode ser tido como um dos melhores exemplos do que é o desenvolvimento insustentável. O crescimento econômico promovido no local, com a instalação de inúmeras indústrias, sem qualquer preocupação com os aspectos ambiental e social, acabou gerando um contexto de degradação ambiental extremamente grave. No final da década de 1970 e início da década de 1980, médicos, biólogos e técnicos em saúde pública que realizaram trabalhos e pesquisas no local, detectaram anomalias congênitas, perdas gestatórias e problemas pulmonares graves em crianças e anciões causadas pela poluição.

Esse contexto crítico levou à criação, em 1983, pelo governo do Estado de São Paulo, do Programa de Controle da Poluição Ambiental em Cubatão, sendo a CETESB-Companhia de Tecnologia de Saneamento Ambiental incumbida de sua implementação. Ao longo dos anos vem sendo noticiada a obtenção de efetiva melhoria na qualidade ambiental do município.

Uma comunidade convivendo com um pólo petroquímico e siderúrgico, como é o caso de Cubatão, apresenta alta exposição a uma grande gama de substâncias tóxicas, que se propagam através do ar, solo, água e alimentos, podendo agir, inclusive, de maneira conjugada (GUILHERME, 1988). Esses poluentes, conforme a autora, podem provocar "uma série de doenças que vão da mera irritação dos olhos à necrose da córnea, da dor de cabeça à depressão do sistema nervoso central, da irritação de garganta ao enfisema e edema pulmonares, além de outros efeitos como ulcerações e queimaduras de pele, descalcificação óssea, câncer e leucemia” (p. 115).

Portanto, identificar gestões que levem à melhoria integral e contínua das condições do meio ambiente, que acarretam sempre uma melhoria da qualidade de vida da população nele inserida e, consequentemente, da saúde pública, é vital, 
podendo servir de parâmetro para outros locais e regiões na elaboração de políticas públicas ambientais.

Assim, torna-se de fundamental importância verificar a evolução obtida no controle da poluição no município de Cubatão, a partir do Programa supra mencionado, assim como identificar os instrumentos utilizados para tanto e o papel desempenhado pelos diversos setores da sociedade (governamental, empresarial, sociedade civil) envolvidos nessa tarefa.

Considerando-se, ainda, o objetivo de promoção do desenvolvimento sustentável que deve embasar a formulação das políticas públicas, avaliar o caminho percorrido pelo município nessa direção e a existência de indicadores suficientes e adequados para essa avaliação, bem como para orientar o processo de tomada de decisões também se afigura importante, visto que a existência de informações consistentes é fundamental nesse processo, conforme destacado no capítulo 40, da Agenda 21 Global (UNITED NATIONS, 1992).

No presente trabalho é apresentado, inicialmente, o referencial teórico adotado, partindo do surgimento do conceito de desenvolvimento sustentável, decorrente da conscientização mundial sobre a necessidade de preservação do meio ambiente, passando pela necessidade de políticas públicas e de uma gestão ambiental adequadas para a promoção desse desenvolvimento qualificado, destacando-se a importância da existência de indicadores que possam orientar esse caminho. Foram trazidas, ainda, algumas experiências de outros países no que se refere às ações adotadas em situações semelhantes à do município de Cubatão.

Na sequiência, foi estabelecido o objetivo geral deste trabalho, consistente na descrição da evolução do controle da poluição em Cubatão, apontando os resultados alcançados sob o enfoque do desenvolvimento sustentável, por meio de indicadores ambientais, econômicos, sociais e institucionais, bem como os objetivos específicos: a) avaliar o papel desempenhado pelos atores envolvidos na evolução do controle da poluição em Cubatão; b) obter a visão desses atores sobre os principais fatores determinantes da evolução do controle da poluição no município; c) identificar os principais instrumentos utilizados no processo de melhoria das condições do meio ambiente no município; d) avaliar a suficiência e adequação do sistema de informações existente para a correta avaliação do progresso do município na direção 
do desenvolvimento sustentável; e) avaliar a possibilidade de proposição de novos indicadores; e, f) identificar a visão da coletividade sobre a gestão ambiental do pólo industrial de Cubatão desenvolvida nos anos mais recentes do período da pesquisa e obter eventuais propostas de melhoria.

Para alcançar esses objetivos foi efetuado levantamento sobre as características gerais do município de Cubatão, o histórico de implantação do pólo industrial, bem como sobre o contexto de degradação ambiental que, no início da década de 1980, levou à criação do Programa de Controle da Poluição Ambiental pelo governo do Estado de São Paulo, abordando-se o contexto político da criação do programa. Na sequiência, fez-se uma descrição do programa e dos resultados obtidos durante sua implementação ao longo do período da pesquisa, abordando-se, também os instrumentos utilizados e o papel desempenhado pelos diversos setores sociais envolvidos.

Também foi necessário selecionar os indicadores ambientais, sociais, econômicos e institucionais que pudessem demonstrar os resultados alcançados sob o enfoque do desenvolvimento sustentável, considerando-se as informações disponíveis, avaliando-se a suficiência e adequação do sistema de informações existente para a correta avaliação do progresso do município nessa direção. Foi, ainda, aplicado questionário para obter a visão dos atores envolvidos na evolução do controle da poluição no município sobre os principais fatores determinantes dessa evolução e a visão dessa coletividade sobre a gestão ambiental do pólo industrial de Cubatão desenvolvida nos anos mais recentes do período da pesquisa.

A partir da avaliação e discussão dos resultados obtidos, considerando-se o referencial teórico adotado, foram elaboradas as conclusões do trabalho, com a proposição de indicadores, além de considerações gerais e recomendações, visando contribuir para a melhoria do processo de promoção do desenvolvimento sustentável no país, em especial em Cubatão. 


\section{REFERENCIAL TEÓRICO.}

Neste capítulo são abordados os conceitos básicos e fundamentos teóricos necessários para obter o marco referencial para o desenvolvimento do trabalho, iniciando pelo processo político de conscientização mundial sobre a necessidade de promoção do desenvolvimento sustentável e as diferentes abordagens conceituais dessa expressão, seguido dos conceitos e importância das políticas públicas ambientais, da gestão ambiental e de indicadores nesse processo. Por último, são citadas experiências de controle da poluição em outros países.

\subsection{DESENVOLVIMENTO SUSTENTÁVEL}

\subsubsection{O Processo Político de Conscientização Mundial}

A descoberta da humanidade de que faz parte da natureza e que sem a conservação desta e, conseqüentemente, dos recursos naturais, não haveria futuro para os seres humanos, embora óbvia, demorou a acontecer, sendo despertada especialmente pela ocorrência de diversas catástrofes ambientais de grandes proporções durante as décadas de 1960 e 1980, tais como a da Baía de Minamata, no Japão, de Bhopal, na Índia, da Usina Nuclear de Chernobyl, na antiga União Soviética, e do município de Cubatão, no nosso país.

A necessidade de mudança começou a surgir a partir da constatação de que as atividades humanas estavam reduzindo a capacidade de suporte da vida no planeta, gerando problemas em escala mundial, tais como a chuva ácida, a depleção da camada de ozônio e o efeito estufa (BARBIERI, 1997), bem como que os impactos sobre os seres humanos ocorriam de uma forma socialmente desequilibrada, já que a maioria dos recursos naturais era consumida por uma minoria da população, enquanto a maioria lutava apenas para se manter viva.

Para SACHS (2000), conservação e aproveitamento racional da natureza podem e devem andar juntos. É essencial que caminhemos para uma nova forma de civilização, que tenha como fundamento o aproveitamento sustentável dos recursos 
naturais renováveis, sendo necessário, para tanto, que tenhamos "consciência de que todas as nossas atividades econômicas estão solidamente fincadas no ambiente natural"'(p. 32).

A noção de desenvolvimento sustentável surgiu gradativamente, sendo marcada por diversos acontecimentos, dos quais destaca-se a publicação, em 1972, do relatório sobre os limites do crescimento [The limits to growth], de autoria de um grupo coordenado por Donella Meadows, o qual, "rompe com a idéia da ausência de limites para a exploração dos recursos da natureza, contrapondo-se claramente à concepção dominante de crescimento contínuo da sociedade industrial" (BELLEN, 2005, p. 21).

No mesmo ano em que foi publicado o relatório que, conforme NOBRE (2002), representou um marco que pautou todas as discussões ambientais durante a década de 1970, foi realizada a primeira Conferência das Nações Unidas sobre o Ambiente Humano, na cidade de Estocolmo, onde foram discutidas, pela primeira vez, as dependências entre o desenvolvimento e o meio ambiente, evento que colocou a dimensão do meio ambiente na agenda internacional.

Até a realização da Conferência de Estocolmo prevaleciam duas posições diametralmente opostas que SACHS (2000) denominou de "economicismo arrogante" e "fundamentalismo ecológico". A primeira defendia a aceleração do crescimento como prioridade, argumentando que as preocupações com o meio ambiente eram descabidas, pois sempre poderiam surgir soluções técnicas para garantir a continuidade do progresso material das sociedades humanas. Os ecologistas, de outro lado, defendiam que, caso não houvesse a estagnação imediata do crescimento demográfico e econômico, a humanidade estaria condenada ao desaparecimento em razão da exaustão dos recursos naturais ou dos efeitos da poluição.

$\mathrm{Na}$ Conferência surgiu uma posição intermediária, fundamentada na harmonização de objetivos sociais, ambientais e econômicos, que sustentava a necessidade de crescimento econômico, diante das disparidades existentes entre os países e no interior deles, porém de uma forma socialmente receptiva e implementado por métodos favoráveis ao meio ambiente, com o aproveitamento racional e ecologicamente sustentável da natureza em benefício das populações locais.

A imagem negativa da participação do Brasil em Estocolmo, cuja política econômica defendia como prioridade o crescimento baseado na exploração 
descontrolada dos recursos naturais e na industrialização, "considerando secundárias as externalidades decorrentes da poluição e do esgotamento dos recursos naturais", é lembrada por RIBEIRO (2006, p. 42).

O II Plano Nacional de Desenvolvimento do Brasil, aprovado para o período de 1975-79, ou seja, após a Conferência de Estocolmo, declarou de modo categórico a não validade de qualquer barreira que pudesse limitar o acesso dos países subdesenvolvidos ao estágio de sociedade industrializada, ainda que sob o pretexto de conter o avanço mundial da poluição (BARBIERI, 1997).

O conceito de desenvolvimento sustentável foi apresentado, primeiramente, no documento intitulado World Conservation Estrategy: Living resource conservation for sustainable development [Estratégia de Conservação Mundial: conservação dos recursos vivos para o desenvolvimento sustentável], lançado em 1980, pela International Union for the Conservation of Nature and Natural Resources (IUCN) [União Internacional para Conservação da Natureza e dos Recursos Naturais], o qual advertia para a necessidade de uma nova ordem econômica internacional, bem como de uma nova ética ambiental, além da estabilização da população humana e modelos de desenvolvimento sustentável.

Referida publicação refutou a idéia de que conservação e desenvolvimento são conceitos que se contrapõem, enfatizando que conservação inclui tanto a proteção como o uso racional dos recursos naturais, sendo essencial para a melhoria da qualidade da vida humana e para assegurar o bem-estar das presentes e futuras gerações. Enfatizando a dimensão humana, esse documento afirma que para o desenvolvimento ser sustentável é preciso considerar tanto os fatores sociais e ecológicos como os econômicos, os recursos vivos e não-vivos, bem como as vantagens de curto e longo prazos das ações alternativas. Para tanto, seria necessário alcançar três objetivos principais: a manutenção dos processos ecológicos essenciais, a preservação da diversidade genética e o uso sustentável de espécies e ecossistemas (IUCN et al, 1980).

As mudanças de atitude em relação à natureza são bastante recentes. Segundo VEIGA (2006, p. 19), a “expressão 'desenvolvimento sustentável' foi publicamente empregada pela primeira vez em agosto de 1979, no Simpósio das Nações Unidas sobre as Inter-relações entre Recursos, Ambiente e Desenvolvimento" e começou a 
se legitimar como um enorme desafio quando foi caracterizada como conceito político por Gro Harlem Brundtland, então presidente da Comissão Mundial sobre Meio Ambiente e Desenvolvimento, perante a Assembléia Geral da ONUOrganização das Nações Unidas, em 1987.

O conceito de desenvolvimento sustentável definido no relatório "Nosso Futuro Comum", elaborado por essa comissão, também denominada Comissão Brundtland, como sendo "aquele que atende às necessidades do presente sem comprometer a possibilidade de as gerações futuras atenderem às suas próprias necessidades", é aquele que alcança consenso até hoje (CMMAD, 1991, p. 46).

Segundo o entendimento firmado no mencionado relatório, meio ambiente, desenvolvimento econômico e justiça social são aspectos de um mesmo sistema, que estão inevitavelmente interligados, já que o desenvolvimento não se mantém sem uma base de recursos ambientais, bem como não pode haver proteção do meio ambiente se o crescimento não levar em consideração as consequências da destruição ambiental. Portanto, para promover o desenvolvimento sustentável, é necessário integrar economia e ecologia nos processos decisórios e legislativos. Contudo, não basta a integração economia-ecologia, posto que os problemas dos dois setores estão ligados a vários fatores sociais e políticos. Daí a necessidade de incluir programas de desenvolvimento social.

O conceito proposto pela Comissão Brundtland foi adotado por diversos governos, dentre eles, o do Brasil, ao estabelecer na Constituição Federal de 1988, o direito de todos "ao meio ambiente ecologicamente equilibrado, bem de uso comum do povo e essencial à sadia qualidade de vida, impondo-se ao Poder Público e à coletividade o dever de defendê-lo e preservá-lo para as presentes e futuras gerações" (BRASIL, 1988), passo importante em direção ao desenvolvimento sustentável.

A UICN publicou em 1991, uma revisão da World Conservation Estrategy [Estratégia de Conservação Mundial], sob o título Caring for the Earth. A strategy for sustainable living [Importar-se com a Terra. Uma estratégia para a vida sustentável], que traz o conceito de "sociedade sustentável”, como aquela que vive segundo os seguintes princípios: "1- respeitar e cuidar da comunidade dos seres vivos; 2- melhorar a qualidade da vida humana; 3- conservar a vitalidade $e$ diversidade do Planeta Terra; 4- minimizar o esgotamento de recursos não 
renováveis; 5- permanecer nos limites da capacidade de suporte do Planeta Terra; 6- modificar atitudes e práticas pessoais; 7- permitir que as comunidades cuidem de seu próprio meio ambiente; 8- gerar uma estrutura nacional para a integração de desenvolvimento e conservação; 9- constituir uma aliança global” (traduzido de IUCN, 1991).

Em junho de 1992, vinte anos após a conferência de Estocolmo, ocorreu a Conferência das Nações Unidas sobre Meio Ambiente e Desenvolvimento (CNUMAD), no Rio de Janeiro, conhecida informalmente como Cúpula da Terra, que contou com a presença de representantes de 178 países, resultando na construção da Declaração do Rio sobre Meio Ambiente e Desenvolvimento, da Declaração de Princípios sobre o Uso das Florestas, da Convenção das Nações Unidas sobre Diversidade Biológica, da Convenção das Nações Unidas sobre Mudanças Climáticas e da Agenda 21 Global.

A Conferência do Rio objetivou a consagração do ideal de desenvolvimento sustentável, no esforço para compatibilizar prosperidade econômica, preservação ambiental e equidade social para as presentes e futuras gerações, merecendo destaque, conforme RIBEIRO (2006), a aprovação da Agenda 21 que, embora inicialmente tenha sido construída com o escopo de se constituir em um plano de ação para a implementação do desenvolvimento sustentável e de um tratado geral sobre transferência de tecnologia, permaneceu apenas com o mérito de se tornar uma carta de princípios universais para orientar o desenvolvimento sustentável.

A Rio-92, segundo NOBRE (2002), caracteriza-se como ponto culminante do projeto de institucionalização da problemática ambiental, fazendo com que as preocupações ambientais passassem a ocupar o primeiro plano da agenda política internacional e a integrar as decisões sobre políticas públicas em todos os níveis, além de representar o ponto de partida de um novo arranjo teórico e político do debate ambiental.

Em continuidade à Conferência do Rio, foram realizadas, em 1997, em Nova Iorque, Estados Unidos, e em 2002, em Johannesburgo, África do Sul, respectivamente, as conferências conhecidas como Cúpula da Terra+5 e Cúpula Mundial sobre Desenvolvimento Sustentável ou Rio+10, com a finalidade de avaliar 
os avanços obtidos até então, reafirmar os compromissos para o desenvolvimento sustentável e definir as prioridades para os anos seguintes.

Da avaliação realizada no encontro ocorrido em 1997, constatou-se que poucos tinham sido os avanços obtidos, uma vez que apenas um número limitado de países em desenvolvimento havia sido capaz de se beneficiar da acelerada globalização na área do comércio mundial, havendo permanência ou piora da situação econômica e social da maioria deles. O encontro foi caracterizado por um intenso debate entre o norte e o sul, motivo pelo qual poucos compromissos foram firmados (UNITED NATIONS, 1997).

O mesmo ocorreu em Johannesburgo, onde se verificou que poucas das diretrizes acordadas na Rio-92 haviam sido implementadas, embora muitos países, Estados e municípios tenham construído suas Agendas 21. O principal resultado desse encontro foi a redação de uma Declaração Política e um Plano de Implementação de ações prioritárias, em especial nos países em desenvolvimento, versando sobre erradicação da pobreza, mudança nos padrões insustentáveis de produção e consumo, proteção e gerenciamento dos recursos naturais, saúde e desenvolvimento sustentável (UNITED NATIONS, 2002).

Além de reafirmar os princípios da Conferência do Rio, a declaração resultante da Conferência de Johannesburgo firmou comprometimento para a adoção, dentre outros, dos objetivos constantes da Declaração do Milênio das Nações Unidas, aprovada na Cimeira do Milênio, realizada em 2000, em Nova Iorque: erradicação da pobreza extrema e da fome; universalidade do ensino básico; promoção da igualdade entre os sexos e autonomia das mulheres; redução da mortalidade infantil; melhora da saúde materna; combate ao HIV/AIDS, à malária e outras doenças; garantia da sustentabilidade ambiental; e estabelecimento de uma parceria mundial para o desenvolvimento (UNITED NATIONS, 2000).

A influência dessas e outras contribuições mantêm-se vivas, funcionando como fermento para as idéias e propostas discutidas na atualidade para a transformação radical de paradigmas e modelos de desenvolvimento humano e de acesso e distribuição de riquezas.

Felizmente, afirma SACHS (2000, p. 49), a pretensão de domínio da natureza, paradigma básico do pensamento científico, e a crença ilimitada nas 
virtudes do progresso científico vêm sendo abandonadas, dando lugar à "ética imperativa da solidariedade" para com as gerações presentes e futuras, bem como para com todos os seres vivos na Terra.

\subsubsection{As Diferentes Abordagens Conceituais do Desenvolvimento Sustentável}

Como se pode verificar do exposto no item anterior, o conceito de desenvolvimento sustentável vem sendo construído ao longo do tempo, em um processo continuo e complexo, resultando em uma enorme variedade de abordagens, segundo o campo ideológico ou a dimensão adotada, algumas das quais serão aqui mencionadas, sem a pretensão de esgotar o tema, que não é objetivo deste trabalho.

A definição mais conhecida e aceita de desenvolvimento sustentável, como já mencionado no item 2.1.1., é aquela dada pelo Relatório Bundtland, que o caracterizou como um conceito político e um conceito amplo para o progresso econômico e social, fundamentado na harmonização de objetivos sociais, ambientais e econômicos a nível mundial, uma vez que, além dos sistemas ambiental, econômico, político e social estarem interligados, ultrapassam fronteiras geográficas. A definição de desenvolvimento sustentável como aquele que atende às necessidades do presente sem comprometer a possibilidade de as gerações futuras atenderem às suas próprias necessidades, integra dois conceitos-chave: o conceito de "necessidades", que determina a máxima priorização das necessidades essenciais dos pobres do mundo, e a noção de limitações impostas ao meio ambiente pelo estágio da tecnologia e da organização social, que o impede de atender às necessidades presentes e futuras. Segundo o relatório, desenvolvimento sustentável, em essência, “é um processo de transformação no qual a exploração dos recursos, a direção dos investimentos, a orientação do desenvolvimento tecnológico e a mudança institucional se harmonizam e reforçam o potencial presente e futuro, a fim de atender às necessidades e aspirações humanas" (CMMAD, 1991, p. 49).

Segundo VEIGA (2006), delimitando um vasto campo em que se dá a luta

política sobre o sentido que deveria ter o meio ambiente no mundo contemporâneo, o conceito trazido pelo relatório fez com que a dimensão da sustentabilidade passasse a permear a formulação e a implantação de políticas públicas em todos os níveis dentro 
dos países e nos órgãos multilaterais e de caráter supranacional. O autor busca compreender o conceito de desenvolvimento sustentável, a partir de uma análise do debate entre a evolução da teoria do desenvolvimento e o crescimento.

O desenvolvimento econômico, conforme Veiga, é uma versão do desenvolvimento natural, porém os modelos econômicos convencionais sempre ignoraram a união entre os sistemas econômicos e bióticos, desdenhando a existência de limites naturais, fato que impossibilitou por muito tempo a inserção de condicionantes de ordem ecológica nas políticas econômicas. O recurso inicial da economia de qualquer comunidade surge da combinação de dádivas da natureza, ou seja, da existência de um recurso ou de uma combinação de recursos disponíveis, com trabalho humano, principal ingrediente do ponto de vista qualitativo do desenvolvimento. A teoria do desenvolvimento ficou circunscrita, nos últimos duzentos anos, à lógica dos meios, sendo a criatividade do homem canalizada para a criação técnica, o quê explica sua extraordinária capacidade expansiva. Contudo, desenvolvimento deve ser compreendido "como processo de transformação da sociedade não só em relação aos meios, mas também aos fins", sendo "o principal fim e o principal meio do desenvolvimento" a expansão da liberdade (p. 135).

O crescimento econômico é um fator importante para o desenvolvimento, porém naquele a mudança é quantitativa, enquanto neste é qualitativa, envolvendo outros aspectos como saúde, educação e direitos civis. A negação ou restrição de liberdades elementares pode estar vinculada à pobreza econômica que, muitas vezes, impede a liberdade de saciar a fome, obter nutrição satisfatória, remédios, moradia adequada, acesso à água tratada ou ao saneamento básico. Em outros casos, está associada à carência de serviços públicos e assistência social, havendo, ainda, situações em que se relaciona diretamente à negação de liberdades políticas e civis por regimes autoritários e restrições à participação na vida social, política e econômica da comunidade, motivo pelo qual o desenvolvimento é relevante até mesmo para países considerados muito ricos.

O adjetivo "sustentável”, afirma Veiga, tem três tipos básicos de usuários: em um extremo estão aqueles que não acreditam que exista real dilema entre conservação ambiental e crescimento econômico; no outro, os apocalípticos; e no meio, a maioria dos analistas não dogmáticos, com variadas posições. $\mathrm{O}$ denominado 
"caminho do meio", que se situa entre "a miopia que reduz o desenvolvimento ao crescimento, e o derrotismo que o descarta como inexeqüível" (p. 162-163) relaciona o desenvolvimento com a possibilidade das pessoas viverem o tipo de vida que escolheram, com a provisão dos instrumentos e das oportunidades para fazerem suas escolhas. O desenvolvimento, nesse caminho, vai desde a proteção dos direitos humanos até o aprofundamento da democracia, pela possibilidade de efetiva participação política de todos.

O desenvolvimento sustentável faz-se com sustentabilidade ambiental do crescimento e melhoria da qualidade de vida, sendo crucial que sejam feitos dois tipos de escolha: planejamento de longo prazo e disposição para reconsiderar antigos valores. A visão de Veiga enfatiza a dimensão humana, posto que para o autor, "só há desenvolvimento quando os benefícios do crescimento servem à ampliação das capacidades humanas, entendidas como o conjunto das coisas que as pessoas podem ser, ou fazer, na vida" (p. 23). Tendo como pré-requisito a liberdade de escolha, quatro seriam as capacidades mais importantes para avaliar o progresso mundial na realização do bem-estar humano: vida longa e saudável; conhecimento; acesso aos recursos necessários para um padrão de vida digno; participação na vida da comunidade (VEIGA, 2006).

O autor adverte que tem havido uma banalização do termo "sustentável", passando o debate sobre o desenvolvimento sustentável a girar, muitas vezes, em torno da idéia de durabilidade, o que é um equívoco. A expressão desenvolvimento sustentável se legitimou para afirmar a possibilidade de conciliação entre crescimento econômico contínuo e conservação do meio ambiente, ou seja, se e em quê condições esse processo poderia não ser comprometido pela destruição de seus próprios alicerces naturais.

A necessidade de acrescer o qualificativo "sustentável" à noção de desenvolvimento reflete o crescente esgotamento de um dos principais valores dos tempos modernos: os recursos naturais. O desenvolvimento sustentável é aquele que, no longo prazo, seja capaz de estabelecer um equilíbrio entre a humanidade, os recursos naturais renováveis que ela consome e o efeito de suas atividades sobre o meio ambiente. Não há qualquer certeza sobre os níveis de população, tecnologia e consumo que devam ser estabelecidos para tornarem possível esse equilíbrio 
permanente, problema que, segundo o autor, não é científico ou tecnológico, mas político e social (VEIGA, 2006).

Na visão de SACHS (2000), o desenvolvimento sustentável deve atender simultaneamente a três pilares: "relevância social, prudência ecológica e viabilidade econômica" (p. 35), conceituando desenvolvimento como "apropriação efetiva de todos os direitos humanos, políticos, sociais, econômicos e culturais, incluindo-se aí o direito coletivo ao meio ambiente" (p. 60).

O desenvolvimento sustentável, para o autor, impõe a utilização das escalas de tempo e de espaço da ecologia, que diferem em muito daquelas comumente utilizadas pelos economistas, uma vez que na ecologia a escala de tempo se amplia de anos ou décadas, para séculos e milênios, devendo respeitar a capacidade de renovação dos recursos naturais. A ecologia alerta, ainda, para as consequiências espaciais de nossas ações, que podem afetar, em muitos casos, todo o planeta e até mesmo a biosfera. É necessário combinar economia e ecologia de uma maneira viável, integrada, posto que, embora sejam as ciências naturais que descrevam o que é preciso para um mundo sustentável, a articulação das estratégias de transição rumo a esse caminho compete às ciências sociais. O conceito de desenvolvimento sustentável também não escapa do componente ético, que diz respeito à solidariedade com as presentes e futuras gerações e ao respeito à diversidade da natureza.

Segundo SACHS (2000), o conceito de sustentabilidade tem diversas dimensões, sendo a primeira delas, a sustentabilidade social, por ser a própria finalidade do desenvolvimento. Dela decorrem a sustentabilidade cultural, a sustentabilidade do meio ambiente e, como uma necessidade, porém não como condição prévia das demais, a sustentabilidade econômica. Outros corolários da sustentabilidade social dizem respeito à distribuição territorial equilibrada de assentamentos humanos e atividades e à falta de governabilidade política (sustentabilidade política), que introduz a sustentabilidade do sistema internacional para manter a paz e estabelecer um sistema de administração do patrimônio comum da humanidade.

O autor apresenta, ainda, critérios de sustentabilidade para cada uma das dimensões mencionadas: “1. Social: alcance de um patamar razoável de homogeneidade social; distribuição de renda justa; emprego pleno e/ou autônomo 
com qualidade de vida decente; igualdade no acesso aos recursos e serviços sociais. 2. Cultural: mudanças no interior da continuidade (equilíbrio entre respeito à tradição e inovação); capacidade de autonomia para elaboração de um projeto nacional integrado e endógeno (em oposição às cópias servis dos modelos alienígenas); autoconfiança combinada com abertura para o mundo. 3. Ecológica: preservação do potencial do capital natureza na sua produção de recursos renováveis; limitar o uso dos recursos não-renováveis. 4. Ambiental: respeitar e realçar a capacidade de autodepuração dos ecossistemas naturais. 5. Territorial: configurações urbanas e rurais balanceadas (eliminação das inclinações urbanas nas alocações do investimento público); melhoria do ambiente urbano; superação das disparidades inter-regionais; estratégias de desenvolvimento ambientalmente seguras para áreas ecologicamente frágeis (conservação da biodiversidade pelo ecodesenvolvimento). 6 . Econômico: desenvolvimento econômico intersetorial equilibrado; segurança alimentar; capacidade de modernização contínua dos instrumentos de produção; razoável nível de autonomia na pesquisa científica e tecnológica; inserção soberana na economia internacional. 7. Política (nacional): democracia definida em termos de apropriação universal dos direitos humanos; desenvolvimento da capacidade do Estado para implementar o projeto nacional, em parceria com todos os empreendedores; um nível razoável de coesão social. 8. Política (internacional): eficácia do sistema de prevenção de guerras da ONU, na garantia da paz e na promoção da cooperação internacional; um pacote Norte-Sul de co-desenvolvimento, baseado no princípio de igualdade (regras do jogo e compartilhamento da responsabilidade de favorecimento do parceiro mais fraco); controle institucional efetivo do sistema internacional financeiro e de negócios; controle institucional efetivo da aplicação do Princípio da Precaução na gestão do meio ambiente e dos recursos naturais; prevenção das mudanças globais negativas; proteção da diversidade biológica (e cultural); e gestão do patrimônio global, como herança comum da humanidade; sistema efetivo de cooperação científica e tecnológica internacional e eliminação parcial do caráter de commodity da ciência e tecnologia, também como propriedade da herança comum da humanidade" (SACHS, 2000, p. 85-88). 
Para BARBIERI (1997, p. 16), o que vem sendo chamado de desenvolvimento sustentável se refere a uma "nova maneira de perceber as soluções para os problemas globais, que não se reduzem apenas à degradação do ambiente físico e biológico, mas que incorporam dimensões sociais, políticas e culturais, como a pobreza e a exclusão social". Esse conceito sugere um legado permanente de uma geração a outra, para que todas possam ter suas necessidades atendidas, incorporando o significado de manutenção e conservação eterna dos recursos naturais, desafio que exige avanços científicos e tecnológicos capazes de ampliar permanentemente a capacidade de utilização, recuperação e conservação desses recursos, bem como novos conceitos de necessidades humanas, de modo a reduzir as pressões da sociedade sobre eles.

O conceito de sustentabilidade é apresentado por BELLEN (2005) a partir de análises feitas em cinco dimensões: econômica, social, ambiental, geográfica e cultural. A sustentabilidade na perspectiva econômica se refere à manutenção do capital em todas as suas formas, ou seja, natural, humano e social, abrangendo sua alocação e distribuição eficientes dentro de uma escala apropriada. A tendência de monetarização da sustentabilidade feita na abordagem econômica, entretanto, afirma o autor, encontra sérias dificuldades, diante da crescente percepção da existência de aspectos não monetários que devem ser considerados para realmente se alcançar a sustentabilidade, dentre os quais, aspectos demográficos, sociais e ambientais. $\mathrm{Na}$ perspectiva social, a sustentabilidade enfatiza a dimensão humana, tendo como maior preocupação o bem-estar humano e os meios utilizados para melhorar a qualidade de vida do ser humano. Segundo essa abordagem, a riqueza, embora importante, é apenas parte do quadro geral da sustentabilidade. A sustentabilidade na dimensão ambiental, por sua vez, é expressa pela capacidade de utilização do capital natural e os impactos das atividades humanas sobre o meio ambiente, visto que, sendo os recursos naturais a base fundamental sobre a qual se assenta a espécie humana, sua deterioração deve ser mantida em um nível mínimo. Segundo a abordagem geográfica, a sustentabilidade pode ser obtida por meio de uma melhor distribuição dos assentamentos humanos e das atividades econômicas, nos contextos ruralurbano, com proteção da diversidade biológica e melhoria da qualidade de vida, 
enquanto na dimensão cultural, a sustentabilidade está relacionada à modernização sem o rompimento da identidade cultural em contextos espaciais específicos.

A expressão desenvolvimento sustentável, afirmam PHILIPPI et. al (2005), significa crescer dentro de padrões de respeito à natureza e em harmonia com ela, como também respeitando os valores e cultura das pessoas e comunidades. Refere-se ao "modelo de crescimento da economia que leva em consideração as possibilidades de exaustão de recursos naturais, as possibilidades de reutilização de produtos ou subprodutos originados desses recursos, o controle de danos que os produtos e resíduos possam provocar no ambiente e as possibilidades de minimizar seus impactos negativos” (p. 666).

A noção de desenvolvimento sustentável, segundo NOBRE (2002), pôs de lado os termos do debate ambiental ocorrido na década de 1970, orientado pela dúvida sobre a contradição entre preocupações ambientais e desenvolvimento. Assim, como resultado de "uma operação diplomática, ideológica e social de grande envergadura" a força da noção de desenvolvimento sustentável está em ter dito que desenvolvimento, no sentido de "crescimento econômico" e meio ambiente, no sentido de "estoque de recursos naturais" (p. 71), não são contraditórios, conseguindo abranger posições de início politicamente inconciliáveis. A constituição do conceito de desenvolvimento sustentável refere-se à estratégia inicial adotada pelo United Nations Development Programme (UNEP) [Programa de Desenvolvimento das Nações Unidas] para institucionalizar a problemática ambiental, "dando-lhe o estatuto de issue de primeiro time na agenda política internacional" (p. 49), proposta essa que sofreu uma severa derrota na Conferência do Rio. A Rio-92, segundo o autor, não deixou de cumprir o papel de proceder à institucionalização da problemática ambiental. Entretanto, a partir daí passou a prevalecer o viés econômico na consideração do desenvolvimento sustentável, com a separação entre negociações de acordos ambientais globais e implementações de projetos de desenvolvimento sustentável de âmbito nacional, passando as negociações destes a se darem majoritariamente no âmbito do Global Environment Facility (GEF) [Programa Ambiental Global] do Banco Mundial.

Atualmente, afirma Nobre, embora existam abordagens alternativas que a contestam, a concepção hegemônica de desenvolvimento sustentável revela a 
prevalência do econômico e de instituições internacionais dominadas pelos países desenvolvidos na institucionalização da problemática ambiental, estando acoplada à "pauta nociva” da chamada globalização econômica.

A despeito da existência de diferentes abordagens conceituais de desenvolvimento sustentável, que variam conforme as diversas dimensões ou bases ideológicas em que são construídas, não havendo, ainda, um conceito claro e universalmente aceito, será utilizado como referencial teórico deste trabalho o conceito de desenvolvimento sustentável trazido pelo Relatório Brundtland, uma vez que se trata do conceito mais conhecido e aceito mundialmente, além de se fundamentar na harmonização de objetivos sociais, ambientais e econômicos, defendida como necessária pela maioria dos autores para sua efetivação.

No tópico seguinte destacamos a importância da existência de políticas públicas ambientais adequadas à promoção do desenvolvimento sustentável (2.2.1.), abordando seus principais instrumentos (2.2.2.), bem como a política ambiental brasileira (2.2.3.). Na sequiência, é mencionada a necessidade de uma gestão ambiental eficiente para a implementação dessas políticas (2.2.4.), ressaltando-se a gestão ambiental no setor industrial como parte fundamental desse processo (2.2.5.) e, por último, são mencionados alguns dos principais sistemas de gestão ambiental utilizados por esse setor (2.2.6.).

\subsection{POLÍTICAS PÚBLICAS AMBIENTAIS E GESTÃO AMBIENTAL}

\subsubsection{Políticas Públicas Ambientais}

O processo político de conscientização ambiental em nível global, marcado pelos acontecimentos mencionados no item 2.1.1., intensificou os debates em torno da relação entre meio ambiente e desenvolvimento, em especial a partir da realização da Conferência de Estocolmo, em 1972, até chegarmos ao conceito atual de desenvolvimento sustentável, contribuindo, também, para uma alteração das políticas

públicas governamentais de enfrentamento da questão ambiental que, segundo 
BARBIERI (2006), até a década de 1970, eram quase exclusivamente de caráter corretivo, ou seja, os governos enfrentavam os problemas ambientais somente após o surgimento destes, resultando em ações fragmentadas, apoiadas em medidas pontuais, pouco integradas e de baixa eficácia.

O Relatório Nosso Futuro Comum, elaborado pela Comissão Brundtland, em 1987, já advertia que os objetivos do desenvolvimento sustentável deveriam integrar todas as políticas e planejamento dos diversos setores do governo, com a integração da economia e da ecologia nos processos decisórios e legislativos, sendo importante, ainda, o fortalecimento da capacidade e das funções das agências de proteção ambiental e de administração de recursos.

No tocante às atividades industriais, o relatório afirma que é importante o estabelecimento de metas, regulamentações, incentivos e padrões ambientais bem definidos para as indústrias, priorizando os problemas de saúde pública ligados à poluição industrial e aos rejeitos perigosos, bem como o aperfeiçoamento das estatísticas ambientais e sua base de dados referentes a essas atividades. As regulamentações que impõem padrões de desempenho uniforme são essenciais para garantir que as indústrias façam os investimentos necessários para assegurar a proteção do meio ambiente, posto que, diante da concorrência entre elas, há limites para o que se pode esperar que façam voluntariamente (CMMAD, 1991).

A consideração do desenvolvimento de qualquer sociedade como sustentável, afirmam PHILIPPI et. al. (2005), está atrelada à maneira como o capital natural (a base de recursos naturais renováveis e não renováveis) e o capital produzido pelo ser humano (tecnologia, capital, conhecimento) se inter-relacionam, as formas de substituição e compensação entre ambos, bem como "a existência de uma política pública ambiental que reconheça essa relação em todos os setores e por fim que ela seja regida por várias disciplinas com implicações no meio natural e no antrópico" (p. 793).

Sem adentrar nos aspectos históricos do surgimento e evolução do Estado até chegarmos à concepção atual de Estado Social, o principal papel do Estado, em sua conformação conceitual, que permanece válida para a atualidade, é o de promover o bem comum. Trata-se do denominado Estado de Bem-Estar social, no qual cabe ao Estado promover a melhoria das condições de vida da população, reduzindo as 
diferenças e eliminando os motivos de conflitos, pelo desenvolvimento econômico homogêneo, produzindo, como conseqüência, outros benefícios, de caráter material ou não, criando-se uma situação generalizada de bem-estar, fundamentada na garantia de liberdade e igualdade para todos. É a afirmação da 'sociedade de todos' (DALLARI, 2001).

No momento atual, em que a promoção do desenvolvimento sustentável passou a ser mais que uma aspiração - uma necessidade do ser humano - a realização do bem comum ou do bem-estar social envolve, forçosamente, a preservação e conservação do meio ambiente. Portanto, hoje, a busca de um convívio harmonioso e justo do elemento humano e do elemento natureza, proporcionando às comunidades humanas um ambiente de qualidade passou a ser um dever do Estado. Nesse aspecto, a existência de políticas públicas ambientais adequadas, com a integração da questão ambiental em todos os setores do governo, constitui condição necessária para a materialização do desenvolvimento sustentável (PHILIPPI e BRUNA, 2004).

BARBIERI (2006) define política pública ambiental como "o conjunto de objetivos, diretrizes e instrumentos de ação de que o Poder Público dispõe para produzir efeitos desejáveis sobre o meio ambiente" (p. 60).

Para PHILIPPI e BRUNA (2004), política pública "é o conjunto de diretrizes estabelecido pela sociedade, por meio de sua representação política, em forma de lei, visando à melhoria das condições de vida dessa sociedade” (p. 691). Quando esse conjunto de diretrizes está relacionado com a proteção do meio ambiente, tem-se a política pública ambiental.

Pelo menos três premissas devem ser observadas para a construção de políticas públicas sustentáveis, as quais, segundo MERICO (2001) constituem a própria essência da sustentabilidade. A primeira delas é a equidade intrageração, uma vez que não é possível construir uma relação equilibrada com a natureza em uma sociedade com profundos desequilíbrios sociais. A segunda premissa a ser observada é a equidade intergeração, pela qual, por motivo de justiça, as políticas públicas devem garantir a estabilidade dos ativos ambientais através dos tempos, para que as gerações futuras recebam uma herança pelo menos igual, ou superior, à herança que nossas gerações receberam. Por último, é preciso considerar sempre as incertezas do conhecimento humano sobre a dinâmica dos processos naturais e a irreversibilidade 
de muitas das alterações produzidas pelas atividades antrópicas. Assim, conforme o autor, no processo de tomada de decisões, é necessário considerar a capacidade de suporte e o nível de resiliência (possibilidade de retornar ao estado anterior depois de sofrer pressão) na relação entre sociedade e ambiente natural, bem como adotar a precaução quanto a quê tipos de alterações podem ser aceitas e quais representam risco para a sociedade.

Contudo, não basta a construção de um aparato legal e institucional. É necessário criar condições para a implementação das políticas públicas ambientais que venham a ser definidas. Para alcançar uma implementação consistente, SOUZA (2000) argumenta que a política ambiental deve apresentar os seguintes elementos: os objetivos e pressupostos, que estabelecem 'o que' deve ser perseguido; os instrumentos, que são os meios ou o 'como' implementar a política; e a definição dos aspectos institucionais, que define os atores responsáveis pela implementação ou 'quem' implementa a política.

BARBIERI (1997) afirma que "a eficácia de uma política pública ambiental dependerá sempre do grau de importância que a sociedade atribui às questões ambientais. Dependerá também dos seus instrumentos e da maneira como eles se articulam entre si e com as demais políticas públicas, notadamente as de ciência e tecnologia, energia, transportes, saneamento básico, educação, ocupação do solo e recursos hídricos" (p. 75), sendo que, a longo prazo, somente a educação ambiental será capaz de produzir os frutos necessários à efetiva implementação do desenvolvimento sustentável.

A participação efetiva da população na elaboração de uma política pública, afirma (MACHADO, 2003), além de envolver um princípio democrático, representa a construção de uma nova forma de encarar a gestão de recursos públicos caros e escassos, tais como os recursos naturais, envolvendo o pressuposto de que a aceitação é maior quando existe participação em todo o processo de gestão de uma política ou processo. Estando envolvida na tomada de decisão, a população estará mais comprometida com a sua implantação, tornando-se agente e não paciente desta.

Para SÁNCHEZ (1998), as políticas públicas ambientais são vitais, ainda, para a mudança de comportamento das corporações no trato das questões ambientais, exercendo mesmo um papel central na melhoria do desempenho ambiental das 
empresas. O Poder Público, afirma o autor, não age sozinho. Por trás das políticas públicas estabelecidas estão o amplo contexto de degradação ambiental global e a pressão pública. As políticas públicas e regulamentações, inclusive aquelas estabelecendo graves punições aos degradadores, tais como penas de prisão por danos tidos como crimes ambientais, criam a necessidade de melhorias tecnológicas, bem como de implementação de sistemas de gestão ambiental eficientes, favorecendo a resposta das indústrias ao desafio da sustentabilidade.

O conceito de política pública ambiental adotado como referencial teórico neste trabalho, dada à sua abrangência, é aquele trazido por PHILIPPI e BRUNA (2004) como o conjunto de diretrizes estabelecido pela sociedade, por meio de sua representação política, para a proteção do meio ambiente e, conseqüentemente, das condições de vida dessa mesma sociedade.

\subsubsection{Instrumentos de Política Pública Ambiental}

A escolha de instrumentos adequados de política pública ambiental é um dos aspectos fundamentais que irá determinar a eficácia desta. Inúmeros são os fatores que devem ser levados em consideração, fato que torna a questão bastante complexa, abarcando desde as características dos problemas ambientais, o contexto socioeconômico em que será implementada e o sistema político nacional, assim como as tendências internacionais de política ambiental. A eficácia de um instrumento de política do meio ambiente, portanto, não depende exclusivamente de suas características, mas também das circunstâncias em que é aplicado. Fundamental é que tenham como objetivo a mudança de uma trajetória de adoção de políticas de caráter corretivo dos problemas ambientais para políticas de caráter preventivo (ALMEIDA, 1998).

BARBIERI (2006) afirma que os instrumentos de política pública ambiental podem ser explícitos ou implícitos, sendo os primeiros criados para a obtenção de efeitos ambientais benéficos específicos, enquanto os segundos alcançam esses benefícios por via indireta. $\mathrm{O}$ autor cita, como exemplo destes últimos, investimentos em educação, que tornam a população mais consciente dos problemas ambientais, aumentando a cobrança dos cidadãos sobre o desempenho ambiental das empresas e 
dos órgãos ambientais governamentais. Entretanto, em geral, quando se fala em instrumento de política pública ambiental, está-se referindo aos instrumentos explícitos que, segundo Barbieri, podem ser classificados em três grandes grupos: comando e controle, econômicos e outros. Essa classificação, apresentada abaixo, foi adotada como referencial teórico deste trabalho.

Tabela 1 - Instrumentos de Política Pública Ambiental - Classificação e Exemplos

\begin{tabular}{|c|c|}
\hline GÊNERO & ESPÉCIES \\
\hline $\begin{array}{l}\text { COMANDO } \\
\text { E } \\
\text { CONTROLE }\end{array}$ & $\begin{array}{l}\text { - Padrão de emissão } \\
\text { - Padrão de qualidade } \\
\text { - Padrão de desempenho } \\
\text { - Padrões tecnológicos } \\
\text { - } \text { Proibições e restrições sobre produção, comercialização e } \\
\text { - Licenciamento ambiental } \\
\text { - Zoneamento ambiental } \\
\text { - Estudo prévio de impacto ambiental }\end{array}$ \\
\hline ECONÔMICO & $\begin{array}{l}\text { - Tributação sobre poluição } \\
\text { - Tributação sobre uso de recursos naturais } \\
\text { - Incentivos fiscais para reduzir emissões e conservar } \\
\text { recursos } \\
\text { - Financiamentos em condições especiais } \\
\text { - Criação e sustentação de mercados de produtos } \\
\text { ambientalmente saudáveis } \\
\text { - Permissões negociáveis } \\
\text { - } \text { Sistema de depósito-retorno } \\
\text { - Poder de compra do Estado }\end{array}$ \\
\hline OUTROS & $\begin{array}{l}\text { - Apoio ao desenvolvimento científico e tecnológico } \\
\text { - Educação ambiental } \\
\text { - Unidades de conservação } \\
\text { - Informações ao público }\end{array}$ \\
\hline
\end{tabular}

Fonte: BARBIERI, 2006.

Os instrumentos de comando e controle se caracterizam pela regulação direta do comportamento do poluidor por autoridades governamentais, "limitando ou condicionando o uso de bens, a realização de atividades e o exercício de liberdades individuais em benefício da sociedade como um todo". Manifesta-se por meio de 
proibições, restrições e obrigações impostas aos indivíduos e organizações, autorizadas por normas legais, sob a ameaça de penalidades em caso de desobediência à regra estabelecida, que pode ser aplicada em processos administrativos ou judiciais. Trata-se do exercício do poder de polícia dos entes estatais (BARBIERI, 2006, p. 61).

Dentre os instrumentos de regulação direta mais conhecidos estão aqueles que estabelecem padrões ou níveis máximos de concentração aceitáveis de poluentes, os quais, conforme o autor, podem ser de três tipos: padrão de qualidade ambiental; padrão de emissão; e padrão ou estágio tecnológico. $\mathrm{O}$ padrão de qualidade ambiental se refere aos níveis máximos de concentração admitidos para os poluentes no meio ambiente, em regra segmentado em ar, água e solo. Já os padrões de emissão se referem aos limites máximos de lançamentos de poluentes individualizados por fonte, enquanto o padrão tecnológico diz respeito à restrição pelo Poder Público das opções tecnológicas disponíveis, direcionando a escolha de equipamentos, instalações e práticas operacionais e administrativas, acabando por promover uma certa uniformização entre os agentes produtivos que atuam em um mesmo segmento. Também se insere nessa categoria o controle de produtos, que vai desde o estabelecimento de normas para produtos cujo processo de produção ou consumo final acarrete alguma forma de poluição, até proibições de produção, comercialização ou uso de produtos. Tem-se, ainda, o controle do uso de recursos naturais por meio da fixação de cotas de produção, comercialização ou utilização de materiais ou recursos, bem como o controle espacial de atividades por meio dos instrumentos de zoneamento ambiental e licenciamento ambiental para obras ou atividades potencialmente poluidoras.

Os instrumentos econômicos objetivam induzir o próprio poluidor a tomar a iniciativa de reduzir seus níveis de poluição, por meio de medidas que representem benefícios ou custos adicionais para ele, permitindo-lhe uma certa flexibilidade na escolha da maneira e do tempo que melhor lhe convier economicamente responder a esses estímulos (ALMEIDA, 1998).

Esses instrumentos podem ser de dois tipos: fiscais e de mercado. Entre os primeiros estão os tributos e os subsídios. Nestes ocorre renúncia ou transferência de receita dos entes estatais em benefício dos agentes privados para que estes reduzam 
seus níveis de degradação ambiental, por meio de isenções, reduções ou diferimento de impostos e concessão de financiamentos em condições especiais. Nos tributos ambientais há a transferência de recursos dos agentes privados para o setor público em decorrência de algum problema ambiental, por meio da cobrança de impostos e encargos ambientais, especialmente taxas ou tarifas. Os tributos mais conhecidos são aqueles que se referem à tributação sobre emissões, sobre a utilização de serviços públicos de coleta e tratamento de efluentes, sobre os preços de produtos que geram poluição no seu processo de produção ou ao serem utilizados pelo consumidor final, bem como a tributação baseada em alíquotas diferenciadas, conforme o grau de impacto ambiental dos produtos, gravando aqueles mais poluentes (BARBIERI, 2006).

Os tributos ambientais atendem ao princípio do poluidor-pagador que impõe ao Estado o dever de imputar ao poluidor o custo social da poluição por ele gerada. Esse princípio foi agasalhado pela Declaração do Rio, de 1992, que em seu Princípio 16, dispõe que "as autoridades nacionais devem fomentar a promoção da internalização dos custos ambientais e o uso de instrumentos econômicos, tendo em conta o critério de que o poluidor deve, em princípio, arcar com os custos da poluição, levando em conta o interesse público, sem distorcer o comércio e os investimentos internacionais" (UNITED NATIONS, 1992).

O princípio do poluidor-pagador, segundo MILARÉ (2000), se inspira na teoria econômica de que os custos sociais externos que acompanham o processo produtivo, dentre os quais se insere a degradação ambiental, tida como uma externalidade negativa, devem ser internalizados. De acordo com esse princípio, os agentes econômicos, ao elaborarem os custos de produção, devem levar em conta o custo resultante dos danos ambientais que afetam a toda a sociedade e, conseqüentemente, assumi-los. O principal objetivo do princípio é evitar o dano ao meio ambiente, induzindo um comportamento ambiental preventivo por parte dos agentes privados, bem como, conforme BARBIERI (2006), arrecadar receita para custear os serviços ambientais, a fim de evitar que os prejuízos causados pelos poluidores recaiam sobre a sociedade.

Os instrumentos econômicos de mercado, que podem ser criados e administrados no âmbito governamental, consistem em transações efetuadas entre 
agentes privados em mercados regulados pelo governo. ALMEIDA (1998) afirma que, artificialmente, cria-se um "mercado para poluição", no qual é permitido "comprar ou vender direitos (cotas) de poluição de fato ou potencial; transferir riscos associados a danos ambientais para terceiros; e vender refugos/resíduos do processo de fabricação" (p. 46). Dentre esses instrumentos estão o seguro ambiental obrigatório e a manutenção e/ou criação pelo governo de mercados para resíduos industriais potencialmente rentáveis, sustentado por intermédio de preço mínimo garantido ou subsídio, no caso do preço de mercado ficar abaixo de certo valor.

O seguro ambiental, conforme FONSECA JR e CANTARINO (2004), constitui importante instrumento econômico de mercado, na medida em que incentiva as empresas a posturas pró-ativas nas questões ambientais. Controlando todos os processos de sua produção e fornecimento, os custos na contratação do seguro ambiental poderão ser reduzidos, em razão da redução dos riscos ambientais suportados pela seguradora. Na medida em que as seguradoras, ao acompanharem as atividades dos empreendimentos segurados, com base no direito-dever da seguradora de fiscalizar o objeto do contrato, verificarem que o empreendimento possui um bom sistema de gestão ambiental implementado, no qual toda a cadeia produtiva está ancorada na proteção e segurança do meio ambiente, terão o risco de ocorrência de sinistros reduzido, ocasionando um custo menor na contratação do seguro. Os autores apontam como vantagens do seguro ambiental: incentiva comportamentos mais adequados em face da proteção do meio ambiente, por meio da aplicação de prêmios de seguro diferenciados para agentes mais ou menos merecedores de confiança; reduz drasticamente a carga burocrática e os meios necessários por parte das entidades competentes do Estado, tanto para o controle prévio, quanto para a fiscalização das atividades, com resultados equivalentes; reduz a necessidade de recorrer ao Poder Judiciário em caso de sinistro, com as vantagens inerentes em termos de rapidez e eficiência.

Também é o caso das licenças de poluição negociáveis, também denominadas de créditos de redução de emissão, sistema pelo qual o Estado determina o nível máximo de poluição permitido em uma região ou para um certo conjunto de indústrias, em termos de um poluente específico, e divide esse total em cotas que assumem a forma jurídica de direitos/licenças alocadas ou leiloadas entre os agentes 
envolvidos. Assim, reduzindo seus níveis de emissão o produtor estabelecido pode comercializar seu crédito remanescente ou utilizá-lo para ampliar sua produção. BARBIERI (2006) afirma que para que esse instrumento alcance a eficácia desejada sempre haverá necessidade da fixação de padrões de emissão pelo governo, bem como o estabelecimento de metas de redução progressiva do nível geral de poluição, aliados a uma atuação eficaz do órgão governamental ambiental para medir a poluição emitida pelas fontes.

Os sistemas de depósito-retorno são outra espécie de instrumento econômico, segundo o qual sobre o preço final do produto potencialmente poluidor incide uma sobretaxa, que é devolvida ao consumidor quando este retorna esse produto aos pontos de coleta, armazenagem, tratamento ou reciclagem. É o que ocorre, por exemplo, na recuperação de garrafas de bebidas ou outros vasilhames. Outro exemplo é o que vem ocorrendo na Suécia e Noruega, onde, conforme Barbieri, foram criados sistemas de depósitos para a compra de automóveis novos, que serão devolvidos ao final de sua vida útil, desde que entregues em locais predeterminados.

$\mathrm{O}$ autor defende que esse tipo de instrumento pode ser incentivado por leis que estabeleçam a co-responsabilidade do produtor sobre seus produtos mesmo após o consumo, ou seja, durante todo o seu ciclo de vida, transferindo a responsabilidade física e financeira da gestão dos resíduos das autoridades governamentais e do contribuinte para o produtor. Estímulos à criação de mercados para os materiais recicláveis, auxílio às empresas na criação de capacidade para reciclar, estímulos à adoção de produção mais limpa, dentre outros, também constituem importantes instrumentos econômicos de políticas públicas ambientais.

Vantagens e desvantagens dos dois tipos de instrumentos de política pública ambiental são apontadas por diversos autores, dentre os quais aqueles acima citados, apresentando pontos em comum, que serão abordados, resumidamente, a seguir.

Quanto aos instrumentos de comando e controle, costuma-se apontar como desvantagens que, além de dependerem de um aparato institucional dispendioso para o Estado, tendem a gerar uma atitude de acomodação das empresas na medida em que as exigências do poder público são atendidas. Aponta-se, ainda, que não consideram as distintas situações dos agentes individuais para cumprir a obrigação, sendo ineficientes economicamente; podem sofrer influência de determinados grupos 
de interesse; e tendem a perpetuar a estrutura de mercado existente. No entanto, teriam como principal vantagem uma elevada eficácia ecológica, que garante amplo apoio da opinião pública e influencia a decisão dos responsáveis pela elaboração de políticas públicas.

PORTER e LINDE (1995), entretanto, defendem que regulamentações ambientais adequadas podem estimular o surgimento de inovações, melhorando a competitividade, pelo uso mais eficiente dos recursos naturais e redução dos custos ambientais, assim como pela criação de novos produtos e de produtos com melhor qualidade. Os autores afirmam que, diante da falta de consciência dos consumidores sobre os custos da poluição, com os quais acabam arcando, somada ao fato de que o setor empresarial ainda é inexperiente e incapaz de enfrentar as questões ambientais de maneira criativa, a regulamentação é necessária pelas seguintes razões principais: “1) cria pressões que motivam as empresas a inovar; 2) melhora a qualidade ambiental nos casos em que a inovação e as melhorias na produtividade não compensam o custo total da conformidade; 3) alerta e educa as empresas a respeito de prováveis ineficiências de recursos e de áreas potenciais para melhorias tecnológicas; 4) aumenta a probabilidade de que as inovações de produtos e processos sejam mais amigáveis ao meio ambiente; 5) cria demanda pelo aprimoramento ambiental até que as empresas e os clientes sejam capazes de perceber e mensurar as ineficiências dos recursos como fonte de poluição; 6) ajuda a nivelar o campo do jogo durante o período de transição para soluções ambientais baseadas na inovação, assegurando que nenhuma empresa será capaz de ganhar posição por não efetuar os investimentos ambientais" (p. 128).

Os instrumentos econômicos, teoricamente, seriam mais eficientes que os de comando e controle por gerarem custos menores do que estes para as empresas, além de proporcionarem estímulos permanentes para que as empresas deixem de gerar poluição, induzindo um comportamento mais dinâmico por parte dos agentes privados e contribuindo para estimular atividades de P\&D (Pesquisa e Desenvolvimento). Apontam-se, ainda, como vantagens, sua flexibilidade e seletividade. Entretanto, também apresentam desvantagens, uma vez que, na prática, o estabelecimento de tributos nem sempre se transforma em incentivos para mudar o comportamento de empresários e consumidores, podendo inviabilizar os negócios, 
caso sejam muito elevados, ou não provocar as mudanças esperadas, se forem baixos. Também demandam custos elevados, diante das diferentes características de cada setor econômico e acabam tendo muito mais uma função arrecadadora que estimuladora de comportamentos ambientais desejáveis. O mesmo ocorre com os subsídios, muito criticados por representarem uma concessão de prêmios aos poluidores, ferindo o princípio do poluidor-pagador (BARBIERI, 2006).

Para MOTTA e MENDES (2001), mecanismos de instrumentos econômicos devem ser criados, uma vez que proporcionam melhoria ambiental e econômica esta em face da maior eficiência produtiva e equidade - por orientarem as atividades produtivas a revelarem seus custos ambientais e determinarem suas atividades de produção de forma mais ajustada ao uso racional e eficiente dos recursos naturais disponíveis. Os mecanismos de comando e controle, conforme os autores, devem ser ajustados com os instrumentos econômicos, assim como deve-se conciliar o objetivo de geração de receita com o de indução à mudança do padrão de uso e consumo dos recursos naturais.

MERICO (2001) menciona, ainda, instrumentos que denomina de voluntários, ou seja, aqueles "utilizados pelo poder público para induzir os processos de transformação da sociedade por meio das mudanças comportamentais, mudanças de mercado, fortalecimento da sociedade civil, mudanças produtivas" (p. 259), denominados por alguns autores de instrumentos institucionais. Entre os instrumentos voluntários cita a educação ambiental, atividades direcionadas ao público interessado em aprofundar conceitos e entender melhor as questões ambientais, apoio às lutas das entidades comunitárias, formação de novas organizações que tenham o ambiente como interesse, a certificação ambiental, a coleta seletiva de resíduos domiciliares ou de resíduos especiais, bem como a Agenda 21 local, uma vez que nesta procura-se sistematizar os consensos sociais em torno da sustentabilidade. A definição de indicadores ambientais que permitam a avaliação constante do nível de sustentabilidade do processo econômico-social também pode se constituir em uma estratégia eficaz de política ambiental. O objetivo seria influenciar a atividade econômico-social de maneira que esta não excedesse as metas fixadas pelos indicadores. 
PHILIPPI JR e BRUNA (2004) acrescentam os denominados instrumentos de controle social, alicerçados no princípio jurídico da prevenção e fundados na gestão participativa, agrupando-os em avaliação de impacto ambiental (AIA), ações do Ministério Público, dos órgãos colegiados (conselhos, comitês) e das organizações da sociedade civil (Organizações não governamentais (ONGs), sindicatos, movimentos sociais, igrejas, associações civis).

Uma política ambiental consistente, conforme BARBIERI (2006), não pode prescindir de quaisquer instrumentos, devendo se valer de todos aqueles possíveis, de modo a que seja eficiente na prevenção de danos, sem prejudicar a competitividade das empresas, especialmente em termos internacionais. No longo prazo, investimentos em educação ambiental e no desenvolvimento científico e tecnológico são eficazes instrumentos indiretos, não só para a melhoria das práticas empresariais, como também para a mudança de comportamento de toda a população na sua relação com o meio ambiente. Incentivos para o desenvolvimento de novos produtos e processos mais eficientes no uso de recursos naturais e na redução dos níveis de emissão são fundamentais, assim como promover a conscientização da população mundial, proporcionando-lhes conhecimentos sobre o meio ambiente, a fim de que possam atuar individual e coletivamente na busca de soluções para os problemas atuais e na prevenção de novos problemas.

Em face do caráter multidisciplinar das questões ambientais, a eficácia dos instrumentos explícitos de políticas públicas ambientais depende, ainda, de sua integração nas políticas públicas de todos os demais setores do governo: economia, agricultura, saneamento, saúde, habitação, energia, transportes, dentre outros. A coerência e interação entre os diversos instrumentos de políticas públicas, por meio de uma gestão adequada, pode determinar o sucesso ou insucesso da implementação do desenvolvimento sustentável.

\subsubsection{A Política Pública Ambiental Brasileira}

No Brasil, a preocupação com o meio ambiente esteve voltada, inicialmente, para a proteção dos recursos naturais, sendo essa fase marcada pelo surgimento de regulamentações voltadas para a forma de apropriação desses recursos, por meio de 
gestões setoriais. Como exemplos de políticas públicas dessa fase podem ser citadas as promulgações, na década de 1930, do Código de Caça, do Código Florestal, do Código de Minas e do Código de Águas.

Com a consolidação do processo industrial, especialmente em meados da década de 1960, levando ao aumento da degradação ambiental, a que se somaram o aumento da conscientização pública, a preocupação da mídia e o aumento do conhecimento científico e tecnológico, as políticas públicas ambientais no Brasil passaram a enfocar o controle da poluição ambiental, porém ainda dentro de uma abordagem segmentada do meio ambiente (BARBIERI, 2006).

PHILIPPI JR et. al (2005) afirmam que a evolução das políticas públicas no Brasil não ocorreram de maneira estanque, com data de início, meio e fim, havendo sinergismos de enfoques, evolução paralela e políticas mistas em um mesmo período. Nesse caminho, acabaram evoluindo para a abordagem do planejamento territorial, levando ao entendimento do meio ambiente a partir de conceitos regionais, surgindo daí os conceitos de zoneamento, áreas críticas de poluição, regiões metropolitanas, mananciais, dentre outros.

Sob esse enfoque foram promulgadas importantes legislações no país, tais como a Lei 6.7662/76 sobre parcelamento do solo urbano; a Lei 6.830/80, que estabelece as diretrizes básicas para o zoneamento industrial nas áreas críticas de poluição; e a Lei 6.902/81, que dispõe sobre a criação de reservas ecológicas e áreas de proteção ambiental.

Foi, entretanto, a partir da Lei Federal no 6.938, de 31 de agosto de 1981, que estabeleceu a Política Nacional de Meio Ambiente e instituiu o Sistema Nacional de Meio Ambiente, que se pôde contar com uma base legal mais consistente para a execução de políticas públicas ambientais no país. Essa norma procura integrar as ações governamentais dentro de uma abordagem sistêmica, segundo conceitos mais modernos de administração pública e privada, embora, conforme adverte MILARÉ (2000), esse planejamento integrado das políticas públicas ainda não exista no Brasil, "mercê da excessiva setorização e verticalização dos diferentes Ministérios. A isso acresce a inexistência de efetivas definições políticas por parte dos partidos políticos e dos governos, em geral" (p. 267-268). 
A política nacional de meio ambiente estabelecida pela Lei 6.938/81 tem como objeto a preservação, melhoria e recuperação da qualidade ambiental propícia à vida, com a finalidade de assegurar, no país, as condições adequadas ao desenvolvimento socioeconômico, aos interesses da segurança nacional e à proteção da dignidade da vida humana (art. $2^{\circ}$, "caput").

$\mathrm{O}$ art. $4^{\circ}$ da norma enumera os objetivos dessa política, os quais, conforme SILVA (2000), constituem metas concretas a serem realizadas na execução da política ambiental, como condição para a efetivação do objeto e da finalidade por ela perseguidos. Dentre esses objetivos, destaca-se a compatibilização do desenvolvimento sócio-econômico com a preservação da qualidade do meio ambiente e do equilíbrio ecológico (Inc. I), pela qual o país assume a política do equilíbrio, que importa em utilização sustentada dos recursos ambientais e uso racional dos recursos naturais, com garantia de permanência dos renováveis. Os outros objetivos são: definição de áreas de proteção ambiental; estabelecimento de padrões de qualidade ambiental; desenvolvimento de pesquisas e tecnologias adequadas ao uso e manejo dos recursos ambientais; divulgação de dados e informações ambientais; conscientização pública; preservação e restauração dos recursos ambientais para que estejam permanentemente disponíveis; e, por último, a imposição aos poluidores e predadores da obrigação de recuperar e/ou indenizar os danos causados, bem como, ao usuário, da contribuição, como forma de compensação, pela utilização de recursos ambientais com fins econômicos (Incs. II a VII).

A Lei 6.938/81 exige que as diretrizes da política ambiental sejam implementadas por meio de planos, programas e projetos. A exigência de planos, segundo Silva, é especialmente importante por vincular "a orientação preservacionista do meio ambiente aos planos de ordenação territorial e de desenvolvimento econômico e social, que cabe à União elaborar e executar, por força dos arts. 21, IX, e 174, § 1º, ambos da Constituição Federal (p. 194).

A Constituição Federal de 1988, aliás, tratou da matéria em termos amplos e modernos. Além de dedicar um capítulo específico ao meio ambiente, inserido no título da "Ordem Social” (Capítulo VI do Título VIII), a questão permeia todo o seu texto, correlacionada com os temas fundamentais da ordem constitucional, em razão 
do conteúdo multidisciplinar da matéria. Um dos principais avanços da Constituição em relação à tutela ambiental foi a inserção da defesa do meio ambiente como um dos princípios da ordem econômica brasileira, significando que a propriedade privada deixa de cumprir sua função social, aspecto elementar para sua garantia constitucional, quando se insurge contra o meio ambiente (MILARÉ, 2000).

A base normativa do direito do ambiente é dada pelo art. 225, da Constituição Federal, com seus parágrafos e incisos, que define o meio ambiente ecologicamente equilibrado como direito de todos, atribuindo-lhe a natureza de bem de uso comum do povo e essencial à sadia qualidade de vida, impondo responsabilidade compartilhada ao cidadão e ao Poder Público pela sua defesa e preservação. SILVA (2000) afirma que o dispositivo compreende três conjuntos de normas. O primeiro aparece no "caput", onde se inscreve a "norma-princípio" ou "norma-matriz", reveladora do direito de todos ao meio ambiente ecologicamente equilibrado. $\mathrm{O}$ segundo encontra-se no $\S 1^{\circ}$, com seus incisos, que estatui os instrumentos de garantia da efetividade do direito enunciado no "caput" do artigo, conferindo ao Poder Público os princípios e instrumentos fundamentais de sua atuação para a garantia daquele direito. $\mathrm{O}$ terceiro vem referido nos $\S \S 2^{\circ}$ ao $6^{\circ}$, caracterizando um conjunto de determinações particulares, em relação a objetos e setores considerados de primordial exigência e urgência a merecer imediata proteção e direta regulamentação constitucional.

A Constituição Federal de 1988 abriu, assim, espaço jurídico e institucional para uma ação cada vez mais intensa do Estado na elaboração e implementação de políticas públicas ambientais, consolidando a Política Nacional do Meio Ambiente, estabelecida pela Lei 6.938/81, que foi recepcionada pela Carta Magna.

Aspecto relevante da Lei 6.938/81 foi a instituição do Sistema Nacional do Meio Ambiente (SISNAMA), constituído pelos órgãos e entidades da União, dos Estados, do Distrito Federal e dos Municípios e pelas Fundações instituídas pelo Poder Público, responsáveis pela proteção e melhoria da qualidade ambiental, que oferece o arcabouço institucional da gestão ambiental no Brasil. Assim, o art. $6^{\circ}$, da norma, estabelece a estrutura político-administrativa de suporte das atividades de gestão ambiental no país. Essa estrutura é formada por um órgão superior, o Conselho de Governo, que nunca chegou a ser constituído; um órgão consultivo e 
deliberativo, o Conselho Nacional do Meio Ambiente (CONAMA); um órgão central, o Ministério do Meio Ambiente, com funções de planejamento, coordenação e supervisão; um órgão federal executor, o Instituto Brasileiro do Meio Ambiente e dos Recursos Naturais Renováveis (IBAMA); órgãos setoriais da administração federal; órgãos seccionais, constituídos pelos órgãos e entidades estaduais legalmente instituídos e incumbidos da proteção ambiental; e órgãos locais, ou seja, órgãos ou entidades municipais incumbidos legalmente da gestão ambiental no âmbito da sua competência e no respectivo território (MILARÉ, 2000).

O SISNAMA "se caracteriza por ser uma proposta de ações integradas e orgânicas dos órgãos ambientais públicos, sejam da União, dos estados ou dos municípios, no controle e no combate à degradação ambiental" (MARTINS et. al., 2001, p. 171), que somente existe e funciona na medida em que os órgãos e entidades que o integram existem e funcionam. Para o funcionamento adequado do SISNAMA, adverte MILARÉ (2000), é fundamental o fluxo de informações, num processo contínuo, que permita a retroalimentação do sistema.

A política ambiental brasileira, tendo como base a Constituição de 1988, afirma ALMEIDA (1998), segue a orientação "comando e controle", sendo empregados quase que exclusivamente instrumentos de regulação direta, revelando uma forte dependência dos recursos públicos para o exercício das ações de regulação e um caráter mais corretivo, que preventivo, concentrando esforços na redução dos níveis de poluição. Enfrenta, ainda, outros problemas, tais como a falta de adequação no plano legal entre a Constituição Federal e as legislações estaduais e municipais, falta de coordenação entre os vários órgãos da área e carência de recursos financeiros e humanos nas agências ambientais, motivo pelo qual a política formulada em termos da legislação não tem sido efetivamente aplicada.

$\mathrm{O}$ art. $9^{\circ}$, da Lei da Política Nacional de Meio Ambiente, enumera doze instrumentos para a execução da norma, dos quais somente alguns poucos estão implementados, destacando-se o estabelecimento de padrões de qualidade ambiental, a avaliação de impactos ambientais, o licenciamento e a revisão de atividades efetivas ou potencialmente poluidoras, a criação de espaços territoriais especialmente protegidos e as penalidades disciplinares ou compensatórias ao não cumprimento das medidas necessárias à preservação ou à correção da degradação ambiental. 
Sem qualquer pretensão de esgotar o tema, dado os limites deste trabalho, cabe aqui tecer alguns breves comentários sobre três desses instrumentos: o estabelecimento de padrões de qualidade ambiental, a avaliação de impactos ambientais, e o licenciamento e a revisão de atividades efetivas ou potencialmente poluidoras.

Os padrões de qualidade e de emissões de poluentes constituem peça fundamental da política ambiental brasileira, prendendo-se, de modo geral, à classificação dos recursos hídricos superficiais, aos aspectos relativos à poluição e à qualidade do ar, ao controle da poluição sonora e à definição das atividades consideradas potencialmente poluidoras. PÜTZ (2006) adverte que a fixação de padrões de emissão é um elemento básico da regulamentação do controle da qualidade do ar, porém não pode ser feita somente com o objetivo de evitar danos ao meio ambiente ou à saúde pública, mas, face ao princípio da prevenção, deve-se exigir a máxima redução possível das emissões, tendo como único limite o estado da arte da tecnologia. A existência de monitoramento adequado, afirma o autor, também é fundamental, uma vez que, se a qualidade do ar não melhora, os padrões de emissão devem ser reduzidos.

A avaliação de impacto ambiental (AIA), de caráter marcadamente preventivo, trata-se de instrumento de planejamento e gestão, tendo por objetivo analisar a viabilidade ambiental de um projeto, programa ou plano, podendo constituir um procedimento associado a alguma forma de processo decisório, como o licenciamento ambiental. Envolve um conjunto de procedimentos, dos quais se destaca o Estudo Prévio de Impacto Ambiental (EPIA), o qual foi introduzido no direito brasileiro pela Lei 6.803, de 02 de julho de 1980, que dispõe sobre as diretrizes básicas para o zoneamento industrial nas áreas críticas de poluição, sendo erigido à categoria de instrumento da política nacional de meio ambiente pela Lei 6.938/81, papel consolidado pela Constituição Federal de 1988 (MILARÉ, 2000). O EPIA consiste em um procedimento analítico-científico realizado por uma equipe multidisciplinar, tendo como objetivo "descrever os impactos ambientais previsíveis em decorrência de obras ou atividades a serem implantadas em determinada área, com sugestões específicas relacionadas a alternativas que sejam consideradas apropriadas para diminuir impactos negativos sobre o meio" (SOUZA, 2000, p. 41). 
O licenciamento ambiental, que pode ou não estar vinculado à elaboração de EPIA, é exigido para a construção, instalação, ampliação e funcionamento de estabelecimentos e atividades utilizadores de recursos ambientais, considerados efetiva ou potencialmente poluidores, bem como aqueles capazes, sob qualquer forma, de causar degradação ambiental (art. 10, da Lei 6.938/81). O processo de licenciamento, que compreende três etapas - licença prévia, licença de instalação e licença de operação - constitui importante instrumento de gestão ambiental, pelo qual a Administração Pública exerce o necessário controle sobre as atividades humanas que interferem no meio ambiente, de forma a compatibilizar o desenvolvimento econômico-social com a preservação do equilíbrio ecológico, uma das principais metas da política nacional do meio ambiente, nos termos do art. $4^{\circ}$, Inc. I, da Lei 6.938/81 (MILARÉ, 2000).

O instrumento da revisão de atividades efetiva ou potencialmente poluidoras, previsto na Lei 6.938/81, apesar de sua importância na busca da melhoria contínua da qualidade ambiental, somente começou a ser regulamentado a partir da edição da Resolução CONAMA 237/97, que em seu art. 18, além de estabelecer diretrizes mínimas, fixou os prazos mínimos e máximos de validade de cada uma das licenças (prévia, de instalação e de operação), atribuindo aos órgãos ambientais dos Estados e municípios a regulamentação específica, de acordo com o tipo de atividade e desempenho ambiental do empreendimento.

No Estado de São Paulo, a matéria foi regulamentada pelo Decreto Estadual $\mathrm{n}^{\text {o }}$ 47.397, de 04 de dezembro de 2002, que estabeleceu prazos de validade da Licença de Operação, variando de 02(dois) até o máximo de 05(cinco) anos, conforme o fator de complexidade do empreendimento (art. 71). Corretamente, a norma prevê, ainda, a renovação da licença dos empreendimentos que já se encontram em operação, devidamente licenciados (art. 71-A).

Importante aspecto a ser ressaltado é a garantia de publicidade e participação pública na formulação e na execução das políticas públicas ambientais, como ocorre nos processos de licenciamento ambiental, bem como na elaboração e discussão do EPIA, que constitui um dos meios pelo qual a coletividade pode atuar diretamente na defesa do meio ambiente. Embora ainda deficiente, as políticas públicas em discussão no Brasil, seguindo o caminho do que vem ocorrendo na história 
contemporânea dos países ocidentais, vêm se encaminhando para a implantação de instituições que contam com a participação da sociedade, encontrando-se superado o modelo anteriormente utilizado que concentrava responsabilidades unicamente nas mãos do Estado. Contudo, conforme adverte MACHADO (2003), o termo 'participação' acomoda-se a diferentes interpretações, devendo-se garantir a efetiva e material participação da sociedade como protagonista de destaque e não como mera espectadora, marginal ao processo de tomada de decisões. A prática política da gestão colegiada e integrada com negociação sociotécnica é uma forma de garantir a efetiva participação da população na formulação e implantação de políticas públicas ambientais. Segundo o autor, isso significa agir visando ao ajuste de interesses entre as propostas resultantes do diagnóstico técnico-científico e das legítimas aspirações e conhecimentos da população que habita um determinado território e os entes do aparelho de Estado.

Outros instrumentos de grande importância no contexto da gestão ambiental, ainda não se encontram efetivamente implementados no Brasil. Dentre eles, podemos mencionar o zoneamento ambiental, que se caracteriza como um plano de desenvolvimento regional ordenador das várias políticas e programas existentes para a área por ele abrangida, por trazer o conhecimento global da área de estudo de forma sistemática (SOUZA, 2000). Mencione-se, ainda, o sistema nacional de informações sobre o meio ambiente, fundamental para orientar o próprio processo de elaboração das políticas públicas ambientais, e os incentivos governamentais à adoção de tecnologias, produtos e processos produtivos mais sustentáveis, ainda incipientes no país.

SILVA (2000) menciona, também, a ordenação dos espaços urbanos como um instrumento dos mais importantes para a política do meio ambiente, visto que a qualidade do meio ambiente urbano "constitui, mesmo, um ponto de convergência da qualidade do meio ambiente natural (água, ar e outros recursos naturais) e da qualidade do meio ambiente artificial (histórico-cultural)", na medida em que objetiva criar condições para o pleno desenvolvimento das funções sociais da cidade e garantir o bem-estar de seus habitantes (p. 201).

A elaboração e implementação de políticas públicas ambientais que promovam efetivamente o desenvolvimento sustentável no país, conforme afirmam 
PHILIPPI JR e BRUNA (2004), somente se tornará realidade à medida que se eleve a preocupação social com os problemas ambientais, com a efetiva conscientização da sociedade civil para que participe de modo ativo e consciente, não apenas cobrando ações governamentais, mas alterando o próprio comportamento, no cumprimento do dever de não poluir que cumpre a todo cidadão.

\subsubsection{Gestão Ambiental Pública}

As soluções propostas para os problemas ambientais não mais se resumem ao estabelecimento de padrões para emissões de poluentes, fiscalização do cumprimento de normas técnicas ou punição daqueles que poluem o meio ambiente. Embora não se possa prescindir dessas medidas, na atualidade, “a gestão passou a ser o operador conceitual através do qual se confrontam os objetivos de desenvolvimento econômico e de organização territorial, bem como aqueles relacionados à conservação da natureza ou à manutenção ou recuperação da qualidade ambiental" (MACHADO, 2003, p. 24).

A gestão ambiental pública é a ação institucional do poder público para a implementação das políticas ambientais. PHILIPPI JR e BRUNA (2004) explicam que o significado etimológico dos vocábulos "gestão" e "ambiental" tem raízes na língua latina. Assim, "gestão" originou-se de "gestioni”, que exprime o ato de gerir, cujo significado é ter gerência sobre, administrar, reger, dirigir. O vocábulo "ambiental", por seu turno, é o adjetivo aplicado para referir-se às coisas do ambiente, tanto construído, quanto natural. As questões ambientais envolvem, portanto, diversas facetas que, conforme os autores, não podem ser tratadas de forma individualizada, uma vez que as diversas áreas que compõem o complexo ambiental estão estreitamente correlacionadas, mantendo um vínculo de relacionamento vital entre si, motivo pelo qual propostas de gestão ambiental devem ser fundamentadas numa integração físico-territorial, social, política, econômica e cultural, capaz de abranger toda essa complexidade. Daí decorre a importância do tratamento multidisciplinar e da visão sistêmica que devem orientar a gestão ambiental. Aquele exige o trabalho de profissionais de diversas áreas atuando de forma articulada e com o envolvimento da sociedade. Esta mostra as muitas inter-relações entre os ambientes 
natural e construído, bem como no interior de cada um deles. Não se pode olvidar, ainda, que a gestão ambiental envolve também a saúde pública e o planejamento territorial, visto ser seu escopo último a promoção da qualidade de vida.

Gestão ambiental, portanto, segundo os autores, "é o ato de administrar, de dirigir ou reger os ecossistemas naturais e sociais em que se insere o homem, individual e socialmente, num processo de interação entre as atividades que exerce, buscando a preservação dos recursos naturais e das características essenciais do entorno, de acordo com padrões de qualidade. O objetivo último é estabelecer, recuperar ou manter o equilíbrio entre natureza e homem" (p. 700). Para que a gestão ambiental seja eficiente é necessário a existência de um conjunto de instrumentos, representados por leis, normas, decretos, regulamentos, programas destinados a solucionar as questões do ambiente. Contudo, não basta a existência desse conjunto. A gestão ambiental somente será eficaz quando esse conjunto de instrumentos se transformar em ações concretas, traduzidas em problemas resolvidos.

A gestão ou administração ambiental, conforme SÁNCHEZ (1994), pode ser discutida em nível empresarial ou de políticas de governo. Neste último caso, "são abordados os instrumentos de política que podem ser aplicados pelas diversas agências governamentais com vistas a melhorar ou prevenir a degradação da qualidade ambiental” (p. 67), tanto de comando e controle, quanto econômicos. De outro lado, são as políticas governamentais, as demandas e pressões da opinião pública, da comunidade e de consumidores, bem como as condições de mercado, que irão determinar os instrumentos e as alternativas de gerenciamento ambiental nas empresas.

Para SOUZA (2000), a gestão ambiental pode ser entendida como o conjunto de procedimentos que visam à conciliação entre desenvolvimento e qualidade ambiental, dado pela observância da capacidade de suporte do meio ambiente e das necessidades identificadas conjuntamente pela sociedade civil e pelo governo. São os instrumentos de política ambiental que estabelecem as ferramentas de ação para a gestão ambiental, estando o planejamento contido no sistema de gestão, o qual deve ser constantemente retroalimentado, a fim de que as diretrizes de gerenciamento possam ser adaptadas à nova realidade verificada, em um processo contínuo e dinâmico. 
O planejamento integra a gestão ambiental que, por sua vez, alimenta as várias etapas daquele, sendo um processo que permite identificar, compreender e classificar situações e problemas, selecionar e implementar ações em prol da otimização e solução destes, assim como o cumprimento de metas. Envolve, ainda, o monitoramento e avaliação das decisões tomadas e ações implementadas, permitindo a adoção das modificações necessárias ao sucesso do planejamento, a fim de que sejam obtidos os resultados esperados (PHILIPPI JR et. al., 2004).

O planejamento, afirma SACHS (2000) é "uma ferramenta indispensável para projetar e promover estratégias de desenvolvimento sustentável” (p. 56).

A gestão ambiental pública, segundo MERICO (2001), depende de três elementos fundamentais para sua existência e eficácia. Em primeiro lugar, um arcabouço jurídico/legal em nível federal, estadual ou municipal, que possibilite o desenvolvimento de ações que conduzam à sustentabilidade. Em segundo lugar, uma estrutura administrativa adequada para a aplicação desse arcabouço jurídico/legal, capaz de motivar a sociedade a adotar padrões de produção, consumo e comportamentos mais sustentáveis. E, por último, são necessários programas e projetos que interfiram na sociedade e na atividade econômica, criando condições para sua evolução.

BARBIERI (2006) conceitua gestão ambiental como "as diretrizes e as atividades administrativas e operacionais, tais como planejamento, direção, controle, alocação de recursos e outras, realizadas com o objetivo de obter efeitos positivos sobre o meio ambiente, quer reduzindo ou eliminando os danos ou problemas causados pelas ações humanas, quer evitando que eles surjam” (p. 19-20). Para esse autor, qualquer proposta de gestão ambiental deve incluir, no mínimo, três dimensões: a dimensão espacial, a dimensão temática e a dimensão institucional. A primeira diz respeito à área na qual as ações de gestão serão aplicadas e se espera que tenham eficácia, que podem ir desde a dimensão global até a dimensão local, setorial, empresarial, etc. A segunda delimita as questões ambientais às quais as ações de gestão se destinam, tais como ar, águas, solo, fauna e flora, etc. A terceira dimensão se refere aos agentes que tomaram as iniciativas de gestão: governo, sociedade civil, empresa, instituição multilateral, etc. A essas dimensões, acrescenta a dimensão filosófica, que diz respeito à visão de mundo e da relação entre o ser humano e a 
natureza que estão na base do gerenciamento ambiental adotado, questões que encontram variados posicionamentos, destacando-se duas grandes vertentes situadas em pólos extremos (as posições antropocêntricas extremadas e as posições ecocêntricas extremadas), com situações intermediárias em diferentes gradações, dentre as quais se encontram as abordagens sócio-ambientais, que embora reconheçam o valor intrínseco da natureza, admitem sua utilização para atender às necessidades humanas presentes e futuras, buscando sistemas de produção e consumo sustentáveis, ou seja, que atendam as necessidades humanas respeitando as limitações do meio ambiente, conforme já foi discutido no item que trata das diferentes abordagens conceituais de desenvolvimento sustentável.

Uma abordagem de gestão ambiental mencionada por SACHS (2000) diz respeito à conservação da biodiversidade pelo denominado "ecodesenvolvimento", definido por uma estratégia de conservação de áreas protegidas, diante de pressões insustentáveis decorrentes das necessidades e atividades dos povos que vivem nelas ou no seu entorno. Essa estratégia requer "o planejamento local e participativo, no nível micro, das autoridades locais, comunidades e associações de cidadãos envolvidas na proteção da área", visando a melhoria do nível de vida dos povos, pela identificação, criação e desenvolvimento de alternativas sustentáveis de uso dos recursos naturais e geração de renda, de maneira negociada e participativa (p. 73). No entanto, embora a criação de áreas protegidas faça parte da gestão ambiental territorial adequada, adverte o autor que a multiplicação de reservas não atingirá sua finalidade caso não sejam propiciados os meios necessários para a sua proteção efetiva.

De caráter multidisciplinar, a gestão ambiental envolve um conjunto de princípios, diretrizes e estratégias de ações e procedimentos estabelecidos pelos agentes socioeconômicos públicos e privados, tendo como objetivo administrar e coordenar a complexidade de fenômenos ecológicos que interagem com os processos humanos social, econômico e cultural, visando manter o fluxo dinâmico evolutivo dos sistemas naturais, assim como utilizar os efeitos benéficos dessa evolução para o desenvolvimento da cultura humana em bases sustentáveis (PHILIPPI JR e BRUNA, 2004). 
Da visão dos diversos autores citados, pode-se extrair que uma gestão ambiental pública eficiente e eficaz não pode prescindir da existência de uma política ambiental que traga no seu contexto a visão holística e o tratamento multidisciplinar das questões ambientais, com ampla participação e envolvimento de toda a sociedade na sua elaboração e execução, desde a fase de planejamento até a efetivação de ações concretas. A gestão deve, ainda, ser flexível, apresentando possibilidade de revisão e readequação periódicas face ao dinamismo dos sistemas natural e social, o quê somente será possível caso haja monitoramento e avaliação contínuos, por meio de indicadores adequados.

O modelo de gestão ambiental adotado pelo Brasil, entretanto, importado dos Estados Unidos e de outros países de alta renda, baseia-se principalmente na regulamentação ambiental de comando e controle, apresentando diversos problemas, alguns dos quais foram apontados no documento denominado de "Agenda Ambiental Marrom”, que trata da gestão dos problemas da poluição no nosso país, elaborado pelo Banco Mundial, em 1998. Esse documento menciona, como problemas comuns do atual sistema de gestão: "a) falta de prioridade para os problemas e intervenções; b) recursos e instrumentos ultrapassados de comando e controle; c) falta de integração das considerações ambientais às políticas de planejamento setorial; d) implementação e fiscalização ineficazes; e e) dependência excessiva de financiamento governamental" (BANCO MUNDIAL, 1998, v. 1, p. 18).

O documento aponta, também, dentre as principais causas desses problemas, a falta de informações adequadas e sistematizadas que possam orientar o estabelecimento de prioridades, bem como a capacidade limitada de análise, fatores que acabam não trazendo os resultados desejados. A cooperação limitada entre os interessados - setor privado, comunidades afetadas, ONGs, comunidade científica e governo - aliada à falta de integração entre municipalidades, estados e o governo federal, bem como entre os diversos setores de cada um destes, com a incorporação de considerações ambientais na seleção entre alternativas de investimento e de política, também são problemas comuns. A pouca capacidade de implementação de uma gestão adequada é consequiência, ainda, da existência de instituições ambientais fracas - quase sempre vistas como obstáculos custosos para as políticas de outros setores - as quais recebem poucos incentivos, recursos insuficientes e não têm o 
apoio político necessário para a fiscalização efetiva, fatos que acabam levando esses órgãos a deixarem de cumprir funções básicas, tais como a geração de informações ambientais críticas e a participação efetiva nos processos de planejamento e formulação de decisões. A geração de informações sólidas sobre a qualidade do meio ambiente, as fontes de emissões, os impactos da poluição - inclusive sobre a saúde pública - os custos de controle alternativos, dentre outros aspectos, aliás, são apontados pelo documento como a base para a formulação racional de política ambiental, bem como para uma gestão eficiente e eficaz, com a obtenção de resultados concretos.

A Agenda Ambiental Marrom propõe, como instrumentos modernos de gestão da poluição, além da geração de informações adequadas - que deve ser prioridade dos órgãos ambientais - o estabelecimento participativo de metas dinâmicas de qualidade ambiental por meio do desenvolvimento de planos de ação ambiental nos níveis nacional, metropolitano e municipal; a modernização do processo de licenciamento; e a introdução de instrumentos e conceitos econômicos no processo de licenciamento e nos sistemas de bacias hidrográficas, com a integração da gestão ambiental no contexto da gestão de recursos hídricos (BANCO MUNDIAL, 1998).

O conceito de gestão ambiental pública como a ação do Poder Público, com ampla participação da sociedade, para a implementação das políticas públicas ambientais - aqui incluídas não apenas aquelas voltadas para a proteção do meio ambiente natural, como também do construído ou artificial e do cultural - tendo como finalidade última a promoção da qualidade de vida, será utilizado como referencial teórico deste trabalho, por melhor se harmonizar com os objetivos do desenvolvimento sustentável.

\subsubsection{Gestão Ambiental no Setor Industrial}

A gestão ambiental no setor industrial é parte fundamental no processo de implementação das políticas públicas ambientais rumo ao almejado desenvolvimento sustentável. O gerenciamento ambiental empresarial, segundo SÁNCHEZ (1994), “é o conjunto de operações técnicas e atividades gerenciais que visa assegurar que um 
empreendimento opere dentro dos padrões legais ambientais exigidos, minimize seus impactos ambientais e atenda a outros objetivos empresariais, como manter um bom relacionamento com a comunidade" (p. 67).

Não há qualquer dúvida que a indústria e seus produtos exercem forte impacto sobre os recursos naturais ao longo de todo o seu ciclo - exploração e extração de matérias-primas, sua transformação em produtos, consumo de energia, geração de resíduos - tanto na produção, quanto após o uso e eliminação dos produtos pelos consumidores. Esse impacto pode ser positivo, melhorando a qualidade de um recurso ou ampliando seus usos, ou negativo, pelo esgotamento ou deterioração dos recursos, bem como pela poluição causada pelo processo produtivo e pelo produto.

Contudo, foram os impactos negativos que ganharam maior relevância, especialmente a partir dos anos 60, em razão da grande expansão industrial que se seguiu à II Guerra Mundial e que não levou em conta o meio ambiente, aumentando a poluição em níveis alarmantes, simbolizada pelo aumento da incidência de graves acidentes provocados por produtos químicos tóxicos, como, por exemplo, o envenenamento químico por mercúrio de Minamata, o smog de Los Angeles ou a poluição progressiva de rios como o Mosa, o Elba e o Reno, que fizeram aumentar as preocupações do público, iniciando-se um amplo debate sobre a conservação do meio ambiente e o crescimento econômico.

A partir de então, diversas medidas vêm sendo adotadas pelos governos e pelas indústrias visando à proteção do meio ambiente e à conservação dos recursos naturais, que vão desde instrumentos legais a instrumentos econômicos, passando pelo desenvolvimento de novos processos, produtos e tecnologias mais limpos e mais eficientes, tornando-se o controle da poluição um próspero ramo da indústria em vários países industrializados (CMMAD, 1991).

Segundo HUNT e AUSTER (1990), as empresas necessitam de programas de gerenciamento ambiental para responder da melhor maneira possível às exigências legais das autoridades governamentais, nos níveis federal, estadual e local, assim como para responder aos anseios do público, uma vez que, atualmente, tanto a mídia quanto os consumidores em geral focam maior atenção aos problemas ambientais. Dessa forma, ignorar esses aspectos pode acarretar graves consequiências ao 
desempenho das empresas, gerando perdas econômicas e danos à imagem destas por anos. Os autores identificam cinco estágios em que podem se encontrar as empresas quanto aos seus programas de gerenciamento ambiental. No primeiro estágio, encontram-se as empresas para as quais o gerenciamento ambiental é considerado desnecessário. No segundo estágio, estão aquelas em que a preocupação com os problemas somente surge quando estes ocorrem, caracterizando-se por uma postura reativa. As empresas do terceiro estágio demonstram um comprometimento ao menos teórico com o gerenciamento ambiental que, porém, acaba resultando em poucas ações. Para as empresas do quarto estágio, a gestão ambiental é uma importante função dos negócios e buscam atuar para minimizar os impactos ambientais negativos. No quinto e último estágio encontram-se as empresas para as quais o gerenciamento ambiental é um item prioritário, havendo um envolvimento ativo e diário de todos os seus setores, caracterizando-se por uma postura pró-ativa no trato dos problemas ambientais.

A performance ambiental de uma organização é determinada pelo grau de maturidade de seu sistema de gestão ambiental e da conscientização ambiental que ela apresenta, tanto no nível organizacional, quanto individual. A conscientização ambiental existe quando a variável ambiental é percebida de forma integrada na organização, determinando uma resposta de alta sistematização da gestão ambiental, voltada para o modelo preventivo, com boa assimilação das mudanças na cultura da empresa (PETILLO, 1997). Possíveis indicadores de performance ambiental do setor industrial, conforme SÁNCHEZ (1998), incluem intensidade do consumo de energia e água por unidade de produção; intensidade de consumo de matéria-prima por unidade de produção; emissão de poluentes; geração de resíduos e reutilização; porcentagem de tempo que as plantas estão obedecendo aos padrões de emissão; e número de acidentes ambientais por ano.

O gerenciamento ambiental é, ainda, um dos programas que melhor pode criar vantagem competitiva às corporações. Para tanto, afirma WELFORD (1995), as empresas precisam abandonar ideologias baseadas apenas no desempenho financeiro e considerar um relacionamento honesto e confiável da corporação com a sociedade, criando uma boa reputação e imagem públicas de longo prazo. Para o autor, o gerenciamento ambiental dentro de uma estrutura ética de negócios não permite, 
ainda, separar considerações ambientais de questões como o tratamento das mulheres e dos grupos minoritários, o tratamento dos animais e a proteção das populações indígenas.

No caminho rumo ao desenvolvimento sustentável, novos métodos de gestão ambiental empresarial também são fundamentais. O relatório "Nosso Futuro Comum" já alertava que a resposta da indústria à poluição e à deterioração dos recursos naturais não deveria se limitar ao atendimento das regulamentações, mas "comportar um amplo senso de responsabilidade social e garantir a conscientização das questões ambientais em todos os níveis" (CMMAD, 1991, p. 248).

A Agenda 21 global, que constitui um grande guia para se alcançar o desenvolvimento sustentável, documento aprovado na Conferência das Nações Unidas sobre Meio Ambiente e Desenvolvimento, realizada no Rio de Janeiro, em 1992, conforme já mencionado, dedicou um capítulo ao comércio e à indústria (Capítulo 30), no qual conclamou as empresas e suas entidades a reconhecerem como prioridade o manejo adequado do meio ambiente, fator determinante do desenvolvimento sustentável. Para tanto, a Agenda 21 estabeleceu duas áreas programas: a promoção de uma produção mais limpa e a promoção da responsabilidade empresarial (UNITED NATIONS, 1992).

A expressão "produção mais limpa" se refere a uma abordagem de proteção ambiental mais ampla, pois considera todas as fases do processo de fabricação e o ciclo de vida do produto, incluindo o seu uso nos domicílios e locais de trabalho, exigindo ações contínuas e integradas para conservar energia e matéria-prima, substituir recursos não renováveis por renováveis, eliminar substâncias tóxicas e reduzir os desperdícios e a poluição resultante dos produtos e dos processos produtivos. Define-se como uma estratégia tecnológica de caráter permanente que se contrapõe às soluções que objetivam controlar a poluição apenas atuando no final do processo produtivo. As tecnologias de produção mais limpa contemplam tanto mudanças nos produtos quanto nos seus processos de produção, ampliando a sustentabilidade dos sistemas naturais, pela redução da quantidade de insumos exigidos para um mesmo nível de produção, pela redução ou eliminação de todo tipo de rejeitos antes que eles sejam gerados, bem como redução da poluição resultante do processo de produção, distribuição e consumo, passando, ainda, pela reutilização 
e reciclagem. De acordo com essa abordagem, os fabricantes são co-responsáveis por seus produtos mesmo após a venda e consumo juntamente com seus usuários ou consumidores (BARBIERI, 2006).

Segundo CORREIA (2005), as disposições do art. $3^{\circ}$, inciso IV, e art. $14, \S$ $1^{\circ}$, da Lei 6.938/81 - que, respectivamente, conceitua poluidor como a pessoa física ou jurídica, de direito público ou privado, responsável, direta ou indiretamente, por atividade causadora de degradação ambiental, e estabelece a responsabilidade civil objetiva por danos ambientais, sob a modalidade do risco integral da atividade, este último recepcionado pela Constituição Federal de 1988 (art. 225, § 3º) - já seriam suficientes para afirmar o reconhecimento da co-responsabilidade dos fabricantes por seus produtos após a venda e consumo no direito brasileiro. Essa responsabilidade encontra fundamento nos princípios do poluidor-pagador, que determina a internalização dos custos de proteção do meio ambiente, e da prevenção que, conforme a autora, impõe aos fabricantes o dever de fornecer produtos que gerem o mínimo possível de resíduos após o consumo, bem como que aqueles inevitavelmente gerados possam ser aproveitados. A autora afirma, ainda, que o caráter poluente de resíduos gerados pós-consumo, desde que represente riscos ambientais não legitimamente esperados pela coletividade, poderia ser considerado um defeito do produto ou serviço, nos termos dos arts. 12 e 14, do Código de Defesa do Consumidor, assim como a falta de informações ou informações distorcidas sobre esse caráter poluente. Nesse caso, a coletividade estaria equiparada a consumidor, em razão da lesão ao meio ambiente decorrer de uma relação de consumo. A Lei federal $\mathrm{n}^{\circ} 7.802 / 89$, que trata dos agrotóxicos, com as modificações introduzidas pela Lei $\mathrm{n}^{\circ}$ 9.974/00 (art. $6^{\circ}, \S 5^{\circ}$, e art. 14, alínea "e”), é um exemplo de legislação brasileira nesse sentido, assim como as Resoluções CONAMA nº 257/99 e 258/99, que dispõem, respectivamente, sobre a destinação final de pilhas e baterias e destinação final dos pneumáticos inservíveis.

O programa de responsabilidade empresarial proposto pela Agenda 21, por sua vez, objetiva estimular o conceito de vigilância no manejo e utilização dos recursos naturais e aumentar o número de empresários cujas empresas apóiem e implementem políticas de desenvolvimento sustentável, recomendando, entre outras medidas, o aumento dos investimentos em P \& D (Pesquisa e Desenvolvimento) de 
tecnologias ambientalmente saudáveis e de sistemas de manejo ambiental, em conjunto com instituições de ensino e pesquisa, bem como o manejo responsável e ético de produtos e processos dos pontos de vista da saúde, da segurança e do meio ambiente (UNITED NATIONS, 1992).

BARBIERI (1997) afirma que as empresas não devem se preocupar com o meio ambiente apenas para atender os requisitos legais, "mas também para alcançar objetivos econômicos compatíveis com padrões sustentáveis de desenvolvimento" (p. 68), adiantando-se às exigências legais, estabelecendo uma relação de soma positiva entre suas atividades e o meio ambiente. Segundo o autor, da análise da trajetória das empresas que passaram a se preocupar com o meio ambiente, pode-se concluir que esse caminho é determinado, inicialmente, por exigências legais ou por pressões da comunidade, levando, quase sempre, à adoção de medidas corretivas. O passo seguinte direciona-se a uma produção mais eficiente, poupadora de materiais e energia e, consequentemente, geradora de menos poluentes, baseada no conceito de tecnologia ou produção mais limpa. Em uma terceira etapa, o meio ambiente passa a ser tratado dentro de uma perspectiva estratégica, sendo inserido entre as prioridades máximas da empresa e envolvendo todas as suas áreas funcionais, abrangendo a redução sistemática de custos, via produção mais limpa, e o aproveitamento das oportunidades proporcionadas pelo crescimento da consciência ambiental geral.

MOURA (1998) aponta diversas razões para que as empresas busquem a melhoria do desempenho ambiental de produtos e processos de produção: maior satisfação dos clientes, melhoria da imagem da empresa, conquista de novos mercados, redução de custos, melhoria do desempenho produtivo da empresa, redução dos riscos, melhoria da administração da empresa, maior permanência do produto no mercado, maior facilidade na obtenção de financiamentos, maior facilidade na obtenção de certificação e maior credibilidade pela transparência.

O crescimento da consciência ambiental fez surgir diversos sistemas de gestão ambiental que podem ser adotados pelas empresas, embora essas possam criar seus próprios sistemas. Alguns desses sistemas são mundialmente conhecidos e aplicados no setor empresarial, os quais serão brevemente comentados no item seguinte. 


\subsubsection{Sistemas de Gestão Ambiental}

O Programa de Atuação Responsável pode ser tido como um dos primeiros sistemas padronizados de gerenciamento ambiental utilizado pelas empresas. Criado no Canadá, em 1984, para as indústrias químicas, consiste em um código voluntário de desempenho onde a performance é medida em termos de melhorias contínuas. Caracteriza-se pelo comprometimento formal à integração da visão de melhoria contínua na política geral da empresa, quanto aos aspectos de seu desempenho ambiental, segurança das instalações, processos e produtos e preservação da saúde ocupacional dos trabalhadores. A adesão aos seus princípios e objetivos é condição para que a indústria se torne membro da Associação de Indústrias Químicas. Todos os trabalhadores da empresa devem estar conscientes dos princípios do programa, que tem como linhas principais: conformidade com a legislação; adoção das melhores práticas industriais; avaliação dos atuais e potenciais impactos de suas atividades e produtos sobre a saúde, segurança e meio ambiente; trabalhar próximo das autoridades e da comunidade para alcançar os níveis de desempenho exigidos; estar aberto a atividades diversas e fornecer informações relevantes para as partes interessadas (WELFORD, 1995).

Conforme Welford, o princípio-chave do programa consiste na autoavaliação, sendo as empresas encorajadas a submeterem seis indicadores de desempenho à Associação: 1) gastos com proteção ambiental; 2) segurança e saúde (perda de tempo, acidentes de trabalhadores); 3) resíduos e emissões: a) descargas de substâncias da "lista vermelha"; b) disposição de resíduos; c) um índice ambiental de cinco lançamentos-chave da planta; 4) distribuição de todos os incidentes; 5) consumo total de energia; e 6) todas as reclamações.

No Brasil, o Programa de Atuação Responsável foi adotado oficialmente pela Associação Brasileira da Indústria Química (ABIQUIM), em 1992, e está baseado em seis componentes: princípios diretivos, códigos de práticas gerenciais, comissões de lideranças empresariais, conselhos comunitários consultivos, avaliação de progresso e difusão da cadeia produtiva. A adesão era voluntária até 1998, quando passou a ser obrigatória para todos os associados da ABIQUIM, como ocorre em outros países que o adotaram. 
Os princípios diretivos fundamentam-se na prevenção da poluição, melhoria contínua e diálogo permanente com órgãos governamentais, funcionários, fornecedores, consumidores, comunidade e público em geral. Os códigos gerenciais, em número de seis, consistem nos seguintes: a) segurança de processos; b) saúde e segurança do trabalhador; c) proteção ambiental; d) transporte e distribuição; e) diálogo com a comunidade e preparação e atendimento a emergências; e f) gerenciamento do produto. As Comissões de Lideranças Empresariais têm por objetivo debater e trocar experiências entre profissionais e dirigentes de empresas associadas, enquanto os Conselhos Comunitários Consultivos visam estreitar o diálogo das indústrias com as comunidades vizinhas e com o público em geral, na busca de respostas e soluções para os problemas levantados. A avaliação de progresso procura acompanhar a implantação do programa visando seu aperfeiçoamento. $\mathrm{O}$ último componente consiste na difusão dos valores e práticas do programa para toda a cadeia produtiva, por meio de parcerias com transportadores e distribuidores de produtos químicos e com tratadores de resíduos químicos (ABIQUIM, 2006).

Conforme BARBIERI (2006), o Atuação Responsável é um programa de auto-regulamentação, no qual as empresas vão além do cumprimento das exigências legais, por exemplo, compartilhando experiências e ouvindo as preocupações da comunidade.

Outro sistema de gerenciamento ambiental bastante difundido é o Total Quality Environmental Management (TQEM) [Administração da Qualidade Ambiental Total], o qual consiste em uma ampliação dos conceitos de Administração da Qualidade Total (TQM) [Total Quality Management], porém voltado para as questões ambientais, cuja criação é atribuída ao Global Environmental Management Initiative (GEMI) [Iniciativa de Gerenciamento Ambiental Global]. O TQM é uma abordagem de gerenciamento baseada no envolvimento de todos os membros de uma organização e seus fornecedores, num esforço contínuo para produzir e comercializar bens e serviços que atendam às expectativas de seus clientes ou usuários.

O TQEM, conforme BARBIERI (2006), apresenta os mesmos elementos básicos do TQM, quais sejam: "foco no cliente, qualidade como uma dimensão estratégica, processos como unidade de análise, participação de todos, trabalho em 
equipe, parcerias com os clientes e fornecedores e melhoria contínua" (p. 118). O TQEM consiste em um processo de planejamento ambiental de longo prazo, por meio da melhoria contínua de todas as atividades da empresa, mediante o envolvimento de todos os seus integrantes e colaboradores, tendo como meta a poluição zero e como objetivo final a satisfação de todas as partes interessadas.

O sistema da gestão ambiental ISO 14001, bastante conhecido e utilizado pelas empresas brasileiras, foi criado pela International Organization for Standardization (ISO) [Organização Internacional de Padronização], organização internacional não governamental, sem fins lucrativos, composta por mais de cem países membros, sediada em Genebra, Suíça, tendo como finalidade desenvolver normas de fabricação, comércio e comunicações, por meio de acordos técnicos internacionais, respaldados na ciência, tecnologia e experiência. Por se tratar de uma organização de caráter privado, todas as suas normas são de adesão voluntária (D’LSEP, 2004).

O modelo de sistema de gestão ambiental da ISO 14001 é baseado no ciclo PDCA, o qual é composto por quatro grandes passos: Plan [planejar], Do [realizar]; Check [verificar]; e Act [atuar para corrigir], recomeçando o ciclo. A fase de planejamento envolve o diagnóstico ambiental da empresa e a elaboração do plano de implementação do Sistema de Gestão Ambiental, com a identificação dos aspectos e impactos ambientais, dos requisitos legais e corporativos, estabelecimento de objetivos e metas e de um plano de ação e programa de gestão ambiental. A segunda fase consiste na implementação e operacionalização do sistema, com a alocação dos recursos necessários, definição de estrutura e responsabilidades, conscientização e treinamento de todos os membros da organização, comunicação interna e externa, documentação, controle operacional, programas de gestão e preparação e resposta a emergências. A avaliação periódica, por meio de monitoramento e medições, permite verificar desconformidades e adotar ações corretivas e preventivas, além de avaliar o atendimento a requisitos legais, dentre outros. O controle de registros e a realização de auditorias internas do sistema de gestão também estão incluídos nesta fase. O sistema de gestão ambiental deve ser periodicamente analisado pela alta administração da empresa, a fim de se verificar 
sua adequação, pertinência e eficácia, permitindo a melhoria contínua do desempenho ambiental da empresa.

O ponto de partida para a adoção do sistema de gestão ambiental ISO 14001 é a formulação da política ambiental da empresa e o comprometimento da alta administração com a política estabelecida que, conforme a norma NBR ISO 14001:2004, dentro do escopo do sistema de gestão ambiental definido, deve ser apropriada aos impactos ambientais das atividades, produtos e serviços da empresa e incluir obrigatoriamente comprometimento com a melhoria contínua, prevenção da poluição e o atendimento aos requisitos legais aplicáveis. Essa política deve, ainda, fornecer a estrutura para o estabelecimento e análise dos objetivos e metas ambientais, ser documentada, implementada, mantida, comunicada a todos os membros da organização e estar disponível para o público (MOREIRA, 2006).

A ISO 14001 não versa sobre normas técnicas ou relativas a produto, mas sobre um conjunto abrangente de normas e instrumentos para os diferentes aspectos de uma gestão ambiental, visando viabilizar a certificação da empresa, que será feita por entidades credenciadas. Obtida a certificação, são requisitos absolutos para sua manutenção o atendimento à legislação e regulamentos aplicáveis e a promoção da melhoria contínua, contribuindo este último requisito para que o sistema de gestão ambiental se mantenha vivo, não se tornando obsoleto. A normalização cria uma linguagem comum e, no caso das normas de gestão ambiental, a exemplo da ISO 14001, "gera um instrumento a mais da política nacional e internacional de proteção do meio ambiente, além de auxiliar na concretização da função socioambientaleconômica da pessoa jurídica ao adotá-la e do exercício da cidadania ambiental da pessoa física ao privilegiar tais iniciativas" (D'LSEP, 2004, p. 152).

AGUIAR (2004), em trabalho que analisa o desempenho de sistemas de gestão ambiental na indústria química, aponta quatro oportunidades de melhoria da norma ISO 14001: melhor comunicação com partes interessadas; controle efetivo de produtos e serviços adquiridos, com maior envolvimento de empresas de médio e pequeno porte; uso de indicadores para monitoramento do desempenho e comunicação destes; e gerenciamento da responsabilidade do produto.

A Associação Brasileira de Normas Técnicas (ABNT) é a entidade que representa oficialmente o Brasil na ISO e vice-versa. Trata-se de entidade civil, sem 
fins lucrativos e de utilidade pública, que integra o Sistema Nacional de Metrologia, Normalização e Qualidade Industrial, do qual também fazem parte o Instituto Nacional de Metrologia, Normalização e Qualidade Industrial (INMETRO) e o Conselho Nacional de Metrologia, Normalização e Qualidade Industrial (CONMETRO), nos termos da Lei Federal 5.966/73. A ABNT foi reconhecida como único Fórum Nacional de Normalização pela Resolução n 07 do CONMETRO, de 24/08/1992.

Sem ingressar na avaliação da eficiência de cada um dos sistemas, que foge ao âmbito deste trabalho, importante é que, qualquer que seja o sistema de gestão ambiental adotado, o gerenciamento do setor industrial seja feito com a inserção da dimensão ambiental em todas as fases do processo produtivo, sem esquecer, ainda, da dimensão social, visto que no desenvolvimento sustentável esses aspectos devem estar em harmonia com os objetivos econômicos.

Questão fundamental para a avaliação do progresso na direção do desenvolvimento sustentável, reiteradamente apontada pelos diversos autores citados neste trabalho, diz respeito à existência de informação adequada para orientar esse processo, na forma de indicadores, assunto que será tratado no tópico seguinte.

\subsection{INDICADORES DE DESENVOLVIMENTO SUSTENTÁVEL}

2.3.1. A Informação no Processo de Promoção do Desenvolvimento Sustentável

A Agenda 21 Global, documento de planejamento estratégico de promoção do desenvolvimento sustentável aprovado na Conferência das Nações Unidas sobre Meio Ambiente e Desenvolvimento, realizada no Rio de Janeiro, em 1992, destacou o papel da informação nesse processo, dedicando, inclusive, um capítulo específico ao tema (capítulo 40), partindo do princípio de que todos são usuários e provedores de informação, aqui incluídos dados, experiências e conhecimento. 
No mesmo sentido dispõe o princípio 10 da Declaração do Rio sobre Meio Ambiente e Desenvolvimento (1992), o qual estabeleceu a participação social no trato das questões ambientais como necessária à implementação do desenvolvimento sustentável, ressaltando a importância da informação adequada para assegurar a efetividade desse processo.

Segundo a Agenda, a informação adequada deve ser útil e compreensível, tanto para o setor governamental como para o público em geral, a partir da identificação de suas necessidades, proporcionando bases sólidas para o processo de decisão em todos os níveis: internacional, nacional, regional e local. A disseminação dessas informações também constitui aspecto fundamental para o alcance do desenvolvimento sustentável. Definiu-se, então, que a informação necessária para a implementação do desenvolvimento sustentável deveria vir estabelecida na forma de indicadores, os quais devem ser relevantes, confiáveis, e de fácil acesso (UNITED NATIONS, 1992).

Diversas são as definições encontradas para o termo indicador, o qual é derivado do latim "indicare", que significa tornar patente, demonstrar, revelar, denotar (FERREIRA, 1999). RIBEIRO (2006) define indicador como "algo que nos conta o que está acontecendo ou que está para acontecer” (p. 97).

A necessidade de indicadores que nunca precisamos antes surgiu da evidência da insustentabilidade de muitas das atividades humanas. Para MEADOWS (1998, p. 1-2) "indicadores são uma parte necessária do fluxo de informações que nós usamos para entender o mundo, tomar decisões e planejar nossas ações. Indicadores derivam de valores (medimos aquilo com que nos preocupamos) e criam valores (nos preocupamos com aquilo que medimos)". Indicadores de desenvolvimento, para a autora, devem ser mais que indicadores de crescimento. Eles devem ser sobre eficiência, suficiência, equidade e qualidade de vida.

Segundo PHILIPPI JR et al. (2005) indicadores de desenvolvimento sustentável são parâmetros utilizados para o monitoramento da sustentabilidade de um modelo adotado de desenvolvimento.

A importância de uma visão clara de desenvolvimento sustentável, aliás, é a base de toda avaliação que possa ser feita do progresso obtido naquela direção. Tal aspecto é destacado nos princípios de Bellagio (princípio 1), estabelecidos em 1996 
por um grupo internacional de pesquisadores e especialistas em sistemas de avaliação, que se reuniu com essa finalidade na Fundação de Estudos Rockefeller e Centro de Conferências, em Bellagio, na Itália, que também estabelece que essa visão deve vir definida em objetivos práticos (HARDI e ZDAN, 1997).

Também para BOSSEL (1999) o conceito de sustentabilidade adotado, ou seja, a interpretação que damos a esse conceito, irá direcionar nosso foco para certos indicadores e, simultaneamente, fazer com que negligenciemos outros tantos, definindo e limitando os problemas que podemos perceber e, conseqüentemente, o tipo de desenvolvimento sustentável que podemos alcançar.

Qualquer proposta séria de mensuração do fenômeno do desenvolvimento sustentável, conforme BRAGA et. al (2004), deve iniciar pela declaração do conceito de sustentabilidade adotado, o qual permanece em constante processo de construção e reconstrução, não havendo uma referência consolidada de padrões de relação entre conservação ambiental e crescimento econômico.

O desenvolvimento sustentável, afirma Bossel, "envolve as dimensões ambiental, material, ecológica, social, econômica, legal, cultural, política e psicológica" (p. 2) e necessitamos de indicadores capazes de fornecer informações essenciais e confiáveis sobre a viabilidade de todos esses aspectos do sistema, assim como do sistema como um todo, de forma a orientar as políticas e decisões em todos os níveis da sociedade. Por esse motivo, precisam ser claramente definidos, reproduzidos, compreensíveis, práticos e não podem conter ambigüidades, de molde que permitam verificar a viabilidade e sustentabilidade do desenvolvimento que vem sendo praticado e comparar com caminhos alternativos, de forma simples e rápida, por todos os grupos interessados, independentemente do nível educacional (BOSSEL, 1999).

Indicadores de desenvolvimento sustentável podem ser definidos, portanto, como as informações necessárias para monitorar a sustentabilidade do desenvolvimento que vem sendo praticado, de modo a permitir as mudanças de caminho exigidas para alcançar esse objetivo.

Nos próximos itens abordaremos a importância dos indicadores para a gestão ambiental no processo de implementação das políticas públicas ambientais (2.3.2.), algumas das limitações existentes no processo de construção e utilização de 
indicadores (2.3.3.) e, por último, serão mencionadas, brevemente, algumas das principais experiências internacionais (2.3.4.) e nacionais (2.3.5.) de construção de indicadores de desenvolvimento sustentável.

\subsubsection{A Importância dos Indicadores na Gestão Ambiental}

O caminho em direção ao desenvolvimento sustentável, que resulte em um desenvolvimento economicamente eficiente, com equidade e responsabilidade social e ambientalmente equilibrado, exige a integração das questões sócio-econômicas e ambientais no processo de tomada de decisões.

Conforme PHILIPPI JR et. al (2005, p. 762) “a construção de políticas e processos de planejamento e gestão que direcionem o desenvolvimento em patamares sustentáveis" deve ser priorizada. Entretanto, um dos principais aspectos que dificulta o processo de gestão na direção do desenvolvimento sustentável é a falta de informação adequada, especialmente a dados integrados da situação econômica, social e ambiental.

A Agenda 21 global, conforme mencionado no item anterior, enfatizou, em seus capítulos 8 e 40, a necessidade de desenvolver indicadores capazes de medir o progresso da sociedade na direção do desenvolvimento sustentável, diante da constatação de que as informações existentes não eram adequadamente gerenciadas, muitas vezes por falta de recursos financeiros, falta de capacitação, falta de consciência do valor das informações ou, ainda, pela não disponibilidade destas. Constatou-se, também, que mesmo onde existiam informações, estas não eram facilmente acessíveis, seja por falta de tecnologia adequada, seja pelos custos associados. Ademais, havia necessidade de coleta de novos e diferentes tipos de dados, nos níveis local, regional, nacional e internacional, que indicassem o estado e as tendências dos ecossistemas e recursos naturais do planeta, bem como incluíssem variáveis sócio-econômicas (UNITED NATIONS, 1992).

BRAGA et. al (2004) argumentam que no processo de tomada de decisões versando sobre a relação entre meio ambiente e desenvolvimento prevalece a incerteza e a carência de informações sistematizadas, sendo crucial e urgente a criação de indicadores confiáveis que possam embasar estudos e tomadas de decisão 
política. Segundo os autores, "mensurar a sustentabilidade requer a integração de um número considerável de informações advindas de uma pluralidade de disciplinas e áreas de conhecimento" (p. 15), somada ao desafio de comunicar tais informações de forma coerente ao público.

Os indicadores de sustentabilidade, assim como seu processo de desenvolvimento, além de contribuírem para a melhoria da compreensão do que seja exatamente o desenvolvimento sustentável, fornecem subsídios e melhoram o processo decisório em todos os níveis, melhorando a política ambiental. BELLEN (2005) afirma que "o processo de gestão necessita de mensuração. A gestão de atividades e o processo decisório necessitam de novas maneiras de medir o progresso, e os indicadores são uma importante ferramenta nesse processo” (p. 54).

Sob o enfoque sistêmico, conforme TAYRA e RIBEIRO (2006), os sistemas de indicadores têm como objetivo construir um conjunto de indicadores capazes de revelar as "principais tendências, tensões e causas subjacentes aos problemas da sustentatibilidade" (p. 87).

Para PHILIPPI JR et. al (2005) "a função de um indicador é fornecer uma 'pista' de um problema de grande importância ou tornar perceptível uma tendência que não está imediatamente visível, favorecendo maior dinamismo no processo de gestão" (p. 764).

Indicadores fornecem informações significativas em uma quantidade gerenciável que irá informar o processo decisório e direcionar as ações. Assim, precisam fornecer informações relevantes sobre o estado atual e viabilidade do sistema, bem como informações suficientes para permitir a intervenção adequada, inclusive no tempo adequado, e o sucesso dessa intervenção para o alcance do objetivo da sustentabilidade. Por esse motivo, também é importante que o conjunto de indicadores seja flexível e possa ser periodicamente reavaliado e revisado em resposta a eventuais mudanças ambientais, sociais ou tecnológicas (MEADOWS, 1998).

Indicadores, segundo Meadows, podem ser importantes ferramentas de mudança e aprendizado, ocupando o centro dos processos de decisão e orientando a adoção de políticas e ações. Mudanças de comportamento de um sistema podem ocorrer dependendo de sua presença ou ausência, correção ou incorreção, uso ou não 
uso. Assim, indicadores inadequados podem ocasionar reações que não levam ao estado desejado. Entretanto, a existência de bons indicadores de desenvolvimento sustentável, no momento adequado, claros, corretos e visíveis, tornam quase impossível não tomar decisões e adotar ações que melhorem esses indicadores.

As informações em forma de indicadores também são importantes para a melhoria do processo de comunicação, devendo ser acessível a todos os atores da sociedade, possibilitando a participação de todos os setores no processo de gestão. Além de exercerem papel fundamental no planejamento, tomada de decisões, monitoramento e avaliação da implantação das políticas e ações de desenvolvimento sustentável, têm grande importância para a mobilização e conscientização da comunidade (PHILIPP JR et. al, 2005).

\subsubsection{Limitações no Processo de Construção e Utilização de Indicadores}

A construção e o uso de indicadores, a despeito de sua importância, enfrenta problemas e limitações, alguns dos quais serão abordados neste item, sem a pretensão de esgotamento do tema.

BOSSEL (1999) argumenta que a maioria dos indicadores de sustentabilidade não reflete a viabilidade e operação do sistema total, havendo perda de informação vital, por falta de um sistema teórico conceitual adequado.

Conforme relata MEADOWS (1998), dentre outros aspectos que dificultam o processo de criação e utilização de indicadores, está a superagregação de diversas informações em um único índice, podendo levar a mensagens não-interpretáveis. Outro problema relatado pela autora é que ocorre mais a mensuração daquilo que é mensurável que daquilo que é realmente importante, questão que ganha relevância quando se verifica a necessidade de informação qualitativa.

Um problema recorrente, afirmam TAYRA e RIBEIRO (2006), refere-se à disponibilidade de dados que, muitas vezes, não existem, possuem qualidade duvidosa ou não existem na escala desejada. Os autores apontam, ainda, o problema da escolha de variáveis, uma vez que as metodologias adotadas podem esconder a necessidade de ampla discussão a respeito. 
Nesse aspecto, MEADOWS (1998) também menciona o problema da dependência de falsos modelos que podem levar a resultados ambíguos, assim como a própria falsificação deliberada de informações. Os indicadores, quando mal formulados ou baseados em modelos não confiáveis, afirma a autora, podem levar a sociedade a uma percepção falsamente positiva da realidade.

Também são apontadas como limitações para a avaliação da sustentabilidade a dificuldade de comparação de dados produzidos com base em diferentes fontes ou metodologias (BRAGA et. al, 2004), ou, ainda, conforme menciona BELLEN (2005), a agregação e a comparação de dados não compatíveis, como, no exemplo citado pelo autor, comparar perdas na biodiversidade com ganhos econômicos.

A dificuldade relativa aos custos de construção de sistemas de indicadores de qualidade e sua operação ao longo do tempo é outro desafio apontado por RIBEIRO (2006), além da ainda insuficiente valorização dada pelo poder público à produção desse tipo de informação de forma oportuna e transparente, em relação a outras prioridades da agenda política.

A precária disponibilidade de informação com qualidade somada às dificuldades no acesso a esta são obstáculos a serem transpostos para a realização da meta do desenvolvimento sustentável (UNITED NATIONS, 1992).

A existência de indicadores claros, conforme adverte MEADOWS (1998), não garante a obtenção de resultados, mas estimula a adoção de ações e solução de problemas, fato impossível sem indicadores apropriados. Contudo, não basta a existência desses indicadores, é preciso que sejam incorporados nas políticas de desenvolvimento e que a população seja informada claramente, honestamente, sobre as conseqüências de suas ações. É preciso que os indicadores sejam capazes de compelir as pessoas a mudarem seu comportamento na direção da sustentabilidade.

A despeito de todas as dificuldades, sendo os indicadores importantes instrumentos de planejamento, assim como de avaliação das ações resultantes das políticas públicas voltadas para a promoção do desenvolvimento sustentável, todo esforço na busca e aperfeiçoamento de um sistema adequado é necessário. Algumas das principais experiências internacionais e do Brasil nessa busca serão mencionadas nos próximos itens. 


\subsubsection{A Busca por Indicadores de Desenvolvimento Sustentável: Experiências}

\section{Internacionais}

A busca por indicadores de desenvolvimento sustentável apropriados vem sendo feita há vários anos e em diferentes níveis de organização da sociedade: pequenas comunidades, cidades, regiões, países, assim como no nível mundial. De acordo com BOSSEL (1999), nas pesquisas e trabalhos já desenvolvidos parece haver um consenso de que um indicador simples de desenvolvimento sustentável, tal como o PIB (Produto Interno Bruto), que há muito tempo vem sendo utilizado para medir o valor total em dinheiro do fluxo anual de bens e serviços produzidos em uma economia, não é suficiente, sendo necessário um número substancial de indicadores representativos capazes de capturar todos os aspectos importantes do desenvolvimento sustentável, tarefa que não é das mais simples.

Em resposta a essas falhas foram desenvolvidos indicadores agregados, tais como o Índice de Desenvolvimento Humano (IDH) e o Index of Sustainable Economic Welfare (ISEW) [Índice de Bem-Estar Econômico Sustentável], posteriormente transformado no Genuine Progress Indicator (GPI) [Indicador Genuíno de Progresso], os quais, porém, segundo o mesmo autor, apresentam sérias deficiências, uma vez que agregam na mesma unidade de medida aspectos que não podem ser mensurados da mesma forma.

Uma das críticas ao IDH, índice baseado em uma média aritmética dos desempenhos da renda per capita, da saúde e da educação, é que, embora seja um ponto de partida, não é uma medida compreensiva capaz de medir adequadamente o desenvolvimento sustentável, posto que não inclui, por exemplo, a capacidade das pessoas participarem das decisões da comunidade e de gozarem o respeito dos outros. Assim, ainda que ricas, saudáveis e instruídas, sem a capacidade de participar das decisões, o desenvolvimento é retardado. Índices compostos por várias dimensões que, por sua vez, resultam de diversas variáveis, "costumam ser contraproducentes, para não dizer enganosos ou traiçoeiros" (VEIGA, 2006, p. 36).

A Pegada Ecológica (Ecological Footprint), que mede o total de área de terra necessária para manter a demanda de alimentos, água, energia e disposição de resíduos por pessoa, por produto ou por cidade, por seu turno, é um excelente 
indicador agregado para medir os impactos ambientais das atividades econômicas. Contudo, sua limitação está em não incorporar a dimensão social do desenvolvimento sustentável (BOSSEL, 1999).

A Comissão de Desenvolvimento Sustentável (CDS) das Nações Unidas aprovou, em 1995, um programa de trabalho sobre indicadores de desenvolvimento sustentável que incluiu uma lista de 134 indicadores organizados no modelo pressãoestado-resposta, representando, respectivamente, as atividades humanas e os processos e padrões que têm impacto sobre o desenvolvimento sustentável, o estado atual deste e as opções políticas e ações necessárias para mudar esse estado. Esses indicadores foram concebidos para serem utilizados nos processos de tomada de decisões a nível nacional, não sendo, porém, aplicáveis em todas as situações, diante das diferentes prioridades e objetivos dos diversos países (UNITED NATIONS, 1996).

Na visão de BOSSEL (1999), as estruturas pressão-estado-resposta e pressãoestado-impacto-resposta, entretanto, negligenciam a natureza sistêmica e dinâmica dos processos e sua inserção em um sistema maior, motivo pelo qual múltiplas pressões e impactos não são considerados, assim como as relações não lineares entre os diferentes componentes de um sistema.

Posteriormente, a CDS abandonou o modelo pressão-estado-resposta, adotando um novo marco referencial, baseado em quatro dimensões - ambiental, social, econômica e institucional - divididas em temas e sub-temas, e efetuou uma revisão dos indicadores, reduzindo-os para 57 (UNITED NATIONS, 2001a). Segundo PHILLIPI JR et al. (2005), essa revisão "propôs ênfase para indicadores que dessem resposta para a tomada de decisões, para a elaboração de políticas ou como temas-chave para o desenvolvimento sustentável” (p. 784), considerando, para cada tema, o risco futuro, sua correlação com o atendimento dos objetivos da sustentabilidade e o atendimento às necessidades sociais básicas.

Importante trabalho foi o realizado em 1996 por um grupo internacional de pesquisadores e especialistas em sistemas de avaliação, que se reuniu na Fundação de Estudos Rockefeller e Centro de Conferências, em Bellagio, na Itália, conforme mencionado no item 2.3.1., visando melhorar o processo de avaliação do progresso na direção do desenvolvimento sustentável. Esse grupo estabeleceu alguns princípios 
que servem como um roteiro para essa avaliação, denominados "Princípios de Bellagio", os quais incluem o processo de escolha de indicadores, a forma e interpretação destes, bem como a comunicação dos resultados.

Os Princípios de Bellagio (traduzidos de HARDI e ZDAN, 1997), consistem nos seguintes:

Princípio 1-Visão direcionada e objetivos: toda avaliação deve ter como base uma visão clara de desenvolvimento sustentável e objetivos que definam essa visão.

Princípio 2-Perspectiva holística: incluir a revisão do sistema como um todo e de suas partes; considerar o bem estar dos subsistemas social, ecológico e econômico, tanto seu estado quanto a direção e taxa de mudança desses estados, de suas partes componentes e a interação entre estas; considerar as consequências positivas e negativas da atividade humana, de maneira a refletir os custos e benefícios para os sistemas humano e ecológico, em termos monetários e não monetários.

Princípio 3-Elementos essenciais: considerar a equidade e as disparidades dentro da atual população e entre as presentes e futuras gerações, lidando tanto com as preocupações quanto com o uso de recursos, o consumo exagerado e a pobreza, os direitos humanos e o acesso a serviços, se cabível; considerar as condições ecológicas das quais a vida depende; considerar o desenvolvimento econômico e outras atividades fora do mercado que contribuem para o bem-estar humano e social.

Princípio 4-Escopo adequado: adotar um horizonte de tempo longo o suficiente para englobar as escalas de tempo humana e dos ecossistemas, respondendo às necessidades de curto prazo dos tomadores de decisão, assim como àquelas das futuras gerações; definir o espaço do estudo amplo o suficiente para incluir, além dos impactos locais, os impactos distantes sobre as pessoas e ecossistemas; construir sobre as condições históricas e atuais para antecipar as condições futuras: onde queremos ir, onde podemos ir.

Princípio 5-Foco prático: adotar um conjunto explícito de categorias ou uma estrutura organizada que ligue as visões e objetivos aos indicadores e critérios de avaliação; um número limitado de questões para análise; um número limitado de indicadores ou combinações de indicadores para fornecer um sinal mais claro de 
progresso; comparar valores dos indicadores a metas, valores de referência, variáveis, limiares ou tendências de direção, se cabível.

Princípio 6-Abertura: fazer com que os métodos e dados que são utilizados sejam acessíveis a todos; deixar explícitos todos os julgamentos, suposições e incertezas dos dados e interpretações.

Princípio 7-Comunicação efetiva: ser concebida para direcionar para as necessidades da audiência e do conjunto de usuários; ser formulada por meio dos indicadores e outras ferramentas que estimulem e engajem os tomadores de decisões; objetivar simplicidade na estrutura e fazer uso de linguagem clara e abrangente.

Princípio 8-Ampla participação: obter ampla representação da população chave, profissionais, técnicos e grupos sociais, incluindo jovens, mulheres e população indígena, para assegurar o reconhecimento de valores diversos e em mudança; assegurar a participação dos tomadores de decisão para garantir uma firme ligação entre as políticas adotadas e as ações resultantes.

Princípio 9-Avaliação contínua: desenvolver capacidade de avaliação constante para determinar tendências; ser interativa, adaptável e sensível a mudanças e incertezas porque os sistemas são complexos e mudam freqüentemente; ajustar objetivos, estruturas e indicadores, assim que novos conhecimentos sejam adquiridos; promover o desenvolvimento do aprendizado coletivo e feedback para a tomada de decisões.

Princípio 10-Capacidade institucional: estabelecer claramente as responsabilidades e dar suporte contínuo ao processo de tomada de decisão; fornecer capacidade institucional para a coleta, manutenção e documentação de dados; dar suporte ao desenvolvimento da capacidade de avaliação local.

Na visão de MEADOWS (1998), a decisão para o desenvolvimento sustentável implica assumir responsabilidade para o desenvolvimento dos sistemas humano e natural de longo-prazo, dentro de uma visão minimamente ética que considere o componente humano e não humano, os ecossistemas e as futuras gerações. E, tratando-se da evolução de longo prazo de um sistema altamente complexo como o do planeta Terra, que engloba a população humana e a economia, além dos ecossistemas e fluxos biogeoquímicos, a tarefa dos indicadores é reduzir as incertezas decorrentes dessa complexidade, uma vez que, pelo menos a curto prazo, 
não seremos capazes de eliminá-las por completo. A construção desses indicadores deve ser baseada na compreensão da necessidade de um sistema sócio-econômico que melhore a qualidade da vida humana e preserve a capacidade de suporte dos sistemas naturais.

Ainda de acordo com Meadows, um sistema de informações adequado deve apresentar três principais medidas agregadas de desenvolvimento sustentável: a suficiência com a qual as metas finais, traduzidas no bem-estar, são levadas a todos; a eficiência com a qual os meios finais, representados pelo capital natural, são transformados em metas finais; e a sustentabilidade do uso do capital natural. Nesse sentido, um indicador de desenvolvimento sustentável deve avaliar eficiência, suficiência, equidade e qualidade de vida.

Segundo BOSSEL (1999), os indicadores precisam prover todas a informações essenciais sobre a viabilidade de um sistema e sua taxa de mudança, bem como indicar sua contribuição para o objetivo total do desenvolvimento sustentável, missão que exige um modelo razoavelmente detalhado do sistema completo e de seus componentes. Para tanto, três tarefas são necessárias: identificar os sistemas e subsistemas principais que são relevantes no contexto do desenvolvimento sustentável; encontrar indicadores essenciais para o desempenho de cada sistema e sua contribuição para os outros sistemas, desenvolvendo uma abordagem para identificar indicadores de viabilidade e sustentabilidade desses sistemas; e pensar sobre como usar essa informação para avaliar viabilidade e sustentabilidade do desenvolvimento humano nos diferentes níveis de organização da sociedade.

Os indicadores essenciais, afirma Bossel, "são aqueles que fornecem uma descrição completa do estado de satisfação dos interesses fundamentais de cada sistema, isto é, seus orientadores básicos: existência, efetividade, liberdade de ação, segurança, adaptabilidade, coexistência e necessidades psicológicas", tanto para os seres humanos quanto para os sistemas dos quais os humanos são componentes (p. 108).

O importante, segundo BELLEN (2005) é que os indicadores sejam holísticos, retratando o sistema total e não apenas elementos e interconexões dos subsistemas. 
Das várias experiências citadas, depreende-se que parece haver um certo consenso quanto ao fato de que os indicadores devem ser capazes de capturar todos os aspectos importantes do desenvolvimento sustentável e permitir a avaliação contínua das ações implementadas. Outro aspecto importante sobre o qual também parece haver consenso é que o processo de desenvolvimento e melhoria contínua de indicadores deve ser sempre participativo.

\subsubsection{Experiências do Brasil}

No Brasil destaca-se o trabalho desenvolvido pelo Instituto Brasileiro de Geografia e Estatística (IBGE), que enfrentou o desafio de tentar retratar as diversas dimensões da diversidade que caracteriza o país.

O trabalho do IBGE teve como base o documento "Indicadores de desenvolvimento sustentável: marco e metodologias", publicado em 1996 pela Comissão para o Desenvolvimento Sustentável (CDS) das Nações Unidas, conhecido como "Livro Azul", e as recomendações adicionais que o sucederam, com as adaptações necessárias às particularidades brasileiras.

O resultado desse trabalho foi a publicação, em 2002, do documento "Indicadores de Desenvolvimento Sustentável: Brasil 2002", contendo 50 indicadores, organizados em quatro dimensões: social, ambiental, econômica e institucional.

Os indicadores foram organizados em fichas, contendo a descrição de sua construção, sua justificativa, vínculos com o desenvolvimento sustentável e explicações metodológicas. O trabalho traz, ainda, tabelas, figuras, gráficos e mapas ilustrativos, expressando a evolução recente dos indicadores e diferenciações no território nacional (IBGE, 2002).

Em 2004, o IBGE, dando continuidade ao trabalho lançado em 2002, publicou o documento "Indicadores de Desenvolvimento Sustentável: Brasil 2004", no qual foram introduzidos novos indicadores, sendo alguns deles revistos, ampliados, aprimorados ou condensados, além de ter havido supressões e substituições, passando de 50 para 59 indicadores, mantida a organização nas dimensões social, ambiental, econômica e institucional. 
As principais inovações da publicação de 2004 foram a introdução de uma matriz de relacionamentos, ilustrando as ligações existentes entre os diferentes indicadores, além de um resumo gráfico e um apêndice que traz as informações ordenadas segundo as diretrizes de equidade, eficiência, adaptabilidade e atenção a gerações futuras.

No trabalho do IBGE, a dimensão ambiental dos indicadores de desenvolvimento sustentável corresponde ao uso dos recursos naturais e à degradação ambiental e sua relação com os objetivos de preservação e conservação do meio ambiente. A dimensão social diz respeito aos objetivos relacionados à satisfação das necessidades humanas, melhoria da qualidade de vida e justiça social, enquanto que a dimensão econômica trata do desempenho macroeconômico e financeiro e dos impactos no consumo de recursos materiais e uso de energia primária, objetivando a eficiência dos processos produtivos e as alterações nas estruturas de consumo. A dimensão institucional diz respeito à orientação política, bem como à capacidade e esforço despendido para as mudanças exigidas para a implementação efetiva do desenvolvimento sustentável (IBGE, 2004).

Bastante recente é o sistema de indicadores proposto pelo Núcleo de Estudos de Políticas Públicas (NEPP), da Unicamp, em 2004, denominado DNA-Brasil. Elaborado com a finalidade de visualizar a realidade por meio de indicadores integrando diversas dimensões, comparar a realidade brasileira com as expectativas de futuro e com a situação de outros países e balizar a mobilização de atores públicos e privados envolvidos em projetos de desenvolvimento, utiliza 24(vinte e quatro) indicadores referentes a 07(sete) dimensões: bem-estar econômico, competitividade econômica, condições sócio-ambientais, educação, saúde, proteção social básica e coesão social.

Para a dimensão bem-estar econômico foram selecionados quatro indicadores: renda per capita e sua distribuição inter-regional; relação entre as remunerações médias das mulheres e dos homens; relação entre as remunerações médias de negros e brancos; e taxa de ocupação formal. A dimensão competitividade econômica traz o indicador exportações mundiais: evolução da participação do Brasil, com destaque para os produtos/setores de média e alta intensidade tecnológica. Na dimensão condições sócio-ambientais estão os seguintes indicadores: 
instalações adequadas de esgotamento sanitário; destino adequado do lixo urbano; e tratamento do esgoto sanitário. A dimensão educação abriga os indicadores taxa de escolarização líquida no ensino médio; concluintes do ensino médio na idade esperada; e desempenho do aluno no PISA - Programa Internacional para Avaliação do Estudante. Para a dimensão saúde foram selecionados três indicadores: anos potenciais de vida perdidos; mortalidade infantil; e coeficientes de mortalidade por acidentes cardiovasculares (ACV's) e acidentes vasculares cerebrais (AVC's). A dimensão proteção social básica traz os indicadores cobertura previdenciária para maiores de 65 anos e financiamento da atenção à saúde e, por último, a dimensão coesão social integra os indicadores distribuição de renda interpessoal; morte por homicídio em homens, na faixa de 15 a 24 anos; percentual de adolescentes que são mães; e justiça tributária.

O DNA-Brasil definiu uma forma geométrica para sintetizar a comparação das dimensões incluídas no estudo, baseada em projeções feitas por participantes de uma reunião organizada pelo Instituto DNA Brasil em outubro de 2004, às quais foi atribuído o valor 1. Situações piores para um mesmo indicador brasileiro definem valores inferiores a 1. Situações melhores, se houver, definem valores maiores que 1.

Figura 1 - Índice DNA-Brasil 2005.

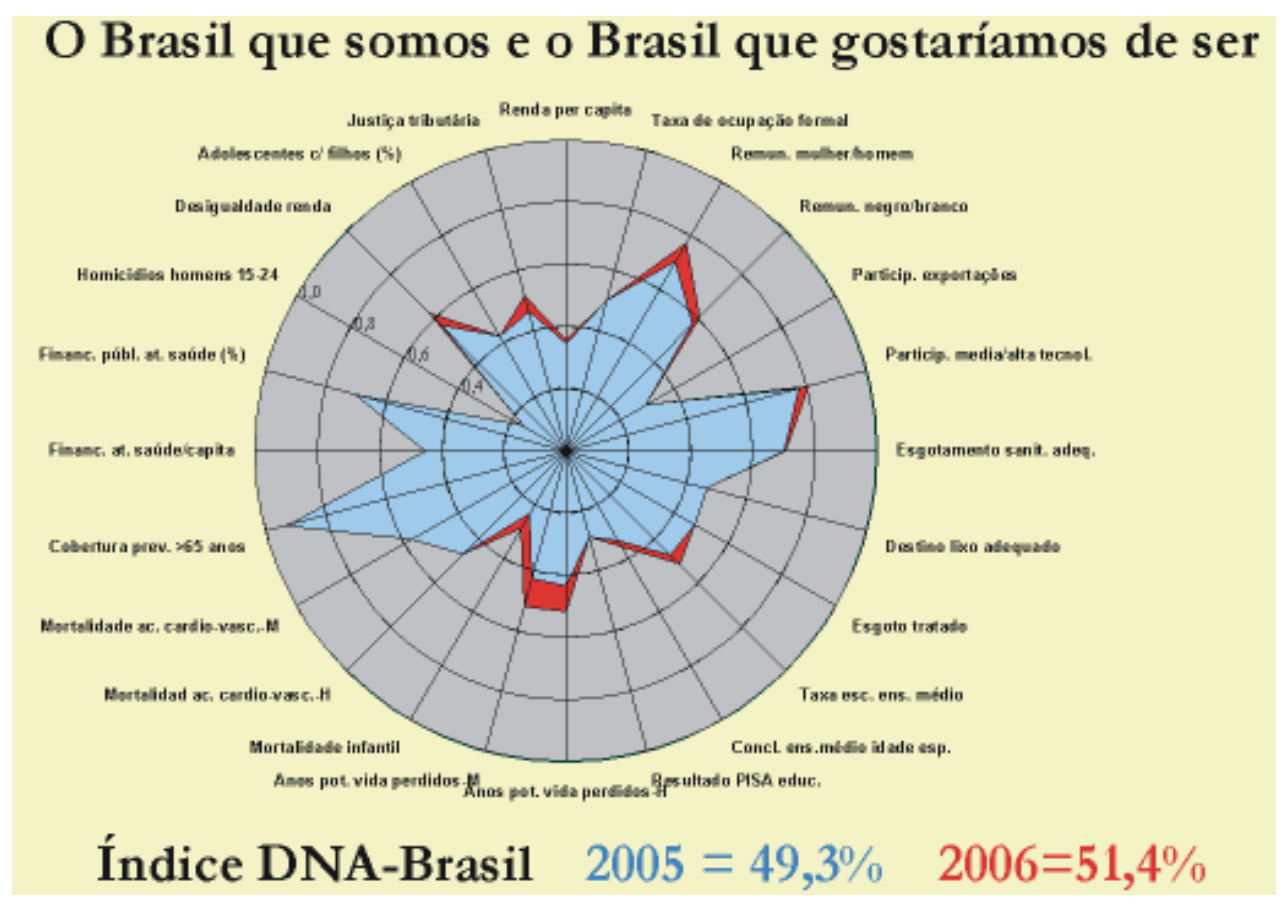

Fonte: NEPP, 2006. 
O objetivo último do DNA-Brasil é criar uma mobilização nacional em torno de um projeto de desenvolvimento social e econômico para o país, ressaltando as dimensões problemáticas, sem deixar de considerar as dimensões demográficas, buscando estabelecer com o máximo rigor e cientificidade possíveis parâmetros que poderão orientar a formulação de políticas e a ação de atores individuais e institucionais (NEPP, 2006).

No âmbito do Estado de São Paulo, foi instituído pela Lei Estadual no 10.765 , de 19/02/2001, como uma ferramenta para avaliação e redirecionamento dos recursos públicos voltados para o desenvolvimento dos municípios paulistas, o Índice Paulista de Responsabilidade Social (IPRS).

O sistema de indicadores que compõe o IPRS foi originalmente proposto no âmbito do Fórum São Paulo Século XXI, pela Assembléia Legislativa do Estado de São Paulo, e desenvolvido pela Fundação SEADE (Fundação Sistema Estadual de Análise de Dados), tendo como objetivo expressar o grau de desenvolvimento social e econômico dos 645 municípios do Estado, e vem se mostrando como um importante instrumento de diagnóstico da situação dos municípios e avaliação dos resultados da ação pública em todo o Estado, subsidiando a formulação e a avaliação das políticas públicas na esfera municipal.

O Índice Paulista de Responsabilidade Social (IPRS) foi desenvolvido em consonância com o paradigma do desenvolvimento humano proposto pelo Programa das Nações Unidas para o Desenvolvimento (PNUD) e utiliza três dimensões na sua construção: longevidade, educação e riqueza municipal, incorporando, ainda, variáveis de resultado e esforço.

O IPRS, preservando os componentes do IDH (Índice de Desenvolvimento Humano), ou seja, renda, longevidade e conhecimento, os adaptou à realidade paulista e aos objetivos do projeto, que também deveria contemplar variações de curto prazo e os esforços dos municípios. Além disso, houve necessidade de trabalhar com um número reduzido de variáveis, condicionadas às condições de consistência e disponibilidade para todos os municípios.

Os indicadores do IPRS foram estruturados de maneira a possibilitar captar a situação atual dos municípios, comparar resultados e esforços, aferir os efeitos da 
participação social e captar o efeito de variações ao longo do tempo (FUNDAÇÃO SEADE, 2001).

Resultado interessante dessa iniciativa foi o desenvolvimento do Índice Paulista de Vulnerabilidade Social (IPVS), diante da constatação de que o IPRS não respondia integralmente às questões de equidade e de pobreza existentes no interior dos municípios, já que, como um indicador agregado, não revelava as diferentes condições de vulnerabilidade de expressivos segmentos populacionais existentes em seus territórios: os denominados 'bolsões de pobreza', resultado de um padrão de crescimento das cidades que, ao longo dos anos, não têm sido capazes de incorporar parcelas significativas de suas populações aos benefícios do desenvolvimento, cenário observado em todo o Brasil, em especial nos grandes centros urbanos.

Adotando como unidade dessas áreas o setor censitário produzido no âmbito do Censo demográfico de 2000, o indicador resultante consiste em uma tipologia derivada da combinação entre as dimensões sócio-econômica e demográfica, que classifica o setor censitário em seis grupos de vulnerabilidade social: nenhuma vulnerabilidade, vulnerabilidade muito baixa, vulnerabilidade baixa, vulnerabilidade média, vulnerabilidade alta e vulnerabilidade muito alta.

Tabela 2- Índice Paulista de Vulnerabilidade Social

\begin{tabular}{cccc}
\hline \multirow{2}{*}{ Grupo } & \multicolumn{2}{c}{ Dimensões } & \\
\cline { 2 - 4 } & Socioeconômica & Ciclco de Vida Familiar & IPVS \\
\hline 1 & Muito Alta & Famílias Jovens, Adultas ou Idosas & Nenhuma Vulnerabilidade \\
\hline 3 & Média ou Alta & Famílias Idosas & Vulnerabilidade Muito Baixa \\
& Alta & Famílias Jovens e Adultas & Vulnerabilidade Baixa \\
4 & Média & Famílias Adultas & Vulnerabilidade Média \\
\hline 6 & Baixa & Famílias Jovens & Vulnerabilidade Alta \\
\hline
\end{tabular}

Fonte: FUNDAÇÃO SEADE, acesso em 2007.

A dimensão sócio-econômica compõe-se da renda apropriada pelas famílias e do poder de geração da mesma por seus membros. A dimensão demográfica está 
relacionada ao ciclo de vida familiar. As efetivas condições de vida e possibilidades de mobilidade social são definidas, assim, pelo confronto entre as características individuais e familiares - ciclo de vida, tipo de arranjo familiar, escolaridade, renda corrente, formas de inserção no mercado de trabalho e condições de saúde - e suas possibilidades de desfrute dos bens e serviços ofertados pelo Estado, sociedade e mercado.

O Índice Paulista de Vulnerabilidade Social permite ao gestor público e à sociedade uma visão mais detalhada das condições de vida do seu município, com a identificação e a localização espacial das áreas que abrigam os segmentos populacionais mais vulneráveis à pobreza, aspecto fundamental tanto para as políticas públicas emergenciais de combate à pobreza, quanto para aquelas de caráter universal e de médio e longo prazos, que objetivam a diminuição das desigualdades sociais (FUNDAÇÃO SEADE, 2007).

Outros importantes trabalhos existem, que não serão aqui mencionados por não ser este o objetivo desta pesquisa, como por exemplo, ainda no âmbito do Estado de São Paulo, o Índice de Salubridade Ambiental (ISA), desenvolvido pelo Conselho Estadual de Saneamento (CONESAN) para a medição das condições de saneamento dos municípios do Estado, além de diversas iniciativas no âmbito dos Estados e municípios por todo o Brasil.

\subsection{SITUAÇÕES SIMILARES EM OUTROS PAÍSES}

Neste item são apresentadas três situações de poluição ambiental ocorridas em outros países, que exigiram medidas de controle, apontando-se as soluções adotadas em cada situação. O primeiro caso (2.4.1.) ocorreu nos Estados Unidos e versa sobre a contaminação por resíduos industriais químicos do solo e águas subterrâneas de uma área industrial que, posteriormente, foi ocupada por moradias. As duas outras situações dizem respeito ao controle da poluição do ar na Inglaterra (2.4.2.) e à experiência do Japão no controle da poluição ambiental, a partir do início dos anos 1970 (2.4.3.). 


\subsubsection{O Caso de Love Canal, nos Estados Unidos}

O caso de Love Canal é tido como uma das mais terríveis tragédias ambientais da história norte-americana. Essa área, situada em Niagara Falls, New York, foi, por aproximadamente dez anos, utilizada como aterro de resíduos industriais químicos. Em 1953, a empresa Hooker Chemical Company, proprietária da área e responsável pela operação do aterro, cobriu o canal com terra e vendeu a área à cidade. No final dos anos 50, aproximadamente 100 casas e uma escola haviam sido construídas no local, instalando-se ali uma comunidade de trabalhadores.

Contudo, uma matéria publicada no jornal New York Times, no dia $1^{\circ}$ de agosto de 1978, vinte anos depois da empresa Hooker Chemical Company encerrar o uso de Love Canal como um aterro industrial, noticiava que a ocorrência de uma quantidade recorde de chuvas na área revelara um desastre: 82 diferentes substâncias químicas, 11 delas suspeitas de serem carcinogênicas, estavam brotando através do solo, diante do rompimento dos recipientes que as continham, escorrendo pelos quintais e sob a base das 100 casas e da escola pública construídas ao longo do canal (BECK, 1979).

Nessa época, segundo o autor, tambores corroídos de resíduos podiam ser vistos brotando do solo dos quintais, nas bases das casas e no solo da escola, assim como poças de substâncias nocivas, causando a morte de árvores e jardins. Em toda parte, havia um forte e desagradável odor no ar e as crianças apresentavam lesões nas faces e nas mãos. O local apresentava, também, alta taxa de abortos, bem como nascimentos de crianças com defeitos, objeto de investigação pelo Departamento de Saúde do Estado de Nova Iorque. Um grande percentual dos moradores apresentava, ainda, contagem alta de glóbulos brancos, um possível precursor de leucemia, fato objeto de acompanhamento.

Dentre as substâncias químicas detectadas na área, o benzeno apresentava alta concentração e era uma das mais prevalecentes, substância essa conhecida por ser carcinogênica para os seres humanos. Essa situação levou à necessidade de evacuação imediata da área, com a remoção de 221 famílias, sendo as casas adquiridas pelo governo do Estado. O governo federal aprovou, no mesmo período, 
um fundo emergencial de ajuda financeira para Love Canal, visando amenizar as conseqüências do desastre ambiental.

$\mathrm{Na}$ seqüência, foram implementados procedimentos técnicos visando à descontaminação do local, que se basearam, inicialmente, em um sistema de barreira para interceptar a migração dos contaminantes na água subterrânea, bem como sistema de coleta e tratamento dessa água, além da colocação de manta protetora sobre o solo contaminado e isolamento do local. Os sistemas implantados, segundo monitoramento realizado pela United States Environmental Protection Agency (EPA) em 1980, eram eficientes, resultando no confinamento dos contaminantes no próprio local e redução do teor destes no solo e na água subterrânea, que era desviada e tratada. Entretanto, esse estudo detectou novos locais de contaminação que precisavam ser recuperados, dentre os quais tubulações, sedimentos de cursos d'água, e algumas áreas próximas ao Rio Niágara (EPA, 1987).

Assim, medidas adicionais de recuperação da área tiveram que ser adotadas. A definição das medidas necessárias, conforme a EPA (1987), demandou a realização de diversos estudos específicos, sendo mantido o monitoramento da água subterrânea para assegurar que as ações adotadas eram adequadas à proteção da saúde pública e do meio ambiente.

Várias ações realizadas para a recuperação da área de Love Canal resultaram de acordos de cooperação entre o Departamento de Conservação Ambiental do Estado de Nova Iorque e a Agência de Proteção Ambiental dos Estados Unidos (EPA), com o comprometimento de milhões de dólares, disponibilizados especialmente por um programa do governo federal criado em 1980, justamente para atender casos de depósitos de resíduos perigosos abandonados, conhecido como Superfund. Segundo BECK (1979), houve grande cooperação dos governos local, estadual e federal, os quais responderam rapidamente com medidas para a solução do problema, em especial disponibilizando ajuda financeira.

Ao longo dos anos, novas medidas tiveram quer ser adotadas, dentre as quais a destruição termal, no próprio local, de sedimentos e outros materiais contaminados por dioxinas, com a disposição dos resíduos não perigosos resultantes do tratamento no próprio site. Cerca de dez anos depois, aproximadamente 1000 famílias tinham sido relocadas da área e suas casas demolidas (EPA, 1987). 
Somente em setembro de 2004, a EPA decidiu retirar a área de Love Canal da lista nacional de prioridades do Superfund, uma vez que todo o trabalho de limpeza do local tinha sido completado, sendo que o monitoramento realizado durante quinze anos, e ainda em continuidade, revelava que os objetivos de remediação haviam sido alcançados, tornando-se a área um símbolo do sucesso do fundo criado com esse fim (EPA, 2004).

Ainda conforme a EPA, com a recuperação da área, bairros situados no entorno de Love Canal foram revitalizados, porém o monitoramento do local não foi encerrado, a fim de permitir a adoção das medidas necessárias caso venha a ocorrer alguma mudança em suas condições.

\subsubsection{O Controle da Poluição na Inglaterra}

$\mathrm{Na}$ Inglaterra, foram verificados efeitos adversos da poluição do ar sobre a saúde da população desde os anos 1840, surgindo diversas iniciativas para introduzir no país leis que obrigassem as indústrias a reduzirem as emissões de poluentes, destacando-se nesse período a edição do Ato de Saúde Pública, em 1848, e do primeiro Alkali Act, em 1863. Nessa época, foram identificados diversos problemas nas regiões próximas às plantas industriais, decorrentes das emissões de poluentes do ar que, além de danos à saúde, causavam extensos danos à vegetação.

Em 1874 foi editada norma que exigia que as indústrias adotassem as melhores práticas disponíveis para a redução da poluição, a qual fundamentaria a política de poluição do ar na Inglaterra nos próximos 100(cem) anos. Houve grande resistência das indústrias em atender à legislação, sendo que até o início da década de 1970 poucos resultados efetivos haviam sido obtidos. Esse fato decorreu, principalmente, de uma interpretação muito liberal dada à norma, segundo a qual bastava que as indústrias demonstrassem ter utilizado a melhor opção de prática disponível para controlar as emissões ou a melhor opção que não implicasse em custos excessivos, para que punições não fossem aplicadas, mesmo que esse controle não fosse obtido (SAINT ANDREWS UNIVERSITY, acesso em 2007).

A par disso, embora houvesse evidências de que as emissões domésticas eram o principal problema de poluição do ar no país, os governantes se recusavam a abordar a questão, por falta de apoio popular. Somente em 1952, quando uma forte 
nuvem de poluição, conhecida como Great London Smog, cobriu Londres por cinco dias, durante os quais o número de mortes por doenças respiratórias excedeu em 4.000 o número verificado em condições normais, com forte repercussão na mídia, a sociedade se posicionou a favor de um controle mais forte da poluição, surgindo, então, o apoio necessário à adoção de medidas efetivas de controle da poluição doméstica decorrente do uso de combustíveis fósseis, em especial madeira e carvão (GIUSSANI, 1994).

Segundo a autora, esse evento, somado a muitas campanhas de grupos organizados, fazendo aumentar a consciência pública sobre os efeitos maléficos da poluição do ar, originou um nível tal de pressão sobre os governantes que não era mais possível ignorar a questão. Como resultado dessa pressão, o governo criou um comitê para examinar o problema da poluição do ar, cujo trabalho resultou na introdução de uma norma fundamental para o controle da poluição na Inglaterra: o Clean Air Act [Lei do Ar Limpo], datado de 1956.

Essa legislação foi pioneira em tratar conjuntamente o problema da poluição doméstica e da poluição industrial no país. Suas principais disposições diziam respeito ao controle das emissões domésticas de fumaça preta. Quanto à poluição industrial, referiam-se basicamente à substituição de caldeiras, aumento da altura das chaminés das fábricas e instalação de equipamentos de controle da poluição. $\mathrm{O}$ ato também exigiu que as indústrias instalassem equipamentos para medir suas emissões de fumaça, cujos resultados deveriam ser disponibilizados às autoridades locais. $\mathrm{O}$ monitoramento sistemático da poluição do ar, aliás, somente começou a ocorrer no país a partir desse ato, sendo um dos principais passos na direção do controle da poluição.

Ainda segundo GIUSSANI (1994), uma das principais inovações da norma foi a concessão de poder discricionário às autoridades locais para estabelecerem "áreas de controle de fumaça" em seus distritos, nas quais somente poderiam ser utilizados combustíveis que não produzissem fumaça, seguindo um modelo já introduzido por autoridades progressistas de locais como Manchester e Coventry. As autoridades locais também poderiam estabelecer prescrições para o controle das fontes de poluição domésticas e industriais em algumas situações de risco, sendo 
disponibilizados, ainda, recursos financeiros para auxiliar os habitantes dessas áreas a se adequarem à nova legislação.

A implementação da norma, entretanto, não ocorreu da mesma maneira em todas as regiões do país, sendo adotados programas progressivos por autoridades de locais mais ricos, como Londres e Yorkshire, enquanto outros locais responderam mais lentamente ao ato, havendo especial resistência das indústrias de mineração de carvão, que acreditavam que o estabelecimento de áreas de controle restringiria o uso do minério, causando danos à indústria. Por esse motivo, foi fundamental a criação pelo ato de um Conselho para acompanhar o progresso no controle da poluição do ar decorrente do cumprimento da norma. Esse conselho identificou a resistência de algumas autoridades locais para implantar áreas de controle, fato que determinou a edição de um novo Clean Air Act, em 1968, dando ao governo federal o poder de forçar as autoridades locais a tratarem do problema da poluição doméstica. Esse mesmo conselho recomendou que informações sobre a poluição do ar fossem disponibilizadas à população.

Conforme a autora, o ato foi bem sucedido na redução total das emissões domésticas de fumaça, com reflexos positivos na redução das emissões industriais, havendo uma relação estatística entre a redução das emissões domésticas e industriais e as áreas providas de disposições locais de controle, ou seja, quanto maior o número dessas normas, maior a redução das emissões. Houve diversos percalços no cumprimento da norma, como em 1970-1971, quando muitas áreas de controle foram suspensas devido à falta de combustíveis, contribuindo para a piora de episódios de poluição do ar em alguns locais. Apesar desses fatos, ocorreu uma grande mudança no tipo de combustíveis utilizados para fins domésticos, como para cozinhar e no aquecimento, sendo o carvão substituído por gás, eletricidade ou carvão processado, que não emitia fumaça, contribuindo para a redução da poluição urbana, diminuindo as emissões de material particulado e enxofre. Mudanças similares já tinham ocorrido dentro da indústria, sendo que muitas delas, ainda no século XIX, trocaram o uso do carvão como combustível para a energia elétrica. Contribuíram para essa mudança, além da legislação, as aspirações sociais da época e a disponibilidade de opções de aquecedores e fogões menos poluentes, assim como o 
declínio da atividade industrial pesada no país, que era um dos setores econômicos mais poluidores, com o aumento das atividades do setor de serviços.

Desde a edição do Clean Air Act, em 1956, a qualidade do ar na Inglaterra melhorou significativamente, com a redução em 80\%, em 20 anos, da concentração média anual de fumaça nas áreas urbanas, e redução de $70 \%$ da média do nível de concentração de dióxido de enxofre, reduzindo-se proporcionalmente a taxa de mortalidade por doenças respiratórias. As reduções das concentrações desses poluentes foram particularmente significantes nas cidades do norte do país, como Manchester, Barnsley, Glasgow e Stoke on Trent, em razão das normas editadas pelas autoridades locais por força do Clean Air Act, de 1956 (GIUSSANI, 1994).

Contudo, recentemente, os Conselhos de governo desses locais completaram uma revisão e avaliação detalhada da qualidade do ar nessas áreas, o qual revelou que, caso nenhuma ação fosse adotada, haveria aumento da média anual de dióxido de nitrogênio, excedendo em muito os objetivos estabelecidos para a cornubação "Grande Manchester", assim como uma superação, em menor escala, dos objetivos fixados para o material particulado (MAPAC, 2005), revelando a necessidade de vigilância contínua da situação, para possibilitar a adoção das medidas necessárias para a manutenção da qualidade do ar em níveis adequados.

\subsubsection{A Experiência do Japão}

Durante muitos anos o Japão foi mundialmente conhecido como o país mais poluído do mundo, alcançando, porém, conforme MATSUI (1993), progressos marcantes no controle da poluição ambiental durante os anos 1970, período no qual foram adotadas mudanças políticas drásticas, tidas como uma espécie de 'revolução cultural', impulsionadas pela crítica internacional que via o país como o 'paraíso dos poluidores', bem como pelo impacto causado pela crise do petróleo em 1973 e 1979. A crise do petróleo e a poluição ambiental, com sérios efeitos sobre a saúde da população, dentre os quais destaca-se o emblemático caso do "Mal de Minamata" (disfunções cerebrais detectadas em crianças, causadas pela ação do mercúrio, oriundo de uma planta industrial situada na Baía de Minamata), detectado por 
cientistas japoneses no final dos anos 50, fizeram surgir fortes pressões sociais e políticas no país que, conforme o autor, somadas às discussões sobre a problemática ambiental que começavam a se desenvolver em todo o mundo, resultaram na revisão e fortalecimento da legislação sobre controle da poluição no Japão no ano de 1970.

Dentre as diversas ações legislativas adotadas, que significaram uma mudança da política ambiental do país, destacam-se as Leis de Controle da Poluição das Águas e de Controle da Poluição do Ar que, além de estabelecerem padrões e penalidades, possibilitaram aos governos locais o estabelecimento de padrões mais restritivos, caso necessário para o atendimento dos padrões de qualidade ambiental. Merece menção, também, a edição da Lei de Crime de Poluição Ambiental, além de normas sobre saneamento, poluição do solo agrícola, regulação de pesticidas e outras substâncias tóxicas, dentre outras.

Em 1971, foi criada a Agência Ambiental do Japão, vinculada ao escritório do Primeiro Ministro, tendo como funções básicas o controle da poluição ambiental e a conservação da natureza, cabendo-lhe coordenar os programas ambientais do governo em administração e pesquisa. Em 1973, o governo decidiu implementar um procedimento de avaliação de impacto ambiental para projetos públicos com potencial de impacto ambiental significativo, o qual foi posteriormente incorporado em diversas normas. Gradativamente, ao longo dos anos 1970, um conceito holístico de qualidade ambiental se espalhou por todo o Japão, sendo inserido no planejamento do desenvolvimento das comunidades locais, bem como a nível nacional, com preocupações que abrangiam desde os problemas de poluição industrial, poluição sonora, do ar e por vibrações ocasionadas pelos meios de transporte, estendendo-se ao controle das atividades agrícolas e domésticas, especialmente a disposição de resíduos sólidos, economia de energia e conservação da natureza, até a proteção dos bens de valor histórico e cultural, com a criação de diversas normas específicas sobre tais matérias.

No início dos anos 1980, apesar de ter havido uma redução nos esforços até então realizados pelas políticas ambientais, em razão do baixo crescimento econômico e do crescimento do desemprego no país, as práticas de avaliação de impacto ambiental já estavam incorporadas em diversos projetos de desenvolvimento, tais como nos procedimentos de planejamento e implantação de 
estações elétricas, rodovias, aeroportos e ferrovias. A legislação de proteção de lagos contra a eutrofização, bem como a legislação que protegia a população contra a poluição sonora também permaneciam fortes.

Nesse período, começaram a emergir no Japão novas dimensões das políticas ambientais, trazendo, dentre outros aspectos, um novo estilo de desenvolvimento, baseado na melhoria da qualidade de vida por meio de abordagens de situações locais específicas, tendo em vista o desenvolvimento e gerenciamento das comunidades humanas no nível local. Esse novo tipo holístico de abordagem do ambiente humano, iniciado por governadores e prefeitos, que se opunha ao grande projeto nacional baseado na moderna inovação tecnológica, acabou se tornando mais importante no país. Movimentos de cidadãos organizados que, desde o início dos anos 1970, confrontavam com o governo e com as indústrias, acabaram determinando uma maior participação da população na elaboração das políticas ambientais, inclusive naquelas relativas à conservação de florestas e sítios históricos.

No início dos anos 1990, período no qual se destacavam no cenário mundial as questões ambientais globais, como a redução da camada de ozônio, o efeito estufa e a chuva ácida, ocorreu no Japão a revisão da legislação sobre disposição de resíduos, que estabeleceu como objetivos a redução da geração, a reutilização e a reciclagem, tornando-se ferramenta importante para mudar a estrutura da produção industrial e o estilo de vida dos japoneses.

MATSUI (1993) afirma que o sucesso do controle da poluição industrial no Japão pode ser atribuído a cinco fatores: antecedentes sociais, fatores legais, fatores administrativos, fatores financeiros e indústria e negócios ambientais. Os antecedentes sociais incluem os sacrifícios humanos pelo "Mal de Minamata", o "Mal de Itai-Itai", etc, bem como os movimentos sociais de cidadãos organizados contra a poluição, aspecto no qual teve a mídia importante papel educativo. Esses movimentos de cidadãos transformaram as políticas e a aceitação social do controle da poluição no Japão, tornando amplamente aceito pela sociedade o princípio do poluidor-pagador que, somado à Lei de Crime Ambiental, contribuiu para a rápida implementação de medidas de controle da poluição pelo setor industrial do Japão. Uma legislação ambiental forte solidificou as estruturas da administração ambiental no Japão, tanto no nível nacional, quanto no nível local, levando à identificação e 
controle dos principais poluidores em um curto período de tempo. 'Acordos de cavalheiros' estabelecidos entre indústrias e cidadãos contribuíram para prevenir a poluição industrial e manter as atividades sob condições estritas e sempre mais rigorosas e amplas que o simples respeito aos padrões nacionais e locais. Por último, os esforços legais e administrativos acabaram por criar um novo mercado de negócios e indústria ambiental, necessário para dar suporte à operação e manutenção diária dos numerosos equipamentos e sistemas de controle de poluição.

IMURA (1993) também destaca a importância dos movimentos de cidadãos contra a poluição, afirmando que, combinados com as campanhas críticas da mídia, foram fundamentais na aceleração do desenvolvimento e disseminação de medidas regulatórias e de diretrizes de controle da poluição pelos governos central e locais do Japão. Entre essas medidas estão a implementação de diversas regulamentações conforme acima mencionado - e o desenvolvimento de sofisticadas tecnologias, tais como sistemas computadorizados de monitoramento da poluição do ar e métodos de simulação para calcular a difusão de poluentes, especialmente na metade da década de 1970.

A crise do petróleo de 1970, afirma o autor, levou as políticas ambientais do Japão a uma nova fase, uma vez que o aumento dos preços do petróleo acelerou os esforços para economia de energia, reestruturando o setor industrial, com o favorecimento de setores menos dependentes de energia, tais como indústrias de eletrônicos, computadores e comunicações. Após 1987, entretanto, devido à contínua expansão da economia japonesa, o consumo de energia voltou a crescer rapidamente, no mesmo momento em que cresciam no mundo todo as preocupações com as questões globais de meio ambiente. A partir de 1992, com a realização da Conferência das Nações Unidas sobre Meio Ambiente e Desenvolvimento, no Rio de Janeiro, a ampliação das discussões da interdependência econômica e ambiental em um contexto global fez ressaltar o senso de responsabilidade e o papel dos países para a proteção do meio ambiente, assim como gerou uma maior preocupação das pessoas com as questões ambientais globais e uma maior reflexão dos cidadãos a respeito de seu estilo consumista de vida. Nesse contexto, o escopo das políticas ambientais do Japão vem sendo ampliado, com a adoção de programas voltados para os problemas ambientais globais, uma vez que estes estão muito mais relacionados 
ao modo de vida, cultura, tecnologia e valores sociais de nossa civilização que os problemas tradicionais de poluição, nos quais poluidores e vítimas eram claramente identificados, bastando controlar e monitorar as emissões de poluentes de fábricas e plantas.

A solução dos problemas ambientais atuais, que alcançam escala regional ou global, afirma Imura, "exige uma reestruturação revolucionária da sociedade" (p. 77), na qual a inovação tecnológica não é suficiente. Essa reestruturação passa pela revisão do processo de urbanização e melhoria da eficiência energética nos setores residencial, comercial e de transportes, dentre outros aspectos, mas principalmente pela incorporação de novos valores na vida diária da população e nos negócios, com a criação de uma cultura baseada em uma ética ambiental.

As medidas formais de controle da poluição no Japão foram baseadas em uma combinação de regulamentação e tecnologias de controle. O governo estabeleceu metas a serem cumpridas pelas indústrias que, a princípio, pareciam ser extremamente difíceis de serem atingidas. Contudo, além de propor soluções técnicas, o governo permitiu que as empresas desenvolvessem seus próprios métodos de solução, favorecendo a inovação tecnológica, pelo estímulo à competição para o desenvolvimento tecnológico entre as indústrias.

Assim, ocorreram grandes mudanças de atitudes por parte das indústrias japonesas, que incorporaram a preocupação com as questões ambientais, inclusive globais, em suas atividades e passaram a direcionar suas ações para a proteção do meio ambiente global, embora não esteja claro se essas mudanças ocorreram em razão de interesses capitalistas, face à criação de um mercado ambiental, ou por preocupações éticas com a proteção do planeta Terra.

Os valores e comportamento dos consumidores, ainda segundo Imura, também têm mudado, pela conscientização de que o incessante desejo de obtenção de bens materiais é o principal responsável pela degradação dos recursos naturais e pelos problemas ambientais. Conforme pesquisas realizadas no país no ano de 1990, informa o autor, uma grande parte da população prefere a proteção ambiental ao crescimento econômico, sendo que $35 \%$ das pessoas estão dispostas a pagar o custo da proteção ambiental. 
Os esforços para o controle da poluição, portanto, forçaram o setor industrial japonês a melhorar a eficiência da sua produção, por meio de controle de qualidade de produtos e processos, desenvolvimento de tecnologias menos poluentes e de práticas de controle ambiental, dentre outras medidas, levando as indústrias japonesas a terem uma forte posição no mercado internacional. O movimento popular anti-poluição ocorrido no Japão contribuiu, ainda, para o desenvolvimento da democracia no país após a Segunda Guerra Mundial.

No seu desenvolvimento industrial, o Japão enfrentou diversos problemas de poluição, tendo o conceito contemporâneo de política ambiental se iniciado por meio da autonomia local e ação pública organizada contra a poluição ambiental no período pós-guerra. E, "embora os sistemas legislativo e institucional do governo central e dos governos locais, juntamente com as descobertas científicas e novas tecnologias, sejam importantes no controle da poluição ambiental, a conscientização do problema e de seus riscos por parte do público tem sido mais importante", afirma MATSUI (1993, p. 51).

Muitos problemas ambientais ainda não foram solucionados no país, tais como a poluição do ar por veículos automotores e a poluição das águas de rios e lagos, "exigindo o estabelecimento de um sistema econômico e social mais amigo do meio ambiente" (IMURA, 1993, p. 60). A característica mais peculiar da poluição veicular, afirma o autor, é que, nesse caso, poluidores e vítimas não podem ser claramente distinguidos, bem como que a sociedade como um todo é responsável pela causa e pela solução do problema, que passa necessariamente pela mudança do estilo de vida dos cidadãos e pela reforma do sistema de transportes. 


\section{OBJETIVOS}

\subsection{OBJETIVO GERAL}

Descrever a evolução do controle da poluição em Cubatão, do início da implementação do Programa de Controle da Poluição Ambiental no município, no ano de 1983, até o ano de 2005, apontando os resultados alcançados sob o enfoque do desenvolvimento sustentável, por meio de indicadores ambientais, econômicos, sociais e institucionais.

\subsection{OBJETIVOS ESPECÍFICOS}

1. Avaliar o papel desempenhado pelos atores envolvidos na evolução do controle da poluição em Cubatão;

2. Obter a visão desses atores sobre os principais fatores determinantes da evolução do controle da poluição no município;

3. Identificar os principais instrumentos utilizados no processo de melhoria das condições do meio ambiente no município;

4. Avaliar a suficiência e adequação do sistema de informações existente para a correta avaliação do progresso do município na direção do desenvolvimento sustentável;

5. Avaliar a possibilidade de proposição de indicadores;

6. Identificar a visão da coletividade sobre a gestão ambiental do pólo industrial de Cubatão desenvolvida nos anos mais recentes do período da pesquisa e obter eventuais propostas de melhoria. 


\section{METODOLOGIA}

A presente pesquisa é classificada como descritiva que, segundo GIL (2002), tem como objetivo primordial a descrição das características de determinada população ou fenômeno ou, então, o estabelecimento de relações entre variáveis.

A pesquisa desenvolveu-se em três fases distintas, que são descritas separadamente neste capítulo.

\subsection{LEVANTAMENTO BIBLIOGRÁFICO}

$\mathrm{Na}$ fase inicial, prevaleceu a pesquisa bibliográfica e documental. A primeira é aquela desenvolvida a partir de materiais já elaborados sobre um tema alvo de estudo (SPÍNOLA, 2005), enquanto a pesquisa documental se refere à coleta de dados por informações registradas em documentos que ainda não receberam tratamento analítico ou que ainda podem ser reelaborados de acordo com o objeto da pesquisa (GIL, 2002).

Nessa fase foi efetuado levantamento bibliográfico visando obter sustentação teórica e embasamento conceitual para a realização da pesquisa, que envolveu os temas considerados mais relevantes. O levantamento bibliográfico abordou os seguintes tópicos: a) o processo político de conscientização mundial sobre a necessidade do desenvolvimento sustentável e as diferentes abordagens conceituais dessa expressão; b) a importância da informação por meio de indicadores no processo de implementação do desenvolvimento sustentável e na gestão ambiental e as limitações no processo de construção de indicadores de desenvolvimento sustentável, identificando-se experiências internacionais e nacionais; c) o conceito de políticas públicas ambientais, a importância de sua criação, seus principais instrumentos de implementação e a experiência do Brasil; d) o conceito de gestão ambiental pública, abordagens de gestão ambiental nas indústrias e dos principais modelos práticos dessa gestão.

Foi efetuado, ainda, levantamento bibliográfico específico sobre o município de Cubatão, suas características gerais, histórico da implantação do pólo industrial e 
o contexto de degradação ambiental que levou à criação e início da implementação do Programa de Controle da Poluição Ambiental pela CETESB, em 1983, descrevendo-se o conteúdo deste, seus principais objetivos e as ações previstas e realizadas.

Foram trazidas, também, por meio de levantamento bibliográfico, algumas experiências de outros países versando sobre casos similares.

O levantamento bibliográfico foi desenvolvido com base em material já elaborado, partindo, portanto, de dados secundários disponíveis em livros de leitura corrente, de referência informativa e remissiva, publicações periódicas em revistas e jornais científicos, assim como publicações em formato eletrônico. Também foram utilizados como fontes de pesquisa, nesta fase, diversos documentos, especialmente relatórios técnicos da CETESB.

\subsection{SELEÇÃO DE INDICADORES}

$\mathrm{Na}$ segunda fase, foram definidos os indicadores a serem considerados na pesquisa, adotando-se como referencial os indicadores desenvolvidos pela Comissão de Desenvolvimento Sustentável (CDS) das Nações Unidas, baseados em quatro dimensões: ambiental, social, econômica e institucional.

Tendo em vista que um dos objetivos da pesquisa é descrever os resultados alcançados na evolução da execução do Programa de Controle da Poluição Ambiental em Cubatão, os indicadores ambientais foram definidos levando-se em consideração o objetivo básico do projeto de controle, em sua fase inicial, ou seja, reduzir as emissões de poluentes do ar e águas das fontes existentes na região, de modo a garantir o atendimento aos respectivos padrões de qualidade, assim como garantir coleta, transporte e destinação final adequados para os resíduos sólidos (CETESB, 1985b).

Na definição dos indicadores ambientais relacionados à poluição do ar e das águas, e coleta dos dados respectivos, optou-se por utilizar os dados publicados anualmente pela CETESB nos relatórios de qualidade do ar e relatórios de qualidade das águas interiores no Estado de São Paulo, respectivamente, ou seja, dados secundários, uma vez que, além de trazerem as informações sistematizadas, ano a 
ano, tratam-se das informações oficiais disponíveis à sociedade para a avaliação da evolução do programa, bem como do contexto ambiental do município.

Nessa fase, assim como em outros momentos, foi necessário a obtenção de esclarecimentos junto à CETESB, para superar algumas dificuldades encontradas e melhor orientar a execução da pesquisa. Em uma dessas oportunidades, obteve-se a informação de que, diversamente do que ocorre em relação ao ar e às águas, a CETESB não faz levantamento periódico sobre a coleta, transporte e destinação final adequados para os resíduos sólidos industriais gerados no município, não possuindo, portanto, essas informações sistematizadas, mas tão-somente quanto à geração e destinação de resíduos sólidos domésticos. Por esse motivo, não foi possível avaliar os resultados alcançados pelo programa quanto à coleta, transporte e destinação final adequados para os resíduos sólidos industriais gerados no município, conforme previsto originalmente no projeto de pesquisa.

Assim, foram definidos os seguintes indicadores ambientais como suficientes para a avaliação dos resultados alcançados na evolução da execução do Programa de Controle da Poluição Ambiental em Cubatão:

a) quantidade de emissões dos poluentes atmosféricos material particulado (MP), dióxido de enxofre $\left(\mathrm{SO}_{2}\right)$, óxidos de nitrogênio $\left(\mathrm{NO}_{\mathrm{x}}\right)$ e hidrocarbonetos (HC);

b) distribuição anual do índice geral de qualidade do ar em Cubatão-Centro e Cubatão-Vila Parisi;

c) distribuição anual da qualidade do ar em Cubatão-Centro para os parâmetros ozônio $\left(\mathrm{O}_{3}\right)$ e partículas inaláveis $(\mathrm{PI})$;

d) distribuição anual da qualidade do ar em Cubatão-Vila Parisi para o parâmetro partículas inaláveis (PI);

e) índice anual de qualidade das águas (IQA 20\%) para os três principais rios do município: Rio Cubatão, Rio Mogi e Rio Piaçaguera.

Os parâmetros $\mathrm{MP}, \mathrm{SO}_{2}, \mathrm{NO}_{\mathrm{x}}$ e $\mathrm{HC}$ foram priorizados por se tratarem dos principais poluentes atmosféricos objeto de acompanhamento pelo órgão ambiental, considerados internacionalmente, na avaliação da qualidade do ar, ao lado do monóxido de carbono e dos oxidantes totais, como os "mais significativos de uma "condição geral de poluição atmosférica", segundo o conceito de indicadores, 
utilizado em qualquer sistema destinado à detecção de anomalias” (BRANCO, 1984, p. 66). Também foram utilizados a distribuição da qualidade do ar e o índice de qualidade das águas, em razão do objetivo básico do projeto de controle, conforme mencionado acima, somado ao fato desses indicadores facilitarem o entendimento dos resultados.

A escolha da distribuição anual da qualidade do ar em Cubatão-Centro para os parâmetros ozônio $\left(\mathrm{O}_{3}\right)$, que representa a quantidade total de oxidantes existentes no ar, e partículas inaláveis (PI) e, em Cubatão-Vila Parisi, para o parâmetro partículas inaláveis (PI), foi determinada pelo fato desses poluentes serem os mais problemáticos no controle da poluição do ar em Cubatão, nas respectivas bacias aéreas. A divisão em bacias aéreas, por seu turno, se deve ao fato dos índices de qualidade do ar e dos estudos meteorológicos realizados no início do programa terem evidenciado a existência de duas bacias aéreas distintas no município, denominadas “Cubatão-Centro" e "Cubatão-Vila Parisi”, que apresentam características peculiares, não havendo comunicação entre elas em termos de poluição atmosférica. Por esse motivo, os resultados obtidos no controle da poluição do ar no município são apresentados separadamente em relação a cada uma das bacias aéreas (CETESB, 1986).

O conceito de bacias aéreas é utilizado na gestão da qualidade do ar por analogia à bacia hidrográfica, correspondendo a área em que o relevo, as correntes eóleas e o fenômeno de dispersão dos poluentes do ar determinam a extensão dos impactos diretos e indiretos das atividades humanas na qualidade do ar (FEEMA, 2004). O art. 20, $\S 2^{\circ}$, do Decreto Estadual $n^{\circ} 8.468 / 76$, permite a divisão de qualquer Região de Controle de Qualidade do Ar do Estado de São Paulo em sub-regiões, constituídas de um, de dois ou mais municípios, ou, ainda, de parte de um ou de partes de vários municípios, para fins de execução de programas de controle da poluição do ar.

As emissões de monóxido de carbono (CO) não foram utilizadas na pesquisa, uma vez que somente a partir do ano de 1998 suas emissões passaram a ser estimadas e consideradas nos relatórios de qualidade do ar da CETESB para o município de Cubatão. No que se refere ao Índice de Qualidade das Águas (IQA), foi escolhido um ponto em cada um dos três principais rios do município. Para o Rio 
Cubatão, foram privilegiados os resultados de qualidade das águas no ponto de coleta CUBA03900, situado junto à ponte da estrada de ferro Santos-Jundaí, 1,5 Km a jusante da confluência do Rio Perequê com o Rio Cubatão, em razão de se tratar do ponto que apresenta a pior situação nesse curso d'água, por estar a jusante de algumas indústrias e bairros residenciais estabelecidos em suas margens. Nos Rios Mogi e Piaçaguera o monitoramento das águas é efetuado somente em um ponto.

O Índice de Qualidade de Água Bruta para fins de Abastecimento Público (IAP) e o Índice de Proteção de Vida Aquática (IVA) não foram utilizados no trabalho, preferindo-se o IQA como indicador de qualidade das águas, em razão deste indicador existir desde o início do programa, enquanto que o IAP e o IVA foram implementados nos relatórios da CETESB somente no ano de 2002.

Os indicadores sociais, econômicos e institucionais utilizados na pesquisa foram definidos a partir da verificação de indicadores de desenvolvimento sustentável validados e mundialmente mais utilizados nos principais sistemas de indicadores já desenvolvidos, em especial os indicadores da Comissão de Desenvolvimento Sustentável (CDS) das Nações Unidas, conforme já mencionado, por ser uma das principais experiências internacionais, e os indicadores desenvolvidos pelo IBGE, no Brasil, baseados naqueles, e pela Fundação SEADE, no Estado de São Paulo. Foi considerada, ainda, na seleção dos indicadores, a facilidade na obtenção dos dados.

Optou-se por um número pequeno de indicadores, a fim de facilitar a avaliação e compreensão dos resultados. Os indicadores sociais tiveram um número maior, face à ampla diversidade de variáveis que compõem a dimensão social de desenvolvimento sustentável (saúde, educação, saneamento básico, etc.), além de se tratar de aspecto relevante da pesquisa a avaliação da repercussão da evolução do controle da poluição ambiental na melhoria da qualidade de vida da população. Foram incluídos, também, alguns indicadores recentes de condições de vida da população.

Os indicadores sociais e de condições de vida selecionados foram os seguintes:

a) Abastecimento de água-Nível de atendimento (em \%)

b) Coleta de lixo-Nível de atendimento (em \%) 
c) Esgoto sanitário-Nível de atendimento (em \%)

d) Taxa de mortalidade infantil (por mil nascidos vivos)

e) Média de anos de estudos da população de 15 a 64 anos

f) População de 25 anos e mais com menos de 8 anos de estudo

g) IDH Municipal

h) IPRS-Índice Paulista de Responsabilidade Social

i) IPVS-Índice Paulista de Vulnerabilidade Social

Para os indicadores relacionados a saneamento básico foi adotado o entendimento da Comissão de Desenvolvimento Sustentável (CDS) das Nações Unidas, que os inclui na dimensão social, por estarem relacionados às condições de saúde e de vida da população, diferentemente do IBGE, que os inclui na dimensão ambiental, uma vez que também representam degradação da qualidade do meio ambiente.

Como indicador econômico foi utilizado somente o PIB per capita, considerado suficiente para indicar a riqueza do município. Como indicadores institucionais relacionados à preocupação do município com a gestão ambiental, foram utilizados o percentual de despesas com gestão ambiental no total do orçamento do município, existência de Conselho Municipal de Meio Ambiente em atividade e existência de leis municipais específicas para proteção ou controle ambiental. Foi utilizado, ainda, o número de Ações Civis Públicas propostas e Termos de Ajustamento de Conduta formalizados pelo Ministério Público de São Paulo, a fim de possibilitar a avaliação da existência de instrumentos processuais adequados às ações relativas às causas ambientais, bem como do papel desempenhado por esse ator na evolução do controle da poluição no município.

O levantamento e coleta dos dados dos indicadores sociais, econômicos e institucionais foram desenvolvidos com base em material já elaborado, partindo, portanto, de dados secundários, oriundos em sua maioria de dois trabalhos realizados pela Fundação SEADE (Fundação Sistema Estadual de Análise de Dados), intitulados "Informações dos Municípios Paulistas-IMP" e "Perfil Municipal", disponíveis na página eletrônica da fundação. O primeiro trata-se de um sistema de informações sobre os municípios paulistas, que contém séries históricas de variáveis, reunidas em 25 temas, elaborado a partir dos dados disponíveis na própria fundação, 
bem como em diversos outros órgãos, tais como IBGE, CETESB, SABESP (Companhia de Saneamento Básico do Estado de São Paulo), etc. O segundo reúne dados sobre os aspectos administrativos, caracterização do território, demografia, condições de vida, finanças públicas, educação, saúde, estabelecimentos e trabalhadores por setor de atividade, além de um histórico do município, capazes de evidenciar, em uma rápida leitura, as principais características de cada um dos 645 municípios paulistas (FUNDAÇÃO SEADE, 2007c). Foram utilizados, ainda, dados obtidos em relatórios da CETESB, bem como alguns dados primários obtidos junto à Prefeitura Municipal de Cubatão e Ministério Público de Cubatão.

Não foi possível efetuar o levantamento das emissões de poluentes do ar e águas, por empresa, uma vez que, quanto aos poluentes atmosféricos, somente a partir do ano de 1997 os relatórios de qualidade do ar da CETESB passaram a trazer os dados de emissões individualizados por empresa. Conforme esclarecimentos obtidos junto à CETESB, os inventários das emissões de poluentes do ar, por empresa, não são feitos anualmente. O inventário da carga poluidora dos cursos d'água por efluentes industriais, por empresa, por seu turno, nunca foi efetuado em Cubatão. A fiscalização é efetuada por amostragens de chaminés e coletas periódicas dos efluentes líquidos.

Por essa razão, restou impossibilitada a avaliação do desempenho individual das empresas na evolução do controle da poluição em Cubatão no período da pesquisa.

Foi encaminhado, entretanto, formulário, via e-mail, às 21 principais empresas em atividade no pólo industrial de Cubatão, visando obter informações sobre a existência de sistemas de gestão ambiental implementados, data de implementação e identificação dos sistemas, para possibilitar a avaliação da eventual influência da adoção desses sistemas na evolução individual das empresas. O formulário continha as seguintes indagações:

\section{“1. A empresa possui Sistema de Gestão Ambiental implementado?}

( ) $\operatorname{Sim}$

( ) Não 
2. Em caso positivo, identificar o(s) sistema(s) e a data de implementação:

( ) ISO 14001

Data:

( ) Programa de Atuação Responsável-ABIQUIM

( ) SGA próprio

( ) Outro:

Data:

Data:

Data:

Obteve-se retorno de 15(quinze) das empresas, representando aproximadamente $72 \%$ daquelas consultadas. Entretanto, em razão da impossibilidade de avaliação da evolução do desempenho individual das empresas no controle da poluição, conforme acima exposto, também não foi possível avaliar a eventual influência da adoção de sistemas de gestão ambiental nessa evolução. As informações obtidas foram utilizadas somente na avaliação geral da atuação do setor industrial e dos instrumentos utilizados na evolução do controle da poluição ambiental no município.

\subsection{O QUESTIONÁRIO}

$\mathrm{Na}$ última fase, foi aplicado questionário com a finalidade de aferir a visão dos setores governamental, empresarial e sociedade civil que, no município de Cubatão, atuam ou atuaram diretamente nas questões ambientais, sobre os principais fatores determinantes da evolução do controle da poluição, ao longo da implementação do programa de controle ambiental iniciado pela CETESB em 1983, assim como compreender o atual sistema de gestão ambiental do pólo industrial de Cubatão e obter eventual proposta de melhoria.

Os questionários constituem uma modalidade de obtenção de dados que, segundo SPÍNOLA (2005), “correspondem a um desenho impresso para a obtenção de informações que são obtidas pelas respostas escritas dos participantes" (p. 930).

O questionário consistiu de duas perguntas.

A primeira questão teve como objetivo verificar hipóteses de fatores que poderiam ter influenciado a evolução do controle da poluição em Cubatão. Por essa razão, trata-se de questão do tipo fechado, na qual as opções de respostas são escolhidas com critérios técnicos pelo próprio pesquisador (SPÍNOLA, 2005). Buscou-se alternativas suficientemente exaustivas, capazes de abrigar a ampla gama 
de respostas possíveis, ou seja, os principais fatores que poderiam ter determinado a evolução do controle da poluição ambiental em Cubatão, segundo as informações obtidas na bibliografia e documentos consultados na fase de levantamento bibliográfico, abrindo-se, ainda, oportunidade para a inclusão de novas alternativas pelo informante.

Nessa questão, foi solicitada, ainda, uma graduação dos fatores escolhidos pelo participante, com a escolha de apenas 05(cinco) dentre as alternativas estabelecidas, numerando-as em ordem de importância.

"1. Identifique 05(cinco) dentre os fatores abaixo indicados que, na sua visão, foram os principais determinantes da evolução do controle da poluição em Cubatão, desde o início da implantação do Programa de Controle da Poluição do município, em 1983, até os dias atuais, numerando-os em ordem de importância de

01 a 05, acrescentando até no máximo dois outros fatores.

( )Exigências de mercado local

( )Pressão da mídia

( )Promulgação da Constituição Federal de 1988

( )Atuação do Poder Executivo do Município de Cubatão

( )Autuações da CETESB (multas administrativas)

( )Pressão da comunidade científica

( )Ações Civis Públicas movidas pelo Ministério Público

( )Atuação de ONGs

( ) Edição da Lei dos Crimes Ambientais (Lei 9.605/98)

( ) Conscientização ambiental dos dirigentes das indústrias

( )Orientação e apoio técnico da CETESB

( )Termos de ajustamento de conduta formulados com o Ministério Público

( )Avanço do conhecimento científico/tecnológico

( )Exigências de mercado internacional

( )Atuação do Poder Legislativo do Município de Cubatão

( ) Pressão da comunidade do Município de Cubatão

( ) Edição da Lei de Ação Civil Pública (Lei 7.347/85)

( )Atuação do CONSEMA

( )Decisões do Poder Judiciário 
( )Exigências da Matriz Internacional

( )

( )

Justifique a resposta:

A solicitação de justificativa da resposta teve apenas o intuito de auxiliar na sua interpretação, não sendo utilizada na tabulação dos dados.

A segunda questão, por não visar a confirmação ou não de qualquer hipótese, mas a obtenção do pensamento de uma coletividade, foi do tipo aberto. Isso porque a questão aberta, que exige resposta escrita do informante, além de dar liberdade a este, favorecendo a racionalização e a profundidade da resposta (SPÍNOLA, 2005), tem maiores chances de fazer com que o pensamento dos indivíduos se expresse como um discurso (LEFÉVRE e LEFÉVRE, 2005). A $2^{\text {a }}$ questão consistiu da seguinte:

“2. Visando subsidiar a compreensão do atual sistema de gestão ambiental do pólo industrial de Cubatão, identificar, no que se relaciona ao setor governamental, empresarial e sociedade civil, no seu entendimento:

-Pontos fracos da gestão atual:

Pontos fortes da gestão atual:

Ameaças:

Oportunidades:

O questionário foi encaminhado aos membros das principais empresas em atividade no pólo industrial de Cubatão, a membros e/ou representantes atuais do órgão ambiental (CETESB), dos Poderes Executivo e Legislativo Municipal de Cubatão e de organizações da sociedade civil, a pesquisadores que desenvolvem ou já desenvolveram trabalhos sobre questões ambientais e de saúde pública no município, bem como a pessoas que atuaram em Cubatão nesses órgãos ou 
instituições ao longo da implementação do programa de controle ambiental iniciado pela CETESB em 1983.

A seleção das pessoas de cada setor para o encaminhamento do questionário foi efetuada por amostragem intencional, que é aquela na qual o investigador se dirige intencionalmente a grupos de elementos dos quais deseja saber a opinião (SILVA, 2005). Para a definição das pessoas foi utilizada a bibliografia consultada, além de diversos documentos e informações, tais como relatórios da CETESB, site da Câmara Municipal de Cubatão e informações do CIESP (Centro das Indústrias do Estado de São Paulo) de Cubatão.

O principal critério utilizado na seleção dos participantes da CETESB, Poder Executivo, Poder Legislativo e sociedade civil, foi a efetiva atuação em Cubatão nesses órgãos ou instituições ao longo da implementação do programa de controle ambiental, independentemente do seu posicionamento político. Quanto aos pesquisadores buscou-se enviar o questionário àqueles que desenvolvem ou já desenvolveram trabalhos sobre questões ambientais e de saúde pública no município. No que se refere aos membros das indústrias, o envio do questionário buscou abranger tanto pessoas vinculadas diretamente à gestão ambiental da empresa (gerente, superintendente, etc. de meio ambiente), quanto funcionários de setor diverso (produção, administrativo).

O tamanho da amostra foi determinado pelos diversos setores dos quais se pretendia obter as informações, bem como pelo número de indústrias em atividade no pólo industrial de Cubatão.

Optou-se pelo envio do questionário por e-mail e correio, uma vez que a quantidade de informações solicitadas não era muito grande, além de permitir ao informante liberdade na resposta e melhor elaboração desta, em especial da $2^{\text {a }}$ questão, enriquecendo o resultado da pesquisa.

Foi realizado pré-teste do questionário, com o envio a 10(dez) indivíduos pertencentes ao grupo objeto da pesquisa, verificando-se que as respostas dadas não denotavam dificuldade no entendimento das questões, bem como possibilitavam categorização e análise.

O questionário foi enviado a um total de 69 (sessenta e nove) pessoas, sendo que $90 \%$ desse total foi enviado por e-mail, sendo remetido por correio somente para 
os entrevistados que não possuíam correio eletrônico. Os endereços foram obtidos via contato telefônico prévio ou por informações obtidas na CETESB e CIESP.

Os questionários enviados foram acompanhados do termo de consentimento, bem como de explicação geral da pesquisa e da finalidade da entrevista, solicitando a colaboração do participante no prazo necessário para a conclusão da pesquisa. Para aqueles que não responderam no prazo solicitado, foram reiterados os envios dos questionários, por uma vez.

Do total de 69 (sessenta e nove) questionários enviados, foram obtidas 44 respostas, representando, assim, uma adesão de aproximadamente 64\% dos participantes. Entretanto, uma das respostas não pôde ser utilizada, visto que o participante não assinou o termo de consentimento. Esse questionário foi encaminhado via correio, acompanhado do termo de consentimento e carta explicativa. Recebida a resposta, o participante não foi localizado a tempo para assinar o termo de consentimento, em razão de viagem ao Nordeste por prazo indeterminado.

\subsection{TRATAMENTO DOS DADOS}

A descrição dos resultados alcançados quanto ao desenvolvimento sustentável do município de Cubatão, pela gestão ambiental iniciada com o Programa de Controle da Poluição Ambiental, desenvolvido pela CETESB, no período de 1983 até o ano de 2005, foi feita por meio dos indicadores ambientais, econômicos, sociais e institucionais selecionados, os quais, após coletados, foram organizados em tabelas, quadros e figuras, demonstrando sua evolução nesse período.

A discussão foi efetuada considerando que, à exceção dos indicadores ambientais, não foi possível obter a evolução ano a ano dos demais indicadores no período da pesquisa, diferentemente do previsto originalmente, em razão de não existirem dados anuais disponíveis para os demais indicadores, salvo para o indicador taxa de mortalidade infantil.

A avaliação da evolução dos indicadores ambientais foi baseada na verificação da redução global obtida nas emissões dos poluentes atmosféricos 
selecionados, em tonelada/ano, na melhoria do índice de qualidade das águas, bem como no percentual de tempo em que a qualidade do ar atendeu aos padrões legais.

Efetuou-se, ainda, a avaliação da eventual repercussão da evolução do controle da poluição na riqueza do município, a partir da comparação da evolução da riqueza gerada com a evolução dos indicadores ambientais no mesmo período.

Da mesma forma, por meio da comparação da evolução dos indicadores sociais no mesmo período, demonstrada pelas tabelas elaboradas, foi avaliada a repercussão da evolução do controle da poluição na melhoria da qualidade de vida da população.

Quanto aos indicadores institucionais selecionados, foram avaliadas a importância dada pela municipalidade às questões ambientais e a existência de instrumentos processuais adequados às ações relativas às causas ambientais, bem como o papel desempenhado pelo Ministério Público do Estado de São Paulo na evolução do controle da poluição no município.

A avaliação do papel desempenhado pelos atores envolvidos na gestão ambiental do município e dos principais instrumentos utilizados foi baseada nas informações obtidas sobre o Programa de Controle da Poluição Ambiental em Cubatão e na evolução dos indicadores selecionados, em conjunto com os resultados obtidos quanto à visão daqueles sobre os principais fatores determinantes da evolução do controle da poluição no município.

A avaliação da suficiência e adequação das informações existentes para a correta avaliação da gestão ambiental do município foi efetuada com base na revisão bibliográfica sobre indicadores de desenvolvimento sustentável para o processo de tomada de decisões, considerando-se as características próprias do município, bem como as dificuldades encontradas na pesquisa para o cumprimento de todos os seus objetivos, face à ausência de informações sistematizadas sobre aspectos relevantes para a avaliação das políticas públicas necessárias para propiciar o desenvolvimento sustentável do município e região, propondo-se, em conseqüência, novos indicadores.

As duas questões que compuseram o questionário, por terem sido formuladas a partir de diferentes metodologias, também exigiram tratamento e avaliação a partir 
de metodologias distintas. O resultado geral obtido foi avaliado com base no referencial teórico adotado na pesquisa.

$\mathrm{Na}$ organização, tabulação e análise dos dados quantitativos obtidos em resposta à questão que teve como objetivo verificar os fatores predominantes na evolução do controle da poluição em Cubatão, segundo a visão dos participantes, foi utilizada a técnica de análise descritiva, por meio de tabelas de distribuição de freqüência, tabelas de contagens e percentuais, bem como gráficos de Barra, para ilustrar as análises.

$\mathrm{Na}$ avaliação dessa questão foram observadas somente 42 (quarenta e duas) respostas, do total de 44 (quarenta e quatro) obtidas, uma vez que, além de não ter sido possível utilizar a resposta de um dos participantes, conforme justificado no tópico anterior, um outro indivíduo limitou-se a responder apenas a segunda parte do questionário.

As respostas foram, ainda, subdivididas em 06 (seis) grupos, conforme o setor de atuação do informante: Poder Executivo (n1=5), Poder Legislativo (n2=4), Comunidade Científica (n3=3), Sociedade Civil (n4=3), Cetesb (n5=7) e Indústrias $(\mathrm{n} 6=20)$.

A proposta original de avaliação da visão de cada segmento ou grupo, separadamente, foi abandonada, em virtude do tamanho da amostra não ser suficientemente razoável para descrever algum fator, devido à baixa adesão à pesquisa dos indivíduos de alguns setores, como comunidade científica, sociedade civil e Poder Legislativo.

Não foi possível aplicar nenhum teste por ter muitas caselas (células) vazias, ao cruzar os fatores com os grupos, dificultando a aplicação de algum tipo de teste.

$\mathrm{Na}$ organização e tabulação dos dados qualitativos obtidos em resposta à questão que teve como objetivo compreender o atual sistema de gestão ambiental do pólo industrial de Cubatão, segundo a visão dos participantes, foi utilizada a metodologia do discurso do sujeito coletivo, que é uma técnica de "organização e tabulação de dados qualitativos de natureza verbal, obtidos de depoimentos, artigos de jornal, matérias de revistas semanais, cartas, papers, revistas especializadas, etc", que permite, por meio de procedimentos sistemáticos e padronizados, agregar depoimentos sem reduzi-los a quantidades (LEFÉVRE e LEFÉVRE, 2005, p. 15-16). 
A escolha da metodologia do discurso do sujeito coletivo, a despeito da existência de outras metodologias, se deve ao fato dessa questão ter como objetivo compreender o atual sistema de gestão ambiental do pólo industrial de Cubatão, segundo a visão dos participantes, descrevendo essa visão e não uma interpretação dessa visão a partir de referências teóricas, históricas, ideologias, representações sociais, etc, como ocorre nas metodologias qualitativas tradicionais, nas quais o discurso é decomposto, reagrupado e interpretado. Nestas, os discursos não são os dados. Estes são extraídos do conjunto de discursos e tabulados por meio de categorias, categorização essa feita pela extração de palavras, conceitos ou expressões consideradas pelo pesquisador como adequadas para representar os discursos (CALDEIRA, 1984; MINAYO, 1999). Dessa forma, os discursos empíricos deixam de existir, passando a valer o nome ou o título da categoria, que substitui e simboliza aqueles, propiciando sua classificação, fato que não ocorre na metodologia do discurso do sujeito coletivo, no qual se faz a reconstrução, com pedaços de discursos individuais, de tantos discursos-síntese quantos se julgue necessários para expressar um dado pensar ou representação social sobre um fenômeno, que é o modo como os indivíduos reais, concretos, pensam. A metodologia permite, também, tratamento quantitativo dos discursos, resultando em uma pesquisa qualiquantitativa (LEFÉVRE e LEFÉVRE, 2005).

A metodologia do discurso do sujeito coletivo, conforme os autores, consiste na análise do material coletado, extraindo-se seus trechos mais relevantes, que são chamadas de expressões-chave $(\mathrm{ECH})$. O segundo passo consiste em atribuir um nome ou descrição suscinta àquilo que foi dito, ou seja, ao discurso das expressõeschave, que é o que se chama de idéia central (IC) e/ou ancoragem (AC). Para a identificação e nomeação de uma idéia central de um conjunto de depoimentos, é necessário examinar e identificar as expressões-chave e idéias centrais presentes em cada um deles, como foi feito na presente pesquisa. Na sequiência, utilizando-se as expressões-chave e as idéias centrais ou ancoragens semelhantes ou complementares, faz-se a composição de um ou vários discursos-síntese na primeira pessoa do singular, resultando na expressão do discurso de um sujeito coletivo (DSC), que viabiliza um pensamento social. Esse pensamento coletivo é um idioma obtido por abstração, a partir de um conjunto de falas individuais de sentido reputado 
semelhante ou complementar, por meio do qual se constrói a fala do social ou um discurso compartilhado.

A idéia central (IC) é um nome ou expressão lingüística que revela e descreve o sentido de cada um dos discursos analisados e de cada conjunto homogêneo de expressões-chave, ou seja, revela "o que foi dito", da maneira mais sintética, precisa e fidedigna possível, que vai dar nascimento, posteriormente ao discurso do sujeito coletivo (DSC). As expressões-chave (ECH) são pedaços, trechos ou transcrições literais do discurso que revelam o conteúdo discursivo dos segmentos em que se divide o depoimento, os quais remetem à idéia central e a corporificam. Já a ancoragem (AC) "é a manifestação lingüística explícita de uma dada teoria, ou ideologia, ou crença que o autor do discurso professa e que, na qualidade de afirmação genérica, está sendo usada pelo enunciador para enquadrar uma situação específica" (p. 17). O Discurso do Sujeito Coletivo (DSC) é, portanto, um discursosíntese, redigido na primeira pessoa do singular, composto por pedaços de discursos de sentido semelhante reunidos num só discurso.

$\mathrm{Na}$ metodologia do discurso do sujeito coletivo, os resultados são apresentados na forma de um painel de discursos de sujeitos coletivos, enunciados na primeira pessoa do singular, que reflete o modo de pensar num dado grupo, coletividade, etc. ou sobre determinado assunto. Uma vez processados os dados, o discurso do sujeito coletivo gerado permite, ainda, tratamento quantitativo.

No processamento dos dados foi utilizado o software "Qualiquantisoft", desenvolvido com o objetivo de facilitar a realização de pesquisas qualiquantitativas nas quais é utilizada a técnica do Discurso do Sujeito Coletivo, o qual tem os seguintes componentes:

Cadastros: permitem arquivar dados e bancos de dados relativos a entrevistados, pesquisas, perguntas, cidades e distritos, entre outros;

Análises: são quadros e processos que permitem a realização de todas as tarefas necessárias à construção dos Discursos do Sujeito Coletivo;

Ferramentas: permitem a exportação e a importação de dados e resultados de pesquisa;

Relatórios: organizam e permitem a impressão dos principais resultados da pesquisa (IPDSC, 2007). 
Para o processamento dos dados desta pesquisa, utilizando-se a metodologia do Discurso do Sujeito Coletivo e o software Qualiquantisoft, foi contratado o Instituto de Pesquisa do Discurso do Sujeito Coletivo Ltda (IPDSC).

$\mathrm{Na}$ avaliação dessa questão também foram observadas somente 42 (quarenta e duas) respostas, do total de 44 (quarenta e quatro) obtidas, uma vez que, além de não ter sido possível utilizar a resposta de um dos participantes, conforme já mencionado, um outro indivíduo limitou-se a responder apenas a primeira parte do questionário.

Processados os dados, foi realizada, inicialmente, uma análise descritiva dos resultados qualitativos, obtendo-se os diversos discursos da coletividade participante em relação a cada um dos tópicos em que se dividiu a pergunta: Pontos fracos da gestão atual, Pontos fortes da gestão atual, Ameaças e Oportunidades.

Foi efetuada, ainda, análise quantitativa de distribuição das idéias centrais, segundo os participantes, frente a cada um dos tópicos retro mencionados, e, ao final, uma avaliação geral do discurso do sujeito coletivo produzido, com base no referencial teórico adotado. 


\section{RESULTADOS E DISCUSSÃO}

\subsection{O MUNICÍPIO DE CUBATÃO}

Neste item são apresentadas as características gerais do município de Cubatão, o histórico da implantação do pólo industrial, bem como o contexto de degradação ambiental que levou à criação do Programa de Controle da Poluição Ambiental do município pelo governo do Estado de São Paulo, no início da década de 1980.

\subsubsection{Características Gerais}

Cubatão, que por muito tempo se constituiu em distrito do município de Santos, foi elevado à categoria de município pela Lei Estadual $n^{\circ} 233$, de 24 de dezembro de 1948, verificando-se sua instalação em 09 de abril de 1949. O município de Cubatão, com área de $142 \mathrm{~km}^{2}$, está inserido na região metropolitana da Baixada Santista, contando com uma população de 108.309 habitantes (IBGE, 2000).

A Baixada Santista, geomorfologicamente, é constituída de compartimentos bem individualizados, mas de evolução interdependente: a Serra do Mar, as planícies de piemonte (formadas pelos sedimentos resultantes das elevações que as circundam), os manguezais, as planícies de páleo-restingas e as praias costeiras. Do total do território do município de Cubatão, cerca de 58\% são constituídos de serras e morros, $24 \%$ de manguezais e $18 \%$ de planícies aluviais de piemonte e mangues aterrados. A planície constitui somente uma faixa de $11 \mathrm{~km}$ de comprimento e largura variável entre 02 e $04 \mathrm{~km}$, confinada entre a serra e os manguezais, característica que contribuiu para os problemas gerados pelo crescimento urbano e industrial do município (CETESB, 1985a).

O clima de Cubatão situa-se no limite entre tropical e subtropical, sendo caracterizado por altas temperaturas, com temperaturas médias no período de verão

superiores a $25^{\circ} \mathrm{C}$, chegando as máximas a mais de $38,5^{\circ} \mathrm{C}$. Esse fato pode ser explicado pela topografia do município, que fica quase que totalmente encerrado em uma caixa, cujas paredes são formadas, ao Norte, a Oeste e a Leste, pela Serra do 
Mar e, mesmo ao Sul, parcialmente, pela Serra do Morrão, Serra do Quilombo e pequenos montes situados na ilha de Santos e São Vicente.

Os ventos predominantes são os de sul e os de leste, embora na maior parte do tempo (mais de 30\%, chegando a 45\%) predominem as calmarias e, conseqüentemente, a falta de renovação da atmosfera local. O regime de chuvas é bastante intenso, sendo as precipitações médias anuais da ordem de 2.700 milímetros (BRANCO, 1984). A média anual da umidade relativa do ar nessa região, segundo GUTBERLET (1996), fica entre 70 e $90 \%$.

As condições climáticas de Cubatão, ou seja, alta temperatura e alta média da umidade relativa do ar, associadas ao regime dos ventos, somadas, ainda, à topografia local, são altamente desfavoráveis à dispersão atmosférica de poluentes, especialmente nos meses de inverno, nos quais a quantidade de precipitações pluviométricas, que favoreceriam a redução da poluição, diminuem consideravelmente, ocorrendo o fenômeno que se denomina de inversão térmica.

O fenômeno da inversão térmica é descrito de forma simplificada por BRANCO (1984):

Ao entardecer, principalmente nas épocas mais frias do ano, o solo sofre um resfriamento muito rápido, fazendo com que as camadas de ar inferiores fiquem mais frias que as camadas superiores. Como o ar frio que está embaixo não sobe, assim como o ar quente de cima não baixa, origina-se uma situação de completa estagnação, em que toda fumaça, ao invés de subir e se dissipar tende a permanecer junto ao solo, envolvendo as casas, as pessoas e vegetação (p. 27).

A vegetação da região é caracterizada pela presença de Floresta Atlântica nas escarpas da serra e morros, que atua como agente estabilizador do solo. A área da base das encostas das serras e morros até o limite dos manguezais é ocupada por vegetação de restinga ou floresta tropical de planície litorânea, vegetação essa que sofreu fortes impactos da ocupação antrópica, assim como os manguezais, que funcionam como fixadores de sedimentos, além de possuírem a função de filtro biológico e berçário de diversas espécies da fauna.

A região da Baixada Santista, especialmente em razão da exigüidade de áreas favoráveis à agricultura, nunca se caracterizou como área agrícola, sendo a 
bananicultura a principal atividade agrícola até a primeira metade do século XX. Em Cubatão, a partir de 1960, com o intenso processo de ocupação urbano-industrial do município, subsistiram apenas pequenas áreas, que acabaram por desaparecer. Atualmente, inclusive, a lei que dispõe sobre o uso e ocupação do solo do município divide o território deste, para fins fiscais, urbanísticos e de planejamento, somente em área urbana de preservação e área urbana (art. 3º, da Lei Complementar municipal $n^{\circ} 2.513$, de 10 de setembro de 1998).

A estreita faixa de terras enxutas e planas no município, conforme acima mencionado, somada à concorrência com a expansão do uso industrial do solo, acabou gerando um forte processo de especulação imobiliária e, consequentemente, pressões para a ocupação dos mangues, com a realização de aterros, bem como das frágeis encostas serranas e morros, áreas nas quais é comum o fenômeno da proliferação de favelas (CETESB, 1985a).

A evolução demográfica de Cubatão foi bastante acelerada a partir de 1950, após a emancipação do município e a construção da refinaria de petróleo da Petrobrás, quando teve início a primeira fase de industrialização, contribuindo enormemente para a ocupação de áreas ecologicamente frágeis. GUTBERLET (1996) afirma que entre 1950 e 1980 ocorreram movimentos migratórios de forma explosiva em Cubatão, em especial de trabalhadores oriundos do Nordeste, face à grande procura de mão de obra necessária para a construção e expansão das fábricas. Contudo, após o término das obras, o número de empregados mantidos fixos era bastante reduzido, levando esses trabalhadores desempregados à ocupação ilegal de terrenos pouco valorizados ou públicos, como margens de rodovias e ferrovias, e áreas de proteção ambiental, como escarpas e manguezais.

O município, que em 1950 contava com uma população de 11.803 habitantes, mais que dobrou dez anos depois, passando para 25.166 em 1960. Em 1970, verificase que a população havia novamente duplicado, passando para 51.009 habitantes. De 1970 a 1980, embora o aumento da população tenha sido considerável (79.844 habitantes em 1980), começou a diminuir, estabilizando-se a partir da década de 90, alcançando o número de 91.049 em 1991 e 108.309 habitantes em 2000 (IBGE, 1950, 1960, 1970, 1980, 1991 e 2000). Segundo dados da Fundação SEADE, era de 
117.289 o total da população residente no ano de 2005 (FUNDAÇÃO SEADE, 2007c).

Essas características, que configuram uma situação de alta vulnerabilidade ecológica e baixa adequabilidade a determinados usos, entretanto, não impediram um intenso crescimento urbano e industrial do município de Cubatão, cujo histórico é apresentado no item seguinte.

\subsubsection{Histórico da Implantação do Pólo Industrial de Cubatão}

Longe da pretensão de esgotar todos os elementos da implantação do parque industrial de Cubatão, cabem aqui algumas considerações sobre sua evolução histórica e os principais motivos que determinaram sua característica de pólo industrial sídero-petroquímico.

Cubatão, durante séculos, caracterizou-se como porto de pé de serra, onde se realizava o transbordo de pessoas e mercadorias entre o porto de Santos e o Planalto, função portuária que foi decaindo com a construção do "Aterrado" ou "Entulhado" sobre o manguezal, fazendo-se a ligação por terra entre Cubatão e Santos. E foi a posição estratégica de Cubatão ao pé da Serra do Mar, ponto de convergência e passagem obrigatória de diversos sistemas de circulação (ferrovias e rodovias), e próxima ao Porto de Santos, que determinou a instalação de seu complexo industrial.

Os engenhos de cana-de-açúcar e as olarias foram as primeiras atividades do tipo industrial praticadas no município de Cubatão, seguidas dos curtumes, instalados devido à abundância do tanino extraído das folhas dos mangues. Entretanto, essas atividades, que utilizavam matéria-prima local e empregavam mão de obra também local, não conseguiram sobreviver ao rápido processo de industrialização do município (PERALTA, 1979).

A primeira indústria a se instalar em Cubatão foi a Cia. Curtidora Max, no ano de 1912, tendo como dirigentes um grupo de industriais alemães. Como reflexo da $1^{\text {a }}$ Guerra Mundial, a indústria acabou paralisando suas atividades, sendo suas instalações ocupadas, em 1918, pela Costa Moniz Indústria e Comércio S/A, que manteve a atividade de curtume, passando em 1929 a dedicar-se à fiação e tecelagem de correias de lona e borracharia, à medida que os manguezais foram sendo suprimidos. A partir de 1942, a produção de mangueiras de combate ao fogo passou a ser sua principal atividade (CUBATÃO (Prefeitura Municipal), 1976). 
GOLDENSTEIN (1965), entretanto, afirma que a primeira indústria a se instalar em Cubatão foi a Costa Moniz Ind. e Com., porém, no ano de 1895.

À empresa Costa Moniz se seguiu a instalação da Cia. J.B. Duarte, em 1914, que iniciou suas atividades produzindo adubo e tanino. Com o passar dos anos, a empresa foi diversificando as atividades, contando, já em 1928, com a produção de anilinas, ácido carbônico, carbonatos, fosfatos, silicatos e bicarbonato de amônia. A partir de 1937, a empresa passou a se denominar Companhia de Anilinas e Produtos Químicos do Brasil, acabando por falir na década de 1960.

Em 1918, iniciou-se a implantação da Companhia Fabril de Cubatão, que começou a produzir em 1922, paralisando suas atividades em 1929. A arrematação da massa falida da empresa foi feita, então, pela empresa Companhia Santista de Papel, no ano de 1932, que retomou as atividades de produção de papel. Essas duas indústrias "marcaram o início das transformações econômicas e sociais do distrito de Cubatão, contribuindo para a formação do espírito de autonomia que eclode em 1949”, muito antes do surgimento do período de industrialização do município (PERALTA, 1979, p. 97)

A instalação da primeira usina hidrelétrica pela empresa Light-Serviços de Eletricidade S/A, em 1926, representou uma fase de efervescência para o município, mas foi a partir da construção da Usina Subterrânea de Cubatão, nos anos de 1952 a 1955, que se iniciou a transformação do município em grande pólo industrial, diante da farta disponibilidade de energia elétrica (GOLDENSTEIN, 1965). A esse fato deve ser somada a construção da Rodovia Anchieta, entre São Paulo e Santos, finalizada em 1947, que garantiu o fluxo de transporte entre o local de produção e a metrópole (São Paulo) (GUTBERLET, 1996).

A inauguração da Refinaria "Presidente Artur Bernardes" pela Petrobrás, em 1955, viria determinar a formação do atual complexo industrial petroquímico, uma vez que a ela se seguiram a instalação de outras indústrias, especialmente indústrias voltadas para o aproveitamento dos derivados de petróleo (CUBATÃO (Prefeitura Municipal), 1976).

Segundo FERREIRA (1993), duas ordens de fatores contribuíram para a implantação da refinaria da Petrobrás em Cubatão e, em consequência, da indústria petroquímica, apesar das condições locais desfavoráveis. A primeira delas diz 
respeito exclusivamente à decisão política, respondendo diretrizes traçadas no nível federal. Nesse período vivia-se no país a 'Doutrina de Segurança Nacional e Desenvolvimento', cujo principal objetivo, tendo em vista a promoção do 'milagre econômico brasileiro', era reforçar o potencial produtivo nacional, para aumentar o poder de barganha na arena geopolítica global, legitimando um crescimento econômico acelerado e predatório, sem qualquer preocupação com a melhoria da qualidade de vida da população como um todo. "A única perspectiva levada em conta na avaliação de projetos era econômico-financeira", uma vez que inexistiam pressões políticas sobre restrições ambientais ou restrições internacionais a financiamentos (p. 41).

O salto industrializante proposto, justificado por via da presença do Estado, como de 'interesse nacional', e legitimado no nível da opinião pública como 'o interesse geral', fez com que fosse descartada qualquer discussão setorizada sobre os problemas de ordem social ou ambiental, havendo como que "um acordo pela construção da identidade nacional calcada no desenvolvimentismo" (p. 43), contexto no qual as questões de infra-estrutura de transportes e energia, o equacionamento dos problemas das indústrias siderúrgica e petrolífera e a instalação de novos setores industriais adquiriram foros de problemas nacionais, prioritários e intangíveis, tanto que o complexo industrial de Cubatão contou sempre com a capa protetora dos Órgãos de Segurança Nacional.

A segunda ordem de fatores, ainda conforme Ferreira, responde à lógica econômico-financeira e se refere à proximidade do maior mercado consumidor (o parque industrial de São Paulo), disponibilidade de energia, facilidade de comunicações, pré-existência de canais de circulação de matérias-primas e produtos (porto, oleoduto, rodovia e ferrovia) e abundância de água.

Assim, foram instaladas, na seqüência, as indústrias Alba S/A-Indústrias Químicas (1956), Companhia Brasileira de Estireno (1957), Companhia Petroquímica Brasileira-COPEBRÁS (1958), Fibrastec-Comércio, Indústria e Importação Ltda (1958), Petrobrás Química S/A-Fábrica de Fertilizantes (1958) e Union Carbide do Brasil S/A Indústria e Comércio (1958), caracterizando-se como indústrias de base, dedicadas à produção de matérias-primas. 
Em 1963, a instalação da Companhia Siderúrgica Paulista (COSIPA) veio incrementar a base industrial em formação, completando a característica do pólo industrial de Cubatão como pólo sídero-petroquímico. A ela se seguiram a instalação da Carbocloro S/A-Indústrias Químicas (1966), Clorogil S/A-Indústrias Químicas (1966), Fábrica de Cimento Santa Rita S/A (1968), Liquid Carbonic Indústrias S/A (1970), Ultrafértil S/A-Indústria e Comércio de Fertilizantes (1970), Engeclor Indústria Química S/A (1971), Fertilizantes União S/A (1972), Engebasa-Mecânica e Engenharia da Baixada Santista Ltda (1973), Petrocoque S/A-Indústria e Comércio (1975) e IAP S/A-Indústrias Agro-Pecuárias (1975) (CUBATÃO (Prefeitura Municipal), 1976).

A mão-de-obra utilizada na construção das fábricas era desqualificada e formada especialmente por trabalhadores oriundos da região Nordeste, parte dos quais acabaram por se fixar no município. Entretanto, altamente mecanizadas e automatizadas, as fábricas, desde o início, empregavam na sua operação um número de operários relativamente baixo quando comparado ao valor da produção, a maioria deles operários qualificados (GOLDENSTEIN, 1965). Assim, conforme afirma BRANCO (1984), concluídas as obras, restava sempre um enorme saldo de desempregados, de problemas habitacionais, alimentares e ambientais para a cidade.

Outra característica, segundo GOLDENSTEIN (1965), foi a total ausência de planejamento da instalação das indústrias, que foi "espontânea" e "desordenada", em função das necessidades próprias daquelas, localizando-se perto ou longe do núcleo urbano, ignorando-se a direção dominante dos ventos, fato que, aliado à ausência de planejamento da expansão do próprio núcleo urbano já existente, acarretou diversos problemas à população e ao meio ambiente, face ao alto potencial poluidor dessas indústrias.

Aspecto relevante destacado pela autora é que a formação do processo de industrialização do município não foi determinada pelo núcleo urbano preexistente, mas veio totalmente de fora, sendo realizada por grandes empreendimentos externos, que estabeleceram relações sociais com todos os municípios da Baixada Santista, fato que dificultou a integração com o núcleo urbano já existente, sendo um dos fatores responsáveis pelo aglomerado urbano não ter acompanhado o desenvolvimento industrial. PERALTA (1979) afirma que o desenvolvimento 
industrial de Cubatão "manteve-se paralelo à cidade e não em simbiose com ela" (p. $135)$.

Conforme facilmente se observa, a implantação do pólo industrial de Cubatão se deu em ritmo bastante acentuado, estando, desde o início dos anos 80, praticamente esgotada a disponibilidade de áreas, bem como a capacidade de assimilação do meio ambiente (CETESB, 1985a).

Atualmente, o pólo industrial de Cubatão abriga 21 (vinte e uma) indústrias de grande porte, sendo dez indústrias químicas/petroquímicas, sete indústrias de fertilizantes, uma siderúrgica, uma fábrica de papel, uma de cimento e uma de gesso, além de outras de pequeno e médio porte (CETESB, 2005).

\subsubsection{O Contexto de Degradação Ambiental do Município no Início da} Década de 1980

O processo de industrialização de Cubatão, ocorrido em ritmo acelerado, sem qualquer planejamento e ignorando os aspectos ambientais e sociais, conforme apresentado no item anterior, originou uma série de impactos ao município e região, dentre os quais podem ser destacados os seguintes: perda de habitat e decréscimo da produtividade biológica, poluição das águas e do ar, danos à vegetação da Serra do Mar, contaminação do solo e águas subterrâneas, problemas de saúde ocupacional e de saúde pública, ocupação de áreas ambientalmente sensíveis e riscos de acidentes no complexo industrial e nas rotas de transporte de sustâncias perigosas (SÁNCHEZ, 2000).

Neste item, serão abordados, de maneira resumida, os principais aspectos do contexto de degradação ambiental do município, que levou à criação do Programa de Controle da Poluição Ambiental em Cubatão, no ano de 1983, tendo como base informações constantes de estudos e relatórios elaborados à época, especialmente pela CETESB.

No aspecto da poluição do ar, no final da década de 1970 e início da década de 1980, as concentrações de material particulado vinham sistematicamente ultrapassando os padrões diários de qualidade do ar na Vila Parisi, onde se concentra

o complexo industrial do município, com picos de concentração de até $1914 \mathrm{ug} / \mathrm{m}^{3}$, 
constatando-se altas concentrações de fluoretos sólidos nesse material, atingindo picos de até 78,408 ug/m $\mathrm{m}^{3}$. Ocorriam, ainda, altas concentrações de $\mathrm{SO}_{2}$ em CubatãoCentro, dependendo da direção dos ventos, onde também era comum a ultrapassagem dos padrões para monóxido de carbono (CO) e ozona $\left(\mathrm{O}_{3}\right)$ (COMISSÃO INTERMINISTERIAL DE CUBATÃO, 1982).

Segundo relatório da CETESB, elaborado em 1981, o complexo industrial de Cubatão emitia cerca de 30.000 t/mês de poluentes atmosféricos, distribuídos percentualmente, por atividade industrial, da seguinte forma:

Tabela 3 - Emissão de poluentes - distribuição percentual por atividade industrial.

\begin{tabular}{lccccc}
\hline \multirow{2}{*}{ Atividade Industrial } & \multirow{2}{*}{$\begin{array}{c}\text { Número } \\
\text { de } \\
\text { Industrias }\end{array}$} & $\begin{array}{c}\text { Gases } \\
\text { Inorgânicos }\end{array}$ & $\begin{array}{c}\text { Material } \\
\text { Particulado }\end{array}$ & Orgânicos & Ácidos \\
\hline Química & & & & & \\
- Fertilizantes & 7 & 50,8 & 81,3 & 31,3 & 93,6 \\
- Petróleo e Derivados & 5 & 17,6 & 1,4 & 52,6 & - \\
- Outros & 5 & 0,8 & 0,2 & 0,8 & 4,0 \\
\hline Metalúrgica & 1 & 9,3 & 16,6 & 15,6 & 2,1 \\
\hline Papel e Papelão & 1 & 0,6 & 0,0 & 0,0 & - \\
\hline Minerais não metálicos & 3 & 0,9 & 0,5 & 0,0 & - \\
\hline Borracha & 1 & 0,0 & 0,0 & 0,0 & - \\
\hline
\end{tabular}

Fonte: CETESB, 1984.

Somente a emissão de material particulado no município, conforme a CETESB, era de 5.400 toneladas por mês no ano de 1982, sendo que desse total, 4.100 toneladas por mês correspondiam a emissões de fontes sem nenhum tipo de controle. Em razão das inúmeras ultrapassagens dos padrões de qualidade do ar, em especial para os poluentes material particulado e ozona, a região de Cubatão estava saturada em termos de qualidade do ar, constituindo-se em área crítica de controle, exigindo a adoção de ações enérgicas e emergenciais. O órgão ambiental, por meio 
de análises das concentrações de poluentes obtidas das estações automáticas de medição instaladas no município, observou, ainda, que durante curtos períodos de tempo, ocasião em que a direção predominante dos ventos era das indústrias para as estações, obtinham-se concentrações elevadíssimas de determinados poluentes. Como as estações estavam instaladas em centros habitacionais de Cubatão, nesses períodos a população estava respirando um ar altamente contaminado (CETESB, 1983b).

Fato que concorria para a situação crítica de poluição do ar verificada no início da década de 1980 em Cubatão é a dificuldade de dispersão dos poluentes característica do local, diante da localização das indústrias, dispostas ao longo da estreita planície aluvial do município, encravada entre o paredão da Serra do Mar ao norte, nordeste e oeste e o litoral ao sul e sudeste, avançando eventualmente pela zona de mangues. Conforme apurado, o local é totalmente inadequado para esse fim, uma vez que as correntes aéreas prevalecentes na área são de sul e sudoeste, fazendo com que as plumas de poluentes não encontrem condições adequadas para sua dispersão, sendo conduzidas para junto da escarpa da serra, onde permanecem aprisionadas (CETESB 1983a).

No que diz respeito à cobertura florestal, estudos realizados nesse período apuraram que $80 \%$ das emissões de poluentes atmosféricos liberados na região de Cubatão ocorriam na porção final do vale do Rio Mogi, incidindo, por ação das correntes aéreas, diretamente sobre a cobertura florestal das escarpas da Serra do Mogi e vertente noroeste da Serra do Morrão, locais nos quais a vegetação apresentava sua máxima degradação. Também começava a apresentar degradação acentuada a vegetação das escarpas serranas e dos morros da baixada situados na altura da sede do município de Cubatão e do antigo Caminho do Mar, atrás da Refinaria Presidente Bernardes, em razão da ação de poluentes conduzidos pelos ventos de encontro às encostas da Serra do Mar.

Do total de poluentes emitidos pelo complexo industrial de Cubatão, apurouse que 53\% eram gases inorgânicos, apresentando alguns de seus constituintes elevada fitotoxicidade aguda e crônica (óxidos de enxofre e de nitrogênio, amônia e cloro). Os óxidos de nitrogênio, ainda, atuavam em reações fotoquímicas na atmosfera, dando origem a ozona, peroxiacetil e nitratos, compostos também tóxicos 
à vegetação. $\mathrm{O}$ material particulado, por reduzir a capacidade fotossintetizante das plantas, também interferia no desenvolvimento destas, sendo a situação agravada pelas emissões ácidas face à natureza extremamente agressiva de seus componentes, como os ácidos sulfúrico, clorídrico, fluorídrico e gás sulfídrico, os quais causam danos agudos à vegetação exposta, caracterizados por intensa queima foliar. Da mesma forma, as substâncias orgânicas emitidas, além de afetarem a vegetação, podiam, através de reações fotoquímicas com dióxido de nitrogênio, formar complexos oxidantes (PAN) de significativa toxicidade.

Foram verificadas alterações significativas da vegetação primitiva, tanto na composição florística e estratificação quanto no aspecto dos indivíduos vegetais, sendo que as árvores de maior porte remanescentes apresentavam-se despojadas de folhas e até desgalhadas, completamente secas. Os vegetais menores mostravam estrutura foliar rala e danificada, com folhas queimadas e alteradas em termos de sua coloração natural (COMISSÃO INTERMINISTERIAL, 1982).

Tabela 4 - Situação da cobertura florestal das áreas montanhosas em Cubatão nos anos 1962, 1977 e 1980.

\begin{tabular}{|c|c|c|c|c|c|c|}
\hline & \multicolumn{2}{|c|}{1962} & \multicolumn{2}{|c|}{1977} & \multicolumn{2}{|c|}{1980} \\
\hline & $\begin{array}{r}\text { Área } \\
\mathrm{km}^{2}\end{array}$ & $\begin{array}{r}\% \text { área } \\
\text { total do } \\
\text { município }\end{array}$ & $\begin{array}{l}\text { Área } \\
\mathrm{km}^{2}\end{array}$ & $\begin{array}{r}\% \text { área } \\
\text { total do } \\
\text { município }\end{array}$ & $\begin{array}{r}\text { Área } \\
\mathrm{km}^{2}\end{array}$ & $\begin{array}{r}\% \text { área } \\
\text { total do } \\
\text { município }\end{array}$ \\
\hline $\begin{array}{l}\text { Mata tropical densa } \\
\text { não degradada }\end{array}$ & 61,7 & 47,5 & 16,1 & 12,4 & 13,4 & 10,3 \\
\hline $\begin{array}{l}\text { Mata com degradação } \\
\text { fraca }\end{array}$ & 1,3 & 1,0 & 28,7 & 22,1 & 19,5 & 15,0 \\
\hline $\begin{array}{l}\text { Mata com degradação } \\
\text { média }\end{array}$ & 0,7 & 0,5 & 10,7 & 8,2 & 14,4 & 11,1 \\
\hline $\begin{array}{l}\text { Mata com degradação } \\
\text { forte }\end{array}$ & 0,0 & 0,0 & 5,7 & 4,4 & 11,2 & 8,6 \\
\hline $\begin{array}{l}\text { Área ocupada por } \\
\text { vegetação florestal } \\
\text { intacta e alterada }\end{array}$ & 63,7 & 49,0 & 61,2 & 47,1 & 58,5 & 45,0 \\
\hline
\end{tabular}

Fonte: Comissão Interministerial, 1982.

Estudo realizado pela CETESB também confirmou a ação degradatória dos poluentes emitidos pelo complexo industrial de Cubatão sobre a vegetação da Serra 
do Mar, seja pela ação isolada das substâncias fitotóxicas liberadas, seja pelo sinergismo entre as várias substâncias presentes na atmosfera do local. Além dos efeitos diretos sobre a vegetação, os poluentes também propiciavam condições favoráveis à infestação de patógenos, em virtude de diminuírem a resistência das plantas (CETESB, 1984).

Para BRANCO (1984), a morte de árvores, principalmente aquelas de grande porte, foi um dos impactos mais notórios em conseqüência da poluição do ar, nas encostas da Serra do Mar, especialmente naquelas mais voltadas para a área industrial, estendendo-se por alguns vales até as cotas mais elevadas da serra. A ação de poeiras ou de gases tóxicos, como o $\mathrm{NO}_{2}$ e o $\mathrm{SO}_{2}$, emitidos por indústrias de Cubatão, bem como a precipitação de chuvas químicas, normalmente denominadas de "chuvas ácidas", "formadas pela dissolução, nas gotas de chuva, de inúmeros compostos químicos existentes na atmosfera” (p. 79), provocava alteração visível da paisagem, com a substituição de florestas frondosas por uma vegetação rasteira, constituída sobretudo de samambaias, pequenas palmeiras e capins diversos, em meio à qual se destacavam os denominados "paliteiros", ou seja, os troncos e a galharia seca e despida de folhas e de liquens das árvores mortas pela poluição. Segundo o autor, muito antes da morte das árvores, já havia se observado nas encostas da Serra do Mar, especialmente nas superfícies dos troncos e rochas que fazem face direta aos ventos vindos do pólo industrial, o desaparecimento dos liquens, internacionalmente conhecidos como indicadores seguros das alterações da composição do ar devidas à poluição. A morte das árvores leva, ainda, ao desaparecimento da fauna, pela supressão de fontes de alimento e de abrigo seguro, além da ação direta da poluição sobre animais mais sensíveis, como alguns pássaros.

Outro grave efeito da poluição observado no município, ainda segundo Branco, foi a aceleração do rastejo da cobertura do solo que envolve a matriz rochosa dos morros, em consequiência da morte da vegetação, pela falta de fixação das raízes das plantas, ocasionando, especialmente em épocas de grandes chuvas, diversos escorregamentos dos morros, arrastando milhares de toneladas de barro misturado a rochas fragmentadas e troncos de árvores.

Os estudos realizados concluíram que, embora a destruição da cobertura vegetal das áreas montanhosas do município de Cubatão não pudesse ser atribuída 
exclusivamente à poluição do ar, esta era a maior causadora de devastação da mata, sobretudo no vale do Rio Mogi, atribuindo-se à emissão de poluentes atmosféricos a degradação de pelo menos $45 \mathrm{~km}^{2}$ de mata entre os anos de 1962 e 1980, enquanto que as demais atividades (obras de engenharia, construção de estradas, exploração de pedreiras e ocupação humana nas encostas dos morros) eram responsáveis apenas pela degradação de cerca de $5 \mathrm{~km}^{2}$ de mata no mesmo período (COMISSÃO INTERMINISTERIAL, 1982).

Quanto à poluição das águas, verificava-se no ano de 1981, considerando os resultados oriundos de amostras coletadas mensalmente pela CETESB em quatro pontos de amostragem no Rio Cubatão, que, no primeiro ponto, situado a montante da cidade de Cubatão e do local de descarga dos canais de fuga da Represa Billings, onde o rio era considerado de classe 2, a qualidade das águas era boa, assim como nos pontos correspondentes aos Canais de Fuga 1 e 2 da mencionada represa, embora em todos esses pontos tenha havido uma ligeira queda na qualidade nesse ano. No ponto CB 2400, a jusante da confluência com o Rio Perequê e da cidade de Cubatão, entretanto, a qualidade era apenas aceitável e vinha apresentando uma queda gradativa na média móvel a partir de 1979. Podia-se concluir, assim, que o Rio Cubatão apresentava uma queda na qualidade de suas águas de montante para jusante, bem como uma piora no ano de 1981, especialmente para os parâmetros coliformes fecais e totais, nitrogênio amoniacal e Demanda Bioquímica de Oxigênio, indicando poluição por esgotos sanitários e industriais existentes ao longo do curso final do rio, logo a montante do último ponto de amostragem. Nos pontos situados a jusante das indústrias, tanto no Rio Cubatão, como nos Rios Perequê e Mogi, os resultados das amostras coletadas pelo órgão ambiental demonstravam que as águas dos rios vinham apresentando uma deterioração acentuada no que se refere a índice de toxidez, com ultrapassagens, em quase todos os meses, dos padrões de fenol, nitrogênio amoniacal, coliformes fecais e totais e nitratos, além de ultrapassarem os níveis de DBO e apresentarem pH relativamente baixos, em alguns meses.

Tabela 5 - Dados de qualidade de água referentes à bacia do rio Cubatão (1981).

$$
\text { Local }
$$




\begin{tabular}{|c|c|c|}
\hline $\begin{array}{c}\text { de } \\
\text { amostragem }\end{array}$ & $\begin{array}{l}\text { Parâmetros } \\
\text { Observados }\end{array}$ & $\begin{array}{c}\text { Amostras } \\
\text { conformes / total amostras }\end{array}$ \\
\hline \multirow{3}{*}{ COSP51CB2200 } & Coli. Fecais & $5 / 12$ \\
\hline & Coli. Totais & $5 / 12$ \\
\hline & Fenol & $1 / 12$ \\
\hline \multirow{6}{*}{ COSP51CF4010 } & OD & $1 / 12$ \\
\hline & DBO & $10 / 12$ \\
\hline & Coli. Fecais & $1 / 12$ \\
\hline & Coli. Totais & $1 / 12$ \\
\hline & $\mathrm{N}$-amoniacal & $12 / 12$ \\
\hline & Fenol & $3 / 12$ \\
\hline \multirow{3}{*}{ COSP51CF4020 } & $\mathrm{DBO}$ & $9 / 12$ \\
\hline & N-amoniacal & $12 / 12$ \\
\hline & Fenol & $4 / 12$ \\
\hline \multirow{5}{*}{ COSP51CB2400 } & DBO & $3 / 11$ \\
\hline & N-amoniacal & $11 / 11$ \\
\hline & Coli. Fecais & $9 / 11$ \\
\hline & Coli. Totais & $10 / 11$ \\
\hline & Fenol & $10 / 11$ \\
\hline \multirow{6}{*}{ COSP51MO2200 } & $\mathrm{pH}$ & $11 / 12$ \\
\hline & $\mathrm{N}$-amoniacal & $12 / 12$ \\
\hline & $\mathrm{N}$-nitrato & $6 / 12$ \\
\hline & Coli. Fecais & $7 / 12$ \\
\hline & Coli. Totais & $6 / 12$ \\
\hline & Fenol & $2 / 12$ \\
\hline
\end{tabular}

Fonte: COMISSÃO INTERMINISTERIAL, 1982.

Aspecto importante no que se refere à poluição das águas, é que, embora o município já contasse com o serviço de água e esgoto operado e administrado pela Companhia de Saneamento Básico do Estado de São Paulo (SABESP), não dispunha de atendimento na coleta, tratamento e destino final de esgotos sanitários, prevalecendo o sistema unifamiliar, motivo pelo qual as condições sanitárias eram precárias.

O abastecimento de água do município também apresentava problemas, em especial a localização de um dos principais pontos de captação a jusante do lixão de Itutinga, situado em local próximo ao Rio Cubatão, onde eram dispostos os resíduos sólidos domiciliares do município, bem como resíduos industriais.

No que se refere à poluição do solo, estudo realizado no ano de 1978, pela CETESB e pelo Departamento de Águas e Energia Elétrica do Estado de São Paulo (DAEE) apurou que o complexo industrial de Cubatão produzia anualmente cerca de 
1,5 milhões de toneladas de resíduos sólidos, dos quais 67\% (1 milhão) constituíam resíduos descartáveis, verificando-se que a sua totalidade era disposta inadequadamente (arts. 51 a 56 do Decr. Estadual n ${ }^{\circ}$ 8.468/76), inclusive os resíduos industriais perigosos, revelando uma total despreocupação e falta de conscientização das indústrias sobre os riscos à saúde pública e degradação do meio ambiente. A principal forma de disposição final era a disposição a céu aberto $(61,9 \%)$, em terrenos das indústrias ou de terceiros, no lixão de Cubatão ou nos mangues, seguida do lançamento em lagoas e cursos d'água $(38,1 \%)$ (CETESB e DAEE, 1978).

O mesmo ocorria com os resíduos sólidos domésticos do município, bem como com os resíduos hospitalares, que eram dispostos de maneira inadequada em um "lixão" situado em terreno do bairro de Itutinga, a céu aberto, a poucos metros do Rio Cubatão e a montante do local de captação de água da SABESP, gerando graves riscos à saúde pública.

Nesse período foi efetuado, ainda, estudo quanto às fontes móveis de poluição do ar, observando-se que o trânsito urbano de Cubatão era quase nulo, enquanto o tráfego rodoviário era bastante intenso, uma vez que as principais vias de ligação do Planalto Paulistano à Baixada Santista, ao Litoral Norte e ao Litoral Sul atravessam o município: Rodovia Anchieta (SP-150); Rodovia dos Imigrantes (SP-160); Rodovia Padre Manoel da Nóbrega (SP-55) e Caminho do Mar (SP-148).

Foram estimados na época os valores de emissão diária dos poluentes $\mathrm{CO}$ (monóxido de carbono), $\mathrm{HC}$ (hidrocarbonetos), $\mathrm{NO}_{\mathrm{X}}$ (óxidos de nitrogênio) e material particulado, em $\mathrm{Kg} / \mathrm{dia}$, devido ao tráfego rodoviário nas Rodovias Anchieta, Imigrantes e Padre Manoel da Nóbrega (Piaçaguera e Praia Grande), para as condições de vento predominantes sul e sudoeste, chegando-se aos seguintes resultados:

Tabela 6 - Emissões diárias de poluentes devido ao tráfego rodoviário para as condições de ventos predominantes sul e sudoeste.

\begin{tabular}{llrrr}
\hline Poluentes & \multicolumn{2}{l}{$\begin{array}{l}\text { Emissões diárias sob condição } \\
\text { de ventos predominantes sul } \\
(\mathrm{kg} / \mathrm{dia})\end{array}$} & $\begin{array}{l}\text { Emissões diárias sob condição } \\
\text { sudoeste }(\mathrm{kg} / \mathrm{dia})\end{array}$ \\
\hline $\mathrm{CO}$ & $3.361,24$ & $2.776,21$ \\
\hline $\mathrm{HC}$ & 306,53 & 254,69 \\
\hline
\end{tabular}




\begin{tabular}{lrr}
\hline $\mathrm{NO}_{\mathrm{X}}$ & 296,89 & 258,50 \\
\hline Material particulado & 22,96 & 19,77 \\
\hline
\end{tabular}

Fonte: COMISSÃO INTERMINISTERIAL, 1982.

Comparando-se, entretanto, com as cargas poluidoras emitidas pelo complexo industrial, concluiu-se que a contribuição das emissões veiculares era muito pequena (CI, 1982).

Tabela 7 - Estimativa de emissão de poluentes atmosféricos no município de Cubatão em toneladas/mês

\begin{tabular}{lccccc}
\hline & $\begin{array}{c}\text { Material } \\
\text { Particulado }\end{array}$ & $\mathrm{SO}_{2}$ & $\mathrm{CO}$ & $\mathrm{NO}_{\mathrm{X}}$ & $\mathrm{HC}$ \\
\hline $\begin{array}{l}\text { Prontes } \\
\text { Industriais }\end{array}$ & 5.255 & 1.284 & 9.979 & 1.389 & 256 \\
\hline $\begin{array}{l}\text { Queima de } \\
\begin{array}{l}\text { Combustíveis em fontes } \\
\text { Estacionárias* }\end{array}\end{array}$ & 143 & 1.196 & 40 & 697 & 24 \\
\hline $\begin{array}{l}\text { Queima de combustíveis } \\
\text { em fontes móveis } \\
\text { (ventos SW) }\end{array}$ & 0,6 & - & 83 & 7,8 & 7,6 \\
\hline $\begin{array}{l}\text { *valor estimado para junho de 1982 } \\
\text { Fonte: COMISSÃO INTERMINISTERIAL, 1982. }\end{array}$ & & & & \\
\end{tabular}

Todo esse contexto de degradação ambiental provocado pela poluição oriunda do complexo industrial, somado ao crescimento urbano desordenado da cidade, caracterizado por loteamentos sem infra-estrutura e ocupações em áreas de risco e de preservação ambiental - especialmente por migrantes que vinham em busca de empregos no pólo industrial, que acabavam por não encontrar - com falta de saneamento básico, níveis de habitabilidade precários, segregação espacial e ausência de áreas de lazer, traziam diversos agravos à saúde pública.

GUILHERME (1988) dividiu os agravos à saúde pública em Cubatão, dentro desse contexto sócio-ambiental, em três grandes grupos: "os decorrentes da ausência de infra-estrutura de saneamento e habitação (agravos ligados à pobreza), os relacionados ao processo de produção (doenças profissionais, acidentes de trabalho) e aqueles decorrentes da poluição industrial” (p. 113-114), estes últimos não somente 
pela exposição dos habitantes do município à poluição dispersa por toda a área, como também a fatores de morbidade e mortalidade relativos a riscos eventuais decorrentes de agressões instantâneas, como, por exemplo, o incêndio em Vila Socó, ocorrido em 25/02/1984, provocado pelo vazamento de óleo de um duto da Petrobrás, que matou dezenas de pessoas. A autora destaca que estudos realizados no município entre os anos de 1978 a 1980 detectaram, além de anomalias congênitas em recém-nascidos, diversas deficiências de desenvolvimento físico e/ou mental sem causa aparente, que poderiam estar relacionados à ação dos poluentes.

Pesquisa realizada no ano de 1981, envolvendo análises de sangue de 496 indivíduos provenientes de Cubatão, dentre moradores e funcionários de indústrias, tendo como grupo controle 100 indivíduos de São José do Rio Preto-SP, cidade praticamente sem poluição industrial, constatou diversas alterações hematológicas no primeiro grupo, em contraste com os indivíduos de São José do Rio Preto, que não apresentavam tais alterações. Essas alterações evidenciavam a extensão do processo deletério causado por poluentes industriais em prejuízo do desenvolvimento morfológico e da fisiologia normal dos eritrócitos, confirmando-se um contínuo estado de lesão celular induzida por agentes oxidantes da atmosfera, indicando que estavam diretamente relacionadas com o tempo de exposição e com a proximidade dos focos emissores de poluentes. Constatou-se, ainda, intoxicação por chumbo dos moradores do município, considerando-se a toxicidade desse metal na região em razão da emissão industrial de 2.600 ton/dia de efluentes com fortes cargas de chumbo, cobre, mercúrio, zinco, entre outros, podendo causar danos ao sistema nervoso central e anemia. (NAOUM et. al, 1982, 1984).

Resultados similares foram verificados em outra pesquisa envolvendo análises do sangue de moradores de Vila Parisi, em Cubatão, e moradores da cidade de São Paulo, apurando-se que as anormalidades constatadas no primeiro grupo eram significativamente mais altas que aquelas verificadas no segundo grupo, indicando, mais uma vez, que resultavam do alto nível de poluição industrial do município (MEDEIROS et. al., 1983).

A detecção de vários casos de anomalias congênitas no município nesse período, em especial anencefalia, determinou a realização de pesquisa que, dentre outros aspectos, buscou avaliar a existência de conexão entre esses casos e a poluição 
industrial. $\mathrm{O}$ estudo concluiu que a freqüência de malformações congênitas, em nascimentos vivos, em Cubatão, não diferia daquelas obtidas em estudos semelhantes, tanto em populações sul-americanas quanto de outras regiões, sendo compatível com os níveis encontrados em locais de baixa freqüência. Verificou-se, entretanto, que as perdas gestacionais associavam-se positivamente com Cubatão como município de moradia durante a gestação, dentre outras variáveis (MONTELEONE NETO, 1986).

Embora os resultados dessa pesquisa não tenham efetuado claramente a conexão entre os casos de malformações congênitas e a poluição industrial do município, o fato teve grande repercussão na mídia e, somado à repercussão de outros estudos, conforme afirma FERREIRA (1993), acabaram criando a imagem de Cubatão como uma cidade doente, condenada. Assim, "seguindo um caminho doloroso, o mito de pujança industrial de Cubatão, paulatinamente, foi cedendo espaço ao incômodo estigma de Vale da Morte e a perspectiva ambiental - muito em função desse processo localizado - começou a ser desembaraçada da poeira acumulada durante longo tempo e a ocupar um lugar devido no debate das grandes questões pertinentes a um novo projeto nacional" (p. 41)

A excessiva poluição ambiental do município, que acarretava ausência de condições mínimas que possibilitassem a vida humana com dignidade, uma vez que efeitos adversos à saúde da população e aos ecossistemas da região eram não só esperados, como evidentes, em razão da detecção da intensa presença de substâncias químicas no meio ambiente, determinaram a criação pelo governo do Estado de São Paulo, em 1983, do Programa de Controle da Poluição Ambiental de Cubatão, o qual é apresentado nos itens seguintes, iniciando por um breve histórico do contexto político que determinou sua criação (5.2.1.), fazendo-se, na sequiência, uma descrição do programa, seus objetivos, projetos e evolução no período da pesquisa (5.2.2.).

\subsection{O PROGRAMA DE CONTROLE DA POLUIÇÃO AMBIENTAL EM CUBATÃO}




\subsubsection{Breve Histórico do Contexto Político da Criação do Programa de}

Controle da

\section{Poluição Ambiental em Cubatão}

Antes de abordar o programa criado para o controle da poluição ambiental de Cubatão propriamente dito, é preciso mencionar que sua criação, naquele momento, veio de encontro à crescente conscientização que vinha ocorrendo no mundo todo quanto à importância da proteção do meio ambiente, especialmente após a realização da Conferência das Nações Unidas sobre o Ambiente Humano, em Estocolmo, em 1972, refletida no comportamento da população do município, que cobrava soluções para o grave problema.

Na Conferência de Estocolmo, o Brasil, conforme já mencionado, apoiado por diversos países do Terceiro Mundo, defendeu três teses principais: que o desenvolvimento não deveria ser sacrificado em nome de um meio ambiente mais limpo; que os países desenvolvidos deveriam arcar com os custos de recuperação do meio ambiente, uma vez que foram os responsáveis pela maior parte da poluição; e que a soberania nacional não poderia ser sobrepujada em nome de interesses ambientais mal definidos. Contudo, a despeito dessa posição, face às pressões internas e externas, especialmente visando melhorar a imagem do país no exterior, o governo federal criou, em 1973, a Secretaria Especial de Meio Ambiente (SEMA) (LEMOS, 1995).

Nesse momento, tragédias ambientais como o caso de Love Canal, nos Estados Unidos, do Great London Smog, na Inglaterra, e do "Mal de Minamata", no Japão, conforme mencionado no item 2.4, dentre outros, evidenciando os malefícios do crescimento econômico acelerado e predatório, retratado especialmente no sacrifício de vidas humanas, que impulsionaram a criação de políticas públicas ambientais nesses países, assim como em outros, ainda nas décadas de 1950, 1960 e 1970, já tinham obtido repercussão internacional. As legislações desses países certamente influenciaram a política ambiental brasileira, que começava timidamente a emergir na década de 1970, por meio da edição de algumas normas sobre aspectos segmentados do meio ambiente (ver item 2.2.3), bastando verificar a Lei da Política Nacional do Meio Ambiente (Lei 6.938/81) que, com mais de uma década de atraso, 
adotou políticas já consolidadas nesses e em outros países para a prevenção e controle da poluição.

Esses fatos, segundo LEMOS (1995), coincidiram com o momento em que o Brasil vivia a transição do regime militar para a democracia, fato que também afetou a abordagem da proteção ambiental em diversos aspectos, destacando-se a emergência de movimentos sociais, tais como organizações de bairro, grupos ambientalistas e organizações profissionais, que passaram a desempenhar um papel político mais ativo na organização e mobilização das causas sociais, incluindo a proteção ambiental. Nesse aspecto, o suporte dado por organizações científicas, a exemplo da Sociedade Brasileira para o Progresso da Ciência (SBPC), foi fundamental.

Para FERREIRA (1993), o rompimento do silêncio que durante anos encobriu a degradação ambiental causada pelo parque industrial de Cubatão foi eminentemente político e o primeiro passo dado na direção da institucionalização do debate ocorreu em 1978, com a instituição de uma Comissão Especial de Vereadores (CEV) do município, com a finalidade de apurar os possíveis danos causados pela poluição industrial à integridade física dos moradores e trabalhadores ali assentados.

Em 1979, segundo LEMOS (1995), a publicação de um artigo no Jornal da Tarde, pelo jornalista Randau Marques, denunciando a grave situação da poluição em Cubatão, chamou a atenção de influentes políticos e cientistas para a questão, tendo como desdobramento a criação na Assembléia Legislativa do Estado de São Paulo de uma Comissão Especial de Investigação (CEI), para avaliar o problema da poluição em Cubatão e determinar ações corretivas. O relatório da comissão, finalizado dois anos depois, acusou as autoridades locais de negligência, concluindo que a implantação do pólo industrial de Cubatão se deu considerando-se somente aspectos econômicos, ignorando-se completamente os interesses da população. O relatório apontou, ainda, ineficiência e falta de efetividade da CETESB, a despeito de sua reconhecida competência técnica, recomendando a extinção do órgão e propondo a criação de uma nova Secretaria Estadual de Proteção Ambiental. Embora as conclusões da CEI não tenham resultado em ações concretas, serviram como forte instrumento de pressão, especialmente por representarem conquista de espaço pelo problema do município junto à grande imprensa paulista. 
Importante reforço, conforme FERREIRA (1993), foi a adoção pela Igreja Católica, ainda em 1979, da preservação e defesa do meio ambiente como tema da Campanha da Fraternidade, por meio da Conferência Nacional dos Bispos do Brasil (CNBB) - "Preserve o que é de todos" - como um dos grandes desafios da humanidade.

O papel da imprensa, tanto local quanto da chamada grande imprensa paulistana, afirma a autora, também foi fundamental nesse processo, especialmente pela divulgação de denúncias sobre as condições ambientais do município e suas conseqüências, não apenas para o meio ambiente natural, mas para a saúde humana, representada principalmente pelos casos de anomalias congênitas (nascimentos de crianças anencefálicas), além de doenças respiratórias, de pele, cardiovasculares e doenças profissionais. Construiu-se, assim, a imagem de uma cidade doente, condenada, produzindo-se um estigma nacional para Cubatão: o de Vale da Morte.

Em resposta a esse estigma a Secretaria Estadual de Indústria e Comércio criou, em 1981, um grupo para discutir e propor soluções para a situação de Cubatão, especialmente de Vila Parisi, denominado "Grupo de Trabalho Vale da Vida". Esse grupo era formado por um membro daquela secretaria e membros das indústrias e, dois meses depois de sua criação, apresentou um relatório com diversas recomendações, sendo a mais controversa delas a proposta de expansão do complexo industrial, com a anexação das áreas do seu entorno, após a transferência dos moradores de Vila Parisi. O relatório, que não fazia qualquer recomendação séria para o controle da poluição em Cubatão, nem reconhecia a responsabilidade das indústrias pela solução dos problemas, foi intensamente criticado por políticos locais e grupos ambientalistas, sendo continuamente denunciado na mídia (LEMOS, 1995).

Para a autora, o relatório 'Vale da Vida' fez surgir um forte movimento popular no município, liderado por sindicatos de trabalhadores e pela Igreja, que decidiu abordar o problema da poluição de um terceiro ponto de vista, defendendo ações mais fortes em face das indústrias, bem como fazendo a conexão dos problemas da poluição com outros problemas, tradicionalmente atribuídos à pobreza, tais como mortalidade infantil, falta de saneamento básico, habitações inadequadas, etc. Esse movimento culminou na criação da Associação das Vítimas da Poluição e das Más Condições de Vida de Cubatão (AVPMCVC) no final de 1981. A 
abordagem feita pela AVPMCVC dos problemas sociais e ambientais de Cubatão como resultado do padrão de desenvolvimento econômico brasileiro, afirma a autora, transformou o município em um símbolo nacional de degradação ambiental e desigualdade social, influenciando o caminho dos grupos ambientalistas na abordagem dos problemas ambientais no Brasil, bem como atraindo o apoio de outros críticos do modelo econômico brasileiro, como intelectuais e cientistas, transformando o problema em questão nacional.

Seguiu-se a esses fatos a criação pelo governo federal, por meio do Decreto Federal n 87.000, de 09 de março de 1982, de uma Comissão Interministerial (CI) destinada a propor medidas para a recuperação, controle e preservação da qualidade ambiental de Cubatão. Essa comissão, ainda conforme a autora, foi criticada pelos movimentos populares, que a acusavam de ignorar representantes legítimos da população e defender o interesse das indústrias, bem como pelas próprias indústrias. Ao final do seu trabalho, a comissão produziu diversos relatórios, porém não apontou qualquer solução concreta para a questão.

Ações concretas para solucionar os problemas da poluição em Cubatão somente viriam com a eleição de um novo governador para o Estado de São Paulo, ou seja, com a assunção do governo do Estado de São Paulo por André Franco Montoro, em 1983, o qual incluía em seu programa de governo diretrizes de proteção ambiental do Estado, questionando o estilo de desenvolvimento que vigorava no país e, em especial, no Estado de São Paulo, no qual os índices de crescimento econômico vinham sendo mais que proporcionalmente acompanhados pelos índices de poluição.

O programa de governo de Franco Montoro previa o estabelecimento de objetivos e metas de longo prazo, para que o desenvolvimento se realizasse sem prejuízo das condições ambientais, ao lado de medidas imediatas e emergenciais para atender a gravidade da situação ambiental de alguns locais, como o da cidade de Cubatão.

Uma das medidas de grande importância adotada logo no início de sua gestão, foi a criação, em abril de 1983, do Conselho Estadual do Meio Ambiente (CONSEMA), que aprovou, em maio de 1984, após debate com a sociedade civil, a Política Estadual do Meio Ambiente, posteriormente aprovada pela Assembléia Legislativa do Estado, revelando, desde logo, a intenção do governo Montoro de que 
a proteção do meio ambiente fosse um programa de governo de caráter permanente, que ultrapassaria o período de sua gestão. Assim, em março de 1986, o Estado de São Paulo tornou-se um dos primeiros do país a ter uma Secretaria Estadual de Meio Ambiente, oportunidade em que foi criado, também, o Sistema Estadual de Meio Ambiente. Cabe mencionar que foi também no governo Montoro que foram criadas pelo Ministério Público de São Paulo as Curadorias de Meio Ambiente em todas as comarcas do Estado, facilitando a defesa judicial da sociedade nas questões ambientais e aumentando a eficiência da atuação do Ministério Público na área.

Outras importantes medidas adotadas foram a criação de Áreas de Proteção Ambiental (APAs) em diversas regiões do Estado, o tombamento da Serra do Mar e a criação da estação ecológica de Juréia-Itatins, local onde se pretendia instalar usinas nucleares, dentre outras ações voltadas para a proteção do meio ambiente.

Diante do desastre ecológico de Cubatão, questão tida como de alta prioridade pelo governo do Estado, uma das primeiras medidas administrativas do governo Montoro foi determinar a realização de um completo levantamento dos fatores de poluição do município, bem como que fossem apontadas soluções para o problema, surgindo daí, ainda em 1983, um Plano de Ação para o Controle da Poluição em Cubatão (SÃO PAULO (Governo do Estado), 1987).

A CETESB foi incumbida da execução do programa, fato que, segundo FERREIRA (1993), determinou sua reestruturação institucional e fortalecimento político, aumentando a respeitabilidade e prestígio do órgão junto à coletividade e ampliando seus espaços de atuação, levando ao reconhecimento da CETESB como o espaço institucional de gestão ambiental. Conforme LEMOS (1995), importante aspecto que determinou esse reconhecimento foi a criação, no âmbito da CETESB, de um setor dedicado à educação ambiental e participação comunitária, o qual, por meio de projeto específico dentro do programa de Cubatão, conforme será comentado no item seguinte, obteve o apoio da comunidade à implementação do Programa de Controle da Poluição Ambiental no município, legitimando as ações do órgão ambiental e equilibrando o balanço de forças em favor do programa.

Assim, a gravidade do problema, sua repercussão nacional e até mesmo internacional, somada à crescente conscientização e participação da população do 
município, criaram uma densidade política suficiente para determinar a oportunidade de se exercer um controle efetivo das fontes de poluição ambiental.

\subsubsection{O Programa de Controle da Poluição Ambiental em Cubatão}

O Programa de Controle da Poluição Ambiental em Cubatão, lançado em

1983, teve como diretrizes básicas, além do controle das fontes de poluição ambiental, o desenvolvimento de estudos, pesquisas e atividades que pudessem revelar um quadro mais preciso da problemática ambiental do município, somado à conscientização das entidades e instituições da comunidade local quanto ao problema, suas dimensões e consequências, ficando a cargo da Companhia de Tecnologia de Saneamento Ambiental (CETESB), conforme já mencionado, a sua execução. O financiamento do Programa se deu, em parte, por meio de uma linha de crédito subsidiada com recursos do Banco Mundial e do governo do Estado de São Paulo, denominada Programa de Controle da Poluição (PROCOP) e, parcialmente, pelas próprias indústrias (CETESB, 1986).

Este item irá abordar de maneira sucinta os principais objetivos, projetos e atividades desenvolvidos ao longo da implantação do Programa, assim como seus resultados, segundo relatórios do órgão ambiental (CETESB), sem nenhuma pretensão de detalhar cada uma das atividades realizadas e resultados obtidos.

O Programa estabelecia como principais objetivos: a) obter o controle efetivo das principais fontes de poluição do município, de molde a garantir uma qualidade ambiental adequada à sua população; b) implantar um Plano de Ação de Emergência para episódios críticos de poluição, visando prevenir sua ocorrência e/ou minimizar suas conseqüências; c) estabelecer critérios para a alteração da legislação de zoneamento industrial e uso do solo na região; d) promover a educação ambiental da população do município, conscientizando-a de seus problemas ambientais, visando sua participação organizada no equacionamento desses problemas (CETESB, 1985b).

Previamente à elaboração do Programa foi realizada avaliação preliminar dos riscos a que a comunidade de Cubatão estava exposta, provenientes do uso e ocupação inadequados do solo, verificando-se que eram de dois tipos: 1) relativos à 
emissão de poluentes na área, gerando concentrações indesejáveis, agravadas por condições desfavoráveis de dispersão atmosférica e, no caso das águas, de capacidade de absorção dos corpos receptores; 2) relativos a acidentes passíveis de ocorrer, gerando, em curto período de tempo, altas concentrações de poluentes, além de vazamentos com possibilidades de explosões e incêndios. Foram identificados como principais fatores determinantes dos riscos relativos à emissão de poluentes: a situação topográfica e meteorológica do município, gerando condições desfavoráveis à dispersão de poluentes; a ocupação anômala do solo, com a utilização do mesmo espaço por indústrias e residências; e a obsolescência de diversos processos industriais em atividade no município. Os fatores determinantes dos riscos relativos a acidentes, por seu turno, eram ocasionados pelo transporte e manuseio de cargas perigosas; problemas geomorfológicos; interrupção no fornecimento de energia elétrica; acidentes no processo industrial; operação e manutenção inadequada de sistemas de controle de poluição; emissões residuais e lançamentos clandestinos (CETESB, 1983b).

Para a consecução dos objetivos do Programa, este foi divido em três projetos: projeto de controle da poluição ambiental; projeto de apoio técnico às ações de controle; e projeto de participação comunitária e educação ambiental.

Os objetivos básicos do projeto de controle da poluição ambiental eram, como ações corretivas, obter a redução das emissões de poluentes do ar e águas das fontes do complexo industrial de Cubatão, de modo a garantir o atendimento aos respectivos padrões legais de qualidade, assim como garantir coleta, transporte e destinação final adequados para os resíduos sólidos domésticos, hospitalares e industriais. Ainda fazia parte desse projeto, como medida preventiva, a proibição de implantação de novas fontes de poluição ou alteração de processos produtivos que pudessem acarretar acréscimos nas emissões existentes. Para atingir esses objetivos, o projeto previa a realização de diversas atividades, dentre as quais destacam-se: o levantamento da situação das fontes de poluição industrial, com a caracterização detalhada quanto ao tipo e quantidade de poluentes emitidos por cada uma das indústrias; o enquadramento legal das fontes poluidoras consideradas como prioritárias para controle; a convocação das indústrias implantadas antes da edição da Lei Estadual 997/76 para a obtenção de registro e licença de funcionamento; 
exigência de apresentação de planos de controle de poluição para cada fonte poluidora, baseados especialmente na implantação, operação e manutenção adequadas de sistemas de controle de poluentes; análise dos planos individuais de controle e, após a aprovação, acompanhamento de sua implementação; e a implantação de Plano de Ação de Emergência para atender a episódios agudos de poluição do ar, em especial a denominada Operação Inverno, realizada anualmente, no período de maio a setembro, em razão de maiores dificuldades de dispersão dos poluentes atmosféricos nesse período (CETESB, 1985b).

O projeto de apoio técnico às ações de controle, por sua vez, tinha como objetivo avaliar os efeitos da poluição ambiental na região, apontar ou identificar suas prováveis causas e definir as ações necessárias para amenizar e corrigir os danos provocados. Nesse sentido, diversos estudos foram realizados, desde estudos que pudessem estabelecer com melhor precisão a situação da problemática ambiental do município, tais como, a avaliação da qualidade do ar, levantamento e distribuição de alguns poluentes na atmosfera local (material particulado, dióxido de enxofre, dióxido de nitrogênio, fluoretos gasosos e amônia), avaliação da toxicidade das águas, sedimentos de rios e efluentes industriais, caracterização química das águas de chuva, estudo da origem e formação de oxidantes fotoquímicos e avaliação e controle de riscos ambientais, dentre outros, até estudos buscando verificar os efeitos da poluição sobre a saúde da população. O projeto de apoio compreendia, portanto, a realização dos estudos necessários ao direcionamento das ações de controle, incluindo o estabelecimento de prioridades de atendimento para situações que exigiam medidas preventivas e corretivas urgentes. Previa, ainda, a capacitação e treinamento dos agentes do órgão ambiental envolvidos na execução do programa (CETESB, 1986).

A inclusão do projeto de educação ambiental e participação comunitária no Programa de Controle da Poluição Ambiental em Cubatão surgiu do entendimento de que a participação da comunidade era fundamental para o sucesso da implementação do Programa, dando a sustentação política necessária para neutralizar o poder das indústrias e a ausência dos governos local e federal, uma vez que, nessa época, Cubatão ainda era considerada área de segurança nacional. Todavia, para que houvesse efetiva participação da comunidade era necessário que esta estivesse 
capacitada e organizada. Além disso, o desenvolvimento de ações educativas favoreceria mudanças de comportamento e atitudes frente às questões ambientais, fazendo surgir valores voltados para a proteção, preservação e melhoria das condições ambientais e de vida no município. Assim, esse projeto teve como objetivos, além de promover a educação ambiental, transmitir à população de Cubatão informações sobre o meio ambiente, bem como viabilizar, por meio de contatos e reuniões com os setores organizados da comunidade, sua participação nas discussões, encaminhamento de propostas e decisões referentes não apenas à problemática ambiental, mas também a outros setores do governo local e estadual. Os principais setores envolvidos nesse projeto foram associações de bairro, grupos religiosos e sindicatos. O projeto apurou, inicialmente, que os principais problemas que afetavam a população de Cubatão, segundo informações da própria comunidade, eram, em ordem de prioridade: saúde, moradia, desemprego, poluição, saneamento básico, autonomia política e insuficiência das formas de planejamento e educação (CETESB, 1985b).

Como parte do plano de trabalhar com a comunidade foram levantadas as reclamações da população registradas nos anos de 1982 e 1983, apurando-se as principais fontes de poluentes objeto dessas reclamações. Foi, ainda, disponibilizada uma linha de telefone gratuita para o registro dos reclamos dos moradores.

O plano de ação inicial do programa compreendia o período de julho de 1983 a junho de 1984, no qual foram realizados levantamentos dos processos e operações industriais, com o cadastro das fontes poluidoras e o inventário dos poluentes emitidos. Foram identificadas 320 fontes de poluição para controle prioritário, sendo 230 de poluição do ar, 46 de poluição do solo e 44 de poluição das águas. $\mathrm{Na}$ seqüência, foram exigidos e aprovados planos individuais para controle dessas fontes por parte das indústrias, estabelecendo-se metas para cada poluente específico, considerando-se a legislação ambiental em vigor. Esses planos individuais deveriam observar os seguintes critérios: adoção da melhor tecnologia prática disponível; atendimento aos padrões de emissão de poluentes; cronograma de implantação; e custo dos sistemas de controle. O não atendimento do cronograma resultava em penalidades, de acordo com a legislação. O prazo previsto para o término dessa primeira etapa do programa, denominada "Programa Primário de Controle", que 
compreendia o controle das 320 fontes de poluição do ar, águas e solo identificadas e autuadas, foi $31 / 12 / 1989$.

Avaliação realizada pela CETESB (1986) dos resultados obtidos pelo Programa no período de julho/83 a julho/86 revelou considerável melhoria, tanto no controle das fontes autuadas no início do programa, quanto na redução da emissão dos vários tipos de poluentes atmosféricos, conforme tabelas apresentadas a seguir, sendo obtida, ainda, redução da frequiência de episódios agudos de poluição do ar. Algumas indústrias que não cumpriram os cronogramas de implementação dos planos de controle foram autuadas. Entretanto, apesar dos avanços obtidos, o índice de qualidade do ar para material particulado, na região de Vila Parisi, continuava acima dos padrões legais. A qualidade das águas do Rio Cubatão e seus afluentes, em relação a alguns indicadores específicos, como por exemplo, os fluoretos, também permanecia insatisfatória. Além do tratamento obrigatório dos efluentes industriais exigidos nos planos de controle individuais das empresas, previa-se a solução da poluição por efluentes de origem doméstica com a implantação de rede coletora de esgotos e estação de tratamento pela SABESP, prevista para ocorrer em dezembro/86, com capacidade para atender a uma população de 70.000 habitantes.

Tabela 8 - Número de fontes controladas em Cubatão até julho/1985

\begin{tabular}{lcc}
\hline Tipo & \multicolumn{2}{c}{ Fontes Poluidoras } \\
\cline { 2 - 3 } & Autuadas & Controladas \\
\hline Ar & 230 & 130 \\
Água & 44 & 25 \\
Solo & 46 & 38 \\
\hline Total & 320 & 193 \\
\hline
\end{tabular}

Fonte: CETESB, 1986.

Tabela 9 - Reduções obtidas nos principais poluentes lançados na atmosfera de Cubatão

\begin{tabular}{lrrrr}
\hline \multirow{2}{*}{ Tipo de poluente } & \multicolumn{2}{c}{ Emissões (t/dia) } & & $\%$ \\
\cline { 2 - 3 } Material Particulado & Julho/84 & Julho/86 & & Redução \\
Dióxido de enxofre $\left(\mathrm{SO}_{2}\right)$ & 236,6 & 49,7 & & 79,0 \\
Dióxido de nitrogênio $\left(\mathrm{NO}_{2}\right)$ & 78,4 & 49,5 & & 37,0 \\
& 61,1 & 52,7 & & 14,0
\end{tabular}




\begin{tabular}{lrrr} 
Fluoretos & 2,6 & 1,1 & 58,0 \\
Amônia & 8,7 & 2,6 & 70,0 \\
Hidrocarbonetos & 90,0 & 27,5 & 69,0 \\
\hline
\end{tabular}

Fonte: CETESB, 1986.

Aspecto importante para a compreensão dos resultados do programa é que, conforme já mencionado no item 4.2., os estudos meteorológicos realizados e os índices de qualidade do ar evidenciaram a existência de duas bacias aéreas distintas no município, denominadas "Cubatão-Centro" e "Cubatão-Vila Parisi", que apresentam características peculiares, não havendo comunicação entre elas em termos de poluição atmosférica. Por esse motivo, os resultados obtidos no controle da poluição do ar no município são apresentados separadamente em relação a cada uma das bacias aéreas CETESB (1986).

Alguns dos estudos realizados dentro do projeto de apoio às ações de controle determinaram a adoção de medidas específicas, como, por exemplo, o estudo sobre os fluoretos, identificado como o principal agente fitotóxico que afetava a vegetação da Serra do Mar, levando à antecipação de medidas de controle de suas emissões. $\mathrm{O}$ mesmo ocorreu com os estudos sobre as emissões de amônia, bem como sobre os níveis de óxidos de enxofre na atmosfera de Cubatão. O primeiro mostrou uma grande incidência de sulfato de amônia, como material particulado fino $(<2,5 \mathrm{u})$, nas duas bacias aéreas do município, determinando medidas para a redução das emissões. O segundo evidenciou a transformação dos óxidos de enxofre em sulfatos particulados, também na forma de material particulado fino $(<2,5 \mathrm{u})$, "que representam um risco maior à saúde, por atingirem diretamente o aparelho respiratório" (CETESB, 1986, p. 13). Nesse caso, a CETESB optou, em uma primeira fase, pela redução das emissões de dióxido de enxofre provenientes das fábricas de ácido sulfúrico.

O projeto de controle também previa ações preventivas, dentre as quais disciplinar a expansão industrial para evitar o agravamento do quadro ambiental existente. Nesse aspecto, o órgão ambiental adotou o denominado "conceito bolha" na emissão de licenças para poluentes saturados, "critério de análise, segundo o qual não é permitido o aumento das emissões de um determinado poluente na bacia aérea de uma região" (CETESB, 1986, p. 21), bem como a proibição de introdução de poluentes tóxicos. Destaca-se, ainda, como medida preventiva, a "Operação 
Inverno", pela qual faz-se o acompanhamento diuturno das fontes significativas de poluição e das condições meteorológicas, visando a adoção de medidas com o objetivo de evitar a ocorrência do estado de emergência, em condições atmosféricas desfavoráveis, que pode causar riscos graves e iminentes à saúde da população. Também cabe mencionar a "Operação Verão", desenvolvida anualmente em conjunto com a defesa civil, no período de novembro a março, ou seja, na estação das chuvas, em função do risco potencial de escorregamentos de encostas, visando reduzir suas consequências.

O Programa, desde o seu início, previa medidas de curto, médio e longo prazos e, ao longo de sua implementação, sofreu diversas alterações e aperfeiçoamentos, decorrentes das avaliações periódicas dos resultados das medidas adotadas, bem como dos estudos e pesquisas realizados no município. No final do ano de 1988, por exemplo, o controle de poeiras fugitivas e o controle de algumas fontes secundárias de poluição do ar, com a identificação e autuação de 43 destas últimas, foram acrescentados às ações do Programa. A necessidade de controle das poeiras fugitivas resultou de estudo que demonstrou que estas representavam $40 \%$ na composição da qualidade do ar na região de Vila Parisi, sendo provenientes da estocagem de materiais pulverulentos a céu aberto, bem como da circulação de veículos em vias pavimentadas e não pavimentadas das áreas industriais e urbanas (CETESB, 1989).

Finda a primeira etapa do Programa, em 31/12/1989, conforme relatório da CETESB (1990), 89\% das 320 fontes autuadas em 1984 estavam controladas, com redução significativa dos poluentes atmosféricos e das águas, bem como destinação final adequada dos resíduos sólidos urbanos, hospitalares e industriais. Das fontes autuadas, somente 34 não estavam controladas até essa data, sendo 25 constituídas por fontes de poluição do ar, 05 por fontes de poluição das águas e 04 por fontes de poluição do solo. 
Tabela 10 - Redução dos poluentes atmosféricos

\begin{tabular}{|c|c|c|c|c|c|c|}
\hline \multirow[b]{2}{*}{ Poluente } & \multirow{2}{*}{$\begin{array}{c}\text { Emissão Inicial } \\
\text { (julho 84) } \\
\text { Kg/dia }\end{array}$} & \multirow{2}{*}{$\begin{array}{c}\text { Redução obtida } \\
\text { no programa } \\
\text { (jul/84 a dez/89) }\end{array}$} & \multicolumn{2}{|c|}{ Emissão Remanescente } & \multicolumn{2}{|c|}{ Nível de controle (\%) } \\
\hline & & & $\begin{array}{c}\text { Real } \\
(\text { dez/89) }\end{array}$ & $\begin{array}{l}\text { Prevista } \\
\text { (dez/89) }\end{array}$ & $\begin{array}{c}\text { Real } \\
(\mathrm{dez} / 89)\end{array}$ & $\begin{array}{l}\text { Previsto } \\
\text { (dez/89) }\end{array}$ \\
\hline M.P. (poeiras) & $316350 *$ & 238401 & 77949 & 20800 & $75^{* *}$ & 93 \\
\hline Fluor & 2620 & 2420 & 200 & 200 & 92 & 92 \\
\hline Amônia & 8736 & 8531 & 205 & 205 & 97 & 97 \\
\hline $\mathrm{NO}_{\mathrm{x}} * * *$ & 61085 & 13524 & 47561 & 47561 & 22 & 22 \\
\hline Hidrocarbonetos & 90000 & 78030 & 11970 & 11970 & 86 & 86 \\
\hline $\mathrm{SO}_{2} * * * *$ & 78353 & 28826 & 49527 & 49527 & 37 & 37 \\
\hline
\end{tabular}

* o valor foi atualizado após revisão total do inventário das fontes de poluição, em substituição à estimativa inicial (jul/1984) de $236.600 \mathrm{~kg} / \mathrm{dia}$.

** o diferencial de $18 \%$ a ser obtido no nível de controle depende exclusivamente dos sistemas faltantes na COSIPA.

*** previsto somente o controle das emissões concentradas de óxidos de nitrogênio na fabricação de ácido nítrico. **** anteriormente já havia sido obtida uma redução preliminar de $81.000 \mathrm{~kg} /$ dia deste poluente, em conseqüência da susbstituição do óleo combustível utilizado, com alto teor de enxofre, por óleo combustível com baixo teor de enxofre. Essa alteração permanece em uso, o que eleva a redução global do poluente a $69 \%$.

Fonte: CETESB, 1990.

Tabela 11 - Redução obtida dos poluentes das águas

\begin{tabular}{lrrrrrr}
\hline & $\begin{array}{c}\text { Emissão Inicial } \\
\text { (julho 84) }\end{array}$ & \multicolumn{2}{c}{$\begin{array}{c}\text { Redução obtida } \\
\text { no programa }\end{array}$} & \multicolumn{2}{c}{$\begin{array}{c}\text { Emissão Remanescente } \\
\text { Real }\end{array}$} & \multicolumn{2}{c}{ Nível de controle (\%) } \\
Pg/dia & (jul/84 a dez/89) & (dez/89) & Real & Previsto \\
Poluente & 5700 & 53280 & 3720 & 3500 & 93 & 94 \\
(dez/89) & (dez/89) \\
\hline DBO & 588 & 528 & 60 & 60 & 90 & 90 \\
RS* & 4000 & 3880 & 120 & 120 & 97 & 97 \\
Metais & 73,5 & 58,5 & 15 & 15 & 80 & 80 \\
Fenóis & 2800 & 2700 & 100 & 100 & 96 & 96 \\
Fluoretos & & & & &
\end{tabular}

$* \mathrm{~m}^{3} /$ dia.

Fonte: CETESB, 1990.

Esse relatório apontava a Companhia Siderúrgica Paulista (COSIPA) - à época, empresa estatal - como única empresa inadimplente em todos os aspectos, 
sendo responsável por 29 fontes das 34 ainda a controlar, razão pela qual o controle da emissão de material particulado previsto para ser alcançado em 31/12/89 ficou abaixo da meta inicial. As demais empresas que ainda apresentavam fontes autuadas não controladas eram a Estireno (01 fonte), a Ultrafértil SM (01 fonte), a Manah (01 fonte) e a Copebrás (02 fontes), motivo pelo qual vinham sofrendo as sanções previstas na legislação em vigor. Em todo o período dessa fase do programa (jan/84 a dez/89) foram aplicadas 256 multas às empresas do município.

No ano de 1990 iniciou-se uma nova fase do Programa de Controle da Poluição Ambiental em Cubatão intitulada "Ação Permanente de Fiscalização dos Sistemas de Controle de Poluição Instalados", visando o acompanhamento do desempenho dos sistemas implantados pelas indústrias. Essa fase também previa atuação rigorosa em relação às 34 fontes autuadas em 1984 que permaneciam inadimplentes, obtenção de avanços no controle das poeiras fugitivas e fontes secundárias de poluição do ar, estudo de necessidade de adoção de medidas complementares, identificação de riscos quanto à presença de indústrias e dutos na área urbana e identificação de possíveis pontos de lançamento clandestinos do passado, de resíduos químicos, na Bacia dos Rios Pilões e Cubatão até a barragem da SABESP (CETESB, 1990).

Em meados de 1994, segundo relatório da situação do controle da poluição no município de Cubatão elaborado pela CETESB, 91\% das fontes de poluição autuadas em 1984 estavam controladas, havendo, ainda, 20 fontes sem controle, 14 delas do ar, 04 das águas e 02 do solo. Quanto às fontes secundárias, 46\% do total estavam controladas. Segundo o relatório, no ano de 1991 foi realizada uma reavaliação quantitativa dos principais poluentes gerados pelas indústrias integrantes do Programa de Controle, bem como da carga remanescente de cada uma delas após a adoção das medidas de controle, conforme retratado nas tabelas a seguir. 
Tabela 12 - Geração dos principais poluentes atmosféricos (1984).

\begin{tabular}{|c|c|c|c|c|c|c|}
\hline \multirow[b]{2}{*}{ EMPRESAS } & \multicolumn{6}{|c|}{ POLUENTES (t/ano) } \\
\hline & Poeiras & $\mathrm{HC}$ & $\mathrm{SO}_{2}$ & $\mathrm{NO}_{\mathrm{x}}$ & Amônia & Fluoretos \\
\hline Alba (paralisada) & 21 & 1,4 & 243,5 & 96,0 & 0,0 & 0,0 \\
\hline Carbocloro & 55,1 & 2,6 & 707,4 & 28,8 & 0,0 & 0,0 \\
\hline Concrebrás & 5,8 & 0,0 & 0,0 & 0,0 & 0,0 & 0,0 \\
\hline Copebrás & $9.554,2$ & 492,8 & $1.119,8$ & 100,4 & 337,3 & 20,1 \\
\hline Cosipa & $46.847,8$ & $1.779,4$ & $6.407,9$ & $7.564,3$ & 171,9 & 0,0 \\
\hline Estireno & 72,3 & 6,2 & 834,8 & 129,6 & 0,0 & 0,0 \\
\hline Gespa & 160,2 & 1,1 & 912,5 & 71,9 & 0,0 & 0,0 \\
\hline IAP & $10.781,4$ & 0,4 & 741,0 & 21,5 & 723,4 & 352,2 \\
\hline Liquid Química & 1,5 & 235,4 & 16,8 & 6,6 & 0,0 & 0,0 \\
\hline Manah & $10.450,0$ & 0,4 & 225,2 & 22,3 & 613,2 & 311,3 \\
\hline Petrobrás-Basan & 0,0 & $2.626,2$ & 36,5 & 14,6 & 0,0 & 0,0 \\
\hline Petrobrás-RPBC & $1.460,0$ & $20.537,5$ & $6.120,3$ & $2.668,2$ & 0,0 & 0,0 \\
\hline Petrobrás-DTCS & 0,0 & $6.910,9$ & 36,5 & 14,6 & 0,0 & 0,0 \\
\hline Petrocoque & $5.693,6$ & 89,8 & 438,0 & 88,0 & 0,0 & 0,0 \\
\hline Rhodia* & 4,4 & 0,4 & 244,6 & 19,7 & 0,0 & 0,0 \\
\hline Votorantim & $2.392,6$ & 0,4 & 322,7 & 27,0 & 0,0 & 0,0 \\
\hline Solorrico & $9.837,5$ & 0,4 & 125,6 & 12,8 & 238,3 & 117,5 \\
\hline Trevo & $10.737,2$ & 0,4 & 269,0 & 25,6 & 0,0 & 0,0 \\
\hline Ultrafertil-FAF & 147,5 & 0,0 & 474,5 & $5.092,1$ & 101,5 & 0,0 \\
\hline Ultrafertil-SM & $6.162,3$ & 0,0 & $8.958,2$ & $5.782,0$ & $1.003,0$ & 155,1 \\
\hline Oxiteno & 0,4 & 0,0 & 0,0 & 0,0 & 0,0 & 0,0 \\
\hline Union Carbide & 31,4 & 120,5 & 364,3 & 510,3 & 0,0 & 0,0 \\
\hline TOTAL & $114.416,4$ & $32.806,2$ & 28.599,1 & $22.296,3$ & $3.188,6$ & 956,2 \\
\hline
\end{tabular}

*encontra-se paralisada por decisão judicial.

Fonte: CETESB, 1994. 
Tabela 13 - Carga remanescente dos principais poluentes atmosféricos (1991).

\begin{tabular}{lrrrrrr}
\hline & \multicolumn{7}{c}{ POLUENTES (t/ano) } \\
\cline { 2 - 6 } EMPRESAS & \multicolumn{1}{c}{ Poeiras } & \multicolumn{1}{c}{$\mathrm{HC}$} & \multicolumn{1}{c}{$\mathrm{SO}_{2}$} & \multicolumn{1}{c}{$\mathrm{NO}_{\mathrm{x}}$} & Amônia & Fluoretos \\
\hline Alba (paralisada) & 21,2 & 1,4 & 243,5 & 96,0 & 0,0 & 0,0 \\
Carbocloro & 22,8 & 0,45 & 330,35 & 27,65 & 0,0 & 0,0 \\
Concrebrás & 5,8 & 0,0 & 0,0 & 0,0 & 0,0 & 0,0 \\
Copebrás & $1.061,5$ & 0,0 & 923,8 & 100,4 & 9,5 & 20,1 \\
Cosipa & $24.137,1$ & $1.225,3$ & $4.435,8$ & $7.564,3$ & 11,3 & 0,0 \\
Estireno & 12,3 & 0,9 & 145,0 & 56,5 & 0,0 & 0,0 \\
Gespa & 78,8 & 1,1 & 912,5 & 71,9 & 0,0 & 0,0 \\
IAP & $1.361,0$ & 0,4 & 741,0 & 21,5 & 6,9 & 20,1 \\
Liquid Química & 1,5 & 72,3 & 16,8 & 6,6 & 0,0 & 0,0 \\
Manah & 282,1 & 0,4 & 225,2 & 22,3 & 11,0 & 17,5 \\
Petrobrás-Basan & 0,0 & 27,0 & 36,5 & 14,6 & 0,0 & 0,0 \\
Petrobrás-RPBC & 146,0 & $2.300,6$ & $6.120,3$ & $2.668,2$ & 0,0 & 0,0 \\
Petrobrás-DTCS & 0,0 & 157,3 & 36,5 & 14,6 & 0,0 & 0,0 \\
Petrocoque & 206,9 & 89,8 & 438,0 & 88,0 & 0,0 & 0,0 \\
Rhodia* & 4,4 & 0,4 & 244,6 & 19,7 & 0,0 & 0,0 \\
Votorantim & 73,0 & 0,4 & 322,7 & 27,0 & 0,0 & 0,0 \\
Solorrico & $1.662,6$ & 0,4 & 125,6 & 12,8 & 3,3 & 6,6 \\
Trevo & $1.269,8$ & 0,4 & 269,0 & 25,6 & 0,0 & 0,0 \\
Ultrafertil-FAF & 66,4 & 0,0 & 474,5 & $1.011,4$ & 11,3 & 0,0 \\
Ultrafertil-SM & $1.200,8$ & 0,0 & 604,8 & $4.926,4$ & 21,5 & 8,8 \\
Union Carbide & 31,4 & 120,5 & 364,3 & 510,3 & 0,0 & 0,0 \\
& & & & & & \\
TOTAL & $\mathbf{3 1 . 6 4 5 , 4}$ & $\mathbf{3 . 9 9 9 , 1}$ & $\mathbf{1 7 . 0 1 0 , 8}$ & $\mathbf{1 7 . 2 8 5 , 6}$ & $\mathbf{7 4 , 8}$ & $\mathbf{7 3 , 1}$ \\
\hline Nonyyyyy & & & & & \\
\hline
\end{tabular}

*encontra-se paralisada por decisão judicial.

Fonte: CETESB, 1994. 
Tabela 14 - Geração dos principais poluentes das águas (1984)

\begin{tabular}{lrrrrr}
\hline & \multicolumn{5}{c}{ POLUENTES (t/ano) } \\
\cline { 2 - 6 } EMPRESAS & \multicolumn{1}{c}{ Carga } & \multicolumn{1}{c}{ Metais } & & \multicolumn{2}{c}{ Resíduos } \\
Orgânica & Pesados & Fluoretos & Fenóis & Sedimentáveis** \\
\hline Alba (paralisada) & 17,5 & 0,0 & 0,0 & 0,0 & 0,0 \\
Carbocloro & 399,3 & 6,6 & 0,0 & 0,0 & 0,0 \\
Copebrás & 93,4 & 0,0 & 200,8 & 0,0 & 111,0 \\
Cosipa & $6.528,8$ & $1.336,6$ & 79,6 & 10,0 & 39,1 \\
Estireno & 307,3 & 0,0 & 0,0 & 0,0 & 0,0 \\
IAP & 10,2 & 0,0 & 190,2 & 0,0 & 0,4 \\
Liquid Química & 148,9 & 60,6 & 0,0 & 1,5 & 0,0 \\
Manah & 377,8 & 0,0 & 310,6 & 0,0 & 31,0 \\
Petrobrás-RPBC & $13.694,8$ & 61,7 & 0,0 & 15,3 & 32,1 \\
Rhodia* & 40,5 & 0,0 & 0,0 & 0,0 & 0,0 \\
Santista Papel & 92,7 & 0,0 & 0,0 & 0,0 & 0,7 \\
Solorrico & 19,7 & 0,0 & 240,9 & 0,0 & 1,1 \\
Ultrafertil-FAF & 239,1 & 0,0 & 0,0 & 0,0 & 0,0 \\
Ultrafertil-SM & 216,4 & 0,0 & 254,4 & 0,0 & 0,0 \\
Union Carbide & 492,0 & 1,8 & 0,0 & 0,0 & 0,4 \\
& & & & & $\mathbf{2 1 5 , 8}$ \\
TOTAL & $\mathbf{2 2 . 6 7 8 , 4}$ & $\mathbf{1 . 4 6 7 , 3}$ & $\mathbf{1 . 2 7 6 , 5}$ & $\mathbf{2 6 , 8}$ &
\end{tabular}

Tabela 15 - Carga remanescente dos principais poluentes das águas (1991).

\begin{tabular}{lrrrrr}
\hline & \multicolumn{5}{c}{ POLUENTES (t/ano) } \\
\cline { 2 - 6 } EMPRESAS & $\begin{array}{c}\text { Carga } \\
\text { Orgânica }\end{array}$ & $\begin{array}{c}\text { Metais } \\
\text { Pesados }\end{array}$ & Fluoretos & Fenóis & $\begin{array}{c}\text { Resíduos } \\
\text { Sedimentáveis** }\end{array}$ \\
\hline Alba (paralisada) & 1,8 & 0,0 & 0,0 & 0,0 & 0,0 \\
Carbocloro & 56,2 & 1,8 & 0,0 & 0,0 & 0,0 \\
Copebrás & 18,7 & 0,0 & 19,7 & 0,0 & 8,4 \\
Cosipa & 587,3 & 30,7 & 8,0 & 3,3 & 5,8 \\
Estireno & 82,1 & 0,0 & 0,0 & 0,0 & 0,0 \\
IAP & 10,2 & 0,0 & 17,5 & 0,0 & 0,0 \\
Liquid Química & 0,7 & 5,1 & 0,0 & 0,0 & 0,0 \\
Manah & 19,7 & 0,0 & 29,6 & 0,0 & 4,0 \\
Petrobrás-RPBC & 688,0 & 6,2 & 0,0 & 1,4 & 3,3 \\
Rhodia* & 2,2 & 0,0 & 0,0 & 0,0 & 0,0 \\
Santista Papel & 9,3 & 0,0 & 0,0 & 0,0 & 0,0 \\
Solorrico & 3,9 & 0,0 & 0,0 & 0,0 & 0,0 \\
Ultrafertil-FAF & 18,3 & 0,0 & 0,0 & 0,0 & 0,0 \\
Ultrafertil-SM & 43,1 & 0,0 & 25,2 & 0,0 & 0,0 \\
\hline
\end{tabular}


Union Carbide

TOTAL

*paralisada por

O

O índice de qualidade do ar para partículas inaláveis, entretanto, continuava muito acima do padrão legal $\left(50 \mathrm{ug} / \mathrm{m}^{3}\right)$ na região de Cubatão-Vila Parisi (129 ug/m3) e as reclamações da comunidade quanto a episódios de emissões odoríferas provenientes de processos industriais continuavam bastante altas, sendo recebidas 376 reclamações no ano de 1993, sendo 184 (49\%) relacionadas à empresa Petrobrás-RPBC.

Quanto ao controle da poluição do solo, que teve como objetivo inicial romper o ciclo de disposição inadequada de resíduos, conforme o mesmo relatório, do total de 4.767.289,4 t/ano de resíduos sólidos gerados pelas indústrias, apenas 1.629.782,0 continuavam sendo dispostos de maneira inadequada, quase em sua totalidade pela COSIPA, com algumas iniciativas visando a adoção de processos de reciclagem e reutilização de resíduos, especialmente pelas indústrias de fertilizantes do município. Os resíduos de natureza doméstica vinham sendo dispostos em aterro sanitário, enquanto os hospitalares eram incinerados em sistema operado pela municipalidade, com a aprovação do órgão ambiental.

No que se refere à empresa COSIPA, o relatório da CETESB de 1994 noticiou que esta havia formalizado Termo de Compromisso com o órgão ambiental, obrigando-se à adoção de medidas de curto, médio e longo prazos, visando controlar as fontes primárias inadimplentes, iniciar o controle das fontes secundárias, melhorar o controle das poeiras fugitivas, revisar os sistemas de controle já implantados, regularizar as pendências de licenciamento e apresentar análises de risco para as unidades de maior potencial de acidentes ambientais.

Segundo o mesmo relatório, as demais medidas de controle também prosseguiam, dentre as quais o controle das poeiras fugitivas, controle de opacidade e saneamento da área de Pilões, verificando-se a recuperação da qualidade das águas, diminuição expressiva de episódios críticos de poluição do ar, recuperação da Serra do Mar e substancial minimização de episódios de odor em Cubatão-Centro.

Conforme informações obtidas junto ao órgão ambiental, a despeito da continuidade das ações do Programa em Cubatão, com as alterações e 
aperfeiçoamentos necessários, desde 1994 não mais foram publicados relatórios técnicos dos resultados advindos dessas ações, sendo realizadas apenas audiências públicas até o ano de 1998, porém sem o correspondente registro, e feitas apresentações na Câmara de Vereadores do município, nos anos de 2003 e 2004, para prestação de contas da evolução do Programa à comunidade. A falta de continuidade do processo de documentação dessa evolução é atribuída ao aumento da demanda de fiscalização e controle, somada à falta de recursos humanos suficientes e capacitados para essa atividade no órgão ambiental.

Comparando-se com as situações ocorridas em outros países apresentadas no item 2.4 deste trabalho (Estados Unidos, Inglaterra e Japão), verifica-se que a solução encontrada para Cubatão, por meio do Programa de Controle da Poluição Ambiental, foi semelhante às experiências vividas pela Inglaterra e Japão, no que se refere à necessidade de ações fundamentadas em uma legislação forte, impondo a adoção de medidas corretivas e preventivas pelas empresas, embora aquelas digam respeito a políticas públicas nacionais, ao contrário do Programa, criado para atender à situação específica de uma localidade. Também se assemelha a importância das pressões da sociedade civil no processo de melhoria do controle da poluição, com participação fundamental da mídia. Contudo, naqueles países os governos locais desempenharam papel fundamental, inclusive com a edição de normas específicas para o controle da poluição, enquanto no caso de Cubatão esse papel foi desempenhado quase exclusivamente pelo governo estadual, com pouca ou nenhuma participação do governo municipal, e algum apoio do governo federal.

Nos Estados Unidos, a despeito de se tratar de um problema localizado, como o de Cubatão, a solução encontrada foi diferente, baseando-se na adoção de medidas de recuperação pelo próprio governo, com grande cooperação entre os governos local, estadual e federal, os quais responderam rapidamente com medidas para a solução do problema, em especial disponibilizando ajuda financeira. 


\subsection{DESCRIÇÃO E AVALIAÇÃO DA EVOLUÇÃO DOS INDICADORES AMBIENTAIS, ECONÔMICOS, SOCIAIS E INSTITUCIONAIS DE CUBATÃO}

Neste item é apresentada a evolução dos indicadores ambientais, econômicos, sociais e institucionais selecionados na pesquisa para demonstrar os resultados alcançados no município de Cubatão, a partir do Programa de Controle da Poluição Ambiental iniciado pela CETESB em 1983, até o ano de 2005, sob o enfoque do desenvolvimento sustentável.

No que se refere à evolução dos indicadores ambientais relacionados à poluição do ar, a figura e os quadros apresentados trazem as informações somente a partir do ano de 1985 até o ano de 2005, período para o qual existiam dados disponíveis. Os dados das emissões anuais de cada um dos poluentes e os dados de qualidade do ar foram obtidos nos relatórios de qualidade do ar no Estado de São Paulo elaborados anualmente pela CETESB.

Na Figura 2 é possível verificar a redução global obtida em Cubatão nas emissões dos poluentes atmosféricos selecionados para a pesquisa, de 1985 a 2005. O ano de 1988 não consta da figura, uma vez que o relatório de qualidade do ar respectivo não traz a informação.

Importante mencionar, conforme esclarecimentos obtidos junto ao órgão ambiental, que a CETESB não faz inventário anual das emissões de poluentes atmosféricos no município, motivo pelo qual os valores das estimativas de emissões são repetidos em alguns anos, como foi o que ocorreu, por exemplo, nos anos de 1990 a 1994. 
Figura 2 - Estimativa de emissões dos poluentes atmosféricos material particulado (MP), dióxido de enxofre $\left(\mathrm{SO}_{2}\right)$, óxidos de nitrogênio $\left(\mathrm{NO}_{\mathrm{x}}\right)$ e hidrocarbonetos (HC) no período compreendido entre 1985 e 2005.

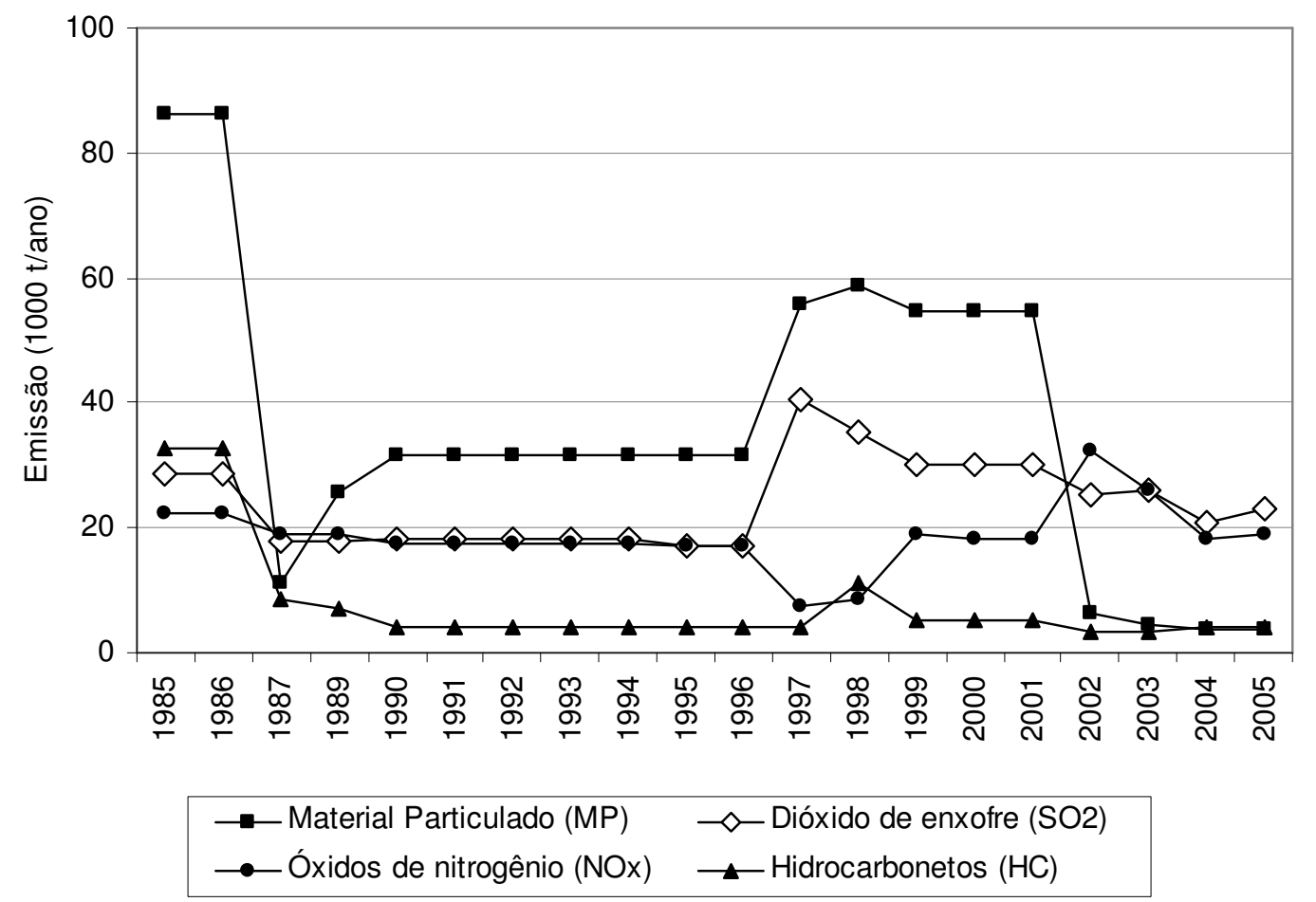

Fonte: CETESB, 1985 a 2005. 
Analisando a Figura acima é possível verificar que, da fase inicial do programa até o ano de 1987, houve uma grande redução das emissões globais dos poluentes atmosféricos no município de Cubatão. Após esse ano, teria havido uma estabilização das emissões, com considerável aumento das emissões de material particulado e dióxido de enxofre no ano de 1997. As emissões de dióxido de enxofre, a partir da alta ocorrida em 1997 vêm se reduzindo gradativamente. Já as emissões de material particulado teriam permanecido bastante altas até o ano de 2002 quando, segundo os dados da CETESB, teriam apresentado redução drástica. Os óxidos de nitrogênio apresentaram ligeira alta no ano de 1999 e nova alta em 2002, voltando a cair em 2004. As emissões de hidrocarbonetos tiveram uma ligeira alta em 1998, voltando aos patamares anteriores em 1999, estabilizando-se daí para frente. A redução global obtida para a emissão desses poluentes, do início do programa até o ano 2005 , foi de aproximadamente $70 \%$.

Nos Quadros 1 e 2 é possível observar a evolução da distribuição anual do índice geral de qualidade do ar para as duas bacias áreas do município (CubatãoCentro e Cubatão Vila Parisi), no período de 1985 a 2005. Os anos de 1989 e 1990 não constam dos quadros, uma vez que os relatórios de qualidade do ar respectivos não trazem a informação.

A distribuição anual do índice geral de qualidade do ar é efetuada com base nos boletins diários de qualidade do ar, os quais são elaborados a partir dos dados de qualidade do ar obtidos pela CETESB em suas estações automáticas de monitoramento, juntamente com uma previsão meteorológica das condições de dispersão dos poluentes para as 24 horas seguintes. Esse índice contempla os seguintes parâmetros: dióxido de enxofre, partículas totais em suspensão, partículas inaláveis, fumaça, monóxido de carbono, ozônio e dióxido de nitrogênio. Para cada poluente medido é calculado um índice, sendo utilizado para efeito de divulgação o índice mais elevado, isto é, a qualidade do ar de uma estação é determinada pelo pior caso. Depois de calculado o valor do índice, o ar recebe uma qualificação. A ultrapassagem do padrão de qualidade do ar é identificada pela qualidade inadequada. A qualidade má indica a ultrapassagem do nível de atenção, a péssima, indica a ultrapassagem do nível de alerta e a crítica, a ultrapassagem do nível de 
emergência. Esta qualificação do ar está associada com efeitos sobre à saúde, independentemente do poluente em questão, conforme Tabela 16 (CETESB, 2005).

Tabela 16 - Índice de qualidade do ar e efeitos sobre a saúde.

\begin{tabular}{|c|c|c|}
\hline Qualidade & Índice & Significado \\
\hline Boa & $0-50$ & Praticamente não há riscos à saúde. \\
\hline Regular & $51-100$ & $\begin{array}{l}\text { Pessoas de grupos sensíveis (crianças, idosos e pessoas com doenças respiratórias e } \\
\text { cardíacas), podem apresentar sintomas como tosse seca e cansaço. A população, em } \\
\text { geral, não é afetada. }\end{array}$ \\
\hline Inadequada & $101-199$ & $\begin{array}{l}\text { Toda a população pode apresentar sintomas como tosse seca, cansaço, ardor nos } \\
\text { olhos, nariz e garganta. Pessoas de grupos sensíveis (crianças, idosos e pessoas com } \\
\text { doenças respiratórias e cardíacas), podem apresentar efeitos mais sérios na saúde. }\end{array}$ \\
\hline Má & $200-299$ & $\begin{array}{l}\text { Toda a população pode apresentar agravamento dos sintomas como tosse seca, } \\
\text { cansaço, ardor nos olhos, nariz e garganta e ainda apresentar falta de ar e } \\
\text { respiração ofegante. Efeitos ainda mais graves à saúde de grupos sensíveis } \\
\text { (crianças, idosos e pessoas com doenças respiratórias e cardíacas). }\end{array}$ \\
\hline Péssima & $>299$ & $\begin{array}{l}\text { Toda a população pode apresentar sérios riscos de manifestações de doenças } \\
\text { respiratórias e cardiovasculares. Aumento de mortes prematuras em pessoas de } \\
\text { grupos sensíveis. }\end{array}$ \\
\hline
\end{tabular}

Fonte: CETESB, 2007.

Quadro 1 - Distribuição anual do índice geral de qualidade do ar em Cubatão-Centro

\begin{tabular}{|c|c|c|c|c|c|c|c|}
\cline { 2 - 9 } \multicolumn{1}{c|}{} & \multicolumn{9}{c|}{ Qualidade do ar considerando o número de dias monitorados durante o } \\
ano, em percentagem de tempo & & \\
\hline & $\begin{array}{c}\text { N. } \begin{array}{c}\text { Total de } \\
\text { dias } \\
\text { Ano }\end{array} \\
\text { monitorados }\end{array}$ & Boa & Regular & Inadequada & Má & Péssima & Crítica \\
\hline 1985 & 356 & 30,0 & 58,4 & 8,8 & 2,5 & - & 0,3 \\
\hline 1986 & 360 & 38,0 & 52,8 & 7,5 & 1,7 & - & - \\
\hline 1987 & 338 & 29,3 & 59,8 & 8,3 & 2,6 & - & - \\
\hline 1988 & 347 & 18,4 & 72,0 & 6,4 & 3,2 & - & - \\
\hline 1991 & 291 & 35,4 & 60,1 & 3,1 & 1,4 & - & - \\
\hline 1992 & 323 & 39,9 & 58,2 & 1,3 & 0,6 & - & - \\
\hline 1993 & 329 & 69,0 & 29,8 & 0,9 & 0,3 & - & - \\
\hline $1994 *$ & 92 & 93,5 & 6,5 & - & - & - & - \\
\hline 1995 & 313 & 47,0 & 52,0 & 1,0 & - & - & - \\
\hline $1996 *$ & 254 & 46,1 & 52,8 & 1,2 & - & - & - \\
\hline 1997 & 344 & 50,6 & 44,8 & 3,2 & 1,5 & - & - \\
\hline 1998 & 338 & 63,6 & 33,7 & 2,1 & 0,6 & - & - \\
\hline 1999 & 364 & 53,8 & 42,0 & 3,3 & 0,8 & - & - \\
\hline 2000 & 353 & 55,2 & 42,8 & 1,4 & 0,6 & - & - \\
\hline 2001 & 363 & 42,1 & 53,2 & 3,9 & 0,8 & - & - \\
\hline 2002 & 227 & 44,5 & 47,6 & 5,7 & 2,2 & - & - \\
\hline 2003 & 334 & 51,2 & 44,0 & 3,0 & 1,8 & - & - \\
\hline 2004 & 350 & 74,3 & 25,1 & 0,3 & 0,3 & - & - \\
\hline 2005 & 357 & 70,0 & 28,9 & 0,8 & 0,3 & - & - \\
\hline
\end{tabular}

*não atende aos critérios de representatividade 
Fonte: CETESB, 1985 a 2005.

Analisando o quadro acima, verifica-se que até o ano de 2005 (limite da pesquisa) continuaram a ocorrer ultrapassagens dos padrões de qualidade do ar, identificadas pela qualidade inadequada, em Cubatão-Centro, bem como ultrapassagens do nível de atenção, indicado pela qualidade má, embora tenha havido a redução do tempo em que esses fenômenos ocorrem em relação ao início da implementação do programa. O percentual de tempo em que a qualidade do ar está boa (70\%), em relação ao início do programa (30\%), é bastante significativa, não se verificando mais, desde 1986, as condições péssima ou crítica nessa bacia aérea, onde se situa a área urbana residencial do município.

Quadro 2 - Distribuição anual do índice geral de qualidade do ar em Cubatão-Vila Parisi

\begin{tabular}{|c|c|c|c|c|c|c|c|}
\cline { 2 - 9 } \multicolumn{1}{c|}{} & \multicolumn{7}{c|}{ Qualidade do ar considerando o número de dias monitorados durante o } \\
\hline & $\begin{array}{c}\text { No. Total } \\
\text { ano, em percentagem de tempo }\end{array}$ & & & \\
\hline Ano & monitorados & Boa & Regular & Inadequada & Má & Péssima & Crítica \\
\hline 1985 & 350 & 7,5 & 36,3 & 34,6 & 16,5 & 4,5 & 0,6 \\
\hline 1986 & 336 & 5,8 & 38,4 & 34,0 & 19,7 & 2,1 & - \\
\hline 1987 & 325 & 4,7 & 52,6 & 24,6 & 16,0 & 2,1 & - \\
\hline 1988 & 315 & 7,5 & 51,7 & 28,2 & 11,4 & 1,2 & - \\
\hline 1991 & 332 & 8,1 & 48,8 & 32,8 & 9,3 & 0,6 & 0,3 \\
\hline 1992 & 338 & 20,7 & 68,3 & 10,7 & 0,3 & - & - \\
\hline 1993 & 354 & 4,5 & 65,5 & 26,6 & 3,4 & - & - \\
\hline 1994 & 342 & 2,6 & 29,8 & 49,1 & 17,8 & 0,3 & 0,3 \\
\hline 1995 & 325 & 0,3 & 49,5 & 39,7 & 10,5 & - & - \\
\hline $1996 *$ & 285 & 15,1 & 74,0 & 10,2 & 0,7 & - & - \\
\hline 1997 & 360 & 13,6 & 73,1 & 12,5 & 0,8 & - & - \\
\hline 1998 & 329 & 16,4 & 72,0 & 11,6 & - & - & - \\
\hline 1999 & 332 & 24,1 & 67,8 & 7,8 & 0,3 & - & - \\
\hline 2000 & 344 & 19,5 & 73,3 & 7,3 & - & - & - \\
\hline 2001 & 363 & 14,9 & 78,0 & 6,9 & 0,3 & - & - \\
\hline 2002 & 363 & 16,5 & 79,1 & 4,4 & - & - & - \\
\hline 2003 & 365 & 10,7 & 74,0 & 14,8 & 0,5 & - & - \\
\hline 2004 & 364 & 17,6 & 75,8 & 6,6 & - & - & - \\
\hline
\end{tabular}




\begin{tabular}{|l|l|l|l|l|l|l|l|}
\hline 2005 & 363 & 19,6 & 70,0 & 9,9 & 0,6 & - & - \\
\hline
\end{tabular}

*não atende aos critérios de representatividade

Fonte: CETESB, 1985 a 2005.

No Quadro 2 observa-se a distribuição anual do índice geral de qualidade do ar para Cubatão-Vila Parisi, região na qual estão estabelecidas a maioria das indústrias que compõem o pólo industrial. As informações desse quadro demonstram que as ultrapassagens dos padrões de qualidade do ar, identificadas pela qualidade inadequada, ocorrem com maior freqüência que em Cubatão-Centro, bem como ultrapassagens do nível de atenção, indicado pela qualidade má. Verifica-se que também houve redução do tempo em que esses fenômenos ocorrem em relação ao início da implementação do programa, assim como melhoria do percentual de tempo em que a qualidade do ar está boa. Contudo, essa melhoria não alcançou os mesmos índices de Cubatão-Centro, posto que a condição boa, que representa a melhor condição, ocorreu em menos de $20 \%$ do tempo em 2005. As condições péssima ou crítica nessa bacia aérea, por sua vez, somente deixaram de ocorrer a partir do ano de 1995, quase dez anos depois da bacia de Cubatão-Centro.

As distribuições anuais da qualidade do ar para os parâmetros ozônio e partículas inaláveis em Cubatão-Centro e para o parâmetro partículas inaláveis em Cubatão-Vila Parisi, no período de 1985 a 2005, são apresentadas nos Quadros 3 e 4. O ano de 1990 não consta dos quadros, uma vez que o relatório de qualidade do ar respectivo não traz a informação.

A apresentação dos resultados da evolução da distribuição anual da qualidade do ar para esses parâmetros é considerada importante pelo fato de se tratarem dos poluentes mais problemáticos nas respectivas bacias áreas, bem como por permitir a comparação com a evolução das emissões, considerando-se, ainda, os critérios utilizados pela CETESB para determinar a qualidade do ar de uma estação, ou seja, utiliza-se o pior caso, o índice mais elevado para cada poluente medido (CETESB, 2005).

Importante esclarecer que o ozônio não se trata de um poluente primário, ou seja, não é emitido diretamente pelas fontes de emissão, tratando-se de um poluente secundário. Os poluentes secundários são aqueles formados na atmosfera através da 
reação química entre poluentes primários e/ou constituintes naturais da atmosfera. O ozônio é um poluente formado pela reação fotoquímica ocorrida na atmosfera entre os óxidos de nitrogênio e hidrocarbonetos (BRANCO, 1984).

Quadro 3 - Distribuição anual da qualidade do ar em Cubatão-Centro para o parâmetro Ozônio $\left(\mathrm{O}_{3}\right)$

\begin{tabular}{|c|c|c|c|c|c|c|c|}
\hline \multirow[b]{2}{*}{ Ano } & \multicolumn{7}{|c|}{$\begin{array}{c}\text { Qualidade do ar considerando o número de dias monitorados durante o } \\
\text { ano, em percentagem de tempo }\end{array}$} \\
\hline & $\begin{array}{c}\mathrm{N}^{\mathrm{o}} \text {. Total } \\
\text { de dias } \\
\text { monitorados }\end{array}$ & Boa & Regular & Inadequada & Má & Péssima & Crítica \\
\hline 1985 & 347 & 77,4 & 20,2 & 2,1 & 0,3 & - & - \\
\hline 1986 & 295 & 41,0 & 48,1 & 8,8 & 2,1 & - & - \\
\hline 1987 & 292 & 46,9 & 42,5 & 7,5 & 3,1 & - & - \\
\hline 1988 & 335 & 56,4 & 37,3 & 3,3 & 3,0 & - & - \\
\hline 1989 & 286 & 65,7 & 28,7 & 3,5 & 2,1 & - & - \\
\hline 1991 & 195 & 66,7 & 28,7 & 3,1 & 1,5 & - & - \\
\hline 1992 & 245 & 94,8 & 4,0 & 0,4 & 0,8 & - & - \\
\hline 1993 & 170 & 91,8 & 7,1 & 1,2 & - & - & - \\
\hline 1994* & 19 & 94,7 & 5,3 & - & - & - & - \\
\hline $1995^{*}$ & $*$ & $*$ & $*$ & $*$ & $*$ & - & - \\
\hline 1996* & 136 & 50,7 & 47,1 & 2,2 & - & - & - \\
\hline 1997* & 250 & 57,6 & 36,4 & 4,0 & 2,0 & - & - \\
\hline 1998 & 293 & 66,6 & 30,7 & 2,0 & 0,7 & - & - \\
\hline 1999 & 350 & 57,4 & 38,9 & 2,9 & 0,9 & - & - \\
\hline 2000 & 333 & 63,1 & 35,1 & 1,2 & 0,6 & - & - \\
\hline 2001 & 361 & 46,5 & 49,0 & 3,6 & 0,8 & - & - \\
\hline $2002^{*}$ & 210 & 42,4 & 49,0 & 6,2 & 2,4 & - & - \\
\hline
\end{tabular}




\begin{tabular}{|c|c|c|c|c|c|c|c|}
\hline 2003 & 316 & 50,9 & 44,3 & 2,8 & 1,9 & - & - \\
\hline $2004 *$ & 293 & 76,5 & 22,9 & 0,3 & 0,3 & - & - \\
\hline 2005 & 345 & 73,6 & 25,5 & 0,6 & 0,3 & - & - \\
\hline
\end{tabular}

*não atende aos critérios de representatividade

Fonte: CETESB, 1985 a 2005.

Verifica-se no Quadro 3 que até o ano de 2005 (limite da pesquisa) continuaram ocorrendo ultrapassagens do padrão de qualidade do ar, identificadas pela qualidade inadequada, para o parâmetro ozônio em Cubatão-Centro, bem como ultrapassagens do nível de atenção, indicado pela qualidade má. Houve redução do tempo em que ocorrem as ultrapassagens do padrão de qualidade em relação ao início da implementação do programa, permanecendo, porém, praticamente inalteradas as demais condições.

Quadro 4 - Distribuição anual da qualidade do ar em Cubatão-Centro para o parâmetro Partículas Inaláveis (PI)

\begin{tabular}{|c|c|c|c|c|c|c|c|}
\hline \multirow[b]{2}{*}{ Ano } & \multicolumn{7}{|c|}{$\begin{array}{l}\text { Qualidade do ar considerando o número de dias monitorados durante o } \\
\text { ano, em percentagem de tempo }\end{array}$} \\
\hline & $\begin{array}{c}\mathrm{N}^{\mathbf{o}} . \text { Total } \\
\text { de dias } \\
\text { monitorados }\end{array}$ & Boa & Regular & Inadequada & Má & Péssima & Crítica \\
\hline 1985 & 346 & 43,9 & 50,0 & 5,8 & - & - & 0,3 \\
\hline 1986 & 257 & 41,2 & 57,6 & 1,2 & - & - & - \\
\hline 1987 & 314 & 37,3 & 60,8 & 1,9 & - & - & - \\
\hline 1988 & 334 & 17,1 & 78,4 & 4,2 & 0,3 & - & - \\
\hline 1989 & 206 & 32,5 & 67,0 & 0,5 & - & - & - \\
\hline 1991 & 274 & 36,1 & 62,4 & 1,1 & 0,4 & - & - \\
\hline 1992 & 317 & 39,4 & 59,6 & 0,9 & - & - & - \\
\hline 1993 & 305 & 67,2 & 32,1 & 0,3 & 0,3 & - & - \\
\hline 1994* & 59 & 91,5 & 8,5 & - & - & - & - \\
\hline 1995 & 313 & 47,0 & 52,0 & 1,0 & - & - & - \\
\hline 1996* & 254 & 59,8 & 40,2 & - & - & - & - \\
\hline 1997 & 344 & 70,9 & 28,8 & 0,3 & - & - & - \\
\hline 1998 & 311 & 79,1 & 20,6 & 0,3 & - & - & - \\
\hline 1999 & 362 & 83,7 & 15,7 & 0,6 & - & - & - \\
\hline 2000 & 351 & 78,1 & 21,7 & 0,3 & - & - & - \\
\hline 2001 & 355 & 84,7 & 15,0 & 0,3 & - & - & - \\
\hline 2002 & 227 & 92,5 & 7,5 & - & - & - & - \\
\hline
\end{tabular}




\begin{tabular}{|l|l|l|c|c|c|c|c|}
\hline 2003 & 327 & 89,3 & 10,4 & 0,3 & - & - & - \\
\hline 2004 & 348 & 90,5 & 9,5 & - & - & - & - \\
\hline 2005 & 294 & 90,8 & 8,8 & 0,3 & - & - & - \\
\hline
\end{tabular}

*não atende aos critérios de representatividade

Fonte: CETESB, 1985 a 2005.

O parâmetro partículas inaláveis apresenta menores problemas que o ozônio em Cubatão-Centro, conforme pode ser observado no Quadro 4, verificando-se considerável redução das ultrapassagens do padrão de qualidade do ar, identificadas pela qualidade inadequada, registrando-se a última ocorrência de ultrapassagem do nível de atenção, indicado pela qualidade má, no ano de 1993. Os dados demonstram, ainda, melhoria geral da qualidade do ar para esse parâmetro, verificada pela evolução da condição boa, que ocorria em apenas 43,9\% do tempo no início da implementação do programa, sendo que em 2005 o percentual obtido foi de 90,8\%.

Quadro 5 - Distribuição anual da qualidade do ar em Cubatão-Vila Parisi para o parâmetro Partículas Inaláveis (PI)

\begin{tabular}{|c|c|c|c|c|c|c|c|}
\hline \multirow[b]{2}{*}{ Ano } & \multicolumn{7}{|c|}{$\begin{array}{c}\text { Qualidade do ar considerando o número de dias monitorados durante o } \\
\text { ano, em percentagem de tempo }\end{array}$} \\
\hline & $\begin{array}{c}\mathrm{N}^{\mathbf{o}} . \text { Total } \\
\text { de dias } \\
\text { monitorados }\end{array}$ & Boa & Regular & Inadequada & Má & Péssima & Crítica \\
\hline 1985 & 342 & 5,6 & 36,8 & 35,4 & 17,0 & 4,7 & 0,6 \\
\hline 1986 & 332 & 4,2 & 38,9 & 35,3 & 19,5 & 2,1 & - \\
\hline 1987 & 321 & 3,4 & 53,3 & 24,9 & 16,2 & 2,2 & - \\
\hline 1988 & 311 & 6,1 & 52,4 & 28,6 & 11,6 & 1,3 & - \\
\hline 1989 & 333 & 3,3 & 68,5 & 23,7 & 4,5 & - & - \\
\hline 1991 & 329 & 7,3 & 49,2 & 33,1 & 9,4 & 0,6 & 0,3 \\
\hline 1992 & 332 & 19,3 & 69,6 & 1,8 & 0,3 & - & - \\
\hline 1993 & 350 & 3,4 & 66,3 & 26,9 & 3,4 & - & - \\
\hline 1994 & 334 & 0,3 & 30,5 & 50,3 & 18,3 & 0,3 & 0,3 \\
\hline 1995 & 324 & 0,0 & 49,7 & 39,8 & 10,5 & - & - \\
\hline 1996* & 285 & 15,1 & 74,0 & 10,2 & 0,7 & - & - \\
\hline 1997 & 360 & 13,6 & 73,1 & 12,5 & 0,8 & - & - \\
\hline 1998 & 329 & 16,4 & 72,0 & 11,6 & - & - & - \\
\hline 1999 & 330 & 23,6 & 68,2 & 7,9 & 0,3 & - & - \\
\hline 2000 & 344 & 19,5 & 73,3 & 7,3 & - & - & - \\
\hline 2001 & 358 & 13,7 & 79,1 & 7,0 & 0,3 & - & - \\
\hline 2002 & 361 & 16,1 & 79,5 & 4,4 & - & - & - \\
\hline 2003 & 364 & 10,4 & 74,2 & 14,8 & 0,5 & - & - \\
\hline 2004 & 358 & 17,6 & 75,7 & 6,7 & - & - & - \\
\hline
\end{tabular}




\begin{tabular}{|l|l|l|l|l|l|l|l|}
\hline 2005 & 355 & 20,0 & 69,3 & 10,1 & 0,6 & - & - \\
\hline
\end{tabular}

*não atende aos critérios de representatividade

Fonte: CETESB, 1985 a 2005.

O Quadro 5 demonstra que, apesar da qualidade do ar para o parâmetro partículas inaláveis ter apresentado melhoria em Cubatão-Vila Parisi, este continua a ser o principal problema dessa bacia aérea. Embora tenha havido redução nas ultrapassagens do padrão de qualidade do ar para esse parâmetro, identificadas pela qualidade inadequada, esse fato continuou a ocorrer em 10,1\% do tempo no ano de 2005. Entretanto, houve considerável melhoria das ultrapassagens do nível de atenção, indicado pela qualidade má, não sendo registradas situações de alerta ou emergência desde 1994. O percentual de tempo em que a condição boa é registrada, por seu turno, foi alcançada em apenas 20\% do tempo no ano de 2005.

Comparando-se a Figura 2 com os quadros demonstrativos da evolução da qualidade do ar, verifica-se que não é possível estabelecer relação clara entre a redução e/ou aumento das emissões com a melhoria ou piora da qualidade do ar. Observa-se, por exemplo, na Figura 2, ter ocorrido considerável redução das emissões de material particulado no ano de 2002. Entretanto, a melhoria da qualidade do ar para o parâmetro partículas inaláveis em Cubatão-Vila Parisi, nesse ano, em relação ao ano de 2001, foi pequena, tendo havido piora no ano de 2003, que apresentou mais que o dobro das ultrapassagens de padrão ocorridas no ano de 2001, embora as estimativas de emissões não evidenciem qualquer aumento nesse ano, mas até alguma redução das emissões em relação ao ano de 2002. Essa aparente incoerência pode ser resultante da ocorrência de melhores ou piores condições de dispersão dos poluentes nesses anos - aspecto que também é levado em conta no estabelecimento da qualidade do ar - ou da contribuição de outras fontes não consideradas nas estimativas de emissões, especialmente fontes difusas. Pode, também, decorrer do fato das estimativas de emissões não representarem a realidade, face à não realização de inventário anual das emissões de poluentes atmosféricos no município pelo órgão ambiental, conforme já mencionado (item 4.2).

Esses indicadores permitem concluir que houve considerável redução das emissões globais de poluentes atmosféricos em Cubatão, do início do programa, em 
1983, até o ano de 2005, com reflexos positivos na melhoria geral da qualidade do ar nas duas bacias aéreas do município (Cubatão-Centro e Cubatão-Vila Parisi). Entretanto, considerando que o objetivo básico do projeto inicial de controle era reduzir as emissões de poluentes do ar e águas das fontes existentes na região, de modo a garantir o atendimento aos respectivos padrões de qualidade, esse objetivo ainda não havia sido plenamente atendido, uma vez que continuavam ocorrendo ultrapassagens dos padrões de qualidade do ar, com registros de nível de atenção, nas duas bacias áreas, em especial em Cubatão-Vila Parisi, na qual os padrões de qualidade não eram atendidos em pouco mais de $10 \%$ do tempo.

Esse resultado pode indicar, ainda, que os padrões legais de emissão não vêm sendo atendidos em tempo integral pelas empresas que compõem o pólo industrial de Cubatão, ou, caso esse fato venha efetivamente ocorrendo, a necessidade do estabelecimento de padrões de emissão mais restritos para o município que considerem as características específicas deste.

No Quadro 6 observa-se a evolução do Índice de Qualidade das Águas (IQA 20\%) nos Rios Cubatão, Mogi e Piaçaguera, no período de 1984 a 2005. Os dados de qualidade das águas foram obtidos nos relatórios de qualidade das águas interiores no Estado de São Paulo elaborados anualmente pela CETESB.

Quadro 6 - Índice de Qualidade das Águas nos Rios Cubatão, Mogi e PiaçagueraIQA $20 \%$

\begin{tabular}{|c|c|c|c|c|c|}
\hline \multirow[b]{3}{*}{ Ano } & $\begin{array}{l}\text { Ponto Amostragem } \\
\text { CUBA03900 }\end{array}$ & \multirow[b]{3}{*}{ Ano } & $\begin{array}{c}\text { Ponto Amostragem } \\
\text { MOGI02800 }\end{array}$ & \multirow[b]{3}{*}{ Ano } & $\begin{array}{l}\text { Ponto Amostragem } \\
\text { PIAC02700 }\end{array}$ \\
\hline & Rio Cubatão & & Rio Mogi & & Rio Piaçagüera \\
\hline & Índice IQA $20 \%$ & & Índice IQA $20 \%$ & & Índice IQA $20 \%$ \\
\hline 1984 & $\mathrm{BOA}$ & 1984 & RUIM & 1984 & PÉSSIMA \\
\hline 1985 & ACEITÁVEL & 1985 & RUIM & 1985 & PÉSSIMA \\
\hline 1986 & ACEITÁVEL & 1986 & RUIM & 1986 & PÉSSIMA \\
\hline 1987 & ACEITÁVEL & 1987 & ACEITÁVEL & 1987 & PÉSSIMA \\
\hline 1988 & ACEITÁVEL & 1988 & RUIM & 1988 & RUIM \\
\hline 1989 & ACEITÁVEL & 1989 & RUIM & 1989 & RUIM \\
\hline 1990 & RUIM & 1990 & RUIM & 1990 & PÉSSIMA \\
\hline 1991 & ACEITÁEL & 1991 & RUIM & 1991 & RUIM \\
\hline 1992 & RUIM & 1992 & RUIM & 1992 & RUIM \\
\hline 1993 & ACEITÁVEL & 1993 & RUIM & 1993 & RUIM \\
\hline
\end{tabular}




\begin{tabular}{|c|c|c|c|c|c|}
\hline 1994 & ACEITÁVEL & 1994 & RUIM & 1994 & RUIM \\
\hline 1995 & ACEITÁVEL & 1995 & ACEITÁVEL & 1995 & RUIM \\
\hline 1996 & ACEITÁVEL & 1996 & RUIM & 1996 & RUIM \\
\hline 1997 & ACEITÁVEL & 1997 & RUIM & 1997 & RUIM \\
\hline 1998 & ACEITÁVEL & 1998 & ACEITÁVEL & 1998 & RUIM \\
\hline 1999 & ACEITÁVEL & 1999 & RUIM & 1999 & ACEITÁVEL \\
\hline 2000 & BOA & 2000 & $\mathrm{BOA}$ & 2000 & RUIM \\
\hline 2001 & ACEITÁVEL & 2001 & ACEITÁVEL & 2001 & RUIM \\
\hline 2002 & $\mathrm{BOA}$ & 2002 & ACEITÁVEL & 2002 & ACEITÁVEL \\
\hline 2003 & ACEITÁVEL & 2003 & ACEITÁVEL & 2003 & ACEITÁVEL \\
\hline 2004 & $\mathrm{BOA}$ & 2004 & ACEITÁVEL & 2004 & ACEITÁVEL \\
\hline 2005 & BOA & 2005 & ACEITÁVEL & 2005 & ACEITÁVEL \\
\hline
\end{tabular}

Fonte: CETESB, 1984 a 2005.

O Índice de Qualidade das Águas (IQA) foi desenvolvido pela CETESB, a partir de um estudo realizado em 1970 pela National Sanitation Foundation dos Estado Unidos, e vem sendo utilizado para avaliar a qualidade das águas do Estado de São Paulo no que se refere à sua utilização para abastecimento público. O IQA é calculado pelo produtório ponderado das qualidades das águas correspondentes a 09 (nove) parâmetros considerados como relevantes para essa avaliação: temperatura da amostra, $\mathrm{pH}$, oxigênio dissolvido, demanda bioquímica de oxigênio ( 5 dias, $20^{\circ} \mathrm{C}$ ), coliforme fecal, nitrogênio total, fósforo total, resíduo total e turbidez.

A partir do cálculo efetuado, pode-se determinar a qualidade das águas brutas que, indicada pelo IQA, numa escala de 0 a 100, é classificada para abastecimento público, segundo a seguinte gradação:

- Qualidade Ótima

- Qualidade Boa

- Qualidade Regular

- Qualidade Ruim

- Qualidade Péssima

$$
\begin{aligned}
79<\mathrm{IQA} & \leq 100 \\
51<\mathrm{IQA} & \leq 79 \\
36<\mathrm{IQA} & \leq 51 \\
19<\mathrm{IQA} & \leq 36 \\
\mathrm{IQA} & \leq 19
\end{aligned}
$$

Considerando que o IQA é obtido mensalmente, com o intuito de representar a qualidade apresentada pelos corpos de águas monitorados, ao longo de um ano, definiu-se o IQA 20\%, cujo cálculo é feito a partir do ajuste de uma distribuição normal dos resultados do IQA obtidos para um determinado local ao longo de cada 
ano, e da obtenção do valor correspondente ao percentil 20\%. O valor do IQA 20\%, utilizado como indicador de qualidade das águas no presente trabalho, portanto, indica que durante $80 \%$ do tempo o ponto monitorado apresentou qualidade de água avaliada como igual ou superior a este valor (CETESB, 1999).

Verifica-se no Quadro 6 que dos três rios monitorados no município de Cubatão, o Rio Cubatão é aquele que apresenta melhores condições desde o início do programa, ao contrário dos Rios Mogi e Piaçaguera, cujas condições começaram a melhorar somente a partir do ano 2000 e 2002, respectivamente. Importante mencionar que nestes dois últimos rios não há captação de água para abastecimento público, mas somente no Rio Cubatão, ocorrendo a captação, porém, antes do ponto de amostragem considerado neste trabalho.

Em comparação com a evolução obtida no controle da poluição do ar, verifica-se que a melhoria da qualidade das águas demorou um pouco mais a ocorrer, em especial nos Rios Mogi e Piaçaguera, fato que pode ser imputado a uma menor preocupação com a qualidade das águas desses rios em razão de não serem utilizadas para abastecimento público. A ausência de informações sobre a carga poluidora das empresas, em razão do órgão ambiental não efetuar o inventário da carga poluidora dos cursos d'água por efluentes industriais, por empresa, não permite verificar qualquer associação entre esses fatores.

Da mesma forma que os indicadores relacionados à poluição do ar, o indicador utilizado para verificar a evolução da qualidade das águas, permite concluir que houve melhoria geral da qualidade das águas dos três principais cursos d'água do município. Essa melhoria, porém, além de ter demorado muito mais a ocorrer, se encontra muito aquém do ideal, visto que poucos foram os anos em que o índice de qualidade atingiu a classificação boa, nunca chegando à classificação ótima. Em um período de 22 anos, a condição boa foi atingida no ponto do Rio Cubatão utilizado na pesquisa somente em cinco anos e em um único ano no Rio Mogi, enquanto nunca foi atingida no Rio Piaçaguera.

Avaliando-se a evolução dos indicadores ambientais, nota-se que, embora tenha havido um grande avanço na melhoria das condições ambientais do município, ainda não está sendo garantida a sustentabilidade dos recursos naturais e a qualidade de vida exigidas pelo desenvolvimento sustentável, principalmente em razão das 
freqüentes ultrapassagens dos padrões de qualidade do ar, que demonstram a continuidade de efeitos nocivos à saúde pública e ao meio ambiente em Cubatão, embora em menores proporções que no início da década de 1980, somadas à pouca melhoria obtida na qualidade das águas.

No que se refere à avaliação da dimensão econômica do desenvolvimento sustentável, foi utilizado como indicador somente o PIB per capita, considerado suficiente para indicar a riqueza do município. Esse indicador representa o total dos bens e serviços produzidos pelas unidades produtoras, ou seja, a soma dos valores adicionados acrescida dos impostos, dividido pela população da respectiva agregação geográfica (FUNDAÇÃO SEADE, 2007b).

No Quadro 7 é apresentada a evolução do PIB per capita do município de Cubatão, no período de 1999 a 2004, para o qual existiam dados disponíveis.

Quadro 7 - Produto Interno Bruto (PIB) per capita do município de Cubatão.

\begin{tabular}{|c|c|c|c|c|c|}
\hline \multicolumn{7}{|c|}{ PIB per capita (em reais correntes) } \\
\hline 1999 & 2000 & 2001 & 2002 & 2003 & 2004 \\
\hline $23.838,84$ & $30.998,16$ & $34.700,06$ & $40.337,14$ & $61.899,19$ & $68.834,99$ \\
\hline
\end{tabular}

Fonte: FUNDAÇÃO SEADE, 2007b.

Observa-se no quadro acima que o PIB per capita do município vem aumentando gradativamente nesse período, atingindo, em 2004, quase o triplo daquele verificado em 1999, sendo mais de cinco vezes superior ao PIB per capita do Estado de São Paulo no mesmo ano, que foi de R\$ 13.725,14. Entretanto, face à ausência de dados para o período anterior a 1999, não foi possível efetuar a correlação entre a evolução desse indicador e a evolução dos indicadores ambientais. Embora os dados não sejam suficientes para estabelecer uma relação de causa-efeito entre a melhoria da qualidade ambiental do município, nos aspectos da poluição do ar e águas, e o aumento da riqueza gerada, os dados parecem indicar que essa relação pode ter ocorrido, merecendo ser avaliado em estudo específico o desempenho ambiental do pólo industrial de Cubatão, em termos de ecoeficiência econômica.

A evolução dos indicadores sociais e de condições de vida é apresentada abaixo.

Nos Quadros 8, 9 e 10 verifica-se o nível de atendimento da população do município pelos serviços públicos de abastecimento de água, coleta de lixo e esgoto 
sanitário, em porcentagem de domicílios particulares permanentes urbanos atendidos por rede geral de abastecimento de água, serviço regular de coleta de lixo e rede geral de esgoto sanitário, respectivamente. Os dados se referem somente aos anos de 1991 e 2000, para os quais existem dados secundários disponíveis, à exceção do esgoto sanitário, para o qual existem dados disponíveis também para os anos de 2001 a 2005.

Quadro 8 - Abastecimento de água - Nível de atendimento em Cubatão.

\begin{tabular}{|c|c|}
\hline \multicolumn{2}{|c|}{ Abastecimento de água - nível de atendimento (em \%) } \\
\hline 1991 & 2000 \\
\hline 91,13 & 85,07 \\
\hline
\end{tabular}

Fonte: FUNDAÇÃO SEADE, 2007b.

Quadro 9 - Coleta de lixo - Nível de atendimento em Cubatão.

\begin{tabular}{|c|c|}
\hline \multicolumn{2}{|c|}{ Coleta de lixo - nível de atendimento (em \%) } \\
\hline 1991 & 2000 \\
\hline 90,13 & 98,35 \\
\hline
\end{tabular}

Fonte: FUNDAÇÃO SEADE, 2007b.

Quadro 10 - Esgoto sanitário - Nível de atendimento em Cubatão

\begin{tabular}{|c|c|c|c|c|c|c|}
\hline \multicolumn{7}{|c|}{ Esgoto sanitário - nível de atendimento (em \%) } \\
\hline $1991 *$ & $2000 *$ & 2001 & 2002 & 2003 & 2004 & 2005 \\
\hline 18,69 & 44,37 & 25,00 & 30,00 & 31,00 & 31,00 & 35,00 \\
\hline
\end{tabular}

Fontes: FUNDAÇÃO SEADE, 2007b*, CETESB, 2001 a 2005.

Os indicadores sociais relacionados a saneamento básico, apresentados nos Quadros acima, demonstram que a população do município de Cubatão vem sendo atendida quase que em sua totalidade por rede geral de abastecimento de água e serviço regular de coleta de lixo, tendo havido, porém, queda no nível de atendimento por abastecimento de água de 1991 para 2000. As razões para essa redução não foram apuradas neste trabalho, por fugir aos seus objetivos. 
$\mathrm{O}$ atendimento por rede geral de esgoto sanitário, entretanto, ainda é bastante precário, alcançando somente $35 \%$ dos domicílios.

No início do Programa de Controle da Poluição Ambiental em Cubatão, em 1983, o município não dispunha de atendimento na coleta, tratamento e destino final de esgotos sanitários, prevalecendo o sistema unifamiliar. Um dos objetivos básicos do Programa era o de obter a redução das emissões de poluentes das águas, de modo a garantir o atendimento aos respectivos padrões legais de qualidade. Para tanto, conforme já citado no item 5.2.2., além do tratamento obrigatório dos efluentes industriais, previa-se a solução da poluição por efluentes de origem doméstica com a implantação de rede coletora de esgotos e estação de tratamento pela Companhia de Saneamento Básico do Estado de São Paulo (SABESP), prevista para ocorrer em dezembro/86, com capacidade para atender a uma população de 70.000 habitantes.

Nota-se, assim, que, quanto aos efluentes de origem doméstica, os objetivos do programa estão muito longe de serem atendidos. Esse fato pode ser decorrente do Programa ter dado maior ênfase no período objeto da pesquisa ao controle da poluição industrial, somado à existência de inúmeras áreas de invasão e favelas no município, várias delas situadas em áreas de preservação permanente e em unidades de conservação, com restrições para a instalação de equipamentos públicos. Conforme informações da Secretaria de Planejamento do município, em 2003 Cubatão contava com 28 (vinte e oito) áreas de invasão e favelas, que abrigavam 46.623 habitantes, representando aproximadamente $41,04 \%$ da população, estimada para o mesmo ano em 113.595 habitantes.

No Quadro 11 verifica-se a evolução da taxa de mortalidade infantil no município durante todo o período objeto da pesquisa, que significa a relação entre os óbitos de menores de um ano de residentes numa unidade geográfica, num determinado período de tempo (geralmente um ano) e os nascidos vivos da mesma unidade nesse período, segundo a fórmula:

Taxa de mortalidade infantil $=$ Óbitos de menores de 1 ano $\times 1000$ Nascidos vivos 
Quadro 11 - Taxa de mortalidade infantil em Cubatão

\begin{tabular}{|c|c|c|c|c|c|c|c|}
\hline 1983 & 1984 & 1985 & 1986 & 1987 & 1988 & 1989 & 1990 \\
\hline 53,52 & 45,47 & 36,66 & 31,49 & 34,88 & 38,76 & 42,31 & 33,27 \\
\hline & & & & & & & \\
\hline 1991 & 1992 & 1993 & 1994 & 1995 & 1996 & 1997 & 1998 \\
\hline 32,10 & 33,98 & 27,65 & 24,30 & 26,67 & 21,32 & 19,84 & 22,43 \\
\hline & & & & & & & \\
\hline 1999 & 2000 & 2001 & 2002 & 2003 & 2004 & 2005 & \\
\hline 18,75 & 22,54 & 17,40 & 23,21 & 19,16 & 19,98 & 17,72 & \\
\hline
\end{tabular}

Fonte: FUNDAÇÃO SEADE, 2007b.

Os dados desse quadro demonstram que tem havido redução gradativa da mortalidade infantil no município de Cubatão, do início do programa até o ano de 2005.

Nos quadros 12 e 13 podem ser observadas informações sobre o nível de escolaridade da população de Cubatão para o ano 2000, ou seja, o número médio de anos de estudo da população na faixa etária indicada e o percentual da população de 25 anos e mais com menos de 8 anos de estudo em relação à população total da mesma faixa etária, respectivamente, e as mesmas informações para o total do Estado de São Paulo, com a finalidade de possibilitar alguma comparação, já que não foi possível verificar a evolução da escolaridade, face à ausência de dados disponíveis para os demais anos.

Quadro 12 - Média de Anos de Estudos da População de 15 a 64 Anos

\begin{tabular}{|c|c|}
\hline Cubatão & Estado de São Paulo \\
\hline 2000 & 2000 \\
\hline 6,84 & 7,64 \\
\hline
\end{tabular}

Fonte: FUNDAÇÃO SEADE, 2007b.

Quadro 13 - População de 25 anos e mais com menos de 8 anos de estudo ( em \%)

\begin{tabular}{|c|c|}
\hline Cubatão & Estado de São Paulo \\
\hline 2000 & 2000 \\
\hline
\end{tabular}




\begin{tabular}{|c|c|}
\hline 60,73 & 55,55 \\
\hline
\end{tabular}

Fonte: FUNDAÇÃO SEADE, 2007b.

Os dados dos quadros 12 e 13 demonstram que o nível de escolaridade do município de Cubatão está abaixo da média do total do Estado.

No Quadro 14 é possível verificar a evolução do IDHM - Índice de Desenvolvimento Humano Municipal do município de Cubatão. O IDHM trata-se de um "indicador que focaliza o município como unidade de análise, a partir das dimensões de longevidade, educação e renda, que participam com pesos iguais na sua determinação" (FUNDAÇÃO SEADE, 2007b), segundo a fórmula:

IDHM = Índice de longevidade+Índice de educação+Índice de renda 3

Para referência, segundo classificação do Programa das Nações Unidas para o Desenvolvimento Humano (PNUD), os valores distribuem-se em três categorias:

a) Baixo desenvolvimento humano, quando o IDHM for menor que 0,500;

b) Médio desenvolvimento humano, para valores entre 0,500 e 0,800;

c) Alto desenvolvimento humano, quando o índice for superior a 0,800.

Quadro 14 - IDH- Índice de Desenvolvimento Humano do Município de Cubatão

\begin{tabular}{|c|c|c|}
\hline \multicolumn{3}{|c|}{ IDH - Índice de Desenvolvimento Humano } \\
\hline 1980 & 1991 & 2000 \\
\hline 0,705 & 0,723 & 0,772 \\
\hline
\end{tabular}

Fonte: FUNDAÇÃO SEADE, 2007b.

Os anos para os quais existiam informações disponíveis, 1980 (antes do início do Programa de Controle da Poluição Ambiental em Cubatão), 1991 e 2000 (nove 
anos e 18 anos depois, respectivamente), permitem notar que não houve grande alteração do IDH do município de Cubatão no período da pesquisa, que permanece apresentando médio desenvolvimento humano, com pequena melhoria de 1980 para 2000 .

No Quadro 15 observa-se o IPRS-Índice Paulista de Responsabilidade Social do município de Cubatão para os anos 2000, 2002 e 2004, e o IPVS-Índice Paulista de Vulnerabilidade Social calculado para o ano 2000. Os indicadores do IPRS sintetizam a situação de cada município no que diz respeito a riqueza, escolaridade e longevidade. O IPVS permite identificar nos municípios do Estado de São Paulo, particularmente naqueles de maior porte, áreas em que predominam famílias expostas a diferentes níveis de vulnerabilidade social, adotando como unidade de análise os setores censitários utilizados pelo IBGE na realização do Censo Demográfico. O IPVS, conforme exposto no item 2.3.5. deste trabalho, baseia-se em uma tipologia derivada da combinação entre os indicadores sintéticos das dimensões socioeconômica e demográfica, permitindo classificar os setores censitários em seis categorias, segundo o grau de vulnerabilidade social da população neles residente: nenhuma vulnerabilidade, vulnerabilidade muito baixa, vulnerabilidade baixa, vulnerabilidade média, vulnerabilidade alta e vulnerabilidade muito alta.

Quadro 15 - Índice Paulista de Responsabilidade Social e Índice Paulista de Vulnerabilidade Social do Município de Cubatão.

\begin{tabular}{|c|c|c|c|}
\hline & 2000 & 2002 & 2004 \\
\hline $\begin{array}{l}\text { Condições de Vida- Índice } \\
\text { Paulista de } \\
\text { Responsabilidade Social - } \\
\text { IPRS }\end{array}$ & $\begin{array}{r}\text { Grupo 2- } \\
\text { Municípios que, } \\
\text { embora com níveis } \\
\text { de riqueza elevados, } \\
\text { não exibem bons } \\
\text { indicadores sociais }\end{array}$ & $\begin{array}{r}\text { Grupo 2- } \\
\text { Municípios que, } \\
\text { embora com níveis } \\
\text { de riqueza elevados, } \\
\text { não exibem bons } \\
\text { indicadores sociais }\end{array}$ & $\begin{array}{r}\text { Grupo 2- } \\
\text { Municípios que, } \\
\text { embora com níveis } \\
\text { de riqueza elevados, } \\
\text { não exibem bons } \\
\text { indicadores sociais }\end{array}$ \\
\hline $\begin{array}{l}\text { Condições de Vida - IPVS } \\
\text { - Grupo } 1 \text { - Nenhuma }\end{array}$ & 0,37 & 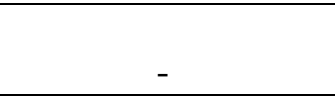 & 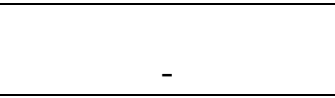 \\
\hline
\end{tabular}




\begin{tabular}{|c|c|c|c|}
\hline $\begin{array}{l}\text { Vulnerabilidade (\% da } \\
\text { população exposta) }\end{array}$ & & & \\
\hline $\begin{array}{l}\text { Condições de Vida - IPVS } \\
\text { - Grupo } 2 \text { - } \\
\text { Vulnerabilidade Muito } \\
\text { Baixa (\% da população } \\
\text { exposta) }\end{array}$ & 16,10 & - & - \\
\hline \begin{tabular}{l}
\multicolumn{4}{l}{ Condições de Vida - IPVS } \\
$-\quad$ Grupo 3 \\
Vulnerabilidade Baixa \\
da população exposta)
\end{tabular} & 23,34 & - & - \\
\hline $\begin{array}{l}\text { Condições de Vida - IPVS } \\
- \text { Grupo } 4-\text { Média } \\
\text { Vulnerabilidade }(\% \text { da } \\
\text { população exposta })\end{array}$ & 17,97 & - & - \\
\hline 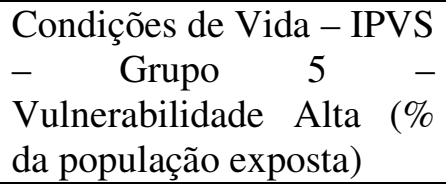 & 21,19 & - & - \\
\hline \begin{tabular}{l}
\multicolumn{3}{c}{ Condições de Vida - IPVS } \\
$-\quad$ Grupo 6 \\
Vulnerabilidade \\
Alta (\% da população \\
exposta)
\end{tabular} & 21,04 & - & - \\
\hline
\end{tabular}

Fonte: FUNDAÇÃO SEADE, 2007b.

Analisando a evolução dos indicadores sociais e de condições de vida selecionados na pesquisa, verifica-se que enquanto a evolução da riqueza do município de Cubatão parece ter acompanhado a melhoria da qualidade ambiental alcançada a partir do início do Programa de Controle da Poluição, em 1983, até 2005, o mesmo não ocorreu com as condições de vida da população, que continua apresentando baixo nível de escolaridade, condições precárias de saneamento básico, com atendimento de apenas 35\% dos domicílios por rede geral de esgoto sanitário, vivendo mais de $40 \%$ da população em favelas. O IPRS resume bem a situação do município nesse aspecto, verificando-se, ainda, pelo IPVS, que mais de $40 \%$ da população vive em condições de vulnerabilidade alta ou muito alta.

Esse resultado, além de confirmar, desde logo, a insuficiência do PIB per capita como indicador de desenvolvimento sustentável, conforme mencionado no 
item 2.3.4., por não ser capaz de capturar todos os aspectos importantes deste, demonstra que o desenvolvimento do município, de fato, não vem sendo efetuado em bases sustentáveis, face à ausência de harmonia entre as dimensões econômica, ambiental e social.

No que se refere aos indicadores institucionais, no Quadro 16 pode-se verificar o percentual de despesas com gestão ambiental no total do orçamento do município de Cubatão. O quadro foi elaborado a partir de dados secundários oriundos da Fundação SEADE, bem como dados obtidos junto à Secretaria de Planejamento do município de Cubatão, abrangendo os anos para os quais existem dados disponíveis. O cálculo foi efetuado com base na previsão orçamentária e não nos valores efetivamente realizados em cada um dos exercícios. Não foram considerados nos valores destinados à gestão ambiental os gastos com pessoal.

Quadro 16 - Percentual das Despesas com Gestão Ambiental no Total do Orçamento do Município de Cubatão.

\begin{tabular}{|c|c|c|c|c|c|c|c|c|}
\hline 1995 & 1997 & 1998 & 1999 & 2001 & 2002 & 2003 & 2004 & 2005 \\
\hline 5,88 & 8,33 & 10,45 & 6,30 & 3,31 & 2,33 & 2,22 & 1,74 & 2,63 \\
\hline
\end{tabular}

Fontes: FUNDAÇÃO SEADE, 2007b, Secretaria de Planejamento de Cubatão, 2007.

Analisando o Quadro acima nota-se que o município vem reduzindo o percentual do orçamento destinado a despesas com gestão ambiental, especialmente a partir do ano 2001, podendo-se verificar, a despeito da ausência de informações mais detalhadas, que os investimentos municipais nesse aspecto não são significativos, principalmente se levarmos em consideração os diversos problemas ambientais do município. A existência de Conselho Municipal de Meio Ambiente criado, porém não implementado, somada à inexistência de leis municipais específicas para proteção ou controle ambiental (FUNDAÇÃO SEADE, 2007b), contribuem para demonstrar a insuficiência de investimentos municipais na gestão ambiental e a pouca importância dada a esse aspecto pelo município. 
Outro aspecto avaliado refere-se à existência de instrumentos processuais adequados às ações relativas às causas ambientais.

No Quadro 17 verifica-se o número de ações civis públicas propostas e termos de compromisso e ajustamento de conduta formalizados pelo Ministério Público no período da pesquisa, o qual foi elaborado a partir de dados obtidos junto à Promotoria de Justiça de Cubatão. Na avaliação dos dados foi considerado que a Lei de Ação Civil Pública foi editada em 24 de julho de 1985 (Lei 7.347/85), bem como que a possibilidade dos órgãos públicos legitimados tomarem dos interessados compromisso de ajustamento de sua conduta às exigências legais passou a existir somente a partir da edição do Código de Defesa do Consumidor em 11 de setembro de 1990 (Lei 8.078/90), que acrescentou o $§ 6^{\circ}$ ao art. $5^{\circ}$, da Lei 7.347/85.

Quadro 17 - Ações Civis Públicas (ACPs) Propostas e Termos de Compromisso de Ajustamento de Conduta (TACs) Formalizados pelo Ministério Público.

\begin{tabular}{|c|c|c|c|c|c|}
\cline { 2 - 6 } \multicolumn{1}{c|}{} & 1986 & 1987 & 1988 & 1989 & 1990 \\
\hline ACPs & 03 & - & - & - & 01 \\
\hline TACs & - & - & - & - & - \\
\cline { 2 - 6 } \multicolumn{1}{c|}{} & 1991 & 1992 & 1993 & 1994 & 1995 \\
\hline ACPs & 04 & 04 & 03 & 02 & - \\
\hline TACs & - & - & - & 01 & 01 \\
\cline { 2 - 6 } \multicolumn{1}{c|}{} & 1996 & 1997 & 1998 & 1999 & 2000 \\
\hline ACPs & 02 & 03 & 01 & 04 & 02 \\
\hline TACs & - & - & 01 & 01 & 03 \\
\hline & & & & & \\
\cline { 2 - 6 } \multicolumn{1}{c|}{} & 2001 & 2002 & 2003 & 2004 & 2005 \\
\hline ACPs & 02 & 03 & - & 02 & 02 \\
\hline TACs & 07 & 13 & 04 & 09 & 05 \\
\hline
\end{tabular}

Fonte: Ministério Público de São Paulo, 2007.

Nota-se que, enquanto o número de ações civis públicas propostas pelo Ministério Público de São Paulo em Cubatão não se alterou muito ao longo de todo o período da pesquisa, o mesmo não ocorreu com o instrumento do Termo de Compromisso de Ajustamento de Conduta, cuja utilização na solução dos conflitos 
ambientais aumentou consideravelmente a partir do ano 2000. Conforme informações obtidas junto à Promotoria de Justiça de Cubatão, algumas das ações civis públicas em andamento foram, inclusive, solucionadas por TACs. Foi obtida, ainda, a informação de que a partir do ano 2002 foram formalizados seis TACs com a participação da CETESB, bem como que quatro deles se referem à regularização ambiental de fontes autuadas em 1984.

Esse resultado demonstra que, a despeito da ação civil pública ser importante instrumento na tutela do meio ambiente, o surgimento do Termo de Compromisso de Ajustamento de Conduta facilitou essa tutela pelo Poder Público, sendo mais adequado à solução consensual dos conflitos ambientais, que vem aumentando como consequência da conscientização ambiental da sociedade como um todo. Por esse motivo, há necessidade de que os instrumentos legais postos à disposição da sociedade para a tutela do meio ambiente acompanhem a evolução dessa mesma sociedade na direção do desenvolvimento sustentável.

\subsection{AVALIAÇÃO DAS INFORMAÇÕES DISPONÍVEIS SOBRE CUBATÃO E A NECESSIDADE DE NOVOS INDICADORES PARA O MUNICÍPIO}

Na realização deste trabalho, conforme já mencionado no item 5.3, verificouse que as informações oficiais disponíveis à sociedade para a avaliação da evolução do Programa de Controle da Poluição Ambiental em Cubatão e da situação do município, quanto ao controle da poluição do ar e das águas, ou seja, os relatórios de qualidade do ar e de qualidade das águas interiores elaborados anualmente pela CETESB, apresentam algumas falhas e imperfeições.

Assim, por exemplo, o inventário das emissões de poluentes do ar não é feito anualmente, conforme esclarecimentos obtidos junto ao órgão ambiental, aspecto que torna as informações inconsistentes, dificultando a correta avaliação da evolução do Programa, bem como dos instrumentos empregados na gestão ambiental do município. O inventário da carga poluidora dos cursos d'água por efluentes industriais, por empresa, por seu turno, nunca foi efetuado, impossibilitando a avaliação da contribuição individual das indústrias para a qualidade dos cursos d'água do município. 
O órgão ambiental, ainda, não possui informações sistematizadas sobre a evolução da geração e destinação final adequadas para os resíduos sólidos industriais gerados em Cubatão, impossibilitando a verificação da adoção de práticas ambientais mais adequadas pelas indústrias, baseadas na redução da geração, reaproveitamento e reciclagem.

Outro aspecto reconhecidamente importante no município diz respeito à contaminação do solo e de sedimentos. Embora o problema já seja conhecido há vários anos e a CETESB tenha implantado cadastro de áreas contaminadas do Estado de São Paulo em data recente (2002), faltam informações que permitam avaliar a gestão ambiental desenvolvida para esse setor.

Também houve dificuldades para encontrar informações sobre a degradação da vegetação no município, motivo pelo qual não foram utilizados na pesquisa indicadores ambientais referentes a esse aspecto. Foi localizado trabalho recente realizado pelo Instituto Florestal, denominado "Inventário Florestal da Vegetação Natural do Estado de São Paulo" (KRONKA et. al., 2005), que apresenta a distribuição espacial e respectiva quantificação da vegetação natural, devidamente identificadas de acordo com suas diferentes fitofisionomias, considerando dois enfoques: Regiões Administrativas e Unidades de Gerenciamento dos Recursos Hídricos (Bacias Hidrográficas). No trabalho, que se refere aos anos de 2000-2001, foram consideradas, ainda, informações de levantamentos anteriores, alguns deles parciais, em especial inventário realizado pelo próprio Instituto referente aos anos de 1990-92. Segundo os autores, esse trabalho permitiu a estruturação de base georreferenciada para fins de monitoramento, que possibilitará "o mapeamento e avaliação periódica de uma mesma área em intervalos de tempo regulares para estudos e controle da dinâmica das mudanças" (p. 20).

As informações existentes sobre os aspectos sociais e econômicos, por seu turno, limitam-se a poucos anos, ficando à mercê principalmente de ações do governo federal, por meio dos censos realizados com longos períodos de intervalo, enquanto a ausência de informações na forma de indicadores institucionais é praticamente absoluta. 
O município de Cubatão, por sua vez, não produz informações sistematizadas, na forma de indicadores, sobre quaisquer dos temas considerados relevantes na promoção do desenvolvimento sustentável.

As dificuldades encontradas na pesquisa para a seleção dos indicadores de desenvolvimento sustentável que seriam utilizados, tanto no que se refere a ausência de informações sistematizadas sobre diversos aspectos, quanto à inadequação de algumas informações disponíveis à sociedade, demonstram, portanto, a insuficiência do sistema de informações existente para a correta avaliação do progresso do município nessa direção.

Verificou-se, antes da proposição de novos indicadores, a necessidade de que indicadores já consolidados como necessários à avaliação do progresso na direção do desenvolvimento sustentável, tais como indicadores sociais sobre educação, saúde e saneamento, sejam produzidos em intervalos de tempo que possibilitem o monitoramento e avaliação da implantação das políticas e ações necessárias, orientando o planejamento e o processo de tomada de decisões, permitindo a intervenção adequada, no tempo adequado, e, ainda, possibilitando à população acompanhar e participar desse processo.

O ideal seria que essas informações fossem produzidas e sistematizadas pelo próprio município, face à maior familiaridade com as características, problemas e necessidades deste, na forma de indicadores capazes de espelhar a situação atual e acompanhar a evolução desta ao longo dos anos.

Importante mencionar que o Estado de São Paulo possui um órgão capacitado para a produção de indicadores, que é a Fundação SEADE (Fundação Sistema Estadual de Análise de Dados), a qual atua na produção e disseminação de pesquisas, análises e estatísticas socioeconômicas e demográficas, oferecendo à comunidade e aos agentes públicos informações indispensáveis à compreensão da realidade paulista, inclusive de cada um dos municípios do Estado. Essa fundação, desde que tivesse a infra-estrutura adequada, poderia ser incumbida da produção desses dados.

No processo de produção de indicadores sobre o município de Cubatão, torna-se necessário considerar suas características e problemas específicos. Sem a pretensão de esgotar o tema, especialmente considerando-se que os sistemas de indicadores devem ser flexíveis, permitindo as necessárias adaptações, num processo 
de melhoria contínua, foi verificada a ausência de informações sistematizadas na forma de indicadores sobre alguns importantes aspectos do município, tais como indicadores que possibilitem verificar a real situação do meio ambiente em relação aos resíduos industriais, à contaminação de áreas e à vegetação, assim como sobre a adoção de práticas e ações ambientalmente sustentáveis pelo município e pelas indústrias. $\mathrm{O}$ mesmo ocorreu quanto a aspectos sociais, como informações a respeito do crescimento das favelas, especialmente em áreas protegidas, e o percentual da população vivendo nessas áreas, que representa um grave problema do município. A relação falta de saneamento-saúde, a taxa de desemprego e sua relação com a escolaridade, assim como indicadores institucionais que demonstrem a preocupação com a proteção do meio ambiente e o desenvolvimento sustentável foram outros importantes aspectos sobre os quais não foram encontrados indicadores adequados.

Com base nos resultados da pesquisa, no Quadro 18 são propostos alguns indicadores considerados relevantes para o município.

Quadro 18 - Proposta de Indicadores de Desenvolvimento Sustentável para Cubatão

\begin{tabular}{|c|c|c|}
\hline INDICADOR & JUSTIFICATIVA & UTILIZAÇÃO \\
\hline $\begin{array}{l}\text { - Geração de resíduos } \\
\text { sólidos industriais em } \\
\text { tonelada/ano }\end{array}$ & \multirow{3}{*}{$\begin{array}{l}\text { Permite verificar se o setor industrial efetua o } \\
\text { gerenciamento sustentável de resíduos sólidos, no qual a } \\
\text { redução da geração, a reutilização e a reciclagem são } \\
\text { atividades fundamentais. Por representarem maiores } \\
\text { riscos à saúde pública e ao meio ambiente, os resíduos } \\
\text { perigosos são um dos mais preocupantes, justificando a } \\
\text { verificação do percentual desse tipo de resíduos sobre o } \\
\text { total gerado. Pode subsidiar a elaboração de políticas } \\
\text { públicas visando à adoção de práticas ambientalmente } \\
\text { sustentáveis pelas indústrias na gestão dos resíduos } \\
\text { sólidos. }\end{array}$} & IBGE \\
\hline $\begin{array}{l}\text { - \% de resíduos industriais } \\
\text { perigosos sobre o total } \\
\text { gerado }\end{array}$ & & CDS \\
\hline $\begin{array}{l}\text { - \% dos resíduos industriais } \\
\text { destinados à reciclagem/ } \\
\text { reaproveitamento sobre o } \\
\text { total gerado }\end{array}$ & & Seattle (EUA) \\
\hline $\begin{array}{l}\text { - \% da área contaminada } \\
\text { sobre o total da área do } \\
\text { município }\end{array}$ & $\begin{array}{l}\text { Na região da Baixada Santista, Cubatão é um dos } \\
\text { municípios que apresenta maior número de áreas } \\
\text { contaminadas identificadas e cadastradas na CETESB. } \\
\text { Permite verificar a extensão das áreas contaminadas, } \\
\text { que acarretam danos ao meio ambiente e à saúde } \\
\text { pública, bem como daquelas recuperadas, possibilitando } \\
\text { a avaliação e o aperfeiçoamento da gestão desenvolvida } \\
\text { para esse setor. }\end{array}$ & \\
\hline
\end{tabular}


Quadro 18 - Proposta de Indicadores de Desenvolvimento Sustentável para Cubatão (cont.)

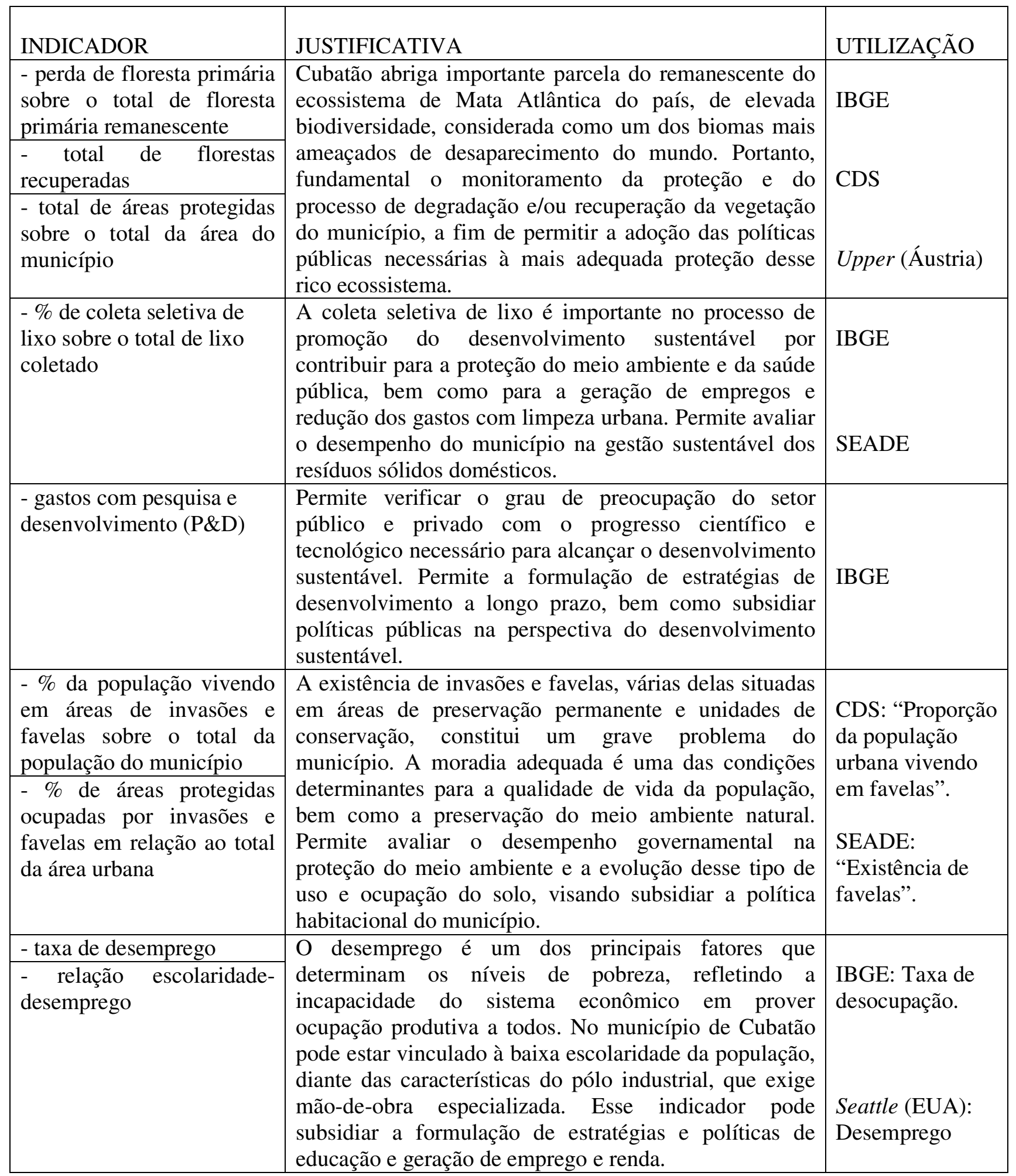


Quadro 18 - Proposta de Indicadores de Desenvolvimento Sustentável para Cubatão (cont.)

\begin{tabular}{|c|c|c|}
\hline INDICADOR & JUSTIFICATIVA & UTILIZAÇÃO \\
\hline $\begin{array}{l}\text { - incidência de doenças } \\
\text { relacionadas ao } \\
\text { saneamento ambiental } \\
\text { inadequado }\end{array}$ & $\begin{array}{l}\text { O saneamento ambiental de Cubatão é precário, } \\
\text { especialmente no que concerne ao esgotamento } \\
\text { sanitário. Ampliar o acesso ao saneamento básico } \\
\text { (abastecimento de água, esgotamento sanitário, coleta e } \\
\text { destino final dos resíduos sólidos, drenagem urbana) é } \\
\text { fundamental para melhorar a qualidade de vida da } \\
\text { população e reduzir a pobreza, sendo um dos objetivos } \\
\text { essenciais do desenvolvimento sustentável. O indicador } \\
\text { permite conhecer, monitorar e avaliar a situação de } \\
\text { saúde relacionada às condições de saneamento } \\
\text { ambiental e subsidiar ações nesta área. }\end{array}$ & IBGE \\
\hline $\begin{array}{l}\text { - \% do gasto público com } \\
\text { proteção do meio ambiente } \\
\text { no total do orçamento do } \\
\text { município }\end{array}$ & \multirow{2}{*}{$\begin{array}{l}\text { Verifica a capacidade de atuação e o grau de } \\
\text { comprometimento do município na proteção do meio } \\
\text { ambiente, que é uma das atribuições do Poder Público, } \\
\text { trazendo subsídios para avaliar o desempenho } \\
\text { governamental e orientar os gastos públicos. }\end{array}$} & \multirow{2}{*}{$\begin{array}{l}\text { IBGE } \\
\text { (o primeiro) } \\
\text { SEADE (ambos) }\end{array}$} \\
\hline $\begin{array}{l}\text { - existência de leis } \\
\text { municipais específicas para } \\
\text { proteção do meio ambiente }\end{array}$ & & \\
\hline $\begin{array}{l}\text { - existência de Conselho } \\
\text { Municipal do Meio } \\
\text { Ambiente em atividade }\end{array}$ & $\begin{array}{l}\text { Os Conselhos constituem importante mecanismo de } \\
\text { consulta e exercício da participação popular na gestão } \\
\text { pública, sendo sua institucionalização uma forma de } \\
\text { capacitação para a gestão local. Revela o nível de } \\
\text { organização municipal no que se refere à } \\
\text { democratização da gestão de políticas públicas } \\
\text { ambientais para a solução de problemas locais. }\end{array}$ & IBGE \\
\hline
\end{tabular}

\subsection{OS PRINCIPAIS FATORES DETERMINANTES DA EVOLUÇÃO DO CONTROLE DA POLUIÇÃO EM CUBATÃO, SEGUNDO OS ATORES ENVOLVIDOS}

A Tabela 17 contém todos os fatores considerados na pesquisa como os principais determinantes da evolução do controle da poluição em Cubatão, com as respectivas freqüências de escolha dos participantes, assim como a sua nulidade. $\mathrm{Na}$ Tabela 18 pode-se observar outros fatores apontados, além daqueles previamente considerados. 
Tabela 17 - Freqüência dos fatores da evolução do controle da poluição em Cubatão.

\begin{tabular}{|c|c|c|}
\hline Exigência de mercado local & $\begin{array}{l}\text { Freqüência } \\
\text { Branco }\end{array}$ & $\begin{array}{c}3 \\
39 \\
\end{array}$ \\
\hline Pressão da mídia & $\begin{array}{l}\text { Freqüência } \\
\text { Branco }\end{array}$ & $\begin{array}{l}26 \\
16\end{array}$ \\
\hline Promulgação da Constituição Federal de 1988 & $\begin{array}{l}\text { Freqüência } \\
\text { Branco }\end{array}$ & $\begin{array}{c}5 \\
37 \\
\end{array}$ \\
\hline Atuação do Poder Executivo do Município & $\begin{array}{l}\text { Freqüêêcia } \\
\text { Branco }\end{array}$ & $\begin{array}{c}4 \\
38 \\
\end{array}$ \\
\hline Autuações da CETESB & $\begin{array}{l}\text { Freqüência } \\
\text { Branco }\end{array}$ & $\begin{array}{l}21 \\
21\end{array}$ \\
\hline Pressão da comunidade científica & $\begin{array}{l}\text { Freqüência } \\
\text { Branco }\end{array}$ & $\begin{array}{l}12 \\
30\end{array}$ \\
\hline Ações Civis Públicas movidas pelo Ministério Público & $\begin{array}{l}\text { Freqüência } \\
\text { Branco }\end{array}$ & $\begin{array}{l}17 \\
25\end{array}$ \\
\hline Atuação de ONGs & $\begin{array}{l}\text { Freqüência } \\
\text { Branco }\end{array}$ & $\begin{array}{c}5 \\
37 \\
\end{array}$ \\
\hline Edição da Lei dos Crimes Ambientais & $\begin{array}{l}\text { Freqüência } \\
\text { Branco }\end{array}$ & $\begin{array}{l}13 \\
29\end{array}$ \\
\hline Conscientização ambiental dos dirigentes das Indústrias & $\begin{array}{l}\text { Freqüêência } \\
\text { Branco }\end{array}$ & $\begin{array}{l}19 \\
23\end{array}$ \\
\hline Orientação e apoio Técnico da CETESB & $\begin{array}{l}\text { Freqüência } \\
\text { Branco }\end{array}$ & $\begin{array}{l}10 \\
32\end{array}$ \\
\hline $\begin{array}{l}\text { Termos de ajustamento de conduta formulados com o } \\
\text { Ministério Público }\end{array}$ & $\begin{array}{l}\text { Freqüiência } \\
\text { Branco }\end{array}$ & $\begin{array}{l}13 \\
29\end{array}$ \\
\hline Avanço dos conhecimentos científico/tecnológico & $\begin{array}{l}\text { Freqüência } \\
\text { Branco }\end{array}$ & $\begin{array}{l}11 \\
31\end{array}$ \\
\hline Exigência de mercado internacional & $\begin{array}{c}\text { Freqüêência } \\
\text { Branco }\end{array}$ & $\begin{array}{c}6 \\
36 \\
\end{array}$ \\
\hline Atuação do Poder Legislativo do Município & $\begin{array}{l}\text { Frequiência } \\
\text { Branco }\end{array}$ & $\begin{array}{c}4 \\
38 \\
\end{array}$ \\
\hline Pressão da comunidade do Município & $\begin{array}{l}\text { Freqüência } \\
\text { Branco }\end{array}$ & $\begin{array}{l}17 \\
25\end{array}$ \\
\hline Edição da Lei de Ação Civil Pública & $\begin{array}{c}\text { Freqüêência } \\
\text { Branco }\end{array}$ & $\begin{array}{c}8 \\
34 \\
\end{array}$ \\
\hline Atuação do CONSEMA & $\begin{array}{l}\text { Freqüência } \\
\text { Branco }\end{array}$ & $\begin{array}{c}0 \\
42 \\
\end{array}$ \\
\hline Decisões do Poder Judiciário & $\begin{array}{l}\text { Freqüência } \\
\text { Branco }\end{array}$ & $\begin{array}{c}2 \\
40\end{array}$ \\
\hline Exigências da Matriz Internacional & Freqüêencia & 3 \\
\hline
\end{tabular}


Tabela 18 - Freqüência de outros fatores apontados para a evolução do controle da poluição em Cubatão.

\begin{tabular}{lcc}
\hline Outros fatores: influência política & Freqüência & 1 \\
& Branco & 41 \\
\hline Outros fatores: o programa da CETESB & Freqüência & 1 \\
& Branco & 41 \\
\hline Outros fatores: Lei Estadual & Freqüência & 1 \\
& Branco & 41 \\
\hline Outros fatores: Episódios & Freqüência & 1 \\
& Branco & 41 \\
\hline Outros fatores: investimentos Ambientais & Freqüência & 1 \\
& Branco & 41 \\
\hline Outros fatores: política nacional & Freqüência & 1 \\
& Branco & 41 \\
\hline Outros fatores: Poder Executivo Estadual & Freqüência & 1 \\
& Branco & 41 \\
\hline
\end{tabular}

Considerando que a questão solicitou dos participantes a escolha de apenas 05(cinco) dentre as alternativas estabelecidas, com a graduação dos fatores escolhidos, numerando-os em ordem de importância, foram elaborados gráficos de distribuição de frequiência, por ordem de importância, com base nos 05(cinco) fatores genericamente mais votados - Pressão da mídia, Autuações da CETESB, Conscientização ambiental dos dirigentes das indústrias, Ações Civis Públicas movidas pelo Ministério Público e Pressão da Comunidade do Município de Cubatão - os quais permitem visualizar o destaque dado pelos participantes a esses fatores. 
Figura 3 - Distribuição de Freqüência da Pressão da mídia por ordem de importância

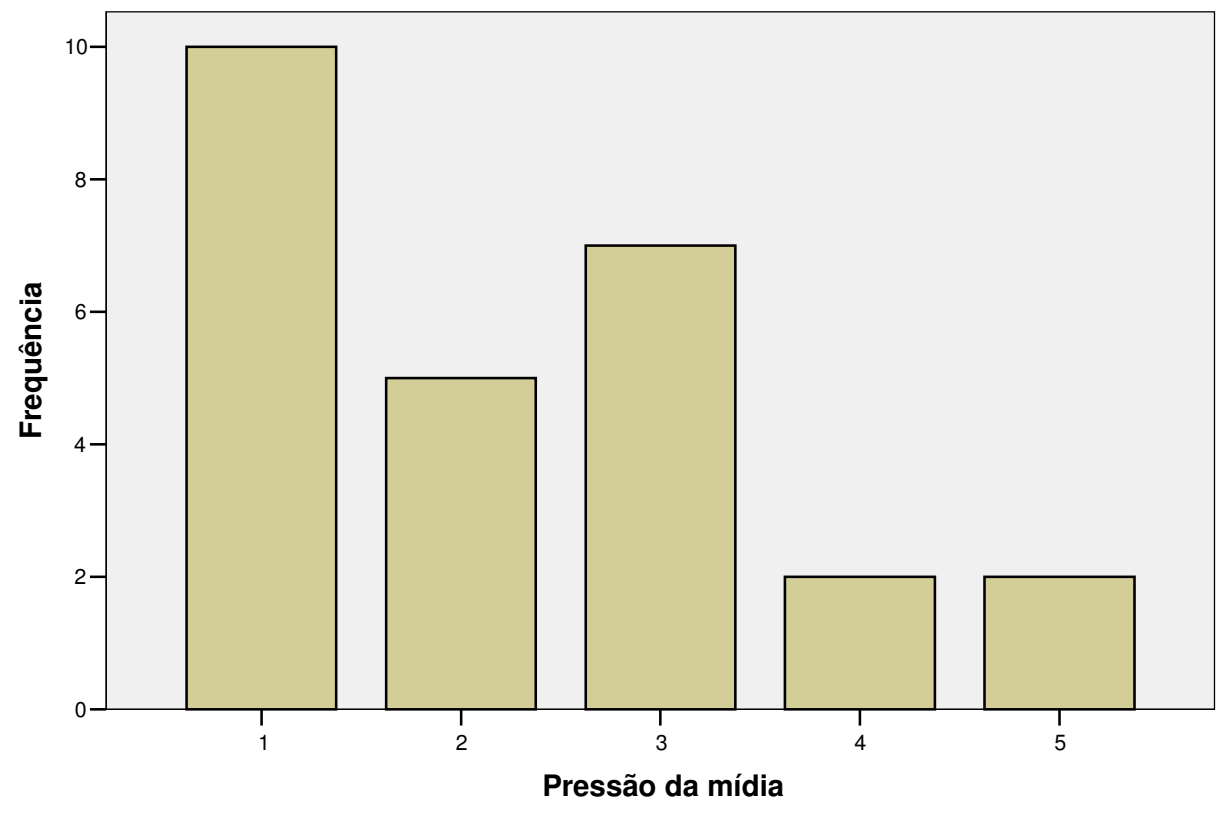


Figura 4 - Distribuição de Freqüência das Autuações da CETESB por ordem de importância

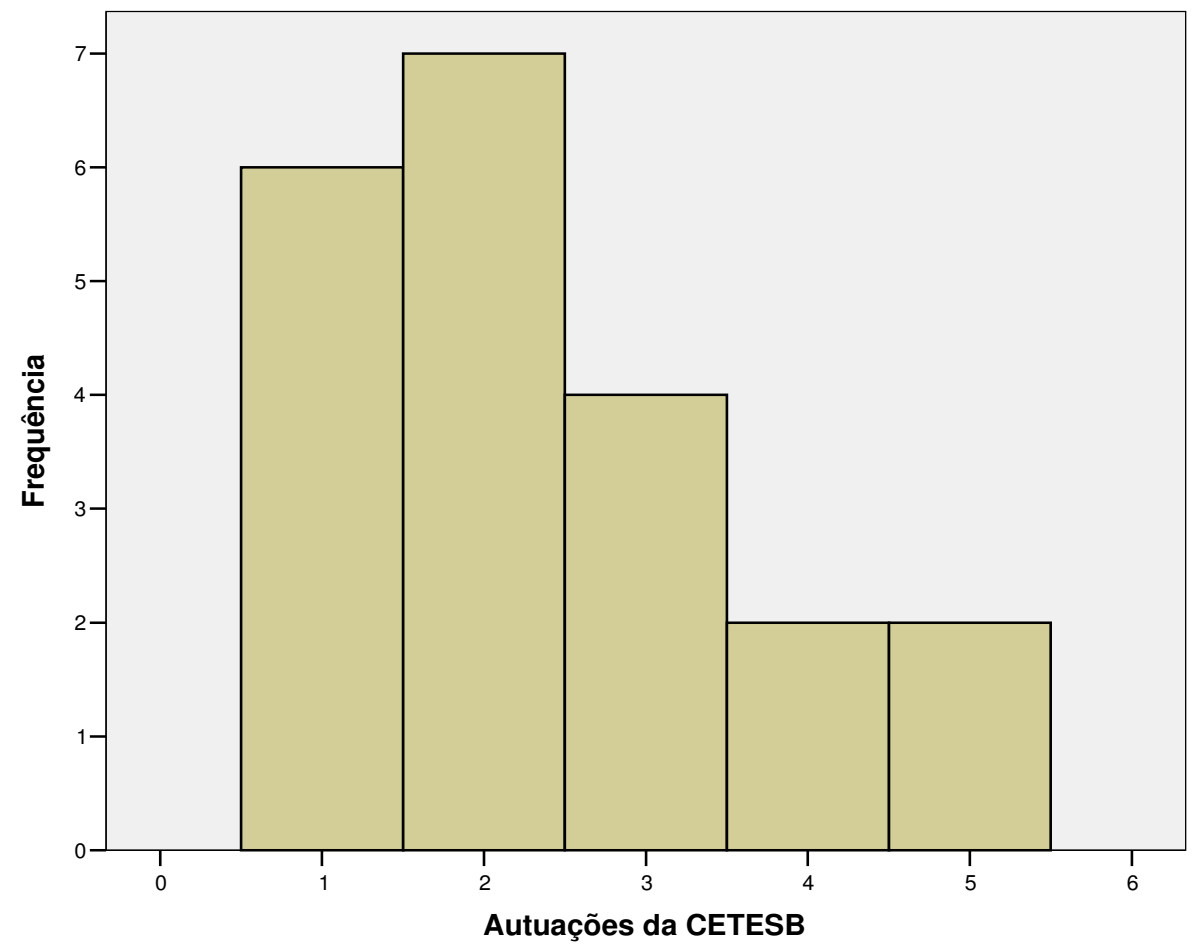


Figura 5 - Distribuição de Frequência da Conscientização ambiental dos dirigentes das Indústrias por ordem de importância

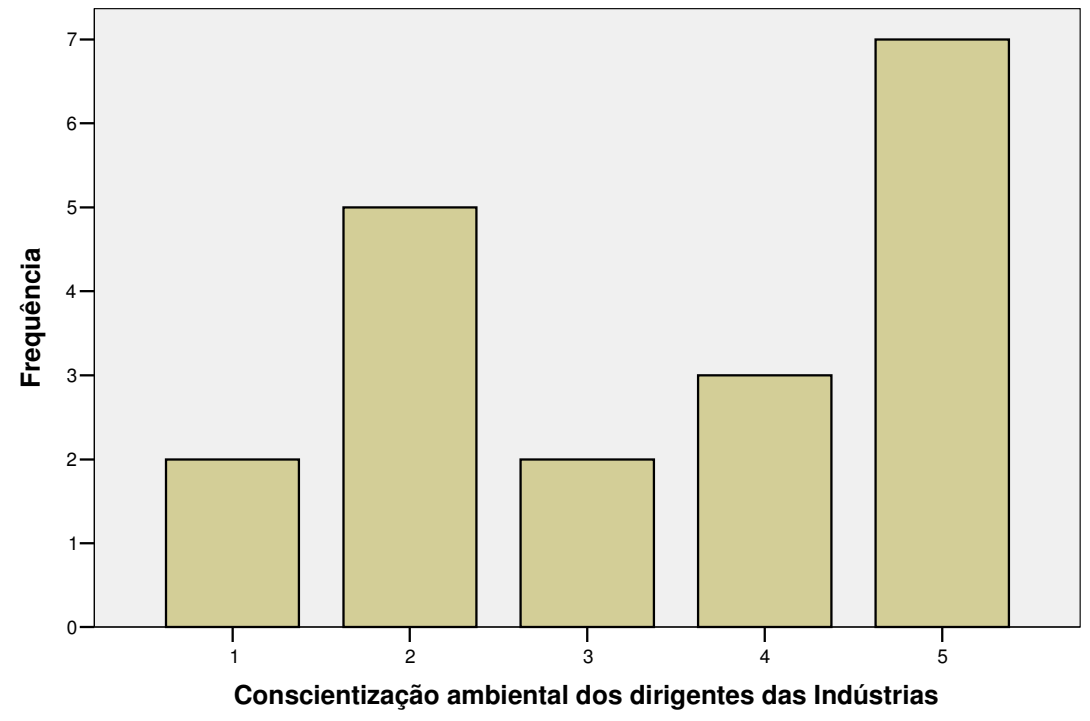

Figura 6 - Distribuição de Freqüências das Ações Civis Públicas movidas pelo Ministério Público por ordem de importância

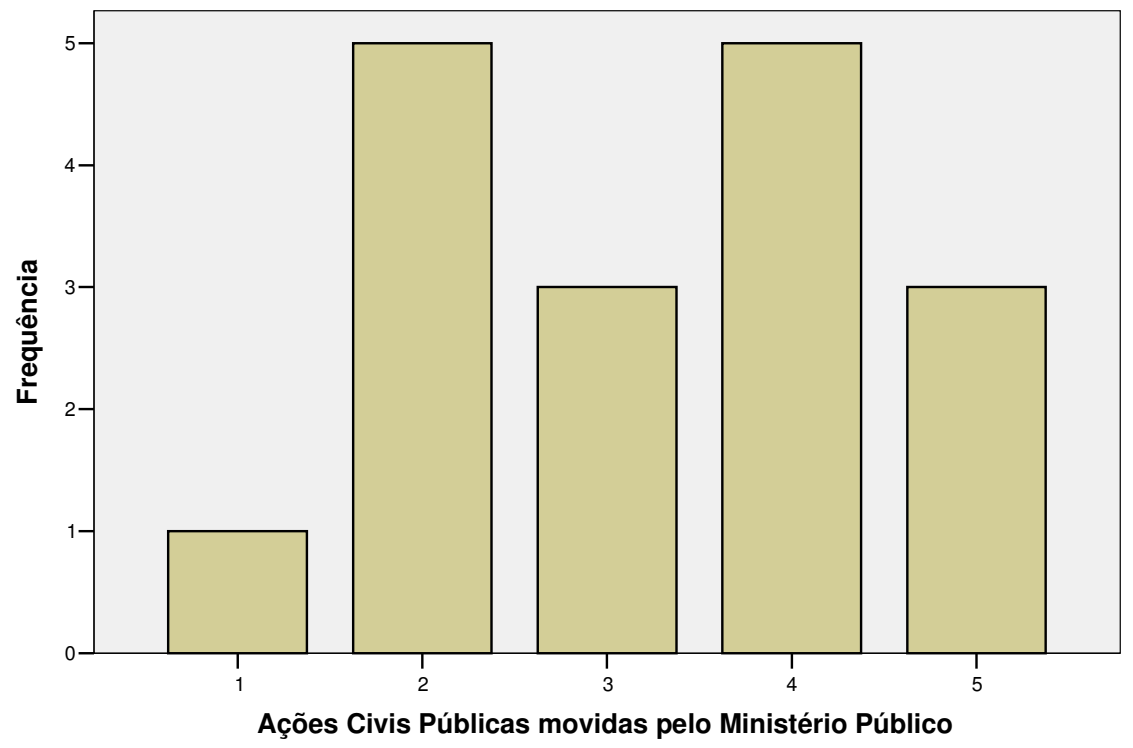


Figura 7 - Distribuição de Freqüência da Pressão da comunidade por ordem de importância

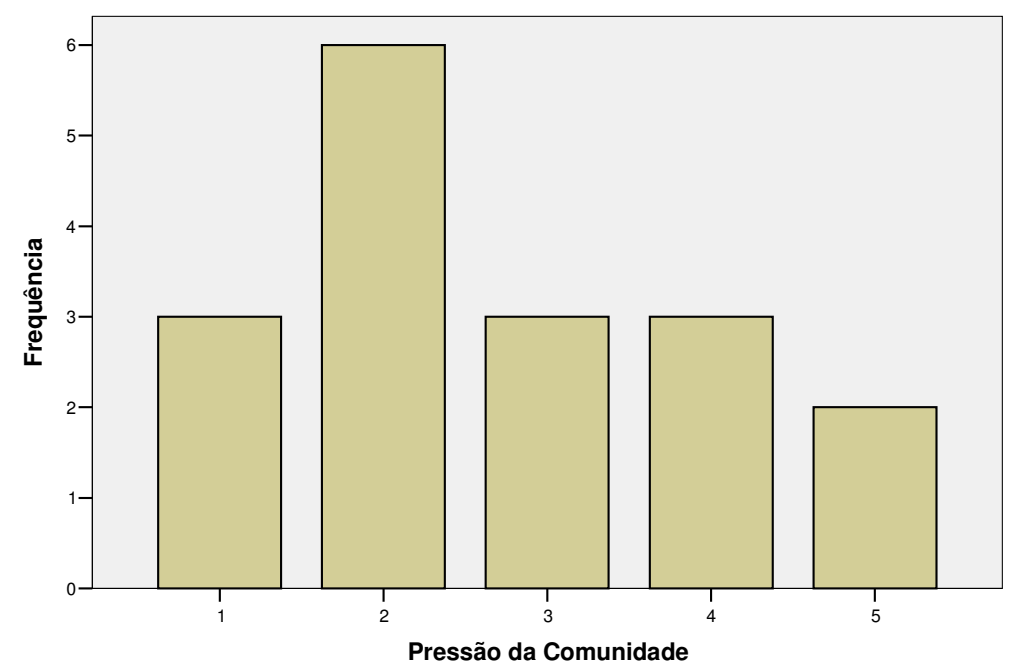

Seguem abaixo alguns gráficos de outros fatores que tiveram menor freqüência de escolha pelos participantes para uma visualização descritiva da distribuição das frequiências em relação à ordem de importância.

Figura 8 - Distribuição de Frequiência da Pressão da Comunidade científica por ordem de importância.

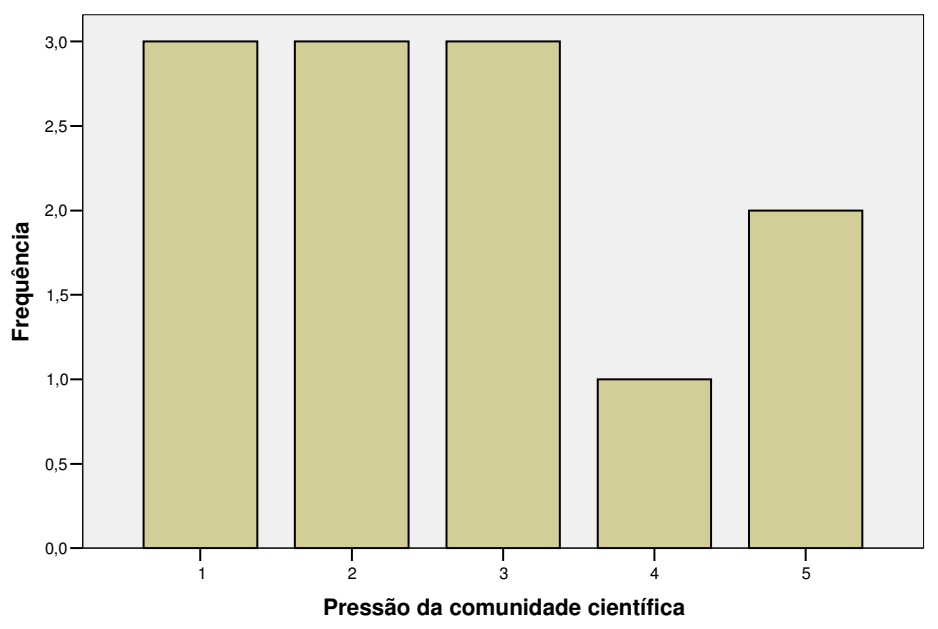


Figura 9 - Distribuição de Freqüência da Edição da Lei dos crimes ambientais por ordem de importância.

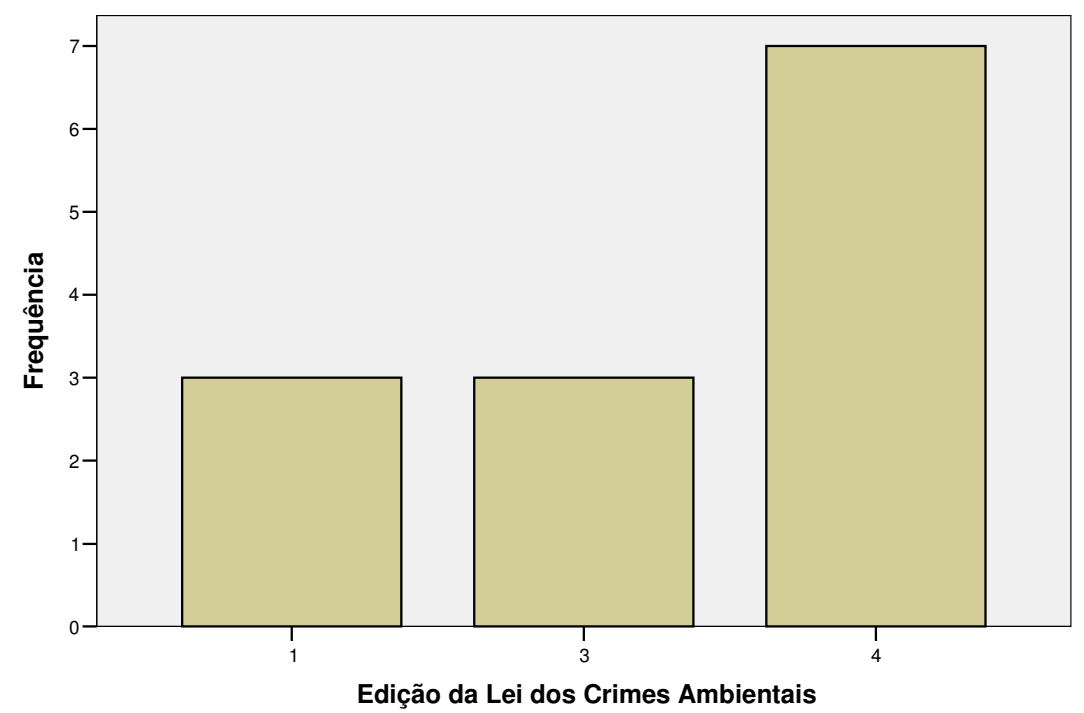

Figura 10 - Distribuição de Freqüência da Orientação e apoio técnico da CETESB por ordem de importância.

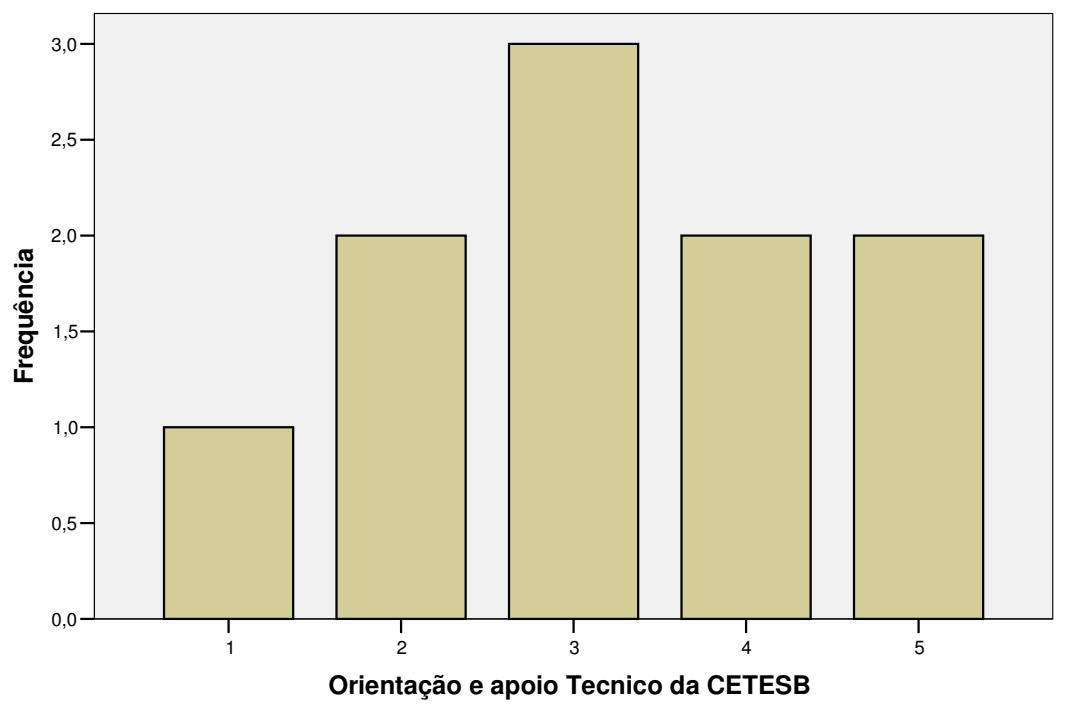


Figura 11 - Distribuição de Freqüência dos Termos de ajustamento de conduta formulados com o Ministério Público por ordem de importância

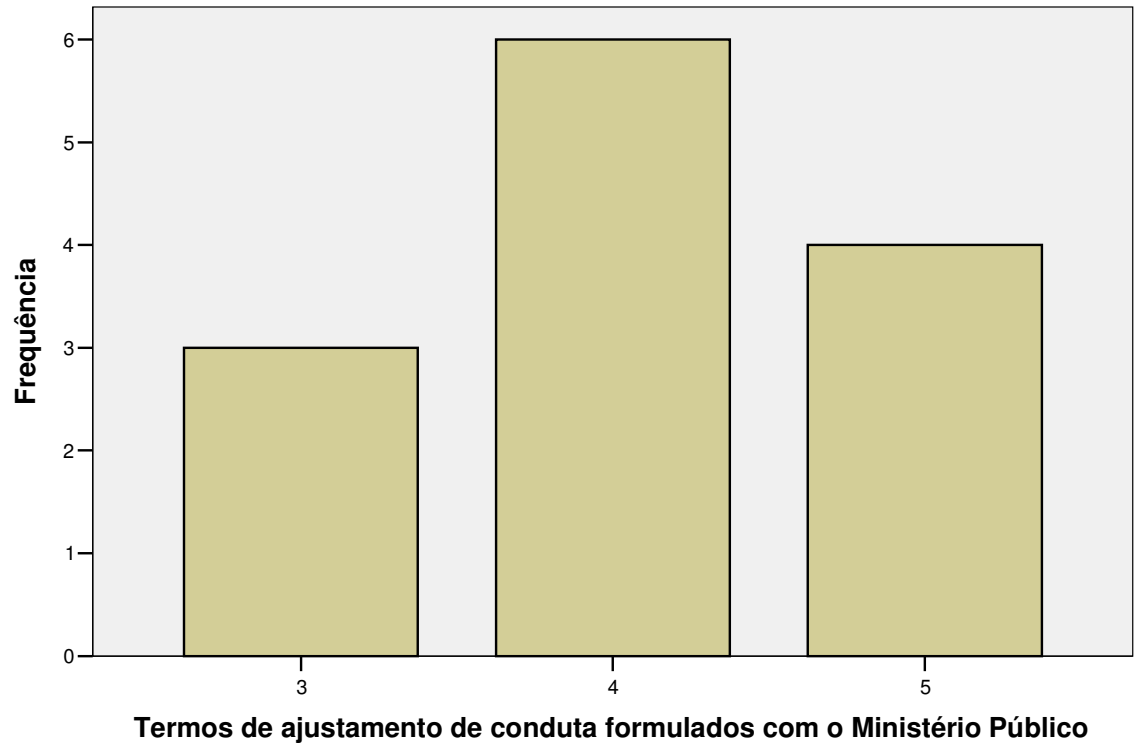

Figura 12 - Distribuição de Freqüência do Avanço dos conhecimentos científicos e tecnológicos por ordem de importância. 


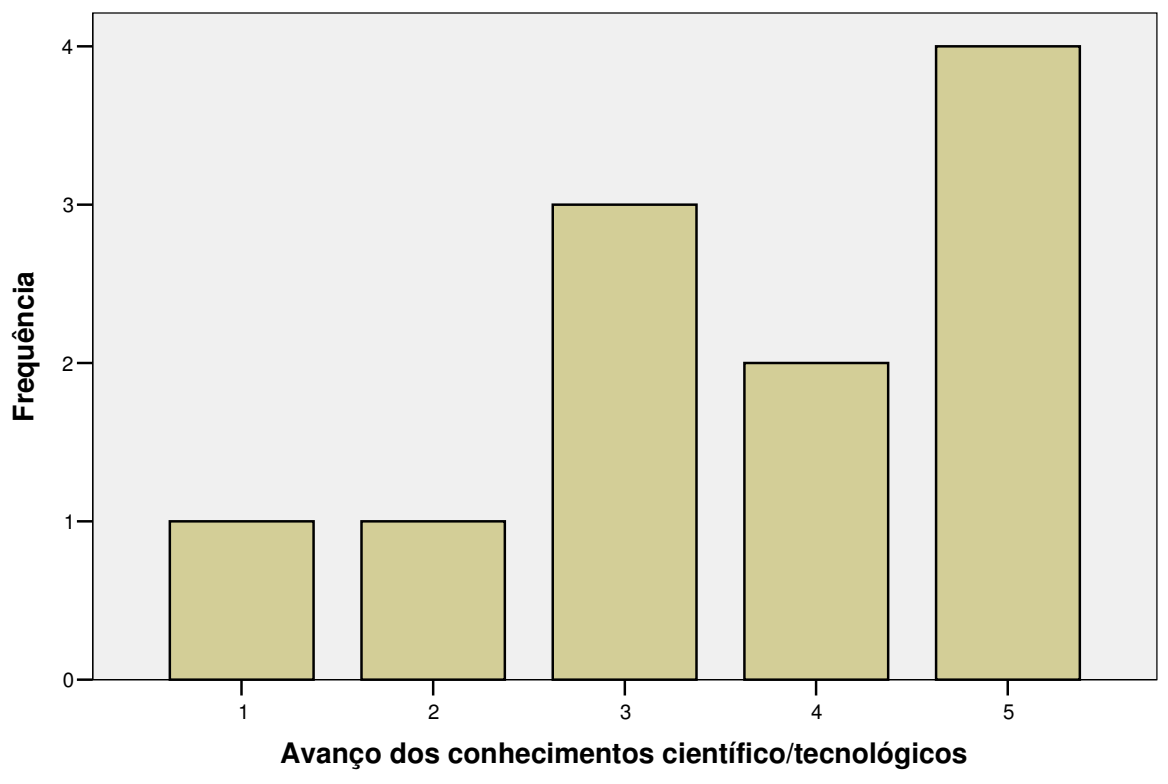

Conforme pode-se observar na Tabela 17 e Figura 3, o fator "Pressão da mídia" foi considerado pela maioria dos participantes como o mais importante fator determinante da evolução do controle da poluição em Cubatão. Esse resultado confirma o papel da imprensa como fundamental no processo que levou à criação e implementação do Programa de Controle da Poluição Ambiental de Cubatão, conforme já mencionado no item 5.2.1., ao tornar público o contexto de degradação ambiental do município e suas conseqüências, de tal maneira que era impossível ao Poder Público ignorar a situação e não tomar qualquer providência para encontrar uma solução.

Verifica-se, também, o fator "Pressão da comunidade do município" dentre os cinco mais votados (Figura 7), demonstrando, a exemplo do que ocorreu em Cubatão, a importância dos movimentos populares para criar a densidade política necessária e suficiente para a tomada das decisões exigidas para a solução dos problemas ambientais e sociais.

Somando-se a esse resultado a considerável votação recebida pelo fator "Pressão da comunidade científica", nota-se a importância da participação e atuação 
da sociedade civil organizada nos processos de decisão, tanto na formulação, quanto na implementação eficaz de políticas públicas ambientais.

Pode-se verificar que os participantes destacaram, ainda, o papel desempenhado pela CETESB na evolução do controle da poluição ambiental em Cubatão, por meio das autuações administrativas, que foi o segundo fator isolado a receber mais votos (ver Figura 4), reconhecendo, também, a importância da orientação e apoio técnico do órgão ambiental para essa evolução, que se encontra dentre os dez fatores mais votados.

Esse resultado demonstra a importância de um órgão ambiental forte e independente na implementação de políticas públicas ambientais, consciente do seu papel na tutela do interesse público.

Observa-se que os participantes enfatizaram a atuação do Ministério Público do Estado de São Paulo na comarca de Cubatão, estando as ações civis públicas movidas pela instituição dentre os cinco principais fatores que teriam determinado a evolução do controle da poluição ambiental no município. O fator "Termos de Ajustamento de Conduta formulados com o Ministério Público" foi o sexto fator mais votado pelos participantes, recebendo a mesma votação do fator "Edição da Lei de Crimes Ambientais".

Esse resultado reforça a importância de instituições fortes e instrumentos legais e processuais adequados para a tutela do meio ambiente e demais interesses difusos e coletivos, bem como o papel central das políticas públicas ambientais para a mudança de comportamento das empresas no trato das questões ambientais, inclusive de regulamentações estabelecendo punições mais graves aos degradadores, como foi o que ocorreu com a edição da Lei dos Crimes Ambientais.

A conscientização ambiental dos dirigentes das indústrias também foi apontada pelos participantes dentre os cinco fatores mais votados como determinantes da evolução do controle da poluição ambiental em Cubatão (Tabela 17 e Figura 5).

Todavia, analisando o resultado geral da questão, em conjunto com a descrição da evolução do programa feita no item 5.2.2. e com as informações obtidas sobre a adoção de sistemas de gestão ambiental pelas empresas, apresentadas no item 5.7., verifica-se que essa "conscientização" não existia no início da implementação 
daquele, sendo as melhorias obtidas inicialmente por força da influência dos demais fatores mais votados, ou seja, das pressões exercidas pela comunidade do município e pela mídia, maculando a imagem das empresas, diante dos impactos negativos sobre o meio ambiente e a saúde pública decorrentes de suas atividades, assim como pela atuação forte da CETESB e do Ministério Público, obrigando as indústrias a adequarem suas atividades à legislação vigente.

Não se pode negar, porém, que ao longo da implementação do programa de controle da poluição ambiental em Cubatão essa conscientização foi ocorrendo gradativamente, conforme demonstra o aumento, a partir do ano 1999, da adoção de sistemas de gestão ambiental pelas empresas (ver item 5.7) e, a partir do ano 2000, do número de Termos de Compromisso de Ajustamento de Conduta formulados com o Ministério Público e CETESB, já mencionado no item 5.3.

Importante mencionar a presença dos fatores "Atuação do Poder Executivo do Município" e "Atuação do Poder Legislativo do Município" dentre os 06(seis) fatores menos votados do total de 20(vinte) fatores propostos (ver Tabela 17). Observa-se, assim, que, segundo a visão dos atores envolvidos, pouca foi a atuação do Poder Público local na melhoria da qualidade ambiental do município.

\subsection{A ATUAL GESTÃO AMBIENTAL DO PÓLO INDUSTRIAL DE CUBATÃO: O DISCURSO DO SUJEITO COLETIVO}

A fim de permitir melhor visualização e compreensão dos resultados dessa questão, a descrição dos resultados qualitativos e quantitativos foi efetuada considerando-se os quatro tópicos em que se dividiu a pergunta, separadamente, ou seja, o entendimento dos participantes quanto à gestão atual do pólo industrial de Cubatão no que se refere ao seguinte: Pontos fracos da gestão atual, Pontos fortes da gestão atual, Ameaças e Oportunidades.

No que se refere aos resultados qualitativos quanto aos pontos fracos da gestão atual, foi possível identificar 10(dez) idéias centrais. No Quadro 19 são apresentadas as idéias centrais identificadas e, na seqüência, cada uma das idéias centrais e os respectivos discursos do sujeito coletivo. 
Quadro 19 - Idéias centrais quanto à questão Pontos fracos da gestão

atual

\section{PERGUNTA}

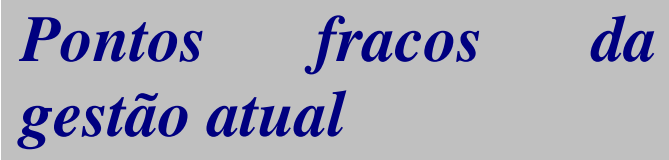

\section{IDÉIAS CENTRAIS}

A-Gestão política em detrimento da técnica

B-Dificuldades burocráticas no trato das questões ambientais, em especial no procedimento de licenciamento

C-Arcabouço legislativo insuficiente, inadequado e desatualizado

D-Conflito entre projetos de crescimento/desenvolvimento

econômico e responsabilidade sócioambiental das empresas

E-Falta de incentivos e/ou vantagens para as empresas que adotem práticas ambientais adequadas

F-Falta de investimentos em estudos ambientais, educação popular e comunicação na área ambiental

G-Falta/deficiência de visão, ação e formação técnica ampliada para a área ambiental

H-Falta de investimentos e inoperância do Poder Público para a área de meio ambiente (ação efetiva, planejamento, controle e fiscalização)

I-Falta de ação integrada entre o setor governamental, empresarial e sociedade civil

J-Precariedade e/ou inexistência do processo de participação da sociedade civil

K-descartada

IDÉIA CENTRAL A

GESTÃO POLÍTICA EM DETRIMENTO DA TÉCNICA 
Considero a atual gestão ambiental do Pólo Industrial de Cubatão muito mais política do que técnica, com exigências que são pouco efetivas ou claras, por serem pouco técnicas.

$O$ desenvolvimento sustentável, que é de interesse de todos (governo, empresários e sociedade civil), requer que as questões ambientais devam ser tomadas com decisões baseadas em informações técnicas e cientificamente consolidadas, o que muitas vezes não está ocorrendo. Do meu ponto de vista este é o ponto mais fraco do sistema de gestão ambiental do país e do Pólo Industrial de Cubatão.

Por exemplo, a Cetesb, no início de suas atividades, funcionava como um órgão técnico de orientação e fiscalização. Ao longo do tempo, verificou-se que sua administração, anteriormente técnica na área ambiental, tem sido exercida por pessoas políticas, sem qualquer vinculação ou conhecimento com o meio ambiente. A Cetesb assim perdeu seus melhores técnicos, que haviam se especializado na orientação, controle e fiscalização ambiental.

$\mathrm{Na}$ Cetesb, ainda existe uma forma de intransigência e também uma falta de coragem e de bom senso da equipe técnica da matriz (São Paulo).

Acho também a atual gestão ambiental muito susceptível à pressão de organizações da sociedade civil, muitas vezes imbuídas de propósitos desvinculados da efetiva proteção ambiental.

Por sua parte, a sociedade civil, incentivada pelos políticos locais, criou nichos de valorização de assistencialismo. Existe realmente um excesso de assistencialismo na comunidade de Cubatão.

\section{IDÉIA CENTRAL B}

\section{DIFICULDADES BUROCRÁTICAS NO TRATO DAS QUESTÕES AMBIENTAIS, EM ESPECIAL NO PROCEDIMENTO DE LICENCIAMENTO}

\section{DSC}

Há um problema quanto ao licenciamento ambiental. Dificuldades burocráticas e lentidão nas análises dos processos de licenciamento ambiental dificultam o crescimento e desenvolvimento tecnológico do Pólo Industrial de Cubatão.

Pode-se dizer que existe uma morosidade na tramitação de processos de licenciamento, que por força da lei proporcionam melhorias ambientais locais e regionais e em casos específicos, em todo território nacional. As estruturas responsáveis pelo processo têm dificuldades de comunicação interna e externa, havendo em muitos casos avaliações antagônicas de processos.

Uma burocracia excessiva, principalmente no que se refere à Secretaria de Meio Ambiente do Estado, está causando um crescimento econômico represado; novos empreendimentos muitas vezes mudam de Estado para viabilização do empreendimento.

Em alguns casos há também conflito de competências sobre quem, governo estadual ou federal, deve licenciar determinado empreendimento. Existe por isso uma necessidade de melhor identificação dos diversos segmentos 
envolvidos nos processos de licenciamento para os novos empreendimentos, o que melhoraria a qualidade e transparência nas exigências de licenciamento.

\section{IDÉIA CENTRAL C}

\section{ARCABOUÇO LEGISLATIVO INSUFICIENTE, INADEQUADO E DESATUALIZADO}

\section{DSC}

A legislação ambiental atual está desatualizada. Acredito que uma legislação mais clara e mais voltada ao meio ambiente dará no futuro um grande retorno para a sociedade civil e gerações futuras.

A ausência de instrumentos legais do município para gerenciamento da qualidade do ar e água representa um grande problema. Em minha opinião, falta a criação por lei do Distrito Industrial de Cubatão, e também de um Código Municipal de Gestão Ambiental.

Por outro lado, a ausência de atualização na legislação estadual, em relação à emissão de poluentes, dificulta a expansão e o crescimento do parque industrial cubatense, pois a fase mais crítica já passou, havendo hoje uma consciência maior de preservação ambiental.

\section{IDÉIA CENTRAL D}

\section{CONFLITO ENTRE PROJETOS DE CRESCIMENTO/DESENVOLVIMENTO ECONÔMICO E RESPONSABILIDADE SÓCIO-AMBIENTAL DAS EMPRESAS}

\section{DSC}

Um ponto fraco na atual gestão ambiental do Pólo Industrial de Cubatão seria a dificuldade em conciliar a proteção ambiental com projetos de desenvolvimento econômico. A busca deste entendimento tem sido com freqüência conflituosa, pois em muitos empreendimentos observamos que é tênue o limite que define simultaneamente os objetivos do empresário, o atendimento às necessidades da sociedade e a proteção ao meio ambiente; ou seja, o desenvolvimento sustentável.

Por um lado pode-se dizer que falta incentivo para o crescimento da indústria em Cubatão; por outro lado falta efetividade por parte das empresas, no compromisso com a questão da responsabilidade sócio-ambiental. Considero esse entendimento entre o crescimento econômico e o problema ambiental um grande desafio para as sociedades modernas.

Por exemplo, as empresas não se comprometem com a preservação, manutenção ou recuperação de áreas protegidas, que de alguma maneira confrontem seus interesses particulares. Elas só atuam de acordo com o grau de pressão do Ministério Público ou da sociedade civil organizada, nunca de forma pró-ativa. Empresário também sempre procura o lucro financeiro.

As empresas demoram em criar soluções para os problemas ambientais sob alegação de restrição financeira, ou pela necessidade de aprovação dos 
projetos na matriz no exterior. O que falta mesmo é melhor planejamento dos empreendimentos; usando um exemplo atual, a dragagem do canal de acesso à Cosipa prevê a construção de uma unidade para depósito de resíduos no Dique do Furadinho que já destruiu o habitat de várias espécies interessantes. A medida mitigatória, que seria a recuperação de várias lagoas e brejos hoje assoreados, ainda nem começou. Como ficam os bichos despejados? É o típico caso em que não se exigiu um cronograma lógico de atividades.

\section{IDÉIA CENTRAL E}

\section{FALTA DE INCENTIVOS E/OU VANTAGENS PARA AS EMPRESAS QUE ADOTEM PRÁTICAS AMBIENTAIS ADEQUADAS \\ DSC}

Em minha opinião, faltam incentivos tributários para as empresas que adotam práticas minimamente poluidoras. Existe pouco ganho em nível de impostos e taxas para empresas que efetivamente investem nas questões ambientais.

\section{IDÉIA CENTRAL F}

\section{FALTA DE INVESTIMENTOS EM ESTUDOS AMBIENTAIS, EDUCAÇÃO POPULAR E COMUNICAÇÃO NA ÁREA AMBIENTAL}

\section{DSC}

Um ponto fraco na atual gestão ambiental é sem dúvida a ausência de um programa de educação ambiental efetivo, voltado para o ensino público, privado e à comunidade como um todo.

Faltam políticas públicas para o desenvolvimento de ações de educação ambiental, o que está se iniciando, com a implementação da Agenda 21 e do programa SEAT.

Cubatão é um Pólo Industrial compacto, por isso, sinto a falta de estudos preventivos nas áreas de saúde (dermatologia, pulmonar-respiratória, toxicidade do sangue, etc.) e também na área ambiental (estudos anátomos patológicos em anfíbios, etc.). Além disso, são poucos os estudos de efeitos eco-toxicológicos.

Outra dificuldade encontrada é a de má comunicação. Apesar de todos os esforços já realizados no Pólo Industrial e os resultados positivos já alcançados, a imagem do Pólo é constantemente associada a fatos negativos do passado. O ponto fraco talvez, seja na divulgação mais ampla e atualizada das melhorias que ocorrem em Cubatão. A divulgação ocorre na região, mas a imagem negativa persiste ao nível nacional. Não existe uma divulgação integrada dos avanços na recuperação ambiental de Cubatão.

É pouca a presença na mídia das ações dos órgãos de controle ambiental e dos resultados. Em minha opinião, falta também um relatório periódico sobre os impactos ambientais.

Todos esses aspectos geram reflexos negativos na gestão do Pólo. 
O que também poderia melhorar é a divulgação periódica por parte do governo sobre as condições ambientais de Cubatão. Por exemplo, a sede da Cetesb, que era em Cubatão, foi transferida para Santos. A partir dessa mudança, a Cetesb vem negligenciando nas obrigações com a cidade, pois como integrante do SISNAMA, teria que informar a comunidade periodicamente sobre as condições ambientais, como era feito no passado. Por absoluta falta de transparência da Cetesb quanto à informação e educação, isso não mais acontece.

E a retirada do aparelho medidor da Avenida Nove de Abril que informava os índices de poluição? Isso também contribuiu pela atual falta de divulgação do nível de poluição.

Considero também um grande problema a ausência de informação por parte das indústrias a respeito dos riscos que os produtos por elas manuseados podem causar a população, pois, caso aconteça algum acidente, os médicos vão ter dificuldades de atender as pessoas afetadas, uma vez que desconhecem os tipos de produtos.

\section{IDÉIA CENTRAL G}

\section{FALTA/DEFICIÊNCIA DE VISÃO, AÇÃO E FORMAÇÃO TÉCNICA AMPLIADA PARA A ÀREA AMBIENTAL.}

\section{DSC}

A gestão atual ainda carece de um melhor esclarecimento e conhecimento sobre técnicas e práticas de gestão ambiental. Em minha opinião alguns itens técnicos deveriam ser mais discutidos, pois ainda existem algumas discordâncias técnicas e imposições sem sentido.

A redução de aporte de recursos financeiros, por parte do governo, para suporte no aperfeiçoamento e formação técnica de profissionais na área ambiental, causou uma falta de pessoas tecnicamente qualificadas no Ministério Público.

Acredito que, hoje em dia, ainda existe uma tendência de reação e não de construção de modelos viáveis, pois há certa dependência de fatos pontuais, quando o correto seria de avaliar o conjunto da obra e o conhecimento racional dos impactos a serem discutidos. Essa situação provoca, na parte mais sensível, insegurança quanto aos verdadeiros motivos e interesses que estão sendo discutidos.

Alem disso, empresas utilizam expedientes e métodos arcaicos de cooptação e manobras relacionadas à gestão de recursos hídricos e formulação de zoneamentos.

Nem todas as indústrias dispõem de um setor cativo para meio ambiente. Normalmente o engenheiro absorve também outros setores da empresa, inclusive produtivos, o que impede o profissional de manter uma gestão efetiva de controle ambiental.

Por outro lado, a capacitação técnica da sociedade civil é limitada, o que gera dificuldade de entendimento, incertezas e desconfianças sobre os impactos ambientais. 


\section{IDÉIA CENTRAL H}

\section{FALTA DE INVESTIMENTOS E INOPERÂNCIA DO PODER PÚBLICO PARA A ÁREA DE MEIO AMBIENTE (AÇÃO EFETIVA, PLANEJAMENTO, CONTROLE E FISCALIZAÇÃO)}

DSC
O setor governamental em Cubatão vive um momento de grave crise,
representada pela "falência múltipla dos órgãos" legislativo e executivo.
Por causa da inoperância atual do Poder Público Municipal (Prefeito), a Por causa da inoperância atual do Poder Público Municipal (Prefeito), a
cidade não dispõe, hoje, de lideranças políticas capazes de assumir o desafio maior para este século: que é a defesa do desenvolvimento sustentável que propicie melhoria da qualidade de vida para sua população.

Em minha opinião, o governo não possui qualquer ingerência pró-positiva, primando pela subserviência e critérios de oportunidade aliados ao sabor de eventuais pressões do Ministério Público ou da sociedade civil organizada, que não forma sua base de sustentação.

Então, o que falta mesmo é ação efetiva, por parte do setor governamental, para reverter o quadro da região que é ambientalmente saturada. Agora que o país precisa crescer economicamente, o governo deveria agir exclusivamente por programas, e não com ações pontuais.

Além do mais, o governo utiliza pouco as ferramentas de gestão e planejamento de qualidade em seus processos de trabalho. Falta planejamento com objetivos e metas bem definidos, o que garantiria maior transparência das medidas que vêm sendo adotadas.

E o problema da fiscalização e controle ambiental? Verifica-se, hoje, ausência de uma permanente fiscalização, eficiente e eficaz, tanto no controle e orientação das fontes de emissão de poluentes, quanto nos equipamentos de proteção, como atividade preventiva e mesmo punitiva.

Acho que é justo dizer que falta um programa ambiental por parte da Cetesb, no tocante a operação e manutenção dos equipamentos e sistemas de controle de poluição. O atual sistema de fiscalização (amostragem de efluentes líquidos e gasosos) é anacrônico e ineficiente, criando problemas para o próprio órgão fiscalizador e mantendo a região na eterna condição de região saturada. Falta também um melhor controle das fontes de poluição por hidrocarbonetos. A Cetesb só vem fazendo o controle do material particulado, pois estes chamam mais a atenção.

Não podemos também esquecer que o foco do Ministério Público muitas vezes é somente nas indústrias sendo que em alguns casos os maiores impactos ambientais estão relacionados à falta de fiscalização do estado e prefeituras quanto à invasão de áreas públicas que são ambientalmente protegidas por lei. Precisamos, por isso, de um maior controle de invasões de áreas públicas.

Falta também capacidade de investimento do governo municipal e estadual, pois o governo deveria investir em áreas como: o controle de tratamento de esgoto, um serviço de toxicologia no Posto de Saúde Central, reflorestamento, na criação de mecanismos de controle do tráfego de cargas perigosas e na 
solução do problema do nosso passivo ambiental: os lixões de Pilões e de Perequê.

Por último o seguinte: há fontes importantes - como a Cosipa - que, se aquilo é estar controlada, eu sou a Madre Teresa. Basta cheirar o lugar para colocar em dúvida a seriedade do programa de controle!

\section{IDÉIA CENTRAL I}

\section{FALTA DE AÇÃO INTEGRADA ENTRE O SETOR GOVERNAMENTAL, EMPRESARIAL E SOCIEDADE CIVIL}

\section{DSC}

Em minha opinião, falta em Cubatão uma integração mais efetiva das ações ambientais, pois ainda é incipiente a discussão franca das questões ambientais. Deveriam ser criados canais eficientes para a discussão de soluções coordenadas, ajudando, entre outras coisas, o governo gerenciar situações de conflito envolvendo o Poder Público. $O$ que melhoraria a eficiência da produção industrial, gerando efeitos na estrutura social e na formatação de um projeto concreto de desenvolvimento sustentado.

Também falta uma maior integração entre as empresas do Pólo nas questões ambientais, com experiência na negociação de acordos e conflitos com os demais segmentos.

Por exemplo, o grau de aproximação empresarial com a comunidade científica é limitado, existe pouca iniciativa empresarial para alavancar estudos e projetos integrados de melhoria ambiental e as empresas tem pequena participação em discussões legislativas.

É preciso também dizer que o setor empresarial, não dispondo de interlocutores à altura no setor governamental, buscou se articular com a sociedade civil para a construção da Agenda 21, iniciativa que só foi possível em virtude da percepção empresarial da inexistência de interlocutores no Poder Público local.

Existe ainda uma ausência de comunicação entre a Cetesb e a comunidade industrial com a comunidade Cubatense a exemplo do que era feito anteriormente.

Também seria importante que o Pólo Industrial de Cubatão atuasse com maior sinergia quanto à reciclagem de resíduos.

\section{IDÉIA CENTRAL J}

\section{PRECARIEDADE E/OU INEXISTÊNCIA DO PROCESSO DE PARTICIPAÇÃO DA SOCIEDADE CIVIL}

\section{DSC}

A sociedade civil, que me parece menos atuante que no passado, relaxa quanto à cobrança para que o plano de controle da poluição em Cubatão não perca seu êxito. 
Pelo histórico da região, muito trabalho foi desenvolvido por entidades não governamentais, movimentos que foram louváveis em uma época em que o assunto era de urgência e requeria medidas mais urgentes. Hoje ainda existem movimentos que se utilizam da mesma abordagem que se usava em outra época. O nível de diálogo mudou e seria importante que a participação desses movimentos pudesse ser feita de forma mais efetiva, defendendo os seus interesses, mas com abordagens mais objetivas, podendo trazer propostas a serem discutidas.

A sociedade civil também não possui articulação e ferramentas suficientes para fazer frente às importantes questões ambientais da região. Em minha opinião, a sociedade civil deveria ter uma participação pró-ativa no que tange as tomadas de decisões relacionadas aos novos investimentos no Pólo.

A maioria das ONGs existentes na Baixada Santista estão comprometidas com o setor industrial em detrimento das ações de controle. Ocorre com sensível parcela das organizações da sociedade civil, a cooptação de lideranças que trocam favores ora com a municipalidade, ora com o empresariado.

Outro problema, hoje em dia é o pouco envolvimento da comunidade. Em Cubatão, o esvaziamento social é crescente, com as pessoas indo embora da cidade. A classe média incipiente resiste, porém, não criou ainda condições para se articular politicamente e oferecer um projeto alternativo de poder, capaz de garantir a recuperação da cidade. O nível de organização é ainda incipiente. As entidades de bairro estão muitas vezes presas a uma política clientelista, mantida por políticos sem nenhuma visão estratégica da cidade.

Acredito que a sociedade está desmobilizada e desmotivada para exercer seus direitos de cidadania em buscar providências, para que a Cetesb volte a cumprir suas obrigações.

O que também acontece é que a Cetesb está distanciada da comunidade. Um exemplo: $O$ fim do atendimento das reclamações e denúncias feitas direto ou por telefone junto à agência da Cetesb em Cubatão, que mantinha, por vinte e quatro horas plantonistas na agência. Atualmente, nos finais de semana, feriados e a noite as reclamações e denúncias somente podem ser feitas através do telefone que fica na capital, o que dificulta e desestimula a comunidade, pois, dá a impressão de que tudo está sob controle. O que não é verdade, pois, na bacia da Vila Paris a emissão de material particulado é visível.

E ainda tem a falta de capacidade por parte da sociedade civil organizada de enfrentar o sistema capitalista, pois, o marketing mantido pelo capitalismo se coloca como um formador de opinião massificando as suas idéias de produção e consumo que promovem o desequilíbrio ambiental.

Conforme pode-se observar dos DSC produzidos, a maioria dos participantes, ao responder à questão, não efetuou a separação dos pontos fracos da gestão atual em relação aos diversos setores estabelecidos na indagação (setor governamental, empresarial e sociedade civil). Entretanto, foi possível fazer essa separação, 
sintetizando os principais aspectos apontados sobre cada setor, a partir do conteúdo dos discursos, conforme apresentado abaixo:

\section{A. Setor governamental}

1) predomínio da gestão ambiental política sobre a gestão técnica do Pólo industrial de Cubatão;

2) insuficiência e inadequação das políticas públicas ambientais atualmente estabelecidas para uma gestão mais eficiente do complexo industrial, havendo necessidade de atualização legislativa, em especial quanto ao procedimento de licenciamento;

3) ausência de instrumentos econômicos que possam incentivar as empresas à adoção de práticas ambientais mais adequadas;

4) investimentos e ações incipientes do Poder Público na área ambiental, tanto no sentido de propiciar melhor capacitação técnica de seus agentes, quanto na realização de ações planejadas mais efetivas e integradas, que envolvam todos os problemas do município, bem como todos os setores interessados;

5) dependência de fatos pontuais e atuação caracterizada por reações a pressões do Ministério Público ou da sociedade civil organizada;

6) ausência de políticas públicas para o desenvolvimento de ações de educação ambiental, visando à capacitação da população para discutir e participar da elaboração e implementação das políticas públicas ambientais;

7) ausência de informações adequadas disponíveis à população;

8) ausência de comunicação da CETESB com a comunidade;

9) ausência de estudos preventivos na área de saúde e de meio ambiente;

10) sistema de fiscalização e controle ineficiente e anacrônico, criando problemas para o próprio órgão fiscalizador e contribuindo para manter a região na condição de saturada;

11) falta de controle de invasões de áreas públicas; 
12) falta de ação integrada entre os setores governamental, empresarial e sociedade civil.

Alguns pontos fracos dizem respeito especificamente ao setor governamental municipal, motivo pelo qual são apresentados em separado:

1) ausência de instrumentos legais municipais de gestão;

2) inoperância do setor governamental do município, havendo a ‘falência múltipla dos órgãos' legislativo e executivo.

\section{B. Setor empresarial}

1) falta de comprometimento efetivo das empresas com a questão da responsabilidade sócio-ambiental;

2) falta de ações pró-ativas, atuando somente em reação às pressões recebidas do Poder Público ou da sociedade civil organizada;

3) planejamento inadequado dos empreendimentos;

4) ausência de comunicação com a comunidade;

5) ausência de setor específico de meio ambiente em todas as indústrias, dificultando a gestão ambiental;

6) falta de maior aproximação com a comunidade científica;

7) falta de ação integrada entre os setores governamental, empresarial e sociedade civil.

\section{Sociedade civil}

1) capacitação técnica limitada, gerando dificuldades de entendimento, incertezas e desconfianças;

2) redução da atuação, com pouco envolvimento nas questões ambientais da cidade;

3) falta de efetividade na participação de entidades não governamentais na discussão dos problemas ambientais; 
4) ausência de instrumentos adequados para a participação da sociedade civil no processo de tomada de decisões;

5) comprometimento da maioria das ONGs da Baixada Santista com o setor industrial;

6) nível de organização incipiente da sociedade civil, que se apresenta desmobilizada e desmotivada para exercer seus direitos;

7) entidades de bairro presas a uma política clientelista;

8) falta de capacidade da sociedade civil organizada de enfrentar o sistema capitalista;

9) falta de ação integrada entre os setores governamental, empresarial e sociedade civil.

Os resultados quantitativos desse aspecto podem ser observados na Figura 13.

Figura 13- Distribuição das Idéias Centrais, segundo os participantes, frente à questão Pontos fracos da gestão atual, Cubatão, São Paulo, 2007. 


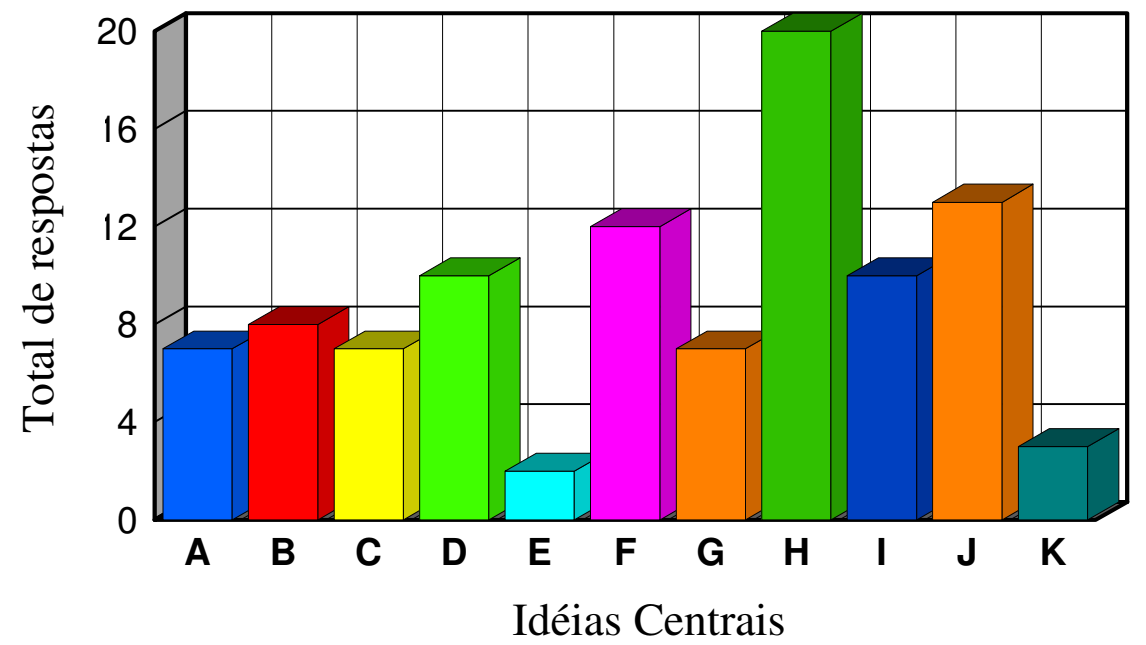

A-Gestão política em detrimento da técnica

B-Dificuldades burocráticas no trato das questões ambientais em especial no processo de licenciamento

C-Arcabouço legislativo insuficiente, inadequado e desatualizado

D-Conflito entre projetos de crescimento/desenvolvimento econômico e responsabilidade sócio- ambiental das empresas

E-Falta de incentivos e/ou vantagens para as empresas que adotem práticas ambientais adequadas

G- Falta/deficiência de visão, ação e formação técnica ampliada para a àrea ambiental

H-Falta de investimentos e inoperância do Poder Público para a área de meio ambiente (ação efetiva, planejamento, controle e fiscalização)

I-Falta de ação integrada entre o setor governamental, empresarial e sociedade civil

J-Precariedade e/ou inexistência do processo de participação da sociedade civil

K-Descartada

F-Falta de investimentos em estudos ambientais, educação popular e comunicação na área ambiental

Analisando o resultado quantitativo das respostas, a partir de cálculo percentual, considerando o total de respostas obtidas para a pergunta (99 respostas), verifica-se que a falta de investimentos e ações efetivas do Poder Público na área de meio ambiente foi o aspecto mais apontado pelos participantes como ponto fraco da atual gestão ambiental do pólo industrial de Cubatão $(\mathrm{H})$. Os dois aspectos mais apontados na seqüência estão intimamente relacionados com o primeiro, ou seja, a 
ausência ou precariedade da participação da sociedade civil nesse processo de gestão (J), que pode ser justamente conseqüência do terceiro aspecto mais apontado pelos participantes da pesquisa: a falta de investimentos em capacitação da população e informação adequada na área ambiental (F).

Nota-se, ainda, somando-se as idéias centrais B, C, E, H e I dos discursos do sujeito coletivo resultantes da pesquisa, que o principal aspecto apontado pelos participantes como ponto fraco da atual gestão ambiental do pólo industrial de Cubatão diz respeito à insuficiência e inadequação das políticas públicas ambientais atualmente estabelecidas, tanto no que se refere ao aspecto formal da legislação, quanto à sua tradução em ações práticas efetivas.

No que se refere aos pontos fortes da gestão atual foi possível identificar 09 (nove) idéias centrais. No Quadro 20 são apresentadas as idéias centrais identificadas e, na seqüência, cada uma das idéias centrais e os respectivos discursos do sujeito coletivo. 
Quadro 20 - Idéias centrais quanto à questão Pontos fortes da gestão

atual

\section{PERGUNTA}

Pontos fortes da gestão atual

\section{IDÉIAS CENTRAIS}

A-Conscientização ambiental do setor industrial, assumindo sua responsabilidade social

B-Organização e estabelecimento do projeto de planejamento de longo prazo "Agenda 21"

C-Educação popular na área ambiental

D-Sociedade civil mais organizada e participativa

E-Intensificação do controle e da fiscalização por parte dos órgãos ambientais

F-Nível elevado de competência e profissionalismo dos órgãos públicos

G-Forte interação entre o setor governamental, empresarial e a sociedade civil

H-Entendimento comum sobre importância das questões ambientais

I-Farta legislação

J-Descartada

\section{IDÉIA CENTRAL A}

\section{CONSCIENTIZAÇÃO AMBIENTAL DO SETOR INDUSTRIAL, ASSUMINDO SUA RESPONSABILIDADE SOCIAL}

\section{DSC}

Acredito que um dos pontos fortes da atual gestão ambiental de Cubatão seja a conscientização dos empresários e investidores modernos, da inquestionável necessidade do controle e preservação ambiental. Boa parte do empresariado entendeu a importância da variável ambiental na condução do seu negócio.

Essa responsabilidade ambiental tem proporcionado, embora com falhas, mais investimento na política de prevenção e controle da poluição, além da formulação de termos de ajustamento de conduta com o Ministério Público. A conscientização ambiental do setor industrial representou uma mudança cultural significativa na gestão das unidades industriais.

A pró-atividade das empresas do Pólo Industrial de Cubatão em resolver os problemas apresentados gerou investimentos em melhorias tecnológicas com 
conseqüente diminuição da poluição. Foram criados sistemas internos de gestão e controle ambiental, na busca das melhores práticas. O setor industrial deu início a treinamentos para o público interno e externo referente à conscientização ambiental, padronização de rotinas operacionais e maior difusão dos conhecimentos a outras áreas.

A colaboração das empresas cumprindo as exigências dos órgãos competentes resultou até mesmo na paralisação de plantas industriais para melhorar a qualidade ambiental do município.

Houve também uma maior procura das indústrias por certificações de sistemas de gestão ambiental baseados na norma NBR-ISO-14001, buscando uma maior eficiência dos seus processos.

A participação das indústrias nos debates públicos aumentou significativamente. Os dirigentes industriais passaram a se relacionar com a comunidade local de uma maneira positiva, passando a vê-la como aliada, $e$ não como inimiga, discutindo os problemas com transparência na busca por soluções.

Devo também destacar a entrada em cena do setor empresarial com a proposta de articular a comunidade para a discussão da Agenda 21. Essa iniciativa, além de oportuna, representa uma esperança de que, a partir dela, possam surgir lideranças capazes de construir um projeto político e inclusivo, com condições de disputar o poder na cidade e mudar os rumos.

\section{IDÉIA CENTRAL B}

\section{ORGANIZAÇÃO E ESTABELECIMENTO DO PROJETO DE PLANEJAMENTO DE LONGO PRAZO "AGENDA 21"}

\section{DSC}

Agenda 21 de Cubatão concluída, pois ela contempla (endereça) muitos dos maiores desafios da região.

\section{IDÉIA CENTRAL C}

\section{EDUCAÇÃO POPULAR NA ÁREA AMBIETAL}

DSC

Um dos pontos fortes da atual gestão deve ser a educação ambiental. Por exemplo, a capacitação dos diversos setores há de melhorar, através de disseminação de conhecimento nas áreas ambientais.

\section{IDÉIA CENTRAL D}

\section{SOCIEDADE CIVIL MAIS ORGANIZADA E PARTICIPATIVA}

\section{DSC}


Em minha opinião a sociedade civil está mais esclarecida e participativa. Ela está também mais organizada, mais transparente e procurando mais o diálogo. Em franco processo de evolução e organização, a sociedade civil está tornando mais responsável sua atuação em processos decisórios e respeitando os graus de ação e conhecimento para dialogar com as forças de controle e de produção. Ela está participando efetivamente de discussões de interesse do desenvolvimento da região, cobrando forte atuação na questão ambiental.

A sociedade civil está também mais presente em audiências públicas.

Além de tudo isso, a população em geral está mais conscientizada da situação atual e das mudanças necessárias, participando mais na Agenda 21.

Acredito que a atuação de ONGs, que oferecem subsídios aos membros do Ministério Público, para o cumprimento da legislação e normas de controle vigentes, também é muito importante.

\section{IDÉIA CENTRAL E}

\section{INTENSIFICAÇÃO DO CONTROLE E DA FISCALIZAÇÃO POR PARTE DOS ÓRGÃOS AMBIENTAIS}

\section{DSC}

Acredito que um ponto forte da atual gestão seja o maior rigor na implantação de medidas de controle à poluição, com destaque à fiscalização por parte dos órgãos competentes e também a atuação presente do Ministério Público. Os órgãos governamentais estão muito presentes na região e fazem intensa fiscalização.

A ação efetiva da Cetesb, do Ministério Público e da Prefeitura Municipal de Cubatão na fiscalização ambiental vem proporcionando melhores atuações, produzindo respostas mais rápidas e eficientes no que diz respeito à contaminação do solo.

Atualmente, o órgão de controle ambiental está bem aparelhado, com um controle de emissões mais moderno, até mesmo "on-line".

São esses investimentos constantes no controle ambiental que não estão permitindo o retorno a um passado ainda recente.

\section{IDÉIA CENTRAL F}

\section{NÍVEL ELEVADO DE COMPETÊNCIA E PROFISSIONALISMO DOS ÓRGÃOS PÚBLICOS}

\section{DSC}

Reconheço que temos hoje uma gestão sólida e com técnicos ambientais experientes. Nos últimos anos, houve realmente uma melhoria do nível de competência e exigências técnicas aplicadas e desenvolvidas pelos órgãos públicos. Resultado de uma ação corajosa, inteligente e prática da promotoria local do meio ambiente e do gerente local da Cetesb. 
O sistema de gestão ambiental foi implantado, os riscos ambientais identificados e administrados e, além disso, os órgãos ambientais atuam hoje como orientadores e fiscalizadores ao mesmo tempo.

O sistema de gestão ambiental não está só mais focado no controle da poluição, abordagem reativa, que visa atender as preocupações básicas de cumprimento de legislações, e sim na prevenção da poluição, abordagem próativa. Neste sistema de prevenção da poluição, há uma combinação de duas preocupações básicas que são o uso sustentável dos recursos e o controle da poluição.

Além do mais, as regras estão bem definidas para a gestão ambiental das empresas e uma parcela importante dos dirigentes industriais já foi ambientalmente "catequizada".

Existe hoje uma maior orientação e apoio técnico por parte da Cetesb, que vistoria e acompanha os processos industriais nas diversas empresas do Pólo pelo órgão ambiental. Por isso, ao contrário da década de 1980, hoje existe para quem reclamar quem vai te ouvir. Não é como quando havia apenas a Cetesb do governo Maluf. Além disso, a Cetesb exerce uma função básica de divulgação de indicadores, que é um trabalho de fim específico para o qual foi constituída.

Foi também importante a parceria do governo local com o Ministério Público, na solução de problemas ambientais difíceis de resolver. Notável é a eficiência com que o Ministério Público tem usado na lei 8078/90 artigo 113 parágrafo $6^{\circ}$, elaborando termos de ajustamento de conduta buscando minorar os males causados à comunidade pelo Pólo Industrial. A atuação do Ministério Público tem respondido as expectativas da comunidade quanto a identificação $e$ punição dos responsáveis pelos danos ambientais.

\section{IDÉIA CENTRAL G}

\section{FORTE INTERAÇÃO ENTRE O SETOR GOVERNAMENTAL, EMPRESARIAL E A SOCIEDADE CIVIL}

\section{DSC}

Um ponto forte da atual gestão ambiental de Cubatão é a forte interação entre o setor governamental, empresarial e a sociedade civil, havendo muitas oportunidades para discutir assuntos de interesse comum, bem como abertura entre as partes para apresentação e discussão de novos temas elou projetos. O setor governamental está mais aberto ao diálogo e negociação; tem visão de conjunto; discute mais abertamente os problemas e pontos de preocupação, tudo isso na busca de parceiros para resolução das carências. A relação entre empresas e órgãos públicos melhorou significativamente. Foi desenvolvida uma parceria entre os órgãos de controle: Cetesb, Ministério Público e empresas.

O novo diálogo entre governo, empresariado e comunidade, foi facilitado pela experiência adquirida ao longo dos anos bem como, na implantação do Conselho Consultivo Comunitário como fórum de debate. Essa forte 
interação criou uma imagem de recuperação ambiental como trabalho conjunto da sociedade, governo e empresariado.

\section{IDÉIA CENTRAL H}

\section{ENTENDIMENTO COMUM SOBRE IMPORTÂNCIA DAS QUESTÕES AMBIENTAIS}

\section{DSC}

Existe hoje um entendimento comum de que as questões ambientais são extremamente importantes para o mundo e sobrevivência das organizações. A alta conscientização por parte de todos os setores resultou em uma busca pela melhoria contínua por parte de todos os segmentos da sociedade. $O$ que criou investimentos constantes em ações de controle de poluição.

Existe mesmo, de uma maneira geral, maior conscientização ambiental das comunidades.

Nos últimos anos, houve um levantamento dos problemas ambientais de uma forma geral e foram feitas propostas, embora não claras e objetivas, de melhorias da situação ambiental de Cubatão. Isto foi o resultado de uma mudança de mentalidade ambiental, de uma visão mais aberta ou holística dos gestores das empresas e dos órgãos competentes, que acompanharam a evolução presente em âmbito.

\section{IDÉIA CENTRAL I}

\section{FARTA LEGISLAÇÃO}

\section{DSC}

Considero um ponto forte na atual gestão ambiental de Cubatão, a farta legislação ambiental, como ferramenta essencial para os operadores do direito, na exigência do cumprimento da norma legal e de punição aos desobedientes e infratores, ou de substituições ou reposições de áreas degradadas.

Os principais aspectos apontados pelos participantes como pontos fortes da gestão atual, obtidos a partir do conteúdo dos discursos, separados por setor (setor governamental, empresarial e sociedade civil), conforme estabelecido na indagação, são apresentados sinteticamente abaixo:

\section{A. Setor governamental}


1) forte presença, intensa fiscalização e ação efetiva dos órgãos governamentais na região;

2) investimentos no aparelhamento do órgão de controle ambiental (CETESB), possibilitando a adoção de métodos mais modernos de fiscalização, como o monitoramento "on line" de emissões;

3) nível elevado de competência dos órgãos governamentais;

4) orientação e apoio técnico fornecidos pela CETESB;

5) educação ambiental;

6) divulgação de indicadores pela CETESB;

7) atuação eficiente do Ministério Público, especialmente por meio dos termos de ajustamento de conduta;

8) existência de farta legislação ambiental para dar suporte às ações;

9) visão holística da situação ambiental do município;

10) forte interação entre os setores governamental, empresarial e sociedade civil, com abertura de fóruns de discussão dos problemas ambientais.

\section{B. Setor empresarial}


1) conscientização ambiental do setor industrial;

2) conduta pró-ativa das empresas do pólo industrial de Cubatão na solução dos problemas ambientais, baseadas na prevenção da poluição, resultando em melhorias tecnológicas e de gestão ambiental;

3) implantação de sistemas de gestão ambiental, em especial baseados na norma NBR-ISO-14001;

4) iniciativa de organização e estabelecimento da Agenda 21 do município;

5) visão holística da situação ambiental do município;

6) forte interação entre os setores governamental, empresarial e sociedade civil, com abertura de fóruns de discussão dos problemas ambientais.

\section{Sociedade civil}

1) maior organização e participação nos processos decisórios, inclusive em audiências públicas;

2) maior conscientização da situação ambiental do município e das mudanças necessárias;

3) oferecimento de subsídios ao Ministério Público para a tutela do meio ambiente, em especial por ONGs;

4) educação ambiental;

5) forte interação entre os setores governamental, empresarial e sociedade civil, com abertura de fóruns de discussão dos problemas ambientais.

Na Figura 14 pode-se observar os resultados quantitativos desse aspecto. 
Figura 14 - Distribuição das Idéias Centrais, segundo os participantes, frente à questão Pontos fortes da gestão atual, Cubatão, São Paulo, 2007.

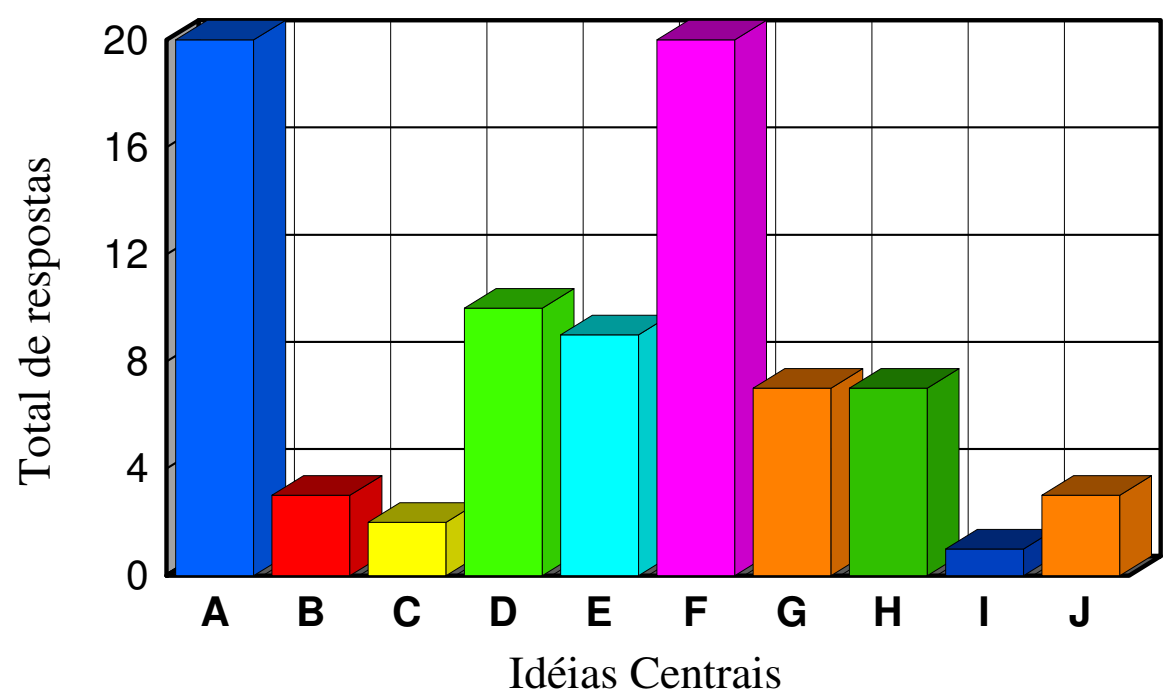

A-Conscientização ambiental do setor social

B-Organização e estabelecimento do projeto de planejamento de longo prazo "Agenda 21"

C-Educação popular na área ambiental

D-Sociedade civil mais organizada e participativa

E-Intensificação do controle e da fiscalização por parte dos órgãos ambientais

F-Nível elevado de competência e profissionalismo dos órgãos públicos

G-Forte interação entre o setor governamental, empresarial e a sociedade civil

H-Entendimento comum sobre a importância das questões ambientais

I-Farta legislação

J-Descartada

Analisando o resultado quantitativo das respostas, a partir de cálculo percentual, considerando o total de respostas obtidas para a pergunta (82 respostas), verifica-se que a conscientização ambiental do setor industrial, assumindo sua responsabilidade social (A), e o nível elevado de competência e profissionalismo dos órgãos públicos (F) foram os aspectos mais apontados pelos participantes como pontos fortes da atual gestão ambiental do pólo industrial de Cubatão, atingindo o mesmo percentual de escolha. Os dois aspectos mais apontados na seqüência dizem 
respeito à melhor organização e participação da sociedade civil no processo de gestão (D), seguido da intensificação do controle e da fiscalização por parte dos órgãos ambientais (E).

No que se refere às ameaças à gestão ambiental do pólo industrial de Cubatão também foi possível identificar 09 (nove) idéias centrais. No Quadro 21 são apresentadas as idéias centrais identificadas e, na sequiência, cada uma das idéias centrais e os respectivos discursos do sujeito coletivo.

Quadro 21 - Idéias centrais quanto à questão Ameaças

\section{PERGUNTA}

\section{Ameaças}

\section{IDÉIAS CENTRAIS}

A-Crescimento industrial freado pela rigidez das medidas ambientais

B-Relaxamento por parte dos órgãos ambientais no controle e na fiscalização ambiental

C-Crescimento urbano desordenado e ocupação de áreas protegidas

D-Interesses políticos, pessoais ou ideológicos em detrimento do desenvolvimento sustentável

E-Pouco investimento em educação ambiental

F-Crescimento do pólo industrial de Cubatão considerado mais importante que o combate à poluição

G-Má administração e falta de investimentos por parte do governo na área ambiental

H-Relacionamento precário entre setor governamental, empresarial e sociedade civil, diminuindo a possibilidade de diálogo

I-Falta de legislação específica para a região do Pólo Industrial de Cubatão

J-Descartadas 


\section{IDÉIA CENTRAL A}

\section{CRESCIMENTO INDUSTRIAL FREADO PELA RIGIDEZ DAS MEDIDAS AMBIENTAIS}

\section{DSC}

Em meu entendimento uma ameaça ao atual sistema, seria a impossibilidade de crescimento ou expansão das atividades industriais em Cubatão. A ausência de novos investimentos no parque industrial, em razão das restrições impostas pelos órgãos ambientais para o licenciamento de unidades industriais, forma uma ameaça real ao Pólo.

A falta de perspectiva para ampliação do parque industrial em atendimento a uma demanda de crescimento necessária ao desenvolvimento do país, poderia resultar na perda de competitividade dos empreendimentos. Com a atual globalização do mercado, nunca se sabe o que pode acontecer.

A fuga de investimentos privados para regiões com menor "exigência" no controle da poluição e a perda de mão de obra extremamente especializada por conta do crescimento de demanda em outros Pólos, teria como possível conseqüência estagnação elou fechamento de fabricas em Cubatão. Neste caso, as indústrias empregariam cada vez menos trabalhadores de Cubatão.

O Brasil tem a melhor legislação ambiental do planeta, mas seu cumprimento se dá, parcialmente, no Estado de São Paulo. A poluição não tem fronteiras. A indústria paulista vem encolhendo e nos demais estados da federação, crescendo. O que queremos?

Uma outra ameaça ao crescimento industrial vem de ser a falta de planejamento para o aumento da capacidade dos portos da região. O que pode ocasionar congestionamentos e conseqüentemente maior emissão de gases e particulados, fazendo com que as indústrias sejam afetadas mesmo não tendo responsabilidade e controle sobre isto.

O que falta mesmo é uma visão mais geral, pois a época em que se podia tudo se passou, a que não se permite nada também. Hoje se deve optar pelas soluções que trazem o maior ganho social com a menor perda ambiental.

\section{IDÉIA CENTRAL B}

\section{RELAXAMENTO POR PARTE DOS ÓRGÃOS AMBIENTAIS NO CONTROLE E NA FISCALIZAÇÃO AMBIENTAL}

DSC

Considero a descontinuidade da fiscalização e a diminuição das atividades de controle uma ameaça ao atual sistema de gestão ambiental em Cubatão. $O$ obsoletismo dos órgãos de controle e fiscalização ambiental, bem como a falta de uma infra-estrutura moderna e atualizada e de apoio aos órgãos do ministério público, comprometerão certamente a atuação constante $e$ permanente, nas áreas de preservação e controle do meio ambiente. 
Igualmente, o relaxamento da Cetesb, de certa forma, tem contribuído para o comodismo tanto da comunidade industrial como principalmente da comunidade Cubatense. A Cetesb não é mais a mesma da década de oitenta. Os técnicos mais experientes foram retirados da nossa cidade. $O$ monitoramento do material particulado há muito deixa a desejar, assim como sempre ocorreu com emissão de gases. Embora tenha havido avanços no combate e controle da poluição, a vigilância rigorosa deve ter continuidade, sob pena de retrocesso. O rótulo de cidade símbolo da ecologia de certa maneira contribuiu para o comodismo hoje existente.

De outra parte, a ausência de controle e acompanhamento popular do Plano de Controle tornou impossível fazer uma avaliação da real situação em que o mesmo se encontra. Não se sabe, por exemplo, quais foram os investimentos das indústrias nos últimos anos; se foram feitos investimentos de vulto nas novas tecnologias. Não se pode precisar exatamente se houve um controle efetivo das fontes de poluição ou se, ao longo dos últimos anos, elas não foram camufladas, inclusive, com recursos de propaganda.

Acredito que a ameaça sob o ponto de vista de re-poluição excessiva sempre existirá, notadamente se o poder público "relaxar" nas suas atividades de investigação obtida por denúncias da população local.

\section{IDÉIA CENTRAL C}

\section{CRESCIMENTO URBANO DESORDENADO E OCUPAÇÃO DE ÁREAS PROTEGIDAS}

\section{DSC}

Uma ameaça real à atual gestão ambiental vem a ser o crescimento urbanístico desordenado e a invasão de áreas públicas. Acredito que a ocupação desordenada e descontrolada pode gerar problemas muito maiores do que os existentes e inviabilizar a continuidade operacional das indústrias no futuro.

O desenvolvimento descontrolado muitas vezes é causado pela extrema lentidão na implantação de áreas protegidas existentes ou propostas (especialmente o refúgio de vida silvestre dos manguezais), o que abre possibilidade para a destruição de áreas importantes por idéias mirabolantes. Por exemplo, fazem mais de 10 anos que a unidade de conservação dos manguezais foi proposta, há verba de compensação ambiental da Cosipa e da Embraport e até agora nada. O ruim é que essa unidade de conservação, além da questão da biodiversidade, recursos pesqueiros, etc, também serviria como instrumento para nortear e racionalizar o uso do solo.

Devo ainda mencionar que as ocupações ilegais de áreas sensíveis na região do Pólo, que afetam manguezais e as encostas, são muitas vezes alimentadas por políticos populistas que se beneficiam do esquema. No entanto, acredito que a destruição de áreas de APP (área de preservação permanente), seja por falta de fiscalização ou por interesse público, não condizem com a realidade ambiental do Município. 
Em minha opinião, é realmente necessário um controle de ocupações de áreas de preservação permanente, evitando, por exemplo, um aumento da poluição por efluentes domésticos em áreas protegidas.

\section{IDÉIA CENTRAL D}

\section{INTERESSES POLÍTICOS, PESSOAIS OU IDEOLÓGICOS EM DETRIMENTO DO DESENVOLVIMENTO SUSTENTÁVEL}

\section{DSC}

Muitas vezes, interesses pessoais, políticos ou ideológicos são colocados em frente dos sociais, ambientais e econômicos. Eu considero isto uma grande ameaça à atual gestão ambiental de Cubatão.

Ações isoladas, entendimentos individualizados e interesses tendenciosos, podem certamente mascarar e prejudicar os avanços que estão sendo consolidados ao longo de anos de trabalho. Muitos atores realmente permanecem no campo político e não evoluem de forma efetiva na melhoria ambiental de Cubatão. Um bom exemplo são as ONGs com interesses individuais e não coletivos.

\section{IDÉIA CENTRAL E}

\section{POUCO INVESTIMENTO EM EDUCAÇÃO AMBIENTAL.}

\section{DSC}

Uma ameaça ao atual sistema vem a ser a falta de conhecimento $e$ esclarecimento por parte da comunidade sobre os agentes poluidores. Falta orientação, cursos e palestras, à população, estudantes, trabalhadores $e$ técnicos, quanto à emissão, controle e combate a poluição, em especial aos de maior risco à pessoa humana, e a necessidade da preservação do meio ambiente, para o futuro da humanidade.

Ao mesmo tempo, falta oportunidade de crescimento educacional e ocupação para valorização da população em idade ativa, pois o baixo nível de formação $e$ as desigualdades materiais em Cubatão fazem com que grande parcela da população não consiga atingir sequer o mínimo existencial necessário para a realização do princípio da dignidade da pessoa humana.

De outra parte, falta também divulgação de notícias na mídia incentivando as medidas pró-ativas.

\section{IDÉIA CENTRAL F}

\section{CRESCIMENTO DO PÓLO INDUSTRIAL DE CUBATÃO CONSIDERADO MAIS IMPORTANTE QUE O COMBATE À POLUIÇÃO}

DSC 
Uma grande ameaça à atual gestão ambiental seria um desenvolvimento baseado na economia, com expansão produtiva em áreas saturadas, sem cuidar dos possíveis efeitos e danos ao meio ambiente: o economicismo.

Hoje em dia certamente há uma crescente movimentação no sentido de se reiniciar um ciclo de grandes empreendimentos, de significativos impactos ambientais para a região, aumentando o transporte rodoviário na região, podendo ocasionar transtornos nas rodovias e infra-estruturas locais, bem como, possível aumento da poluição do ar.

Tanto o Pólo industrial quanto o setor de infra-estrutura, vem buscando o licenciamento de mais de 30 empreendimentos na $R M B S$, região que já teve sua capacidade suporte atingida. Projetos mirabolantes como os terminais portuários Barnabé-Bagres e a proposta de um porto na Ilha Piaçaguera, são alguns dos exemplos da pressão da FIESP e das próprias indústrias sobre o sistema de controle ambiental.

Se as empresas começarem a encarar o licenciamento ambiental como um entrave ao desenvolvimento nacional, haverá uma diminuição dos investimentos ambientais. $O$ que significaria um esmorecimento no cumprimento das metas estabelecidas na Agenda 21.

A mentalidade tacanha de dirigentes industriais que ainda são os mesmos da década de 80, não mudou. Eles ainda consideram a questão ambiental mera perfumaria e gasto inútil de dinheiro. Por exemplo, o setor empresarial, em minha opinião, muitas vezes influencia a qualidade e quantidade de informação ventilada à população. A divulgação é segmentada, direcionada e não raro falseada, no intuito de disseminar idéias de necessidade de crescimento a qualquer custo.

Além do mais, existe a ameaça de que o setor industrial resolva jogar todas as fichas na construção de um gerente para a cidade e desista de procurar alternativas na própria sociedade local. A tentação é grande, imagino, porém, devemos buscar alternativas que fujam a este figurino, ou seja, um tecnocrata que, apoiado nas indústrias, resolva assumir a gerência da cidade, sem qualquer intimidade com a sociedade local.

Neste mesmo aspecto, uma ameaça à atual gestão seria o desmonte da legislação protetiva de áreas de proteção ambiental, cuja flexibilização permitirá certamente o avanço de empreendimentos em fase de licenciamento sobre áreas protegidas e de especial importância ecológica.

\section{IDÉIA CENTRAL G}

\section{MÁ ADMINISTRAÇÃO E FALTA DE INVESTIMENTOS POR PARTE DO GOVERNO NA ÁREA AMBIENTAL}

DSC

Em meu entendimento uma ameaça à continuidade do processo de melhoria ambiental está centrada na falta de investimento por parte das autoridades governamentais na disponibilização e capacitação do corpo técnico responsável. Esta falta de investimento causa uma sobrecarga de serviço por 
falta de mão de obra e recursos do órgão ambiental. $O$ quadro de pessoal técnico do setor governamental vem sendo reduzido e fica cada vez menos experiente em face de uma demanda de projetos, resultando, entre outras coisas, numa demora na análise de processos ambientais.

A má administração financeira e falta de planejamento futuro também podem ser consideradas ameaças à atual gestão.

Neste mesmo aspecto, uma outra ameaça seria a inércia do Poder Público na implementação das medidas para correção dos pontos fracos da atual gestão.

Mudanças de governo também formam uma ameaça ao seguimento da atual gestão. Os programas de controle da poluição e da implantação de medidas preventivas podem ser afetados pelas mudanças nas políticas públicas em função de alterações político-partidárias.

O que falta mesmo é uma infra-estrutura moderna e atualizada e de apoio aos órgãos do Ministério Público, para atuação constante e permanente, nas áreas de preservação e controle do meio ambiente. Por exemplo, temos uma ameaça em Cubatão que é proveniente do passado que são os passivos ambientais, este trabalho terá que somar esforços das indústrias e órgãos ambientais para que se busquem a descontaminação destes passivos.

Outros problemas atuais que formam uma ameaça à atual gestão são: a proximidade ao colégio Afonso Schimit da Companhia Brasileira de Estireno que manipula diariamente toneladas de benzeno. $O$ benzoduto que liga a empresa à Refinaria Presidente Bernardes. E, até que haja uma pesquisa confiável, o deposito de sal grosso a céu aberto mantido pela Carbocloro e o Lixão de Pilões.

\section{IDÉIA CENTRAL H}

\section{RELACIONAMENTO PRECÁRIO ENTRE SETOR GOVERNAMENTAL, EMPRESARIAL E SOCIEDADE CIVIL, DIMINUINDO A POSSIBILIDADE DE DIÁLOGO}

DSC

Os atores governamentais, empresariais e sociais têm pouca experiência na negociação de acordos e conflitos nos assuntos que se relacionam ao desenvolvimento econômico e aspectos ambientais. Isto dificulta muito o diálogo.

\section{IDÉIA CENTRAL I}

\section{FALTA DE LEGISLAÇÃO ESPECÍFICA PARA A REGIÃO DO PÓLO INDUSTRIAL DE CUBATÃO}

\section{DSC}

A Legislação ambiental que vem sendo discutida a nível nacional, na sua maioria, não prevê situações que contemplem a peculiaridade da região. Os assuntos propostos nas leis consideram dados retirados de bibliografia elou 
estudos que cabem, talvez, para a maioria dos Estados e regiões, porém nos casos como o Pólo Industrial de Cubatão, devem ser previstas possibilidades de discussão de regras para a região. A falta desta abertura gera estudos ambientais excessivos, de alto custo e acabam prejudicando as avaliações por parte dos órgãos ambientais, que tem por critério adotar os padrões esclarecidos em lei.

Por outro lado, os problemas regionais que deveriam ser tratados de forma conjunta não o são, dando azo a que cada prefeitura, desconsiderando a característica metropolitana local, permaneça fechada a uma verdadeira discussão regional, privilegiando interesses privados em diversos setores.

Os principais aspectos apontados pelos participantes como ameaças à gestão atual, obtidos a partir do conteúdo dos discursos, separados por setor (setor governamental, empresarial e sociedade civil), conforme estabelecido na indagação, são apresentados sinteticamente abaixo:

\section{A. Setor governamental}

1) restrições ambientais impostas pela legislação, podendo causar a estagnação do crescimento do pólo industrial;

2) cumprimento da legislação ambiental brasileira somente no Estado de São Paulo;

3) falta de planejamento do desenvolvimento portuário e de logística para a região;

4) falta de visão adequada de desenvolvimento sustentável;

5) falta de continuidade e relaxamento das atividades de fiscalização e controle dos órgãos ambientais;

6) falta de infra-estrutura material e humana adequada para os órgãos de fiscalização e controle;

7) falta de investimentos na capacitação do corpo técnico responsável pelas ações de fiscalização e controle;

8) ausência de informações adequadas à população;

9) falta de planejamento adequado do uso do solo urbano, propiciando o crescimento desordenado e invasões de áreas públicas e ambientalmente protegidas; 
10) lentidão na implantação e falta de fiscalização de áreas protegidas;

11) falta de investimentos em educação em geral e em educação ambiental, em particular;

12) desmonte da legislação protetiva de áreas de especial importância ecológica;

13) má administração financeira e falta de planejamento a longo prazo;

14) falta de continuidade na implementação das políticas públicas, em razão das alterações político-partidárias de governo;

15) falta de legislação específica para a região, que considere as peculiaridades locais;

16) ausência de consideração da Baixada Santista como região metropolitana na discussão dos problemas regionais;

17) pouca experiência dos atores governamentais, empresariais e da sociedade civil na negociação visando à solução de conflitos relacionados ao desenvolvimento sustentável;

\section{B. Setor empresarial}

1) falta de visão adequada de desenvolvimento sustentável;

2) planejamento de crescimento do pólo industrial sem considerar os impactos ambientais e a capacidade de suporte dos ecossistemas, mas apenas o aspecto econômico;

3) disseminação à população de falsas idéias de necessidade de crescimento a qualquer custo;

4) visão da questão ambiental, inclusive do licenciamento, como entrave ao desenvolvimento nacional;

5) futuro gerenciamento da cidade por pessoa vinculada ao setor empresarial e desvinculada dos interesses da comunidade local;

6) pouca experiência dos atores governamentais, empresariais e da sociedade civil na negociação visando à solução de conflitos relacionados ao desenvolvimento sustentável; 


\section{Sociedade civil}

1) comodismo da população frente às questões ambientais;

2) interesses pessoais, políticos ou ideológicos colocados à frente do interesse público;

3) pouca experiência dos atores governamentais, empresariais e da sociedade civil na negociação visando à solução de conflitos relacionados ao desenvolvimento sustentável;

Os resultados quantitativos desse aspecto podem ser observados na Figura 15.

Figura 15- Distribuição das Idéias Centrais, segundo os participantes, frente à questão Ameaças, Cubatão, São Paulo, 2007.

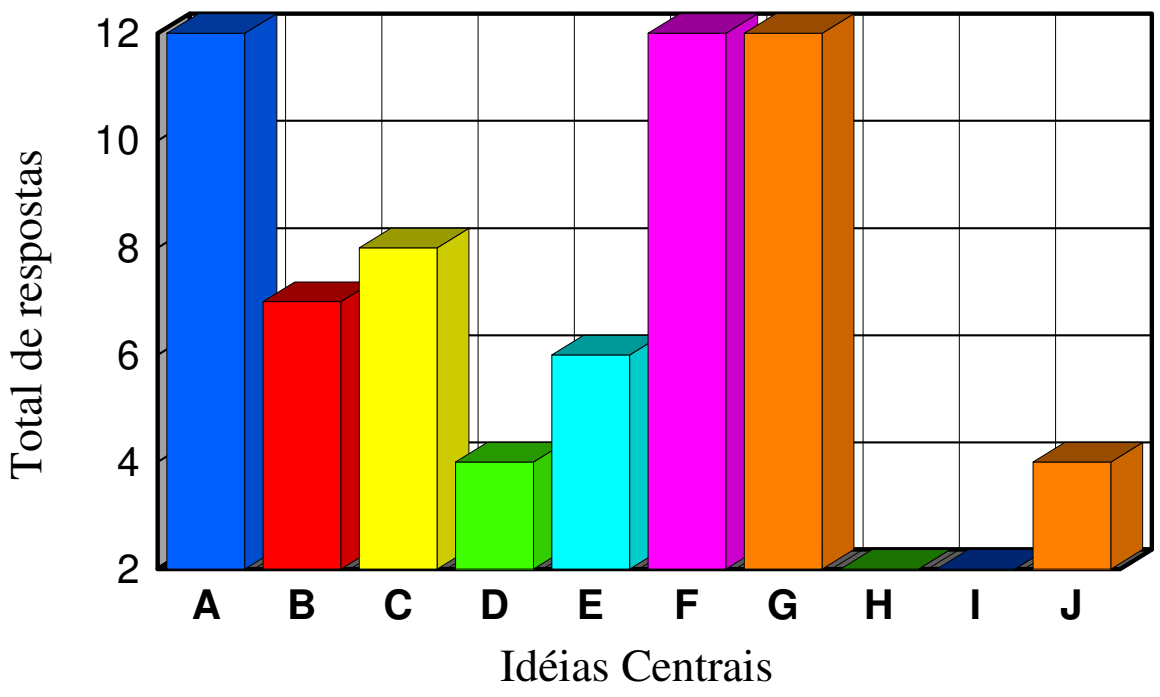

A-Crescimento industrial freado pela rigidez das medidas ambientais

B-Relaxamento por parte dos órgãos ambientais no controle e na fiscalização ambiental

C-Crescimento urbano desordenado e
F-Crescimento do pólo industrial de Cubatão considerado mais importante que o combate à poluição

G-Má administração e falta de investimentos por parte do governo na área ambiental

H-Relacionamento precário entre setor governamental, empresarial e sociedade civil, 


\begin{tabular}{|ll|l|}
\hline $\begin{array}{l}\text { ocupação de áreas protegidas } \\
\text { D-Interesses políticos, pessoais ou } \\
\begin{array}{l}\text { ideológicos em detrimento do } \\
\text { desenvolvimento sustentável }\end{array}\end{array}$ & $\begin{array}{l}\text { diminuindo a possibilidade de diálogo } \\
\text { I-Falta de legislação específica para a região do } \\
\text { Pólo Industrial de Cubatão } \\
\text { E-Pouco investimento em educação ambiental }\end{array}$ & \\
\end{tabular}

Avaliando o resultado quantitativo das respostas, a partir de cálculo percentual, considerando o total de respostas obtidas para a pergunta (69 respostas), nota-se que três foram os principais aspectos apontados pelos participantes como ameaças à atual gestão ambiental do pólo industrial de Cubatão, atingindo o mesmo percentual de escolha: crescimento industrial freado pela rigidez das medidas ambientais (A), crescimento do pólo industrial de Cubatão considerado mais importante que o combate à poluição $(\mathrm{F})$ e má administração e falta de investimentos por parte do governo na área ambiental $(\mathrm{G})$. Os dois aspectos mais apontados na seqüência dizem respeito ao crescimento urbano desordenado e ocupação de áreas protegidas (C), seguido do relaxamento por parte dos órgãos ambientais no controle e na fiscalização ambiental (B).

Pode-se verificar, ainda, somando-se as idéias centrais F, G, B, E e I dos discursos do sujeito coletivo resultantes da pesquisa, que o principal aspecto apontado pelos participantes como ameaça à atual gestão ambiental do pólo industrial de Cubatão diz respeito à gestão desenvolvida pelo setor governamental, considerada inadequada e ineficiente em vários aspectos, tais como no que se refere à legislação, à falta de investimentos e às ações de controle e fiscalização atualmente desenvolvidas no município.

Da mesma forma, no que se refere às oportunidades à gestão ambiental do pólo industrial de Cubatão, foi possível identificar 09 (nove) idéias centrais. No Quadro 22 são apresentadas as idéias centrais identificadas e, na sequiência, cada uma das idéias centrais e os respectivos discursos do sujeito coletivo. 
Quadro 22 - Idéias centrais quanto à questão Oportunidades

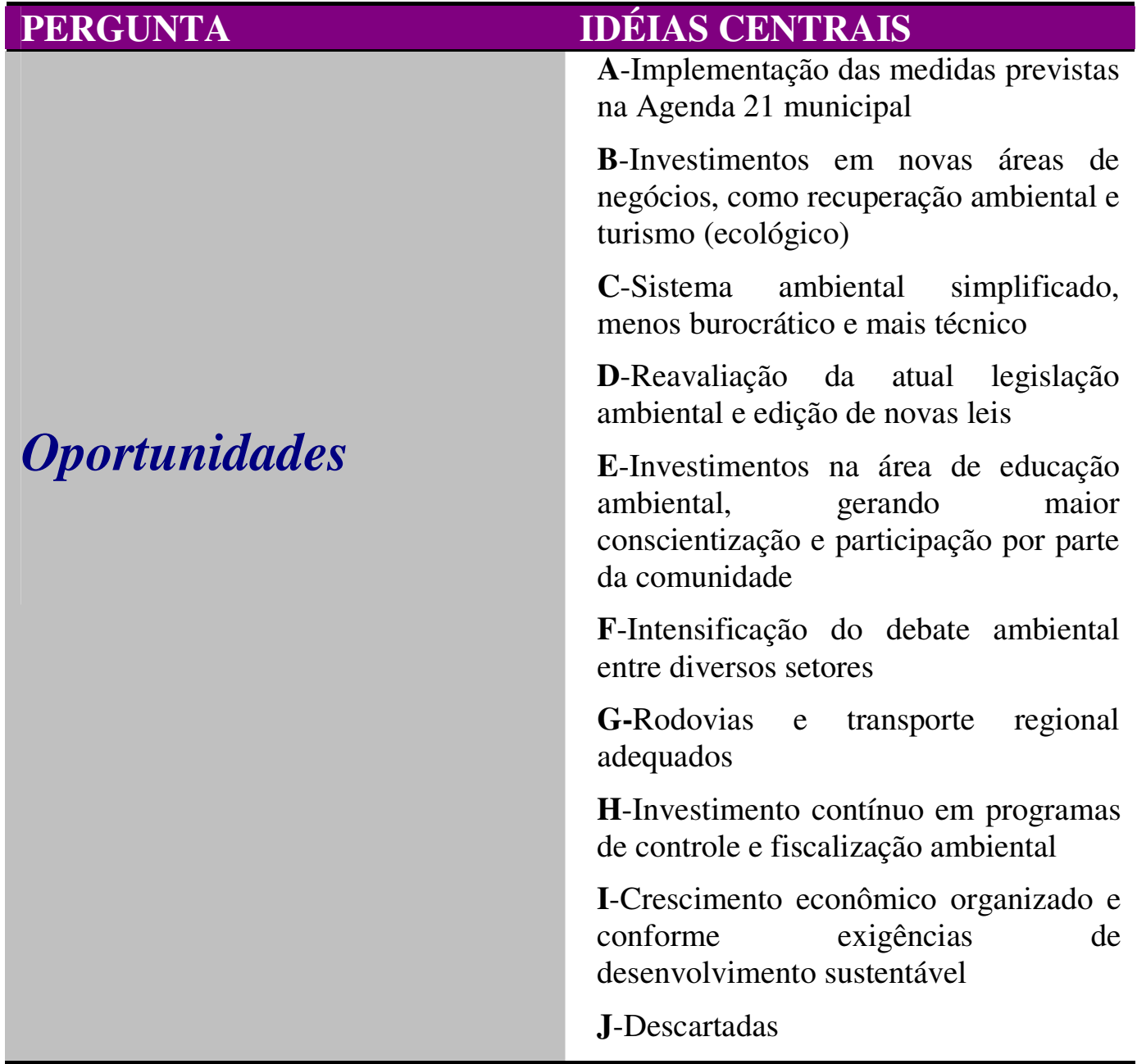

IDÉIA CENTRAL A

IMPLEMENTAÇÃO DAS MEDIDAS PREVISTAS NA AGENDA 21 MUNICIPAL 


\section{DSC}

Uma oportunidade para a atual gestão ambiental deve ser o aproveitamento da Agenda 21, como ferramenta de desenvolvimento sustentável, unindo os poderes públicos e privados.

A Agenda 21 foi elaborada pelos representantes de três setores, visando uma Cubatão melhor em 2020. O projeto estabeleceu diversas medidas e muitas delas estão voltadas para as questões ambientais, que foram identificadas pelos próprios participantes como assuntos relevantes a serem discutidos $e$ trabalhados.

Através da Agenda 21 pode-se elaborar um planejamento de todo o município, de forma a promover o desenvolvimento de todos os segmentos dentro do conceito da sustentabilidade.

Portanto, deve-se exigir o cumprimento das metas estabelecidas na Agenda 21, tornando Cubatão uma cidade modelo baseada em um sistema integrado de gestão. Definindo-se responsabilidade e indicadores de acompanhamento e monitoramento entre indústrias, setor público e comunidade.

\section{IDÉIA CENTRAL B}

\section{INVESTIMENTOS EM NOVAS ÁREAS DE NEGÓCIOS, COMO RECUPERAÇÃO AMBIENTAL E TURISMO (ECOLÓGICO)}

\section{DSC}

Acredito que no futuro Cubatão pode chegar a ser um pólo turístico, aproveitando de maneira racional o enorme potencial do Parque Estadual da Serra do Mar. O turismo ecológico significaria nada menos do que a recuperação da imagem de Cubatão através da transformação de Vale da Morte em cidade da ecologia.

Neste mesmo sentido, a recuperação ambiental traz em seu bojo, novas oportunidades de emprego, dando oportunidade a novos negócios relacionados à satisfação das exigências ambientais pelas indústrias.

Cabe também à sociedade civil estabelecer parceria público-privada que permita o desenvolvimento de atividades econômicas diferenciadas.

Cubatão ainda tem muito a se desenvolver ecologicamente. Com certeza será um dos grandes pólos atrativos de investimentos ambientais e industriais para a geração de empregos e estudos ambientais, por se tratar de um local de diversas espécies tais como o Guará Vermelho que hoje é visto como o símbolo de Cubatão no equilíbrio ecológico entre o ser vivo e o desenvolvimento industrial.

Cubatão é um laboratório gigantesco, onde podem ser realizadas pesquisas sobre as conseqüências da poluição industrial em tempo real, obviamente sem o sensacionalismo que a imprensa de hoje transforma as mais banais das notícias. Acredito que no futuro, Cubatão poderá ser visto como um "Benchmark" para o mundo em relação à recuperação de áreas contaminadas.

\section{IDÉIA CENTRAL C}




\section{SISTEMA AMBIENTAL SIMPLIFICADO, MENOS BUROCRÁTICO E MAIS TÉCNICO}

\section{DSC}

A atual gestão ambiental da região de Cubatão será beneficiada com a simplificação nos processos de licenciamento. Muitas vezes o excesso de exigências de estudos, emperra o andamento dos licenciamentos por falta de avaliação técnica da Cetesb.

Os órgãos governamentais devem simplificar os processos ambientais, buscando um tratamento mais técnico e menos burocrático. Este desenvolvimento técnico pode ser feito usando o CEPEMA. Seria bom se conseguíssemos formar especialistas a nível internacional.

Importante aspecto há de ser a especialização técnica nas áreas de manuseio e de controle ambiental, tanto aos órgãos de controle, de trabalhadores, de estudantes, dos órgãos públicos e da iniciativa privada, na atualização de tecnologias modernas e atuais. Isso com certeza melhoraria a qualidade de vida da população, trazendo melhores condições de trabalho e de remuneração.

Devemos portanto aprimorar as exigências e suas aplicabilidades de forma técnica e efetiva.

\section{IDÉIA CENTRAL D}

\section{REAVALIAÇÃO DA ATUAL LEGISLAÇÃO AMBIENTAL E EDIÇÃO DE NOVAS LEIS}

\section{DSC}

Acredito que podemos classificar como uma oportunidade a reavaliação da atual legislação ambiental. O governo deveria reavaliar as legislações tornando-as menos susceptiveis a interferências indevidas e reduzindo a burocracia.

Seria importante a criação de leis específicas, obrigando as empresas a terem uma estrutura mínima de pessoal qualificado na área ambiental, podendo este efetivo variar de acordo com o potencial poluidor de cada empreendimento.

Cabe também ao governo a implantação de novas leis de zoneamento e de planejamento do crescimento demográfico.

Neste mesmo aspecto, a regulamentação do art. 23 da CF trará uma definição de quem faz o quê. Em contrapartida, pergunto: como aparelhar os municípios para realizar a gestão dos processos de licenciamento?

Finalizando, acho que o grande salto poderá ser dado com o aparelhamento dos estados, e talvez com a promulgação de uma "Constituição Ambiental" voltada ao desenvolvimento sustentável, isso é, se é o queremos.

\section{IDÉIA CENTRAL E}




\title{
INVESTIMENTOS NA ÁREA DE EDUCAÇÃO AMBIENTAL, GERANDO MAIOR CONSCIENTIZAÇÃO E PARTICIPAÇÃO POR PARTE DA COMUNIDADE
}

\begin{abstract}
DSC
A política de combate e controle da poluição necessita acima de tudo de investimentos na área de educação ambiental que, sem sombra de dúvidas, garantirão, especialmente aos atuais jovens e crianças, bem como às gerações futuras, a oportunidade de conhecer a realidade passada, permitindo através desse conhecimento a conscientização de um meio ambiente ecologicamente equilibrado, tornando todos permanentes vigilantes ambientais.
\end{abstract}

Importante será a elaboração de programas de educação ambiental para que a sociedade civil possa contribuir com a melhoria no que diz respeito a sua atuação como cidadã.

Também devem ser desenvolvidas ações de aplicação da educação ambiental nos segmentos das indústrias e em instituições de ensino público e privado, enfim a todos os interessados.

No aspecto de participação, acredito que a sociedade civil deve assumir uma posição preventiva e "pró-ativa", para influir nos processos industriais e nos organismos de controle. Devemos capacitar a sociedade civil para uma efetiva cobrança de melhorias na área ambiental. A sociedade civil, mais capacitada, pode vir a criar programas para agregar informação $e$ conhecimento às comunidades.

Por sua vez, o setor governamental precisa adotar uma política de conscientização que informe a população sobre os prejuízos ambientais, sociais e econômicos causados pela dispersão urbana. Importante seria a criação de programas de comunicação de riscos na região e a reativação do programa APELL/UNEP (preparação e alerta da comunidade para emergências locais).

Além do que, o setor empresarial deve ampliar suas atividades com qualidade ambiental, agregando crescimento educacional da sociedade.

Por fim, acredito que devemos investir na comunidade: o cubatense ama Cubatão.

\section{IDÉIA CENTRAL F}

\section{INTENSIFICAÇÃO DO DEBATE AMBIENTAL ENTRE DIVERSOS SETORES}

\section{DSC}

Talvez possamos classificar como oportunidade a possibilidade de utilizar este momento para ampliar a discussão acerca do que se pretende para a $R M B S$, para que as pessoas passem a carregar consigo a variável ambiental e se apropriar de conhecimentos importantes para se atingir um bom nível de intelecção. Acredito que devemos ampliar o debate, buscando um 
desenvolvimento humano realmente sustentável, onde o meio ambiente seja valorizado pela sua conservação, e o homem pelo seu trabalho.

Podemos ampliar a participação da sociedade, através de fóruns locais com representantes da sociedade civil, do governo e das empresas, para discutir as questões ambientais, compartilhando decisões e responsabilidades. As empresas, por sua parte, devem utilizar mais o CIESP para integração entre empresas do Pólo de Cubatão, Ministério Publico e órgãos ambientais.

Seria interessante aproveitar a discussão em audiência pública do novo Plano Diretor do Município e estabelecer a vontade da sociedade em preservar o meio ambiente.

Talvez seja possível a formação de grupos tripartites de discussão local das questões ambientais.

\section{IDÉIA CENTRAL G}

\section{RODOVIAS E TRANSPORTE REGIONAL ADEQUADOS}

\section{DSC}

Uma oportunidade seria o desenvolvimento de um sistema de transporte adequado. Com rodovias de fácil acesso e boa conservação, permitindo um rápido escoamento da produção.

Acredito que o desenvolvimento de pátios de caminhões e cargas que se dirigem ao Porto de Santos, margens direita e esquerda, deve aumentar a acessibilidade do Pólo Industrial.

Devemos também investir em transportes coletivos que sejam eficientes, confortáveis e limpos.

\section{IDÉIA CENTRAL H}

\section{INVESTIMENTO CONTÍNUO EM PROGRAMAS DE CONTROLE E FISCALIZAÇÃO AMBIENTAL}

\section{DSC}

Uma oportunidade futura há de ser a efetivação de um planejamento global para as ações de controle ambiental, integrando efetivamente controle, avaliação de efeitos e recuperação ambiental. Com isso, o setor governamental reconstruirá o cenário de crescimento sustentável da região, pois estará intensificando suas ações preventivas.

Neste mesmo aspecto, outra oportunidade seria a implantação do SEAT, Social and Economics Assesment Toolbox, que é uma ferramenta desenvolvida por um grupo anglo americano para avaliar as necessidades de comunidades ao redor do mundo, sendo que existe a idéia de se estender essa ferramenta para as demais empresas do Pólo Industrial de Cubatão.

Acredito também que, com a mudança do governo no próximo ano, poderão ser introduzidas novas metas, possibilitando a contribuição de oportunidades para melhor desenvolvimento das ações ambientais como um todo. 
Uma delas pode ser, por exemplo, o encerramento das ações da Serra do Mar e Lixões de Pilões, bem como, a inauguração do CEPEMA. Estas ações demonstrarão uma nova perspectiva para Cubatão na área ambiental.

Podem também ser desenvolvidos programas de mitigação de impactos ambientais e remediação junto às empresas.

\section{IDÉIA CENTRAL I}

\section{CRESCIMENTO ECONÔMICO ORGANIZADO E CONFORME EXIGÊNCIAS DE DESENVOLVIMENTO SUSTENTÁVEL}

\section{DSC}

A atual gestão ambiental deve considerar como uma oportunidade o desenvolvimento das empresas do Pólo conforme requisitos de desenvolvimento sustentável. Assim, o setor empresarial seria obrigado a melhorar o desempenho econômico pela adoção de novas tecnologias sustentáveis e de geração mínima de rejeitos. $O$ que geraria um crescimento com apoio geral e amplo, do governo, empresa e da comunidade.

Para gerar um crescimento ecologicamente sustentável, o setor empresarial pode elaborar um TAC referente à ação envolvendo as 23 indústrias do Pólo Industrial.

Além disso, compensações ambientais podem viabilizar ações que não ocorreriam se dependessem apenas da boa vontade dos industriais ou do governo. Cada novo empreendimento, ou acidente industrial, é uma oportunidade.

O governo pode pensar em criar uma campanha de incentivo às empresas que mais investem nas questões ambientais, criando programas de melhorias contínuas, os selos verdes. Por exemplo, as empresas podem ser obrigadas a realizar eventos periódicos voltados à apresentação de seus planejamentos, suas ações ambientais, dos avanços e das dificuldades. A própria FIESP poderia organizar a realização desses eventos. Ao longo de cada ano, todas as indústrias deveriam expor seus trabalhos e preocupações.

O que também pode ter êxito são incentivos fiscais para ações em pro ao meio ambiente. Além disso, o governo poderia decidir ampliar o prazo de renovação de licenças ambientais, que estão atrelados a um processo de crescimento econômico com a melhoria contínua da gestão ambiental de Cubatão. 
Os principais aspectos apontados pelos participantes como oportunidades à gestão atual, obtidos a partir do conteúdo dos discursos, separados por setor (setor governamental, empresarial e sociedade civil), conforme estabelecido na indagação, são apresentados sinteticamente abaixo:

\section{A. Setor governamental}

1) aproveitamento da Agenda 21 local no planejamento do desenvolvimento sustentável e definição de indicadores de sua implementação;

2) desenvolvimento de pesquisas e estudos sobre os aspectos ambientais do município;

3) simplificação dos procedimentos de licenciamento ambiental, com tratamento mais técnico e menos burocrático;

4) especialização técnica dos órgãos públicos ambientais;

5) investimento em políticas públicas de educação ambiental, inclusive do setor industrial;

6) revisão da legislação ambiental, visando dar proteção efetiva ao meio ambiente;

7) implantação de novas leis de zoneamento e de planejamento do crescimento demográfico;

8) melhoria do sistema de transportes da região, inclusive do transporte público de passageiros;

9) planejamento global da gestão ambiental, privilegiando ações preventivas;

10) criação de instrumentos econômicos para a gestão ambiental;

11) ampliação e intensificação do debate sobre o meio ambiente e o desenvolvimento sustentável entre os setores governamental, empresarial e sociedade civil.

\section{B. Setor empresarial}


1) aproveitamento da Agenda 21 municipal no planejamento do desenvolvimento sustentável e definição de indicadores de sua implementação;

2) investimentos em turismo ecológico;

3) investimentos em negócios relacionados à recuperação ambiental do município;

4) desenvolvimento de pesquisas e estudos sobre os aspectos ambientais do município;

5) especialização técnica e educação ambiental do setor;

6) gestão segundo as exigências do desenvolvimento sustentável, com melhoria do desempenho econômico das empresas e apoio público;

7) ampliação e intensificação do debate sobre o meio ambiente e o desenvolvimento sustentável entre os setores governamental, empresarial e sociedade civil.

\section{Sociedade civil}

1) definição de indicadores de implementação da Agenda 21 municipal;

2) geração de empregos por novas áreas de negócios, como recuperação ambiental e turismo ecológico;

3) capacitação da sociedade civil para a participação nos processos de tomada de decisões e na disseminação do conhecimento;

4) ações viabilizadas pelas compensações ambientais;

5) ampliação e intensificação do debate sobre o meio ambiente e o desenvolvimento sustentável entre os setores governamental, empresarial e sociedade civil.

Na Figura 16 pode-se observar os resultados quantitativos desse aspecto. 
Figura 16 - Distribuição das Idéias Centrais, segundo os participantes, frente à questão Oportunidades, Cubatão, São Paulo, 2007.

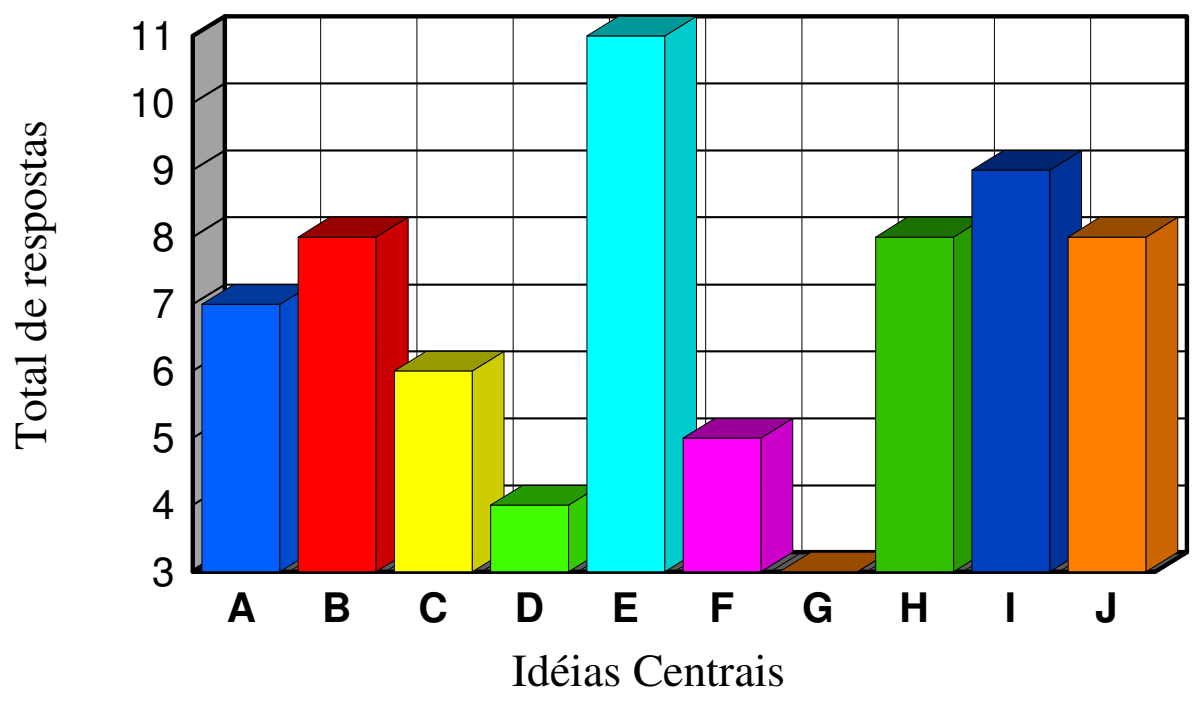

A-Implementação das medidas previstas na Agenda 21 municipal

B-Investimentos em novas áreas de negócios, como recuperação ambiental e turismo (ecológico)

C-Sistema ambiental simplificado, menos burocrático e mais técnico

D-Reavaliação da atual legislação ambiental e edição de novas leis

E-Investimentos na área de educação ambiental, gerando maior conscientização e participação por parte da comunidade
F-Intensificação do debate ambiental entre diversos setores

G-Rodovias e transporte regional adequados

H-Investimento contínuo em programas de controle e fiscalização ambiental

I-Crescimento econômico organizado e conforme exigências de desenvolvimento sustentável

J-Descartada 
Analisando o resultado quantitativo das respostas, a partir de cálculo percentual, considerando o total de respostas obtidas para a pergunta (69 respostas), verifica-se que investimentos na área de educação ambiental, gerando maior conscientização e participação por parte da comunidade, é visto pelos participantes como a melhor oportunidade à atual gestão ambiental do pólo industrial de Cubatão (E). $\mathrm{O}$ aspecto mais apontado, na seqüência, refere-se à oportunidade de crescimento econômico organizado e conforme exigências de desenvolvimento sustentável (I). Atingindo o mesmo percentual de escolha, são vistos como boas oportunidades, ainda, os investimentos em novas áreas de negócios, como recuperação ambiental e turismo ecológico (B), e o investimento contínuo em programas de controle e fiscalização ambiental $(\mathrm{H})$.

Somando-se as idéias centrais mais votadas, nota-se que, segundo os participantes, as melhores oportunidades à atual gestão ambiental do pólo industrial de Cubatão dizem respeito à efetiva promoção do desenvolvimento sustentável no município.

Pode-se observar algumas aparentes contradições entre alguns dos discursos do sujeito coletivo produzidos quanto aos diversos aspectos postos na indagação, verificando-se dos resultados obtidos que aspectos tidos como pontos fracos para alguns são vistos como pontos fortes para outros.

Essa aparente contradição pode ser solucionada, ao menos parcialmente, pela avaliação dos resultados qualitativos em conjunto com os resultados quantitativos.

Quanto aos pontos fracos e pontos fortes, considerando-se não apenas o percentual de respostas obtidas, mas também que, quanto aos pontos fracos o cálculo foi efetuado sobre uma amostra maior, nota-se que prevalece a visão negativa quanto aos pontos conflitantes, conforme demonstrado abaixo:

1) A deficiência no controle e fiscalização por parte dos órgãos ambientais é apontada como ponto fraco da gestão atual por 20,20\% das respostas (Idéia central H), enquanto sua intensificação é apontada como ponto forte por 10,98\% das respostas (Idéia central E);

2) A falta de integração entre os setores governamental, empresarial e sociedade civil é apontada por 10,10\% das respostas (Idéia central I), enquanto a existência de forte integração é apontada por 8,54\% das respostas (Idéia central G); 
3) A legislação é apontada como insuficiente, inadequada e desatualizada em $15,15 \%$ das respostas (Idéias centrais B e C) e suficiente por apenas 1,22\% das respostas (Idéia central I);

4) A falta de investimentos em educação ambiental da população é apontada por $12,12 \%$ das respostas (Idéia central F), enquanto sua existência por apenas 2,44\% (Idéia central C);

5) A participação da sociedade civil é apontada como deficiente por 13,13\% das respostas (Idéia central J), sendo vista como mais organizada e participativa por 12,20\% das respostas (Idéia central D).

De uma maneira geral, o discurso do sujeito coletivo produzido em resposta à questão vem de encontro ao conceito de desenvolvimento sustentável adotado como referencial teórico deste trabalho, fundamentado na harmonização de objetivos sociais, ambientais e econômicos.

O discurso do sujeito coletivo no que se refere aos pontos fortes e fracos da atual gestão ambiental do pólo industrial de Cubatão ressalta a necessidade de planejamento de longo prazo, com a criação e implementação de políticas públicas ambientais que prevejam ações efetivas e integradas com os demais aspectos do desenvolvimento sustentável, inclusive com maior utilização de instrumentos econômicos.

Apesar de mencionar a necessidade de maiores incentivos às empresas para a adoção de práticas ambientais adequadas, o discurso enfatiza a importância da continuidade do processo de fiscalização e controle por meio de instituições públicas bem estruturadas, capacitadas, eficientes e fortes, cujas ações sejam respaldadas por uma legislação adequada e eficiente.

Ainda segundo o discurso do sujeito coletivo obtido, é necessário que tanto o setor governamental quanto o setor empresarial atuem a partir de uma visão holística da questão ambiental, por meio de ações pró-ativas e não apenas em reação à legislação ou ações pontuais de órgãos públicos, bem como que essa atuação seja mais integrada, inclusive com a sociedade civil.

Nesse processo de gestão, o discurso evidencia, também, a necessidade de promoção da educação ambiental da sociedade em geral, bem como de disponibilização de informação adequada à população e capacitação desta para 
participar do processo de tomada de decisões e, portanto, da própria elaboração das políticas públicas, por meio da criação de instrumentos adequados para essa participação.

Esse resultado confirma, portanto, a importância da participação social no trato das questões ambientais e da existência de informação adequada para assegurar a efetividade dessa participação, conforme destacado na Agenda 21 Global, como necessárias à promoção do desenvolvimento sustentável (ver item 2.3.1.), uma vez que, participando do processo de elaboração das políticas públicas ambientais, a população fica mais consciente e comprometida com a sua implantação. E quanto maior for essa participação maior a possibilidade de mudança de comportamento das empresas no trato das questões ambientais, face à cobrança social de ações mais voltadas à sustentabilidade sócio-econômica-ambiental.

O discurso do sujeito coletivo, no que se refere às ameaças e oportunidades, vem complementar esse entendimento ao apontar como principais ameaças à atual gestão ambiental do pólo industrial de Cubatão a possibilidade de relaxamento no controle e fiscalização ambiental, inclusive de áreas protegidas, privilegiando-se o crescimento econômico de curto prazo, em detrimento do planejamento de longo prazo, tanto por parte do setor governamental quanto por parte do setor empresarial.

A falta de investimentos em educação ambiental e no fornecimento de infraestrutura adequada e capacitação dos órgãos ambientais representa, conforme o discurso produzido, outra importante ameaça à gestão ambiental adequada do pólo industrial.

A possibilidade de desmonte da legislação ambiental também é vista como forte ameaça, sendo decorrência, conforme o discurso, de outra ameaça, que é a visão equivocada da questão ambiental como entrave ao desenvolvimento do pólo e do país, tanto pelo setor empresarial, quanto governamental e sociedade civil, aliada a um certo comodismo por parte desta, que poderia decorrer da falta de informações suficientes e adequadas, ficando a população sujeita a receber informações distorcidas e oportunistas, aspectos também mencionados dentre as ameaças.

Resultado interessante apontado pelo discurso como ameaça à gestão do pólo industrial de Cubatão é a falta de planejamento do uso e ocupação do solo urbano, favorecendo o crescimento urbano desordenado, com ocupações em áreas 
ambientalmente protegidas, revelando a necessidade de ampliação da gestão ambiental para outros aspectos que vão além do controle específico da poluição.

A coerência do discurso do sujeito coletivo pode ser verificada analisando-se o resultado obtido no que se refere às oportunidades. Nota-se que o discurso enfatiza o desenvolvimento do município em consonância com as exigências do desenvolvimento sustentável como importante oportunidade da gestão atual, inclusive para a melhoria do desempenho econômico das empresas, atendendo, ainda, aos anseios do público.

Outra oportunidade mencionada diz respeito ao surgimento de novos ramos de negócios decorrentes de uma gestão ambiental adequada, seja pela necessidade de adoção de medidas de controle e de recuperação ambiental, seja pela valorização de características ambientais do município (turismo ecológico), contribuindo para a geração de empregos. São apontadas, também, como oportunidades à atual gestão, a realização de investimentos na capacitação técnica dos órgãos públicos, do setor empresarial e da sociedade civil, assim como em educação ambiental, inclusive para viabilizar a participação desta última nos processos de tomada de decisões e na disseminação do conhecimento.

Ainda são vistas como oportunidades, segundo o discurso do sujeito coletivo produzido, a ampliação e intensificação do debate sobre as questões ambientais entre todos os interessados e o aproveitamento da Agenda 21 local na implementação do desenvolvimento sustentável do município, com a definição de indicadores para avaliar essa implementação.

\subsection{INFORMAÇÕES SOBRE SISTEMAS DE GESTÃO AMBIENTAL NAS INDÚSTRIAS}

No Quadro 23 pode-se observar as informações sobre a existência de sistemas de gestão ambiental implementados, identificação dos sistemas e data de implementação, das 15 (quinze) empresas do pólo industrial de Cubatão que responderam ao formulário encaminhado. 
Quadro 23 - Sistemas de Gestão Ambiental nas Empresas do Pólo Industrial de Cubatão

\begin{tabular}{|l|c|}
\hline $\begin{array}{l}\text { Adoção de Sistemas de Gestão Ambiental pelas } \\
\text { Empresas do Pólo Industrial de Cubatão }\end{array}$ & \\
\hline Sistema de gestão ambiental (SGA) implementado & 13 \\
\hline Sistema ISO 14001 & 12 \\
\hline Programa de Atuação Responsável & 08 \\
\hline Sistema de gestão ambiental próprio & 04 \\
\hline ISO + Atuação responsável & 06 \\
\hline ISO + SGA próprio & 01 \\
\hline ISO + Atuação responsável + SGA próprio & 02 \\
\hline Não tem sistema de gestão ambiental & 02 \\
\hline
\end{tabular}

Quanto às datas de implementação dos sistemas de gestão ambiental, segundo as respostas das empresas, todas as certificações ISO 14001 foram obtidas a partir do ano de 1999 até o ano 2004. A adesão da maioria das empresas ao Programa de Atuação Responsável, por sua vez, se deu logo no início de sua adoção pela ABIQUIM, ou seja, nos anos de 1992 e 1993, enquanto que a adoção de SGAs próprios começou a ocorrer apenas em data recente, a partir do ano 2002.

Em geral, à exceção das empresas com adesão ao Programa de Atuação Responsável da ABIQUIM, pode-se verificar que as empresas do pólo industrial de Cubatão vêm buscando melhorar seu desempenho ambiental, pela adoção de sistemas de gestão específicos, somente nos últimos anos, em especial a partir de 1999. Verifica-se, assim, que a conscientização desse setor para a necessidade da inserção da variável ambiental no gerenciamento das empresas vem se intensificando em Cubatão, contribuindo para a melhoria da qualidade ambiental do município. $\mathrm{O}$ desenvolvimento de programas de responsabilidade sócio-ambiental por algumas indústrias de Cubatão vem crescendo nos últimos anos, conforme noticiado na mídia local e regional, revelando maior preocupação daquelas com os impactos que suas 
atividades causam no meio ambiente e na sociedade, constituindo um bom exemplo da conscientização do setor empresarial, com prováveis efeitos positivos sobre a qualidade de vida da população do município. Embora esse levantamento não tenha sido efetuado neste trabalho, dado aos seus limites, mereceria ser tratado em estudo específico. 


\section{CONCLUSÕES}

No que se refere ao objetivo geral deste trabalho, foram identificados resultados positivos no controle da poluição ambiental de Cubatão, do início da implementação do Programa até o ano de 2005, verificando-se que houve considerável redução das emissões globais de poluentes atmosféricos, com reflexos positivos na melhoria geral da qualidade do ar nas duas bacias aéreas do município (Cubatão-Centro e Cubatão-Vila Parisi), bem como melhoria geral da qualidade das águas dos três principais cursos d'água do município (Rios Cubatão, Mogi e Piaçaguera).

A evolução dos indicadores ambientais e sociais de Cubatão demonstra, entretanto, que ainda não está sendo garantida no município a sustentabilidade dos recursos naturais e a qualidade de vida exigidas pelo desenvolvimento sustentável.

Os indicadores ambientais demonstram que continuam ocorrendo ultrapassagens dos padrões de qualidade do ar, com registros de nível de atenção, nas duas bacias áreas, em especial em Cubatão-Vila Parisi, na qual os padrões de qualidade não são atendidos em pouco mais de $10 \%$ do tempo, situações nas quais são previstos efeitos nocivos à saúde da população e ao meio ambiente.

No que se refere ao controle da poluição das águas, foi constatado que, além de ter demorado um pouco mais a ocorrer, a qualidade das águas se encontra muito aquém do exigido para a proteção do meio ambiente no município, em especial nos Rios Mogi e Piaçaguera.

Não foi possível verificar a eventual evolução obtida quanto ao controle dos resíduos sólidos industriais face à ausência de informações sistematizadas sobre esse aspecto.

Cubatão continua a não exibir bons indicadores sociais, apresentando condições precárias de saneamento básico, com atendimento de apenas $35 \%$ dos domicílios por rede geral de esgoto sanitário, baixo nível de escolaridade e mais de $40 \%$ da população vivendo em favelas, em situação de vulnerabilidade alta ou muito alta, conforme classificação do IPVS-Índice Paulista de Vulnerabilidade Social.

A pouca melhoria verificada nas condições de vida da população se reflete, em alguns aspectos, nos indicadores ambientais, a exemplo do atendimento precário 
dos domicílios do município por rede geral de esgoto sanitário, com evidente repercussão na qualidade das águas, sendo possível concluir que aproximadamente $65 \%$ dos esgotos sanitários vêm tendo como destino final os cursos d'água do município e região, somado ao fato de mais de $40 \%$ da população viver em áreas de invasão e favelas, várias delas situadas em áreas de preservação permanente e em unidades de conservação, com restrições para a instalação de equipamentos públicos.

Enquanto isso, foi constatado que o PIB per capita do município de Cubatão vem aumentando gradativamente no período de 1999 a 2004, sendo cinco vezes superior ao PIB per capita do Estado de São Paulo no mesmo ano (2004).

Verificou-se, assim, da avaliação da evolução desses indicadores no período da pesquisa, que o desenvolvimento do município não vem sendo efetuado em bases sustentáveis, face à ausência de harmonia entre as dimensões econômica, ambiental e social. Nesse aspecto, restou confirmada a insuficiência do PIB per capita como indicador de desenvolvimento sustentável, conforme mencionado no item 2.3.4., por não ser capaz de capturar todos os aspectos importantes deste.

Os indicadores institucionais do município demonstram, por sua vez, a insuficiência de investimentos municipais na gestão ambiental, bem como a pouca preocupação do município com esse aspecto, confirmando a não inserção dos fundamentos da sustentabilidade no processo de desenvolvimento de Cubatão.

No que se refere à existência de instrumentos processuais adequados às ações relativas às causas ambientais, constatou-se que, a despeito da ação civil pública ser importante instrumento na tutela do meio ambiente, o surgimento do Termo de Compromisso de Ajustamento de Conduta facilitou essa tutela pelo Poder Público, sendo mais adequado à solução consensual dos conflitos ambientais, que vem aumentando como consequência da conscientização da sociedade como um todo sobre a necessidade do desenvolvimento sustentável.

Com relação ao objetivo específico relacionado à avaliação do papel desempenhado pelos diversos atores envolvidos na evolução do controle da poluição ambiental em Cubatão, foi identificada a forte atuação administrativa da CETESB como um dos principais fatores determinantes dessa evolução e conseqüente melhoria dos indicadores ambientais do município, em especial no início da implementação do Programa. 
Verificou-se, também, que foi fundamental nesse processo o apoio da sociedade civil às ações da CETESB, em especial da comunidade do município de Cubatão, possibilitando a obtenção dos resultados desejados.

A mídia, conforme verificado na pesquisa, também desempenhou papel fundamental no processo que levou à criação e implementação do Programa de Controle da Poluição Ambiental de Cubatão, ao tornar público o contexto de degradação ambiental do município e suas consequiências, chamando a atenção para o problema de tal maneira que era impossível ao Poder Público ignorar a situação e não tomar qualquer providência para encontrar uma solução.

Foi constatado que a atuação do Ministério Público em Cubatão passou a se intensificar a partir do ano de 1999, com maior utilização do instrumento do termo de compromisso de ajustamento de conduta na solução dos conflitos ambientais a partir do ano 2000, alguns deles formalizados em conjunto com a CETESB, desempenhando importante papel na evolução do controle da poluição no município. Embora seja pequeno o número de ações civis públicas na fase imediatamente posterior à vigência da lei respectiva, é inegável, ainda, a importância das primeiras ações propostas visando à responsabilização dos poluidores pelos danos causados ao meio ambiente, fato até então inédito na história brasileira, que, sem sombra de dúvidas, contribuiu para a melhoria da qualidade ambiental de Cubatão.

Quanto ao papel desempenhado pelas indústrias, verificou-se que sofreu modificação ao longo da implementação do Programa. Na fase inicial, as indústrias pouco contribuíram para a melhoria da qualidade ambiental do município, que somente foi obtida em face da atuação da CETESB, por meio das inúmeras autuações aplicadas, aliada às pressões da comunidade do município e da mídia, conforme acima mencionado, obrigando as indústrias a adequarem suas atividades à legislação vigente.

Não foi possível identificar o momento exato em que as indústrias passaram a contribuir por meio de uma conduta mais pró-ativa para a melhoria das condições ambientais do município, que, possivelmente, variou de uma empresa para outra. Foi constatado, porém, aumento da adoção de sistemas de gestão ambiental pelas indústrias que compõem o pólo industrial de Cubatão nos últimos anos, 
especialmente a partir do ano de 1999, demonstrando que a contribuição das indústrias nesse sentido vem aumentando gradativamente.

Os Poderes Executivo e Legislativo local tiveram menor importância nesse processo, sendo praticamente inexistentes informações sobre ações do Poder Executivo em prol da melhoria da qualidade ambiental do município, enquanto poucas são as ações registradas do Poder Legislativo.

De uma maneira geral, foi constatado que a CETESB e a sociedade civil foram os atores mais importantes na evolução do controle da poluição em Cubatão, contribuindo para o avanço desse processo a atuação do Ministério Público do Estado de São Paulo e, em data mais recente, uma conduta mais pró-ativa das indústrias.

O objetivo de obtenção da visão desses atores sobre os principais fatores determinantes da evolução do controle da poluição no município foi alcançado pelo questionário aplicado, verificando-se que essa visão está em sintonia com os resultados acima mencionados sobre o papel desempenhado pelos diversos setores envolvidos nesse processo.

Segundo os participantes da pesquisa, os fatores "Pressão da mídia", "Autuações da CETESB”, "Conscientização Ambiental dos dirigentes das Indústrias" "Ações Civis Públicas movidas pelo Ministério Público" e "Pressão da Comunidade do Município de Cubatão" foram os principais determinantes da evolução do controle da poluição em Cubatão. A visão dos participantes da pesquisa sobre as atuações do Poder Executivo e do Poder Legislativo do município, que estão dentre os seis fatores menos votados, por sua vez, confirma a pouca importância desses setores nessa evolução.

Com relação ao objetivo de identificação dos principais instrumentos utilizados no processo de melhoria das condições do meio ambiente no município, o Programa de Controle da Poluição Ambiental estabelecido pelo governo do Estado de São Paulo em 1983, que encarregou a CETESB de sua execução, foi identificado como o principal instrumento utilizado, consistindo numa experiência de aplicação de política pública ambiental bem sucedida e, portanto, da maior relevância, podendo servir como parâmetro para situações semelhantes, que exijam tratamento emergencial. 
Não foi possível identificar a influência direta da promulgação da Constituição Federal, em 1988, ou da edição da Lei de Ação Civil Pública, em 1985 nesse caso por meio das ações civis públicas propostas no município - na melhoria da qualidade ambiental de Cubatão, visto que o número de ações propostas manteve-se equilibrado ao longo de todo o período da pesquisa.

Também não foi possível comprovar a efetiva influência dos Termos de Ajustamento de Conduta na melhoria da qualidade ambiental do município, especialmente pelo fato da maioria dos termos terem sido formalizados em datas recentes, abrangendo principalmente os cinco últimos anos deste estudo.

Pode-se concluir, entretanto, que a existência de uma base legal consistente é vital para a implementação de políticas públicas ambientais no país, e não foi diferente nesse caso, sendo fundamental para o sucesso da implementação do Programa de Controle da Poluição Ambiental em Cubatão. Essa base legal foi dada, no início do Programa, pela Lei da Política Nacional de Meio Ambiente, aprovada dois anos antes da criação daquele. A edição da Lei de Ação Civil Pública, em 1985, propiciando um instrumento processual adequado às ações relativas a causas ambientais, aliada à promulgação da Constituição Federal, em 1988, abrindo espaço jurídico e institucional para uma ação cada vez mais intensa do Estado na elaboração e implementação de políticas públicas ambientais, contribuiu, sem sombra de dúvidas, para o fortalecimento da ação da CETESB em Cubatão.

Quanto à Lei dos Crimes Ambientais, que entrou em vigor no ano de 1998, embora também não tenha sido possível identificar sua influência direta sobre a evolução dos indicadores ambientais do município, foi constatado, por meio dos indicadores institucionais relacionados à atuação do Ministério Público do Estado de São Paulo que, a partir da vigência da norma, aumentou consideravelmente o número de termos de compromisso de ajustamento de conduta obtidos, sendo que quatro deles tiveram como objeto a regularização de fontes autuadas em 1984 pelo órgão ambiental.

Conforme constatado neste estudo, o aumento na solução consensual dos conflitos ambientais, por meio do instrumento do termo de compromisso de ajustamento de conduta, coincide com o período em que a maioria das empresas que prestaram informações implementaram sistemas de gestão ambiental. Pode-se 
concluir, assim, que os sistemas de gestão ambiental são importantes instrumentos para a melhoria do desempenho ambiental das empresas, bem como para a conscientização destas corporações e de seus membros, contribuindo, consequentemente, para propiciar a melhoria da qualidade ambiental em geral.

No que se refere ao objetivo de avaliação da suficiência e adequação do sistema de informações existente para a correta avaliação da gestão ambiental de Cubatão, foi constatada sua insuficiência e inadequação, diante das dificuldades encontradas na pesquisa para a seleção dos indicadores de desenvolvimento sustentável que seriam utilizados, tanto face à ausência de informações sistematizadas sobre diversos aspectos relevantes, quanto pela inadequação de algumas informações disponíveis à sociedade.

Foi verificado, também, que o município de Cubatão não possui informações sistematizadas, na forma de indicadores, sobre quaisquer dos temas considerados relevantes na promoção do desenvolvimento sustentável.

\section{Foram propostos alguns indicadores considerados}

\section{relevantes para o município:}

1) geração de resíduos sólidos industriais em tonelada/ano;

2) \% de resíduos industriais perigosos sobre o total gerado;

3) \% dos resíduos industriais destinados à reciclagem/reaproveitamento sobre o total gerado;

4) \% da área contaminada sobre o total da área do município;

5) perda de floresta primária sobre o total de floresta primária remanescente;

6) total de florestas recuperadas;

7) total de áreas protegidas sobre o total da área do município;

8) \% de coleta seletiva de lixo sobre o total de lixo coletado;

9) gastos com pesquisa e desenvolvimento (P\&D);

10) \% da população vivendo em áreas de invasões e favelas sobre o total da população do município; 
11) \% de áreas protegidas ocupadas por invasões e favelas em relação ao total da área urbana;

12) taxa de desemprego;

13) relação escolaridade-desemprego;

14) incidência de doenças relacionadas ao saneamento ambiental inadequado;

15) \% do gasto público com proteção do meio ambiente no total do orçamento do município;

16) existência de leis municipais específicas para proteção do meio ambiente;

17) existência de Conselho Municipal do Meio Ambiente em atividade;

Quanto ao objetivo de identificar a visão da coletividade sobre a gestão ambiental do pólo industrial de Cubatão desenvolvida nos anos mais recentes do período da pesquisa e obter eventuais propostas de melhoria, o discurso do sujeito coletivo produzido em resposta à questão formulada vem de encontro ao conceito de desenvolvimento sustentável adotado como referencial teórico deste trabalho, fundamentado na harmonização de objetivos sociais, ambientais e econômicos.

Verificou-se, assim, que o discurso do sujeito coletivo produzido no que se refere aos pontos fortes e fracos da atual gestão ambiental do pólo industrial de Cubatão ressalta a necessidade de planejamento de longo prazo, com a criação e implementação de políticas públicas ambientais que prevejam ações efetivas e integradas com os demais aspectos do desenvolvimento sustentável, inclusive com maior utilização de instrumentos econômicos, sem prejuízo da continuidade do processo de fiscalização e controle por meio de instituições públicas bem estruturadas, capacitadas, eficientes e fortes, cujas ações sejam respaldadas por uma legislação adequada e eficiente.

Foi constatado, ainda, que segundo a visão da coletividade participante, no processo de gestão é necessário a adoção de uma visão holística da questão ambiental, bem como que aquela se faça por meio de ações pró-ativas e mais integradas entre todos os interessados, inclusive com a sociedade civil. O discurso destaca, também, a necessidade de promoção da educação ambiental da sociedade em geral, bem como de disponibilização de informação adequada à população e capacitação desta para participar do processo de tomada de decisões, e, portanto, da 
própria elaboração das políticas públicas, por meio da criação de instrumentos adequados para essa participação.

O discurso do sujeito coletivo, no que se refere às ameaças e oportunidades, vem complementar esse entendimento, ao apontar como principais ameaças à atual gestão ambiental do pólo industrial de Cubatão a possibilidade de relaxamento no controle e fiscalização ambiental, inclusive de áreas protegidas, privilegiando-se o crescimento econômico de curto prazo, em detrimento do planejamento de longo prazo, tanto por parte do setor governamental quanto por parte do setor empresarial.

A falta de investimentos em educação ambiental e no fornecimento de infraestrutura adequada e capacitação dos órgãos ambientais representa, conforme o discurso produzido, outra importante ameaça à gestão ambiental adequada do pólo industrial, assim como a possibilidade de desmonte da legislação ambiental, como decorrência de uma visão equivocada da questão ambiental como entrave ao desenvolvimento do pólo e do país, tanto pelo setor empresarial, quanto governamental e sociedade civil, aliada a um certo comodismo por parte desta, que poderia decorrer da falta de informações suficientes e adequadas, ficando a população sujeita a receber informações distorcidas e oportunistas, aspectos também mencionados dentre as ameaças.

Outra ameaça à gestão do pólo industrial de Cubatão apontada pelo discurso é a falta de planejamento do uso e ocupação do solo, favorecendo o crescimento urbano desordenado, com ocupações em áreas ambientalmente protegidas, revelando a necessidade de ampliação da gestão ambiental para aspectos que vão além do controle específico da poluição.

A coerência do discurso do sujeito coletivo é verificada no resultado obtido no que se refere às oportunidades. Foi constatado que o discurso enfatiza o desenvolvimento do município em consonância com as exigências do desenvolvimento sustentável como importante oportunidade da gestão atual, inclusive para a melhoria do desempenho econômico das empresas, atendendo, ainda, aos anseios do público.

Outra oportunidade mencionada diz respeito ao surgimento de novos ramos de negócios decorrentes de uma gestão ambiental adequada, seja pela necessidade de adoção de medidas de controle e de recuperação ambiental, seja pela valorização de 
características ambientais do município (turismo ecológico), contribuindo para a geração de empregos. São apontadas, também, como oportunidades à atual gestão, a realização de investimentos na capacitação técnica dos órgãos públicos, do setor empresarial e da sociedade civil, investimentos em educação ambiental, inclusive para viabilizar a participação desta última nos processos de tomada de decisões e na disseminação do conhecimento, bem como a ampliação e intensificação do debate sobre as questões ambientais entre todos os interessados e o aproveitamento da Agenda 21 local na implementação do desenvolvimento sustentável do município, com a definição de indicadores para avaliar essa implementação. 


\section{CONSIDERAÇÕES GERAIS E RECOMENDAÇÕES}

Os resultados deste trabalho confirmam o papel central das políticas públicas ambientais para a mudança de comportamento da sociedade em geral e das empresas, em particular, no trato das questões ambientais, sendo vital para tanto a existência de uma base legal consistente para sua implementação.

A experiência de Cubatão também revelou a importância de instituições fortes na tutela do meio ambiente e demais interesses difusos e coletivos, bem como que essas instituições devem atuar não apenas próximas à comunidade, mas junto com esta, visto que é a participação e o apoio da sociedade civil na criação e implementação das políticas públicas que dá legitimidade e fortalece as ações das instituições incumbidas da proteção do meio ambiente. As pressões da comunidade, dos consumidores, dos segmentos organizados da sociedade civil, são determinantes dos rumos da política pública ambiental e de iniciativas empresariais de autoregulamentação em prol do desenvolvimento sustentável.

A mídia, como formadora de opinião e instrumento de pressão, também exerce papel fundamental no processo de implementação do desenvolvimento sustentável, seja ao atrair a atenção para os problemas ambientais e sociais, conscientizando a população, seja ao cobrar soluções para esses problemas, apoiando as ações daquela.

A atuação da comunidade científica é outro ponto que merece menção, a qual exerceu importante papel na melhoria do contexto de degradação ambiental de Cubatão, reforçando o papel da universidade como produtora de conhecimento que possa trazer benefícios sociais.

Outro aspecto relevante diz respeito à atuação mais integrada entre o setor governamental, empresarial e sociedade civil como facilitador da solução dos conflitos, sendo fundamental a existência de instrumentos adequados que possibilitem essa atuação, como é o caso do Termo de Compromisso de Ajustamento de Conduta.

A par dessas considerações, diante dos resultados da pesquisa, os quais revelam que, a despeito dos avanços obtidos em Cubatão no controle da poluição do meio ambiente, ainda não foi alcançada uma qualidade de vida compatível com o 
desenvolvimento sustentável, são feitas abaixo algumas recomendações, com o intuito de contribuir para o aperfeiçoamento das políticas públicas ambientais necessárias para a melhoria da situação do município:

1. Que sejam adotadas pela CETESB ações específicas para a melhoria da qualidade das águas dos rios do município, tendo em vista não somente a captação para o abastecimento público, mas a qualidade para a vida aquática;

2. Que seja exigido pela CETESB o efetivo cumprimento do art. 46, da Resolução CONAMA n $357 / 05$, pelas empresas do pólo industrial e Cubatão, a fim de que se conheça a carga poluidora de cada uma delas;

3. Que sejam adotadas pela CETESB as medidas necessárias para a realização de inventário anual dos resíduos sólidos industriais gerados pelas empresas do pólo industrial de Cubatão, com identificação do tipo de resíduo e destinação;

4. Que seja implementado em Cubatão, pela CETESB, o monitoramento contínuo das emissões atmosféricas, conforme previsto na Resolução CONAMA no 382/06, a fim de permitir a avaliação das reais emissões das indústrias;

5. Que a CETESB, considerando a falta de informações adequadas para avaliar a gestão ambiental do município, aproveitando a oportunidade de reestruturação atual, implemente setor capacitado para a coleta e sistematização de informações que propiciem base mais adequada para o processo de tomada de decisões, bem como para que não se perca o histórico do importante trabalho já desenvolvido pelo órgão ambiental, com divulgação dessas informações à sociedade civil;

6. Que no processo contínuo de melhoria da qualidade do ar, seja considerada a oportunidade de estabelecimento de padrões de emissão mais restritivos para o município de Cubatão, que leve em conta características específicas deste, o não atendimento aos padrões de qualidade do ar em tempo integral, bem como a oportunidade da recente revisão feita pela Organização Mundial de Saúde-OMS dos padrões de qualidade do ar, que foram reduzidos para três dos principais poluentes atmosféricos: partículas inaláveis, ozônio e dióxido de enxofre;

7. Que a CETESB retome a atuação mais próxima da comunidade, que foi interrompida em momento que não foi possível identificar nesta pesquisa;

8. Que, sem prejuízo do aperfeiçoamento das informações produzidas pelo órgão ambiental estadual, o município de Cubatão construa sistema de informações sobre 
todos os aspectos ambientais, sociais, econômicos e institucionais importantes para a avaliação do caminho na direção do desenvolvimento sustentável, com ampla participação da sociedade civil nesse processo;

9. Que o município de Cubatão construa indicadores para acompanhamento da implementação da Agenda 21 local;

10. Que sejam implementados pelo município de Cubatão programas de educação ambiental e de capacitação da população na área de meio ambiente e desenvolvimento sustentável, a fim de garantir maior participação da sociedade civil na criação e implementação de políticas públicas;

11. Que sejam adotadas pelo município de Cubatão medidas efetivas para a melhoria da qualidade de vida da população, em especial visando à solução dos problemas habitacionais e de falta saneamento básico;

12. Que o município de Cubatão, caracterizado como região de alta vulnerabilidade ecológica e abrigando importante remanescente de um dos biomas mais ameaçados do mundo, a Mata Atlântica, adote medidas efetivas para a proteção do meio ambiente, que é um dos deveres do Poder Público, por meio de legislação específica, bem como maior dotação orçamentária para a gestão ambiental municipal;

13. Que o governo do Estado de São Paulo propicie à Fundação SEADE (Fundação Sistema Estadual de Análise de Dados) - sem questionar o importante trabalho que já vem sendo realizado por essa instituição - infra-estrutura adequada para a geração de maiores informações, que permitam o pleno conhecimento e compreensão da realidade paulista, inclusive de cada um dos municípios, visando orientar a elaboração de políticas públicas eficazes para a promoção do desenvolvimento sustentável no Estado.

14. Como contribuição para futuras pesquisas, merecem ser objeto de estudos específicos: a) o desempenho ambiental do pólo industrial de Cubatão, em termos de ecoeficiência econômica; b) os indicadores de desenvolvimento sustentável necessários para o município;

c) a avaliação de eventuais efeitos positivos dos programas de responsabilidade sócio-ambiental das indústrias de Cubatão sobre a qualidade de vida da população do município. 


\section{REFERÊNCIAS BIBLIOGRÁFICAS}

1. ABIQUIM-Associação Brasileira da Indústria Química. Atuação Responsável. Disponível em: <http://www.abiquim.org.br/conteudo.asp?princ=atu\&pag=prog> Acesso em 27 nov. 2006.

2. AGUIAR, A. O. Sistemas de gestão ambiental na indústria química: desempenho, avaliação e benefícios. 2004. 195 p. Tese (Doutorado em Saúde Pública) - Faculdade de Saúde Pública, Universidade de São Paulo, São Paulo.

3. AlmeIDA, L. T. Política Ambiental: uma análise econômica. São Paulo, Papirus/FEUNESP, 1998.

4. BANCO MUNDIAL. Diretoria Sub-Regional - Brasil. Diretoria Setorial Desenvolvimento Ambiental e Social Sustentáveis. Região da América Latina e Caribe. Brasil: Gestão dos Problemas da Poluição. A Agenda Ambiental Marrom. Volume I: Relatório de Política. Fevereiro de 1998.

5. BARBIERI, J. C. Desenvolvimento e Meio Ambiente: As estratégias de mudanças da Agenda 21. Petrópolis-RJ, Vozes, 1997.

6. BARBIERI, J. C. Gestão Ambiental Empresarial: conceitos, modelo e instrumentos. São Paulo, Saraiva, 2006.

7. BECK, E. C. The Love Canal Tragedy. EPA Journal. New York, jan 1979. Disponível em: http://www.epa.gov/history/topics/lovecana//01.htm Acesso em 04 mai. 2007.

8. BELLEN, H. M. Indicadores de Sustentabilidade: uma análise comparativa. Rio de Janeiro, FGV, 2005.

9. BOSSEL, H. Indicators for sustainable development: theory, method, applications. A report to the Balaton Group. Canadá: IISD, 1999. Disponível em: <http://www.iisd.org/pdf/balatonreport.pdf> Acesso em 07 mar. 2005.

10. BRAGA, T. M. et. al. Índices de Sustentabilidade municipal: o desafio de mensurar. Nova Economia, Belo Horizonte, v. 14, n. 3, p. 11-33, set-dez 2004.

11. BRANCO, S. M. O fenômeno Cubatão na visão do ecólogo. São Paulo, CETESB/ASCETESB, 1984.

12. BRASIL. Constituição (1988). Constituição da República Federativa do Brasil. Brasília, DF: Senado, 1988.

13. BRASIL. Decreto Federal no 87.000, de 09 de março de 1982. Cria Comissão Interministerial com vistas à recuperação, controle e prevenção da qualidade ambiental em Cubatão e dá outras providências. Diário Oficial da União. Brasília, DF, 10 mar. 1982. 
14. BRASIL. Lei ${ }^{\circ} 5.966$, de 11 de dezembro de 1973. Institui o Sistema Nacional de Metrologia, Normalização e Qualidade Industrial. Diário Oficial da União. Brasília, DF, 12 dez. 1973, Seção I.

15. BRASIL. Lei no 6.938, de 31 de agosto de 1981. Dispõe sobre a Política Nacional do Meio Ambiente, seus fins e mecanismo de formulação e aplicação, e dá outras providências. Diário Oficial da União. Brasília, DF, 02 set. 1981.

16. CALDEIRA, T. P. R. A política dos outros: O cotidiano dos moradores da periferia e o que pensam do poder e dos poderosos. São Paulo, Brasiliense, 1984.

17. CETESB-Companhia Estadual de Tecnologia de Saneamento Ambiental; DAEEDepartamento de Águas e Energia Elétrica do Estado de São Paulo. Resíduos Sólidos Industriais na Bacia do Rio Cubatão: relatório técnico. São Paulo, CETESB, 1978, 2v, 299p.

18. CETESB-Companhia Estadual de Tecnologia de Saneamento Ambiental. Plano de ação para solução da problemática ambiental em Cubatão (Sub-comissão de controle-Vilalpa 17/06/1983): relatório técnico. São Paulo, CETESB, 1983a, $37 \mathrm{p}$.

19. CETESB-Companhia Estadual de Tecnologia de Saneamento Ambiental. Plano de ação para Controle da Poluição Ambiental em Cubatão: relatório técnico. São Paulo, CETESB, 1983b, 25p.

20. CETESB-Companhia Estadual de Tecnologia de Saneamento Ambiental. A degradação da vegetação da Serra do Mar em Cubatão: relatório preliminar. São Paulo, CETESB, 1984, 56p.

21. CETESB-Companhia Estadual de Tecnologia de Saneamento Ambiental. Baixada Santista: Carta do Meio Ambiente e de sua Dinâmica. São Paulo: CETESB, 1985a, 33 p.

22. CETESB-Companhia Estadual de Tecnologia de Saneamento Ambiental. Desenvolvimento Ambiental Regional no Estado de São Paulo. Controle de poluição ambiental em Cubatão: relatório técnico. São Paulo, CETESB, 1985b, 108p.

23. CETESB-Companhia Estadual de Tecnologia de Saneamento Ambiental. Desenvolvimento Ambiental Regional no Estado de São Paulo. Controle da poluição ambiental em Cubatão: Resultados-Julho/83 a Julho/86. Relatório técnico. São Paulo, CETESB, 1986, 28p.

24. CETESB-Companhia Estadual de Tecnologia de Saneamento Ambiental. Desenvolvimento Ambiental Regional no Estado de São Paulo. Ação da 
CETESB em Cubatão: situação em Julho de 1989. Relatório técnico. São Paulo, CETESB, 1989, 13p.

25. CETESB-Companhia Estadual de Tecnologia de Saneamento Ambiental. Desenvolvimento Ambiental Regional no Estado de São Paulo. Ação da CETESB em Cubatão: situação em Janeiro de 1990. Relatório técnico. São Paulo, CETESB, 1990, 13p.

26. CETESB-Companhia Estadual de Tecnologia de Saneamento Ambiental. Desenvolvimento Ambiental Regional no Estado de São Paulo. Ação da CETESB em Cubatão: situação em Junho de 1994. Relatório técnico. São Paulo, CETESB, 1994, 25p.

27. COMISSÃO INTERMINISTERIAL DE CUBATÃO. Subcomissão de Poluição do Ar, Água e Resíduos Sólidos. Qualidade Ambiental em Cubatão: subsídio para uma política de ação. Relatório apresentado à Comissão Interministerial criada pelo Decreto Federal 87000/82. São Paulo, 1982, 102p.

28. CMMAD- COMISSÃO MUNDIAL SOBRE MEIO AMBIENTE E DESENVOlVIMENTO. Nosso Futuro Comum. Rio de Janeiro, Ed. FGV, 1991.

29. CONSELHO NACIONAL DE METROLOGIA, NORMALIZAÇÃO E QUALIDADE INDUSTRIAL. Resolução $\mathrm{n}^{\circ}$ 07, de 24 de agosto de 1982. Determina que o sistema de normalização do SINMETRO terá um foro de normalização único. Diário Oficial da União. Brasília, DF, 27 ago. 1982, Seção 1, pág. 11728.

30. CONSELHO NACIONAL DO MEIO AMBIENTE. Resolução n ${ }^{\circ}$ 237, de 19 de dezembro de 1997. Dispõe sobre a revisão de procedimentos e critérios utilizados pelo Sistema de Licenciamento Ambiental instituído pela Política Nacional do Meio Ambiente. Diário Oficial da União. Brasília, DF, 22 dez. 1997.

31. CORREIA, A. Responsabilidade civil pelos resíduos do produto pósconsumo. 2005. 160 p. Dissertação (Mestrado) - Faculdade de Direito, Universidade de São Paulo, São Paulo.

32. COUTINHO, S. M. V. Análise de um processo de criação de indicadores de desenvolvimento sustentável no município de Ribeirão Pires-SP. 2006. 173 p. Dissertação (Mestrado em Saúde Ambiental) - Faculdade de Saúde Pública, Universidade de São Paulo, São Paulo.

33. CUBATÃO. Prefeitura Municipal. 4º Boletim Informativo. Cubatão, 1976.

34. CUBATÃO. Prefeitura Municipal. Lei Complementar $n^{\circ} 2.513$, de 10 de setembro de 1998. Institui normas sobre o parcelamento, uso e ocupação do solo 
do município de Cubatão, e dá outras providências. Câmara Municipal de Cubatão. Cubatão, 15 set. 1998.

35. DALLARI, D. A. O Futuro do Estado. São Paulo, Saraiva, 2001.

36. D'LSEP, C. F. M. Direito Ambiental Econômico e a ISO 14000: análise jurídica do modelo de gestão ambiental e certificação ISO 14001. São Paulo, RT, 2004.

37. EPA- United States Environmental Protection Agency. Love Canal Record of Decision Signed. Nem York, oct 1987. Disponível em: <http://www.epa.gov/history/topics/lovecanal/04.htm> Acesso em 04 mai. 2007.

38. EPA- United States Environmental Protection Agency. EPA Removes Love Canal from Superfund List. Nem York, sep 2004. Disponível em: <http://www.epa.gov/superfund/news/lovecanal.htm> Acesso em 04 mai. 2007.

39. FEEMA-Fundação Estadual de Engenharia do Meio Ambiente. Inventário de fontes emissoras de poluentes atmosféricos da Região Metropolitana do Rio de Janeiro: relatório técnico. Rio de Janeiro, FEEMA, 2004. Disponível em: <http://www.feema.rj.gov.br/admin_fotos/INVENTARIO_\%20Relatorio.pdi> Acesso em 04 jul. 2007.

40. FERREIRA, L. C. Os Fantasmas do Vale: qualidade ambiental e cidadania. Campinas, SP, UNICAMP, 1993.

41. FONSECA JR, Z. M.; CANTARINO, A. A. A. O seguro ambiental na legislação nacional e o sistema de gestão ambiental. Rio de Janeiro, 2004. Disponível em: <http://www.ebape.fgv.br/radma/doc/EMA/EMA-036-pdt> Acesso em 04 jul. 2007.

42. FUNDAÇÃO SEADE. Índice Paulista de Responsabilidade Social. São Paulo, 2004. Disponível em <http://www.seade.gov.br/produtos/iprs/pdt/oiprs/pdt> Acesso em: 29 nov. 2005.

43. FUNDAÇÃO SEADE. Índice Paulista de Vulnerabilidade Social. São Paulo, 2007a. Disponível em <http://www.seade.gov.br/produtos/ipvs/pdt/oipvs/pdt> Acesso em: 05 mar. 2007.

44. FUNDAÇÃO SEADE. Informações dos Municípios Paulistas. São Paulo, 2007b. Disponível em <http://www.seade.gov.br/produtos/implindex.php> Acesso em: 16 abr. 2007.

45. FUNDAÇÃO SEADE. Perfil Municipal. São Paulo, 2007c. Disponível em <http://www.seade.gov.br/produtos/perfil/perfil.php> Acesso em: 16 abr. 2007.

46. GIL, A. C. Como elaborar projetos de pesquisa. São Paulo, Atlas, 2002. 
47. GIUSSANI, V. The UK Clean Air Act 1956: an empirical investigation. London, $\quad$ England, $1994 . \quad$ Disponível em <http://www.uea.ac.uk/env/cserge/pub/wp/gec/gec_1994_20.pdf> Acesso em 25 mai. 2007.

48. GOLDENSTEIN, L. et alii. Cubatão e sua área industrial. In: A Baixada Santista-Aspectos Geográficos. São Paulo: Edusp, 1965, v. 4, p. 11-65.

49. GUILHERME, M. L. Urbanização, saúde e meio ambiente: o caso da implantação do pólo industrial de Cubatão e os seus efeitos urbanos e regionais nos setores de saúde e poluição ambiental. In: TARTAGLIA, J. C.; OLIVEIRA, O. L. (Orgs.). Modernização e Desenvolvimento no Interior de São Paulo. São Paulo, UNESP, 1988.

50. GUTBERLET, J. Cubatão: Desenvolvimento, Exclusão Social e Degradação Ambiental. São Paulo, Edusp, Fapesp, 1996.

51. HARDI, P.; ZDAN, T. Assessing sustainable development: principles in practice. Winnipeg: IISD, 1997. Disponível em: <http://www.iisd.org/pdf/bellagio/pdi> Acesso em 10 jun. 2005.

52. HUNT, C. B.; AUSTER, E. R. Proactive environmental management: avoiding the toxic trap. Sloan Management Review. Columbia University, winter, 1990, p. 7-18.

53. IBGE-Instituto Brasileiro de Geografia e Estatística. Indicadores de Desenvolvimento Sustentável: Brasil, 2002. Rio de Janeiro, 2002.

54. IBGE-Instituto Brasileiro de Geografia e Estatística. Indicadores de Desenvolvimento Sustentável: Brasil, 2004. Rio de Janeiro, 2004.

55. IMURA, H. Air Pollution Control Policies and the Changing Attitudes of the Public and Industry: Paradigmatic Changes in Environmental Management in Japan. In: Environmental Pollution Control: The Japanese Experience. Papers presented at the UNU International Symposium on Eco-Restructuring. TokyoJapan, The United Nations University, 5-7 July 1993, p. 55-85.

56. IPDSC-Instituto de Pesquisa do Discurso do Sujeito Coletivo Ltda. DSC/Qualiquantisoft. São Paulo, 2007. Disponível em http://www.ipdsc.com.br/scp/showtexto.php?pag=2 Acesso em 09 mai 2007.

57. KRONKA, F. J. N. et. al. Inventário Florestal da Vegetação Natural do Estado de São Paulo. São Paulo, SMA/Instituto Florestal, Imprensa Oficial, 2005.

58. LEFÉVRE, F.; LEFÉVRE, A. M. C. O discurso do sujeito coletivo: Um novo enfoque em pesquisa qualitativa (desdobramentos). Caxias do Sul, RS, Educs, 2005. 
59. LEMOS, M. C. M. The Politics of Pollution Control in Cubatão: State Actors and Social Movements in the Environmental Policy Making Process. 1995. 330p. Tese (Doutorado em Filosofia em Ciência Política) - Massachusetts Institute of Technology, Massachusetts, US.

60. MACHADO, C. J. S. Mudanças Conceituais na Administração Pública do Meio Ambiente. Ciência e Cultura. Revista da Sociedade Brasileira para o Progresso da Ciência. Rio de Janeiro, ano 55, n. 4, p. 24-26, out/dez 2003.

61. MAPAC-The Manchester Area Pollution Advisory Council. Air Quality Action Plan. Manchester, England, 2005. Disponível em <http://www.mapac.org.uk/mapac_frame_airquality.htm> Acesso em 23 mai. 2007.

62. MARTINS, S. R. et. al. Instrumentos tecnológicos e jurídicos para a construção da sociedade sustentável. In: VIANA, G.; SILVA, M.; DINIZ, N. (Orgs). O desafio da sustentabilidade. Um debate socioambiental no Brasil. São Paulo, Fundação Perseu Abramo, 2001, p. 157-182.

63. MATSUI, S. Industrial Pollution Control in Japan: A Historical Perspective. In: Environmental Pollution Control: The Japanese Experience. Papers presented at the UNU International Symposium on Eco-Restructuring. Tokyo-Japan, The United Nations University, 5-7 July 1993, p. 1-54.

64. MEADOWS, D. Indicators and Information Systems for Sustainable Development. The Sustainability Institute, 1998. Disponível em: <http://www.nssd.net/pdf/Donella.pdf> Acesso em: 2005

65. MEDEIROS, M. H. G. et. al. Oxygen toxicity and hemoglobinemia in subjects from a highly polluted town. Archives of Environmental Health. v. 38, n. 1, p. 11-16, jan-fev 1983.

66. MERICO, L. F. K. Políticas públicas para a sustentabilidade. In: VIANA, G.; SILVA, M.; DINIZ, N. (Orgs). O desafio da sustentabilidade. Um debate socioambiental no Brasil. São Paulo, Fundação Perseu Abramo, 2001, p. 251262.

67. MILARÉ, E. Direito do Ambiente: doutrina, prática, jurisprudência, glossário. São Paulo, RT, 2000.

68. MINAYO, M. C. S. O desafio do conhecimento: pesquisa qualitativa em saúde. São Paulo-Rio de Janeiro, Hucitec-Abrasco, 1999.

69. MONTELEONE NETO, R. As anomalias congênitas e as perdas gestacionais intermediárias e tardias no município de Cubatão. 1986. 75 p. Dissertação (Mestrado) - Universidade de São Paulo, Ribeirão Preto, São Paulo. 
70. MOREIRA, M. S. Estratégia e Implantação do Sistema de Gestão Ambiental Modelo ISO 14000. Nova Lima, INDG, 2006.

71. MOTTA, R. S.; MENDES, F. E. Instrumentos econômicos na gestão ambiental: aspectos teóricos e de implementação. In: ROMEIRO, A. R.; REYDON, B. P.; LEONARDI, M. L. A. (Orgs). Economia do Meio Ambiente: teoria, políticas e a gestão de espaços regionais. Campinas, UNICAMP, Instituto de Economia, 2001, p. 127-152.

72. MOURA, L. A. A. Qualidade e gestão ambiental: sugestões para implantação das Normas ISO 14000 nas empresas. São Paulo, Ed. Oliveira Mendes, 1998.

73. NAOUM, P. C. et. al. Toxic Methaemoglobinaemia and sulphaemoglobinaemia in a population from Cubatão (SP, Brazil): effect of industrial pollution? Ciência e Cultura, São Paulo, v. 34, n. 4, p. 529-531, 1982.

74. NAOUM, P. C. et. al. Alterações hematológicas induzidas por poluição industrial em moradores e industriários de Cubatão, SP (Brasil). Revista de Saúde Pública, São Paulo, n. 18, p. 271-277, 1984.

75. NEPP-Núcleo de Estudos de Políticas Públicas. Documento de Referência DNA Brasil - versão 2006. Unicamp-Campinas, 2006. Disponível em: <http://www.nepp.unicamp.br/dnabrasil/referenciadnabrasil2006.pdf> Acesso em 07 mar. 2007.

76. NEPP-Núcleo de Estudos de Políticas Públicas. Índice DNA Brasil - versão 2006. Unicamp-Campinas, 2006. Disponível em: <http://www.nepp.unicamp.br/dnabrasil/transparenciadnabrasil2006.pdf> Acesso em 07 mar. 2007.

77. NOBRE, M. Desenvolvimento sustentável: origens e significado atual. In: NOBRE, M.; AMAZONAS, M. C. (Orgs.). Desenvolvimento Sustentável: A Institucionalização de um Conceito. Brasília, IBAMA, 2002, p. 21-106.

78. PERALTA, I. G. O impacto da industrialização sobre o desenvolvimento urbano de Cubatão. 1979. 260 p. Tese (Doutorado em História Econômica) Faculdade de Filosofia, Letras e Ciências Humanas, Universidade de São Paulo, São Paulo.

79. PETILLO, V. L. S. Gestão Ambiental na Indústria Química Brasileira: uma análise do período de 1990 a 1995. 1997, 106p. Dissertação (Mestrado). Universidade Mackenzie, São Paulo.

80. PHILIPPI JR, A.; BRUNA, G. C. Política e Gestão Ambiental. In: PHILIPPI JR, A.; ROMÉRO, M. A.; BRUNA, G. C. (Editores). Curso de Gestão Ambiental. Barueri, SP, Manole, 2004, p. 657-711. 
81. PHILIPPI JR, A. et. al. Gestão Ambiental Municipal: Subsídios para Estruturação de Sistema Municipal de Meio Ambiente. Série: Construindo os Recursos do Amanhã, v. 4. Salvador, 2004.

82. PHILIPPI JR, A. et. al. Indicadores de Desenvolvimento Sustentável. In: PHILIPPI JR, A. (Editor). Saneamento, saúde e ambiente: fundamentos para um desenvolvimento sustentável. Barueri, SP, Manole, 2005, p. 761-808.

83. PORTER, M. E.; LINDE, C. Green and competitive: ending the stalemate. Harvard Business Review. Harvard College, p. 120-134, sep-oct 1995.

84. PÜTZ, M. Monitoring Industrial Emissions: a successful instrument for environmental enforcement. Dusseldorf, Germany, 2006. Disponível em <http://www.inece.org//rdvol1/pdt/putz.pdf> Acesso em 18 mai. 2007.

85. REZENDE, S. C.; HELLER, L. O Saneamento no Brasil: políticas e interfaces. Belo Horizonte, UFMG, 2002.

86. RIBEIRO, J. C. J. Indicadores Ambientais: avaliando a política de meio ambiente no Estado de Minas Gerais. Belo Horizonte, Semad, c2006.

87. SACHS, I. Caminhos para o desenvolvimento sustentável. Rio de Janeiro, Garamond, 2000.

88. SAINT ANDREWS UNIVERSITY. Pollution Control in UK. England. Disponível em <http://www.st-andrews.ac.uk/ dib2/atmost/control.html> Acesso em 25 mai. 2007.

89. SÁNCHEZ, L. E. Gerenciamento ambiental e a indústria de mineração. Revista de Administração, São Paulo, v. 29, n. 1, p. 67-75, jan/mar 1994.

90. SÁNCHEZ, L. E. Industry Response to the Challenge of Sustainability: The Case of the Canadian Nonferrous Mining Sector. Environmental Management, New York, v. 22, n. 04, p. 521-531, 1998.

91. SÁNCHEZ, L. E. Economic Development, Environmental Degredation, and Social Exclusion in an Urban-Industrial Region: Unsustainability in Cubatão and the Santista Lowlands, Southeastern Brazil. In: Session workbook: cohort 8 associates 1999-2001. Diversity and Societies in Transition: Challenges for Sustainability in a Globalized World, São Paulo, LEAD International/ABDL, p. 330-337, 2000.

92. SÃO PAUlO, Governo do Estado. A Batalha do Meio Ambiente no Governo Montoro. São Paulo, PW, 1987.

93. SÃO PAULO (Estado). Decreto no 47.397, de 04 de dezembro de 2002. Dá nova redação ao Título $\mathrm{V}$ e ao Anexo 5 e acrescenta os Anexos 9 e 10, ao Regulamento da Lei $\mathrm{n}^{\circ}$ 997, de 31 de maio de 1976, aprovado pelo Decreto $\mathrm{n}^{\circ}$ 
8.468, de 8 de setembro de 1976, que dispõe sobre a prevenção e o controle da poluição do meio ambiente. Diário Oficial do Estado de São Paulo. São Paulo, 05 dez. 2002, p. 3. Retificado de acordo com o D. O. de 07 dez. 2002.

94. SILVA, J. A. Direito Ambiental Constitucional. São Paulo, Malheiros, 2000.

95. SILVA, P. C. R. Amostragem: Introdução à Estatística Econômica. FACEV. Disponível em: http://www.geocities.com/Paris/Rue/5045/2A3.HTM Acesso em 27 set 2005.

96. SOUZA, M. P. Instrumentos de Gestão Ambiental: fundamentos e prática. São Carlos, Ed. Riani Costa, 2000.

97. SPÍNOLA, A. W. P. Metodologia do Trabalho Científico em Ciências Ambientais. In: PHILIPPI JR, A.; ALVES, A. C. (Editores). Curso Interdisciplinar de Direito Ambiental. Barueri, SP, Manole, 2005, p. 916-942.

98. TAYRA, F.; RIBEIRO, H. Modelos de Indicadores de Sustentabilidade: síntese e avaliação crítica das principais experiências. Saúde e Sociedade, São Paulo, v. 15, n. 1, p. 84-95, jan-abr 2006.

99. UNITED NATIONS. Report of the United Nations Conference on Environment and Development. Rio Declaration on Environment and Development. New York, 1992. Disponível em: <http://www.un.org/documents/ga/conf151/aconf15126-1annex1.htm> Acesso em 10 jun. 2005.

100. UNITED NATIONS. Department of Economic and Social Affairs. Division for Sustainable Development. Agenda 21. New York, 1992. Disponível em: <http://www.un.org/esa/sustdev/documents/agenda21/index.htm> Acesso em 10 jun. 2005.

101. UNITED NATIONS. Department of Economic and Social Affairs. Division for Sustainable Development. Indicators of Sustainable Development: framework and methodologies. New York, 1996. Disponível em: <http://www.un.org/esa/sustdev/natlinfo/indicators/indisd/english/english.htm> Acesso em 26 jun. 2005.

102. UNITED NATIONS. Earth summit + 5: Special Session of the general Assembly to review and appraise the implementation of Agenda 21. 19 ${ }^{\text {a }}$ Special Session, 1997. Disponível em: <http://www.un.org/esa/earthsummit/ga97info.htm> Acesso em 15 set. 2006.

103. UNITED NATIONS. United Nations Millennium Declaration. 55 Special Session, 2000. Disponível em: <http://www.un.org/millennium/declaration/ares552e.pdi> Acesso em 15 set. 2006.

104. UNITED NATIONS. Indicators of Sustainable Development: framework and methodologies. New York, 2001a. Disponível em: <http://www.un.org/esa/sustdev/csd/csd9_indi_bp3.pdi> Acesso em 26 jun. 2005. 
105. UNITED NATIONS. Indicators of Sustainable Development: guidelines and methodologies. New York, 2001b. Disponível em: <http://www.un.org/esa/sustdev/publications/indisd-mg2001.pdf> Acesso em 26 jun. 2005.

106. UNITED NATIONS. Report of the world summit on sustainable development. Johannesburg, South Africa, 26 August - 4 september 2002. Nem York, 2002.

Disponível em: <http://daccessdds.un.org/doc/UNDO/GEN/N02/636/93/PDF/N0263693pdf?OpenElement> Acesso em 15 set. 2006.

107. VEIGA, J. E. Meio Ambiente e Desenvolvimento. São Paulo, Senac-SP, 2006.

108. WACKERNAGEL, M. What we use and what we have: ecological footprint and ecological capacity. USA, 2002. Disponível em: <http://www.redefining progress.org> Acesso em 20 nov. 2005.

109. WELFORD, R. Business Ethics and Corporate Environmental Performance. In: Environmental strategy and sustainable development: the corporate challenge for the $\mathbf{2 1}^{\text {st }}$ century, cap. 5. Routledge, London, 1995, p. 28-49. 


\section{ANEXO 1 \\ QUESTIONÁRIO}




\section{QUESTIONÁRIO:}

1. Identifique $\underline{\mathbf{0 5}(\text { cinco) }}$ dentre os fatores abaixo indicados que, na sua visão, foram os principais determinantes da evolução do controle da poluição em Cubatão, desde o início da implantação do Programa de Controle da Poluição do município, em 1983, até os dias atuais, numerando-os em ordem de importância de 01 a 05, acrescentando até no máximo dois outros fatores.

( )Exigências de mercado local

( )Pressão da mídia

( )Promulgação da Constituição Federal de 1988

( )Atuação do Poder Executivo do Município de Cubatão

( )Autuações da CETESB (multas administrativas)

( ) Pressão da comunidade científica

( )Ações Civis Públicas movidas pelo Ministério Público

( )Atuação de ONGs

( ) Edição da Lei dos Crimes Ambientais (Lei 9.605/98)

( )Conscientização ambiental dos dirigentes das indústrias

( )Orientação e apoio técnico da CETESB

( )Termos de ajustamento de conduta formulados com o Ministério Público

( )Avanço do conhecimento científico/tecnológico

( ) Exigências de mercado internacional

( )Atuação do Poder Legislativo do Município de Cubatão

( ) Pressão da comunidade do Município de Cubatão

( ) Edição da Lei de Ação Civil Pública (Lei 7.347/85)

( )Atuação do CONSEMA

( )Decisões do Poder Judiciário

( )Exigências da Matriz Internacional

( )

( )

Justifique a resposta: 
2. Visando subsidiar a compreensão do atual sistema de gestão ambiental do pólo industrial de Cubatão, identificar, no que se relaciona ao setor governamental, empresarial e sociedade civil, no seu entendimento:

-Pontos fracos da gestão atual:

-Pontos fortes da gestão atual:

-Ameaças:

-Oportunidades: 


\section{CONSENTIMENTO LIVRE E ESCLARECIDO}

$\mathrm{Eu}$,

_aceito

participar da pesquisa para a qual fui convidado(a), contribuindo com uma entrevista e/ou participando de grupo de discussão, parte da dissertação de Mestrado na Faculdade de Saúde Pública da Universidade de São Paulo, de responsabilidade da pesquisadora Liliane Garcia Ferreira, que irá analisar A Gestão Ambiental do Pólo Industrial de Cubatão a partir do Programa de Controle de Poluição iniciado em 1983: atores, instrumentos e indicadores.

Sei que minha participação é livre, não é obrigatória, podendo ser interrompida por minha decisão a qualquer momento, sem qualquer prejuízo.

Assinatura: Data: --/---/

Essa pesquisa visa contribuir para o aperfeiçoamento da Gestão Ambiental do pólo industrial de Cubatão, avaliar o sistema de informações existente e propor novos indicadores que permitam a correta avaliação dessa gestão, se o caso, bem como identificar eventuais instrumentos que possam dar suporte ao estabelecimento de políticas públicas de implementação do desenvolvimento sustentável no país. Desse modo, como pesquisadora, comprometo-me tanto a devolver os resultados obtidos ao final da pesquisa, quanto a garantir o anonimato associado ao conteúdo da entrevista e dos grupos de discussões.

Para qualquer informação adicional terei disponível para contatos o telefone: $11-8105-9262$

Pesquisadora Liliane Garcia Ferreira 
Orientador Prof. Dr. Arlindo Philippi Júnior

Tel: $0 X X-11-3066-7712$ 


\section{ANEXO 2 \\ QUADROS SINÓPTICOS DOS INDICADORES DE DESENVOLVIMENTO SUSTENTÁVEL UTILIZADOS NA \\ PESQUISA}




\section{INDICADOR:}

Quantidade de emissões dos poluentes atmosféricos material particulado (MP), dióxido de enxofre $\left(\mathrm{SO}_{2}\right)$, óxidos de nitrogênio $\left(\mathrm{NO}_{\mathrm{x}}\right)$ e hidrocarbonetos $(\mathrm{HC})$

PARÂMETROS:

Estimativas de emissões dos poluentes material particulado (MP), dióxido de enxofre $\left(\mathrm{SO}_{2}\right)$, óxidos de nitrogênio $\left(\mathrm{NO}_{\mathrm{x}}\right)$ e hidrocarbonetos $(\mathrm{HC})$, em tonelada/ano

METAS OU VALORES DE REFERÊNCIA:

Redução das emissões

PROCEDIMENTO DE COLETA:

Consultar o site da CETESB (www.cetesb.sp.gov.br)

ASPECTOS QUALITATIVOS PARA INTERPRETAÇÃO:

Não se aplica

\section{EVOLUÇÃO:}

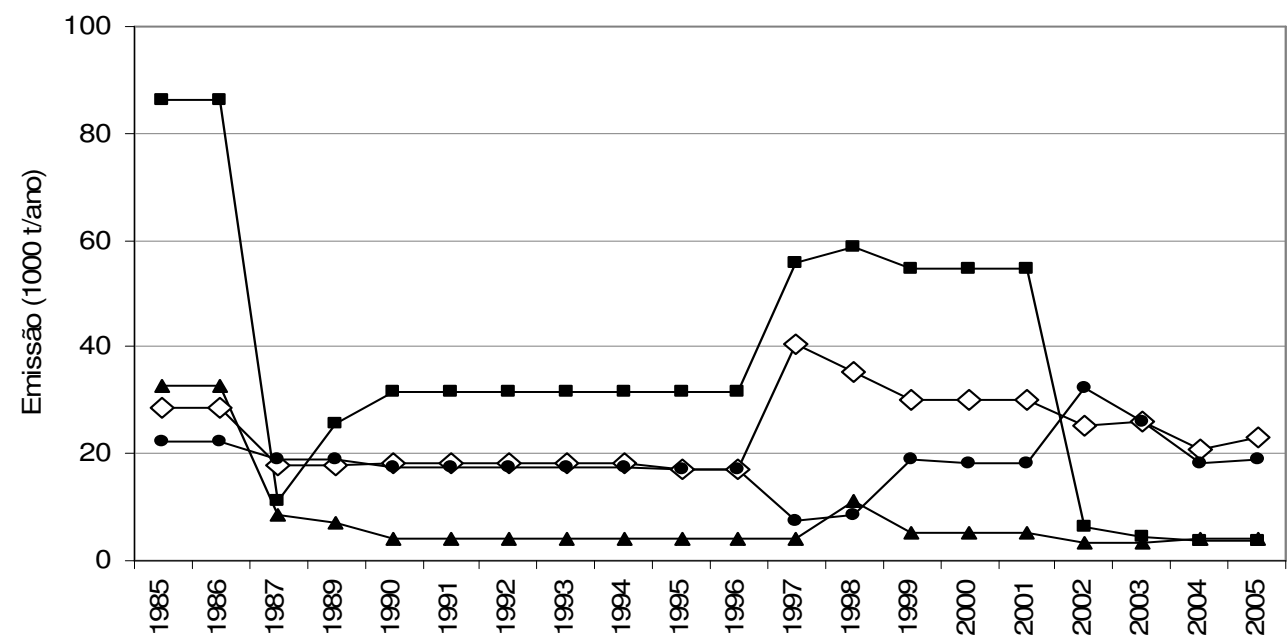

$$
\begin{array}{ll}
\longrightarrow \text { Material Particulado (MP) } & \prec \text { Dióxido de enxofre (SO2) } \\
\longrightarrow \text { Oxidos de nitrogênio (NOx) } & \multimap \text { Hidrocarbonetos }(\mathrm{HC})
\end{array}
$$




\section{INDICADOR:}

Distribuição anual do índice geral de qualidade do ar em Cubatão-Centro

\section{PARÂMETROS:}

Dados de qualidade do ar obtidos pela CETESB em suas estações automáticas de monitoramento, juntamente com uma previsão meteorológica das condições de dispersão dos poluentes para as 24 horas seguintes. Contempla os parâmetros: dióxido de enxofre, partículas totais em suspensão, partículas inaláveis, fumaça, monóxido de carbono, ozônio e dióxido de nitrogênio

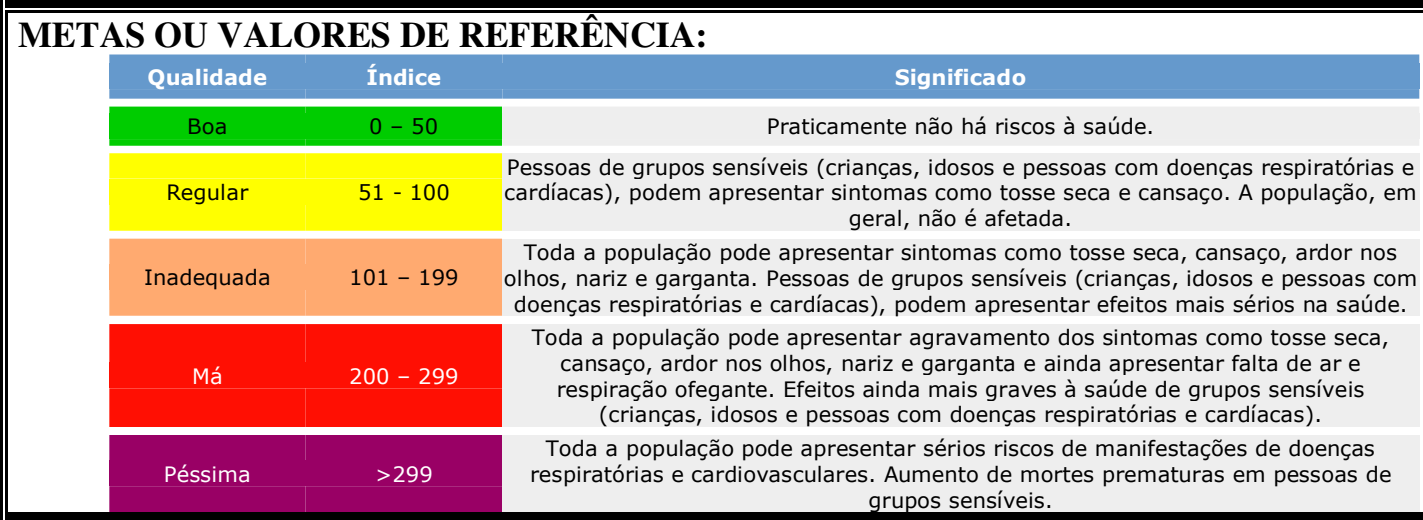

PROCEDIMENTO DE COLETA:

Consultar o site da CETESB (www.cetesb.sp.gov.br)

\section{ASPECTOS QUALITATIVOS PARA INTERPRETAÇÃO:}

Calculado o valor do índice, o ar recebe uma qualificação. A qualidade inadequada indica a ultrapassagem do padrão de qualidade do ar, a qualidade má, a ultrapassagem do nível de atenção, a péssima, a ultrapassagem do nível de alerta e a crítica, a ultrapassagem do nível de emergência

EVOLUCÃO:

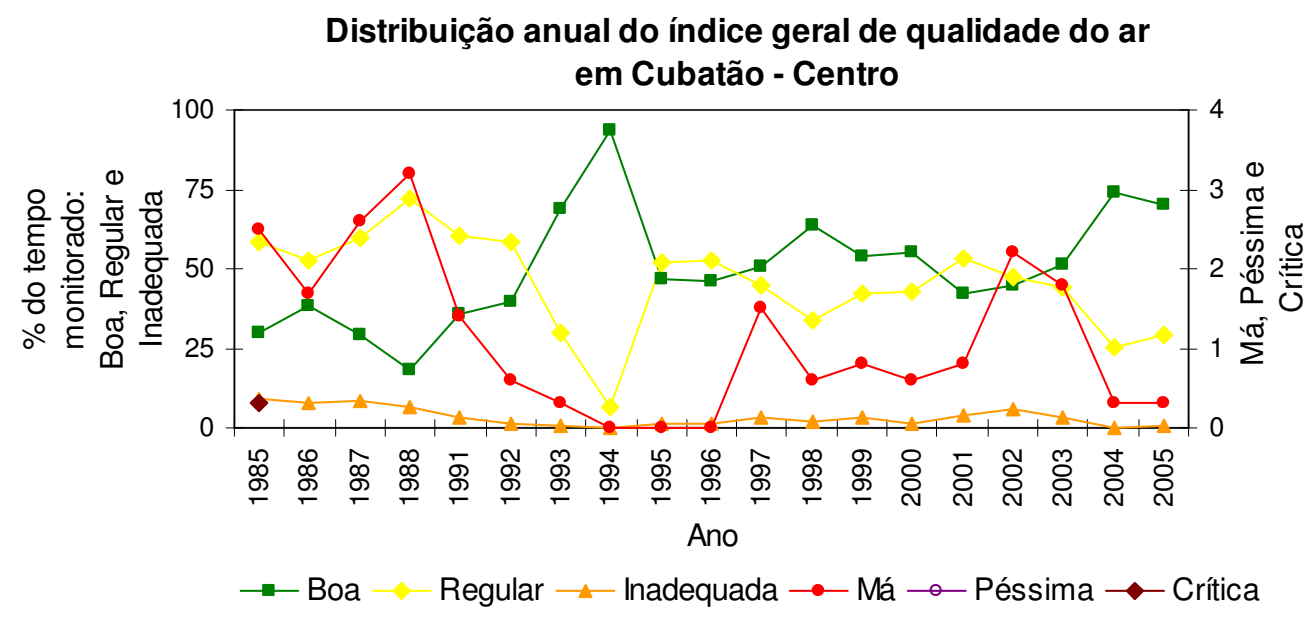




\section{INDICADOR:}

Distribuição anual do índice geral de qualidade do ar em Cubatão-Vila Parisi

\section{PARÂMETROS:}

Dados de qualidade do ar obtidos pela CETESB em suas estações automáticas de monitoramento, juntamente com uma previsão meteorológica das condições de dispersão dos poluentes para as 24 horas seguintes. Contempla os parâmetros: dióxido de enxofre, partículas totais em suspensão, partículas inaláveis, fumaça, monóxido de carbono, ozônio e dióxido de nitrogênio.

\section{METAS OU VALORES DE REFERÊNCIA:}

\begin{tabular}{|c|c|c|}
\hline Qualidade & Índice & Significado \\
\hline Boa & $0-50$ & Praticamente não há riscos à saúde. \\
\hline Regular & $51-100$ & $\begin{array}{c}\text { Pessoas de grupos sensíveis (crianças, idosos e pessoas com doenças respiratórias e } \\
\text { cardíacas), podem apresentar sintomas como tosse seca e cansaço. A população, em } \\
\text { geral, não é afetada. }\end{array}$ \\
\hline Inadequada & $101-199$ & $\begin{array}{l}\text { Toda a população pode apresentar sintomas como tosse seca, cansaço, ardor nos } \\
\text { olhos, nariz e garganta. Pessoas de grupos sensíveis (crianças, idosos e pessoas com } \\
\text { doenças respiratórias e cardíacas), podem apresentar efeitos mais sérios na saúde. }\end{array}$ \\
\hline Má & $200-299$ & $\begin{array}{l}\text { Toda a população pode apresentar agravamento dos sintomas como tosse seca, } \\
\text { cansaço, ardor nos olhos, nariz e garganta e ainda apresentar falta de ar e } \\
\text { respiração ofegante. Efeitos ainda mais graves à saúde de grupos sensíveis } \\
\text { (crianças, idosos e pessoas com doenças respiratórias e cardíacas). }\end{array}$ \\
\hline Péssima & $>299$ & $\begin{array}{l}\text { Toda a população pode apresentar sérios riscos de manifestações de doenças } \\
\text { respiratórias e cardiovasculares. Aumento de mortes prematuras em pessoas de } \\
\text { grupos sensíveis. }\end{array}$ \\
\hline
\end{tabular}

PROCEDIMENTO DE COLETA:

Consultar o site da CETESB (www.cetesb.sp.gov.br)

\section{ASPECTOS QUALITATIVOS PARA INTERPRETAÇÃO:}

Calculado o valor do índice, o ar recebe uma qualificação. A qualidade inadequada indica a ultrapassagem do padrão de qualidade do ar, a qualidade má, a ultrapassagem do nível de atenção, a péssima, a ultrapassagem do nível de alerta e a crítica, a ultrapassagem do nível de emergência

\section{EVOLUÇÃO:}

\section{Distribuição anual do índice geral de qualidade do ar em Cubatão - Vila Parisi}

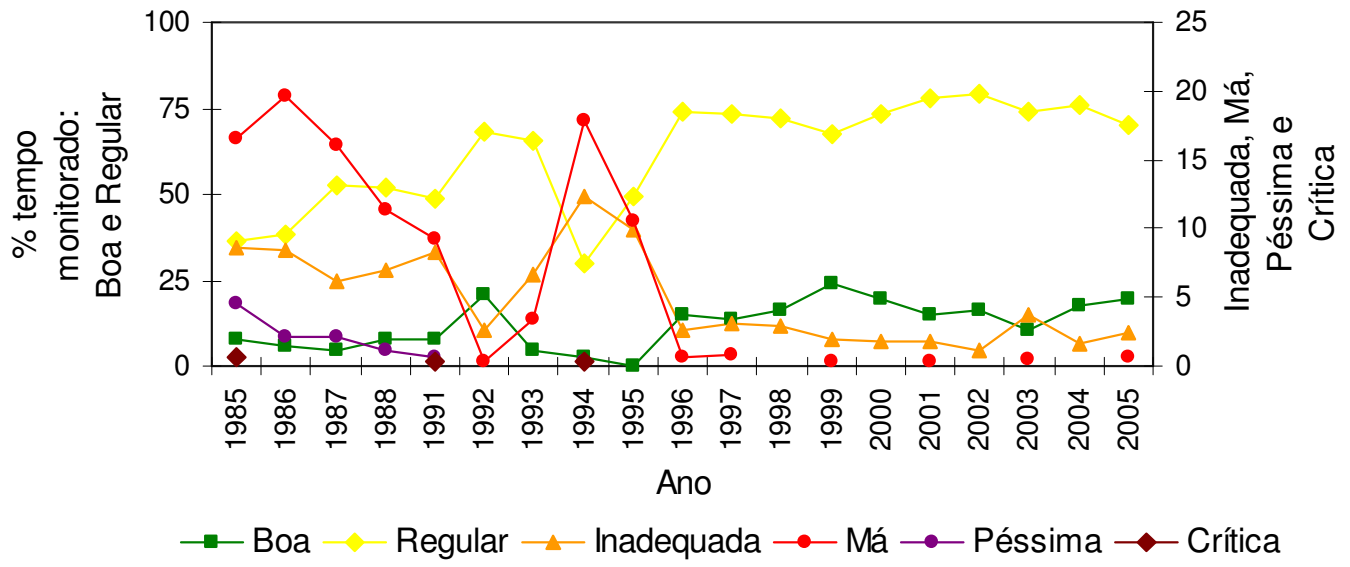




\section{INDICADOR:}

Distribuição anual da qualidade do ar em Cubatão-Centro para o parâmetro ozônio $\left(\mathrm{O}_{3}\right)$

\section{PARÂMETROS:}

Qualidade do ar para o parâmetro ozônio $\left(\mathrm{O}_{3}\right)$, considerando o número de dias monitorados durante o ano, em percentagem de tempo

METAS OU VALORES DE REFERÊNCIA:

Padrão de qualidade do ar para o parâmetro ozônio $\left(\mathrm{O}_{3}\right)$

\section{PROCEDIMENTO DE COLETA:}

Consultar o site da CETESB (www.cetesb.sp.gov.br)

\section{ASPECTOS QUALITATIVOS PARA INTERPRETAÇÃO:}

Expressa a distribuição temporal da qualidade do ar para o parâmetro ozônio $\left(\mathrm{O}_{3}\right)$ na região de Cubatão-Centro

\section{EVOLUÇÃO:}

\section{Distribuição anual da qualidade do ar em Cubatão Local: Centro Parâmetro: Ozônio $\left(\mathrm{O}_{3}\right)$}

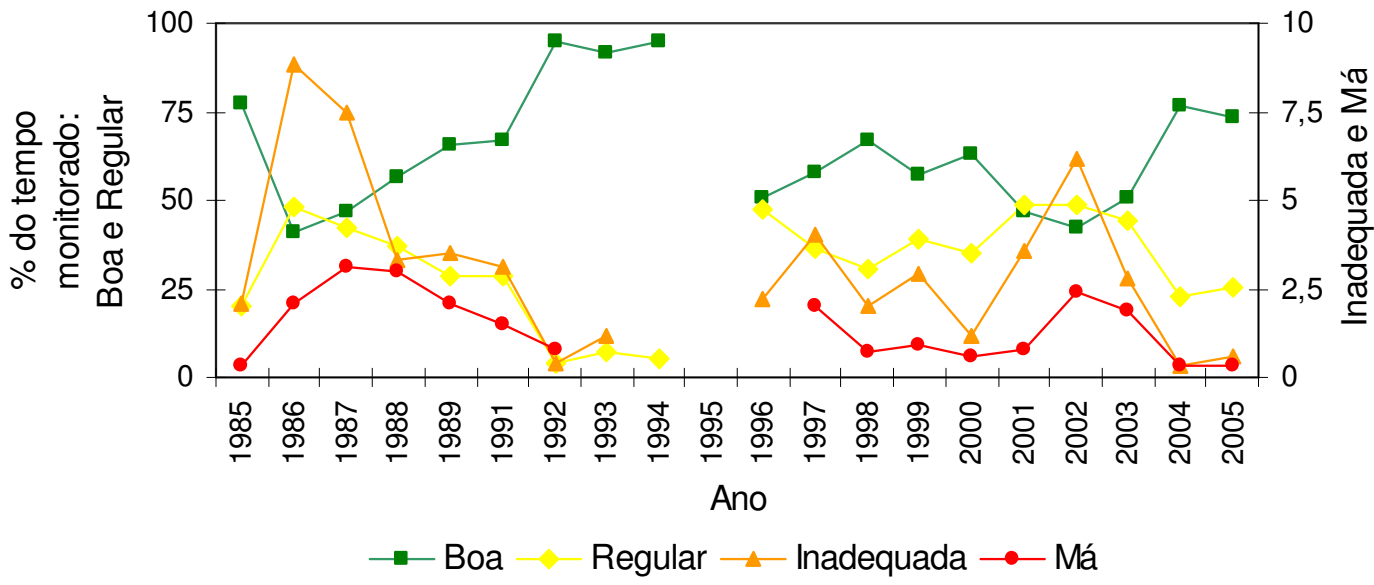




\section{INDICADOR:}

Distribuição anual da qualidade do ar em Cubatão-Centro para o parâmetro partículas inaláveis (PI)

PARÂMETROS:

Qualidade do ar para o parâmetro partículas inaláveis (PI), considerando o número de dias monitorados durante o ano, em percentagem de tempo

METAS OU VALORES DE REFERÊNCIA:

Padrão de qualidade do ar para o parâmetro partículas inaláveis (PI)

PROCEDIMENTO DE COLETA:

Consultar o site da CETESB (www.cetesb.sp.gov.br)

ASPECTOS QUALITATIVOS PARA INTERPRETAÇÃ̃:

Expressa a distribuição temporal da qualidade do ar para o parâmetro partículas inaláveis (PI) na região de Cubatão-Centro

EVOLUÇÃO:

\section{Distribuição anual da qualidade do ar em Cubatão Local: Centro Parâmetro: Partículas Inaláveis (PI)}

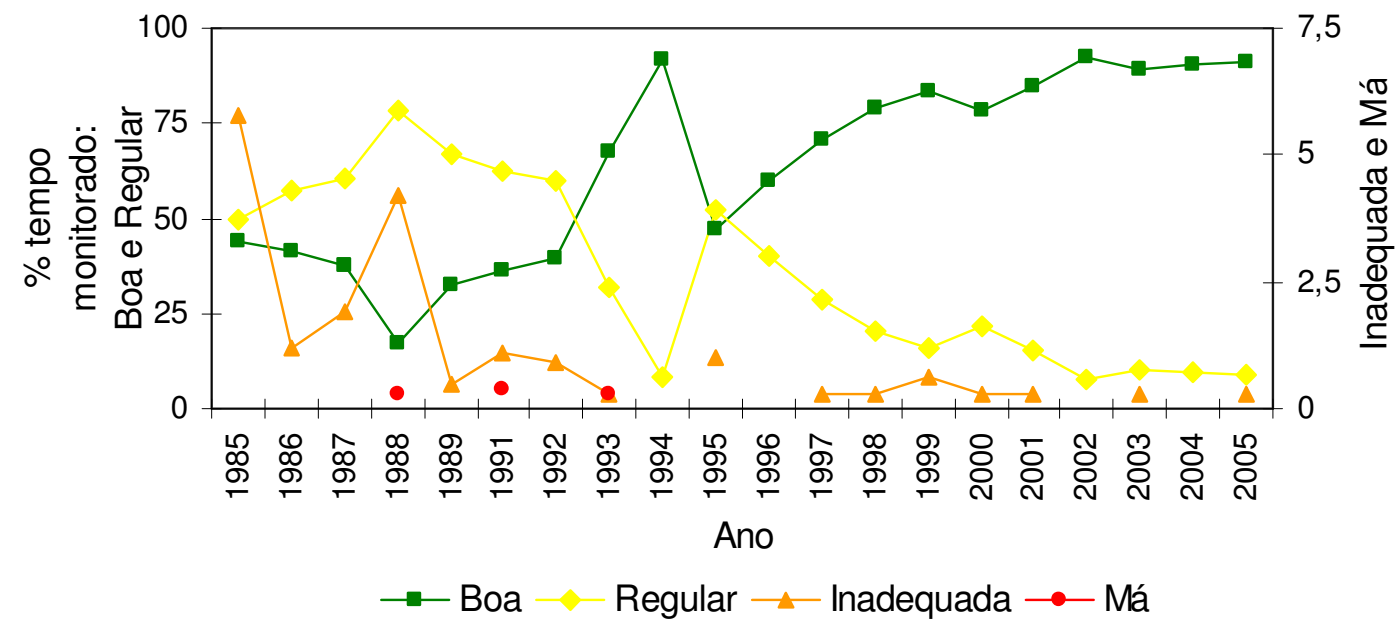




\section{INDICADOR:}

Distribuição anual da qualidade do ar em Cubatão-Vila Parisi para o parâmetro partículas inaláveis (PI)

\section{PARÂMETROS:}

Qualidade do ar para o parâmetro partículas inaláveis (PI), considerando o número de dias monitorados durante o ano, em percentagem de tempo.

\section{METAS OU VALORES DE REFERÊNCIA:}

Padrão de qualidade do ar para o parâmetro partículas inaláveis (PI)

\section{PROCEDIMENTO DE COLETA:}

Consultar o site da CETESB (www.cetesb.sp.gov.br)

\section{ASPECTOS QUALITATIVOS PARA INTERPRETAÇÃO:}

Expressa a distribuição temporal da qualidade do ar para o parâmetro partículas inaláveis (PI) na região de Cubatão-Vila Parisi

\section{EVOLUÇÃO:}

\section{Distribuição anual da qualidade do ar em Cubatão Local: Vila Parisi Parâmetro: Partículas Inaláveis (PI)}

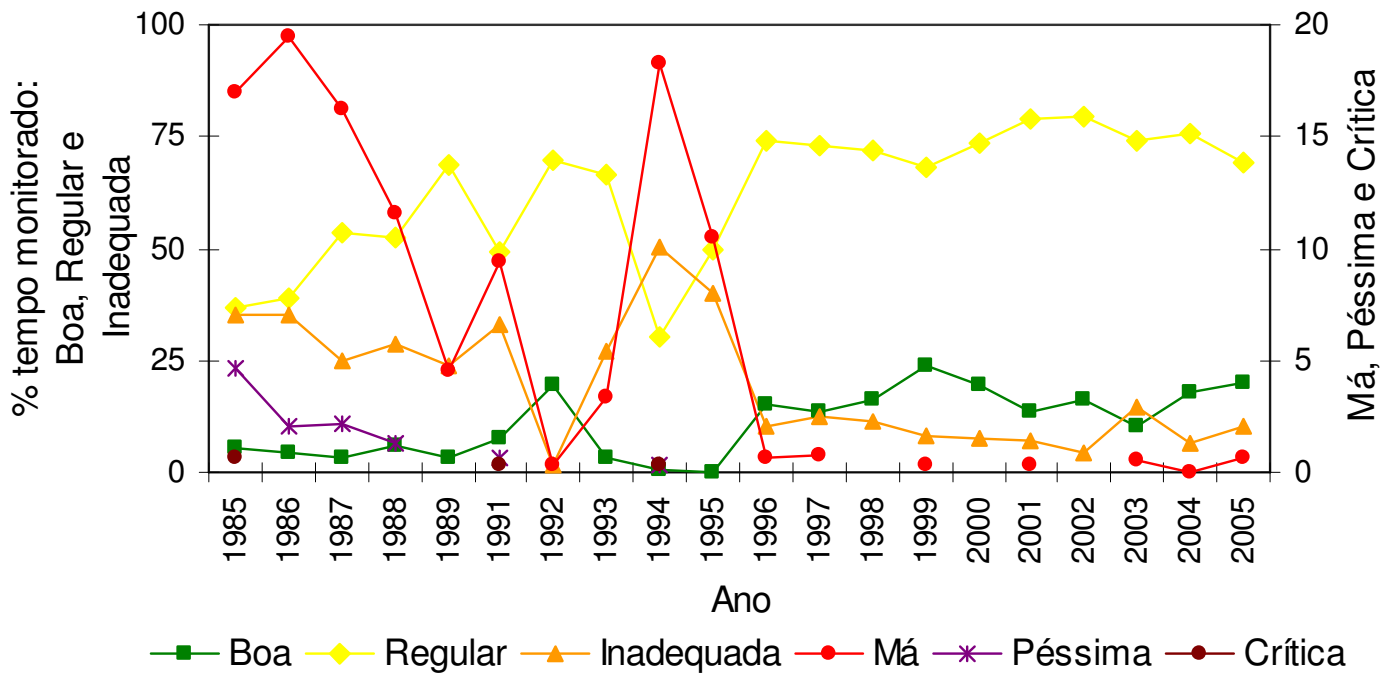




\section{INDICADOR:}

Índice anual de qualidade das águas (IQA 20\%) para os três principais rios do município: Rio Cubatão, Rio Mogi e Rio Piaçaguera

\section{PARÂMETROS:}

Produtório ponderado das qualidades das águas correspondentes a 09 (nove) parâmetros considerados como relevantes para essa avaliação: temperatura da amostra, $\mathrm{pH}$, oxigênio dissolvido, demanda bioquímica de oxigênio $\left(5\right.$ dias, $\left.20^{\circ} \mathrm{C}\right)$, coliforme fecal, nitrogênio total, fósforo total, resíduo total e turbidez

\section{METAS OU VALORES DE REFERÊNCIA:}

A qualidade das águas brutas é indicada pelo IQA, numa escala de 0 a 100, sendo classificada para abastecimento público, segundo a seguinte gradação:

- Qualidade Ótima $\quad 79<$ IQA $\leq 100$

- Qualidade Boa $\quad 51<$ IQA $\leq 79$

- Qualidade Regular $\quad 36<$ IQA $\leq 51$

- Qualidade Ruim $19<\mathrm{IQA} \leq 36$

- Qualidade Péssima $\quad$ IQA $\leq 19$

PROCEDIMENTO DE COLETA:

Consultar o site da CETESB (www.cetesb.sp.gov.br)

\section{ASPECTOS QUALITATIVOS PARA INTERPRETAÇÃO:}

Indica que durante $80 \%$ do tempo o ponto monitorado apresentou qualidade de água avaliada

como igual ou superior a este valor

\section{EVOLUÇÃO:}

Segundo a classificação qualitativa adotada, houve melhoria geral da qualidade das águas dos três rios monitorados. O Rio Cubatão apresenta melhores condições desde o início do programa. As condições dos Rios Mogi e Piaçaguera começaram a melhorar somente a partir do ano 2000 e 2002 , respectivamente. 


\section{INDICADOR:}

Abastecimento de água-Nível de atendimento (em \%)

PARÂMETROS:

Porcentagem de domicílios particulares permanentes urbanos atendidos por rede geral de abastecimento de água

METAS OU VALORES DE REFERÊNCIA:

$100 \%$ de atendimento

PROCEDIMENTO DE COLETA:

Consultar o site da Fundação SEADE (www.seade.sp.gov.br)

ASPECTOS QUALITATIVOS PARA INTERPRETAÇÃO:

Expressa o nível de atendimento de domicílios particulares permanentes urbanos do município pelo serviço público de abastecimento de água

EVOLUÇ̃̃̃:

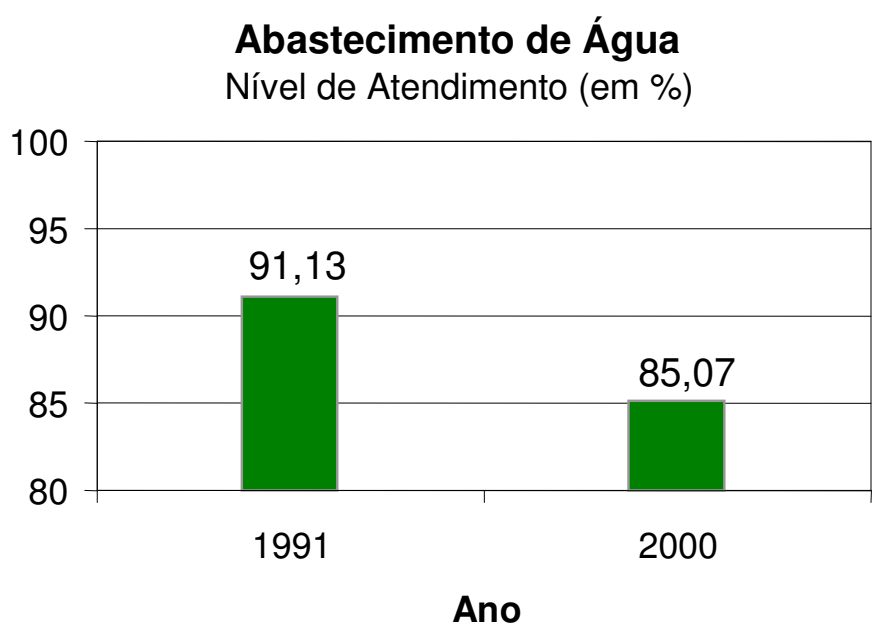




\section{INDICADOR:}

Coleta de lixo - Nível de atendimento (em \%)

PARÂMETROS:

Porcentagem de domicílios particulares permanentes urbanos atendidos por serviço regular de coleta de lixo

METAS OU VALORES DE REFERÊNCIA:

$100 \%$ de atendimento

PROCEDIMENTO DE COLETA:

Consultar o site da Fundação SEADE (www.seade.sp.gov.br)

ASPECTOS QUALITATIVOS PARA INTERPRETAÇÃO:

Expressa o nível de atendimento de domicílios particulares permanentes urbanos do município pelo serviço público de coleta de lixo

\section{EVOLUÇÃO:}

\section{Coleta de Lixo}

Nível de Atendimento (em \%)

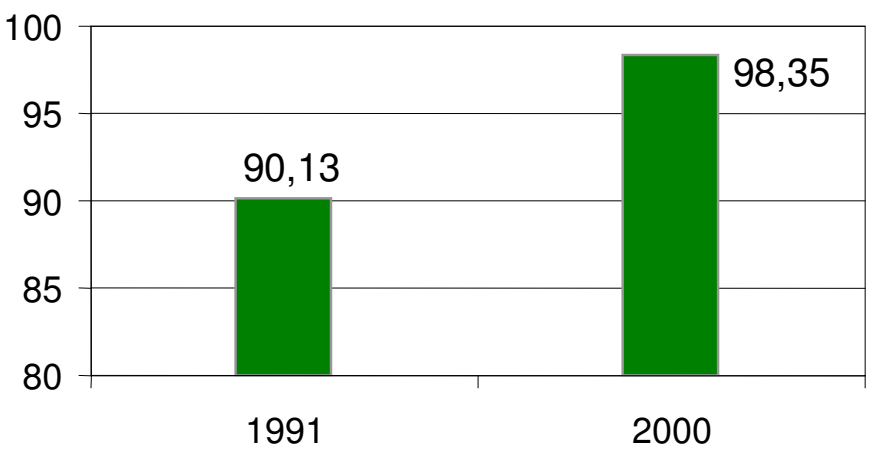

Ano 


\section{INDICADOR:}

Esgoto sanitário-Nível de atendimento (em \%)

PARÂMETROS:

Porcentagem de domicílios particulares permanentes urbanos atendidos por rede geral de esgoto sanitário

METAS OU VALORES DE REFERÊNCIA:

$100 \%$ de atendimento

PROCEDIMENTO DE COLETA:

Consultar o site da Fundação SEADE (www.seade.sp.gov.br)

ASPECTOS QUALITATIVOS PARA INTERPRETAÇÃO:

Expressa o nível de atendimento de domicílios particulares permanentes urbanos do município pelo serviço público de esgotamento sanitário

\section{EVOLUÇÃO:}

\section{Esgoto Sanitário}

Nível de Atendimento (em \%)

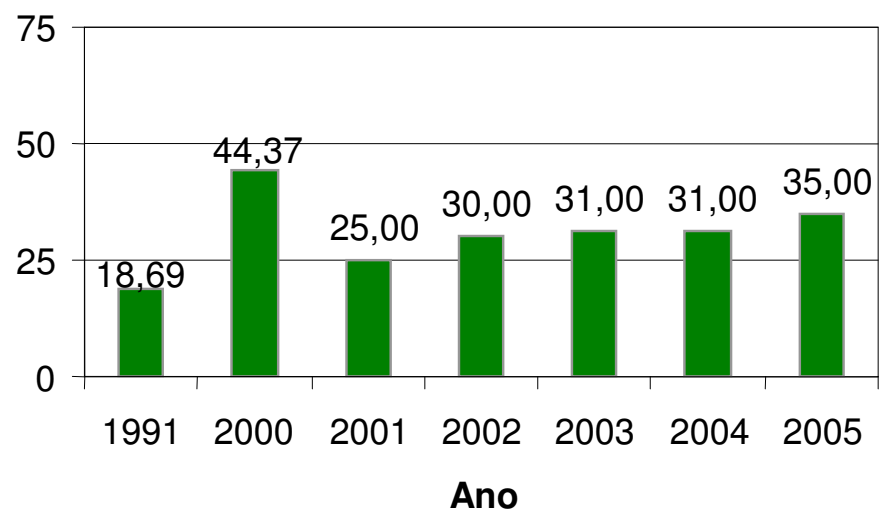




\section{INDICADOR:}

Taxa de mortalidade infantil (por mil nascidos vivos)

\section{PARÂMETROS:}

Relação entre os óbitos de menores de um ano de residentes numa unidade geográfica, num determinado período de tempo (geralmente um ano) e os nascidos vivos da mesma unidade nesse período, segundo a fórmula:

$$
\text { Taxa de mortalidade infantil }=\underline{\text { Óbitos de menores de } 1 \text { ano }} \times 1000
$$

\section{Nascidos vivos}

\section{METAS OU VALORES DE REFERÊNCIA:}

Redução da mortalidade infantil

PROCEDIMENTO DE COLETA:

Consultar o site da Fundação SEADE (www.seade.sp.gov.br)

\section{ASPECTOS QUALITATIVOS PARA INTERPRETAÇÃO:}

Indica o risco de morte infantil através da frequiência de óbitos de menores de um ano de idade na população de nascidos vivos

\section{EVOLUÇ̃̃̃:}

Taxa de mortalidade infantil em Cubatão

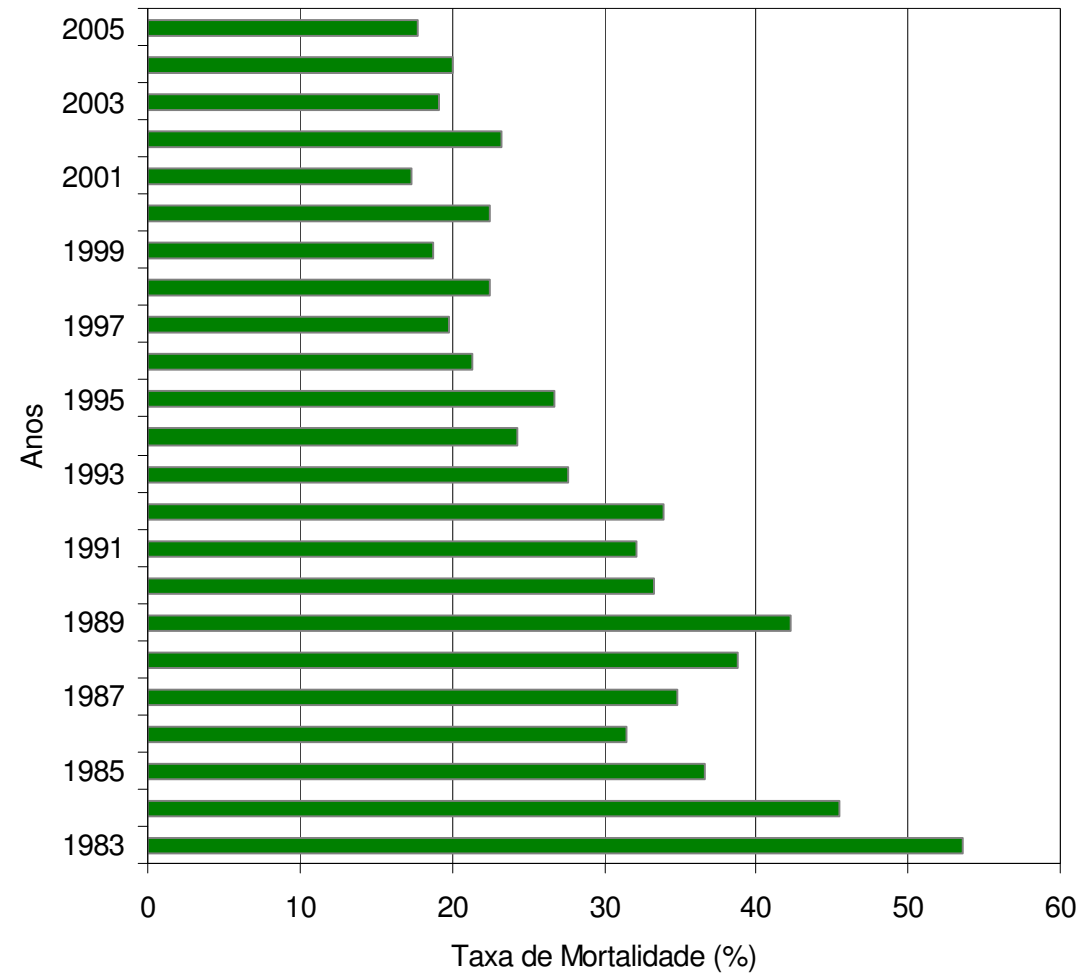




\section{INDICADOR: \\ Média de anos de estudos da população de 15 a 64 anos

PARÂMETROS:

Número médio de anos de estudo da população na faixa etária indicada

METAS OU VALORES DE REFERÊNCIA:

Melhoria da escolaridade da população

PROCEDIMENTO DE COLETA:

Consultar o site da Fundação SEADE (www.seade.sp.gov.br)

ASPECTOS QUALITATIVOS PARA INTERPRETAÇÃO:

Expressa o nível educacional da população do município na faixa etária indicada

EVOLUÇÃ̃:

Não foi possível verificar a evolução, em razão do dado existir somente para o ano 2000: 6,84. Com a finalidade de possibilitar alguma comparação foi utilizado o mesmo indicador para o total do Estado de São Paulo: 7,64. 


\section{INDICADOR:}

População de 25 anos e mais com menos de 8 anos de estudo

PARÂMETROS:

Percentual da população de 25 anos e mais com menos de 8 anos de estudo em relação à população total da mesma faixa etária

METAS OU VALORES DE REFERÊNCIA:

Melhoria da escolaridade da população adulta

PROCEDIMENTO DE COLETA:

Consultar o site da Fundação SEADE (www.seade.sp.gov.br)

ASPECTOS QUALITATIVOS PARA INTERPRETAÇÃO:

Expressa o nível educacional da população do município que está fora da idade escolar

EVOLUÇÃO:

Não foi possível verificar a evolução, em razão do dado existir somente para o ano 2000: $60,73 \%$. Com a finalidade de possibilitar alguma comparação foi utilizado o mesmo indicador para o total do Estado de São Paulo: 55,55\%. 


\section{INDICADOR:}

IDH Municipal

PARÂMETROS:

Diversos, abrangendo as dimensões de longevidade, educação e renda, que participam com pesos iguais na sua determinação, focalizando o município como unidade de análise

METAS OU VALORES DE REFERÊNCIA:

O IDHM se situa entre 0(zero) e 1(um)

PROCEDIMENTO DE COLETA:

Consultar o site da Fundação SEADE (www.seade.sp.gov.br)

ASPECTOS QUALITATIVOS PARA INTERPRETAÇÃO:

Os valores distribuem-se em três categorias:

a) Baixo desenvolvimento humano, quando o IDHM for menor que 0,500;

b) Médio desenvolvimento humano, para valores entre 0,500 e 0,800;

c) Alto desenvolvimento humano, quando o índice for superior a 0,800.

EVOLUÇÃO:

Índice de Desenvolvimento Humano (IDH)

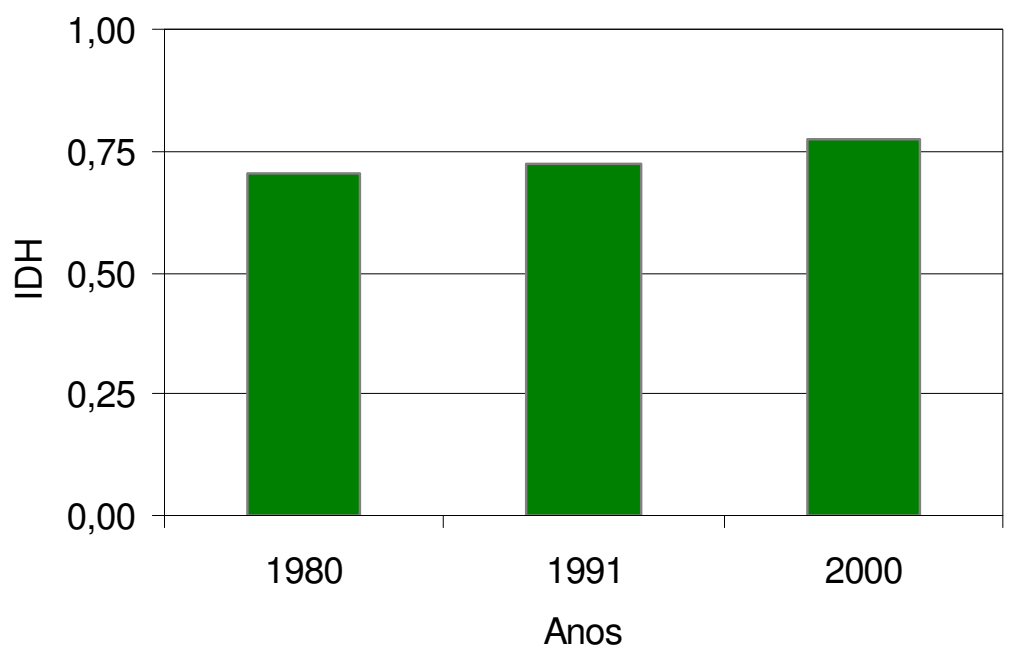




\section{INDICADOR:}

IPRS-Índice Paulista de Responsabilidade Social

PARÂMETROS:

Diversos, abrangendo as dimensões riqueza, escolaridade e longevidade

METAS OU VALORES DE REFERÊNCIA:

Obter a classificação no Grupo 1 do indicador

PROCEDIMENTO DE COLETA:

Consultar o site da Fundação SEADE (www.seade.sp.gov.br)

ASPECTOS QUALITATIVOS PARA INTERPRETAÇÃO:

Os municípios, conforme critérios baseados nas dimensões riqueza, escolaridade e longevidade, são classificados em cinco grupos:

Grupo 1- Municípios que se caracterizam por um nível elevado de riqueza, com bons níveis nos indicadores sociais

Grupo 2- Municípios que, embora com níveis de riqueza elevados, não são capazes de atingir bons indicadores sociais

Grupo 3- Municípios com nível de riqueza baixo, mas com bons indicadores sociais

Grupo 4- Municípios que apresentam baixos níveis de riqueza e níveis intermediários de longevidade e/ou escolaridade

Grupo 5- Municípios mais desfavorecidos do Estado, tanto em riqueza como nos indicadores sociais

\section{EVOLUÇÃO:}

Desde a sua criação, no ano 2000, até o ano de 2004, não houve melhoria do indicador para o município de Cubatão, que permanece classificado no Grupo 2. 


\section{INDICADOR:}

IPVS-Índice Paulista de Vulnerabilidade Social

PARÂMETROS:

Diversos, agregando indicadores de renda, escolaridade e ciclo de vida familiar, adotando-se como unidade de análise os setores censitários utilizados pelo IBGE na realização do Censo Demográfico

METAS OU VALORES DE REFERÊNCIA:

Redução das desigualdades sociais no interior dos municípios

PROCEDIMENTO DE COLETA:

Consultar o site da Fundação SEADE (www.seade.sp.gov.br)

\section{ASPECTOS QUALITATIVOS PARA INTERPRETAÇÃO:}

Os setores censitários dos municípios são classificados em seis categorias, segundo o grau de vulnerabilidade social da população neles residente, em percentual sobre o total da população do município:

Grupo 1- Nenhuma vulnerabilidade

Grupo 2- Vulnerabilidade muito baixa

Grupo 3- Vulnerabilidade baixa

Grupo 4- Média vulnerabilidade

Grupo 5- Vulnerabilidade alta

Grupo 6- Vulnerabilidade muito alta

\section{EVOLUÇÃO:}

Não foi possível verificar a evolução, em razão dos dados existirem somente para o ano 2000. A classificação da população do município de Cubatão para esse ano, em percentual da população exposta, é a seguinte:

-Grupo 1 - 0,37

-Grupo $2-16,10$

-Grupo 3 - 23,34

-Grupo $4-17,97$

-Grupo 5 - 21,19

-Grupo 6 - 21,04 


\section{INDICADOR:}

PIB per capita

PARÂMETROS:

Representa o total dos bens e serviços produzidos pelas unidades produtoras, ou seja, a soma dos valores adicionados acrescida dos impostos, dividido pela população da respectiva unidade geográfica

METAS OU VALORES DE REFERÊNCIA:

Melhoria contínua

PROCEDIMENTO DE COLETA:

Consultar o site da Fundação SEADE (www.seade.sp.gov.br)

ASPECTOS QUALITATIVOS PARA INTERPRETAÇÃO:

Expressa o desenvolvimento econômico do município

EVOLUÇÃ̃:

Produto Interno Bruto (PIB) per capita do município de Cubatão

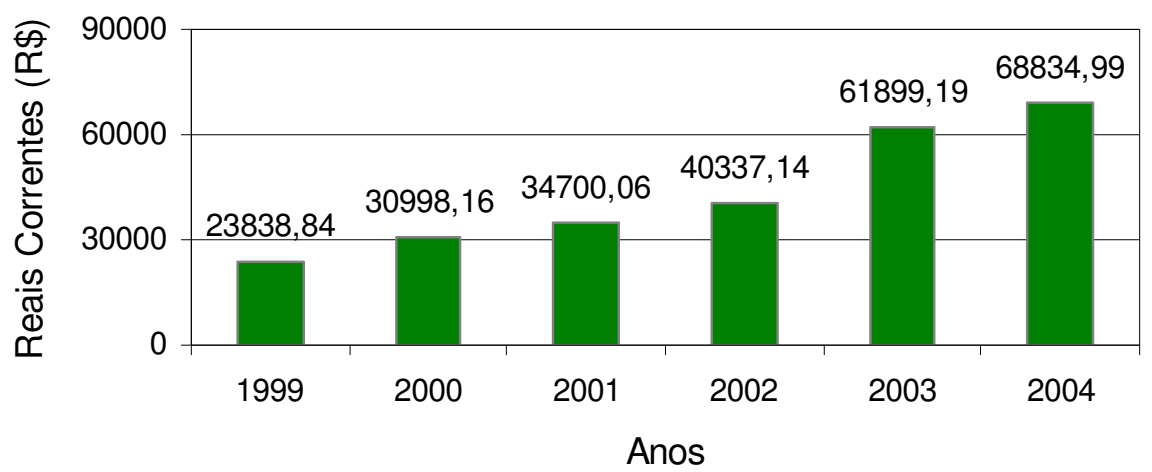




\section{INDICADOR:}

Percentual de despesas com gestão ambiental no total do orçamento do município

PARÂMETROS:

Porcentagem do gasto público com proteção do meio ambiente sobre o total do orçamento do município

METAS OU VALORES DE REFERÊNCIA:

Não se aplica

PROCEDIMENTO DE COLETA:

Consultar o site da Fundação SEADE (www.seade.sp.gov.br)

ASPECTOS QUALITATIVOS PARA INTERPRETAÇÃO:

Expressa a capacidade de atuação e o grau de comprometimento do município na proteção do meio ambiente

EVOLUÇÃ̃:

Percentual de Despesas com Gestão Ambiental

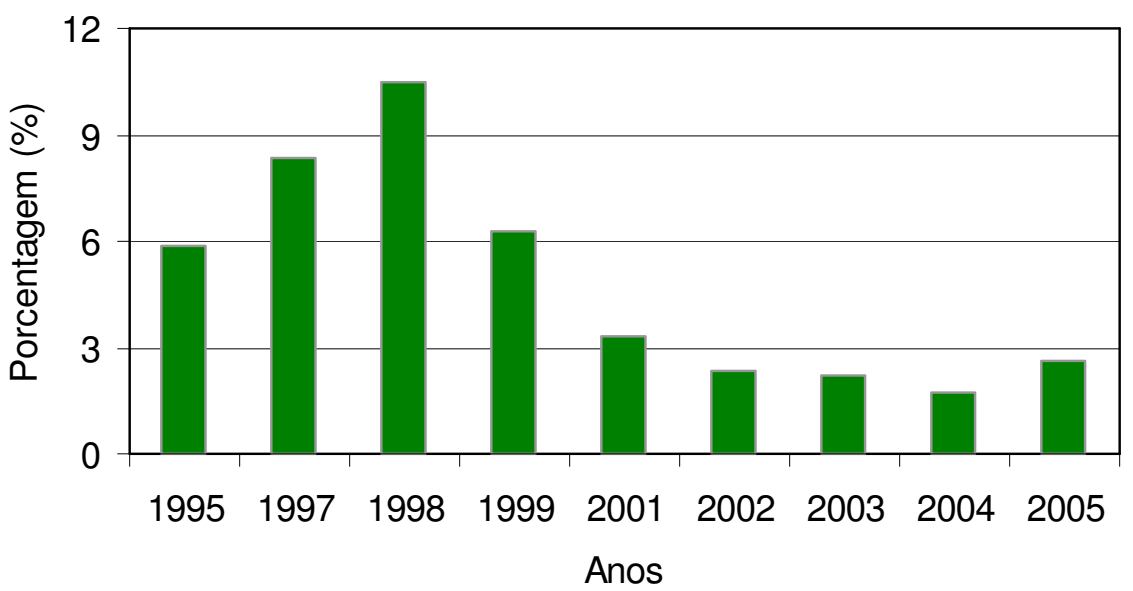




\section{INDICADOR:}

Existência de Conselho Municipal de Meio Ambiente em atividade

PARÂMETROS:

Existência de Conselho Municipal de Meio Ambiente em atividade

METAS OU VALORES DE REFERÊNCIA:

Não se aplica

PROCEDIMENTO DE COLETA:

Consultar o site da Fundação SEADE (www.seade.sp.gov.br)

ASPECTOS QUALITATIVOS PARA INTERPRETAÇÃO:

Expressa o nível de organização municipal no que se refere à democratização da gestão de políticas públicas ambientais

EVOLUÇÃO:

O município de Cubatão não tem Conselho Municipal de Meio Ambiente ativo 


\section{INDICADOR:}

Existência de leis municipais específicas para proteção ou controle ambiental

PARÂMETROS:

Número de leis municipais específicas para proteção ou controle ambiental

METAS OU VALORES DE REFERÊNCIA:

Não se aplica

PROCEDIMENTO DE COLETA:

Consultar o site da Fundação SEADE (www.seade.sp.gov.br)

ASPECTOS QUALITATIVOS PARA INTERPRETAÇÃO:

Expressa a capacidade de atuação e o grau de comprometimento do município na proteção do meio ambiente

EVOLUÇÃO:

O município de Cubatão não tem leis específicas para proteção ou controle ambiental 


\section{INDICADOR:}

Ações Civis Públicas propostas e Termos de Ajustamento de Conduta formalizados pelo Ministério Público de São Paulo em Cubatão

\section{PARÂMETROS:}

Número de Ações Civis Públicas propostas e Termos de Ajustamento de Conduta formalizados pelo Ministério Público de São Paulo em Cubatão, no período de um ano

METAS OU VALORES DE REFERÊNCIA:

Não se aplica

PROCEDIMENTO DE COLETA:

Registros do Ministério Público e do Cartório Distribuidor da Comarca de Cubatão

ASPECTOS QUALITATIVOS PARA INTERPRETAÇÃO:

Expressa a utilização pelo Ministério Público dos instrumentos legais à disposição da sociedade para a tutela do meio ambiente

EVOLUÇÃO:

\section{Ações Civis Públicas (ACPs) Propostas e Termos de Compromisso de Ajustamento de Conduta (TACs) Formalizados pelo Ministério Público.}

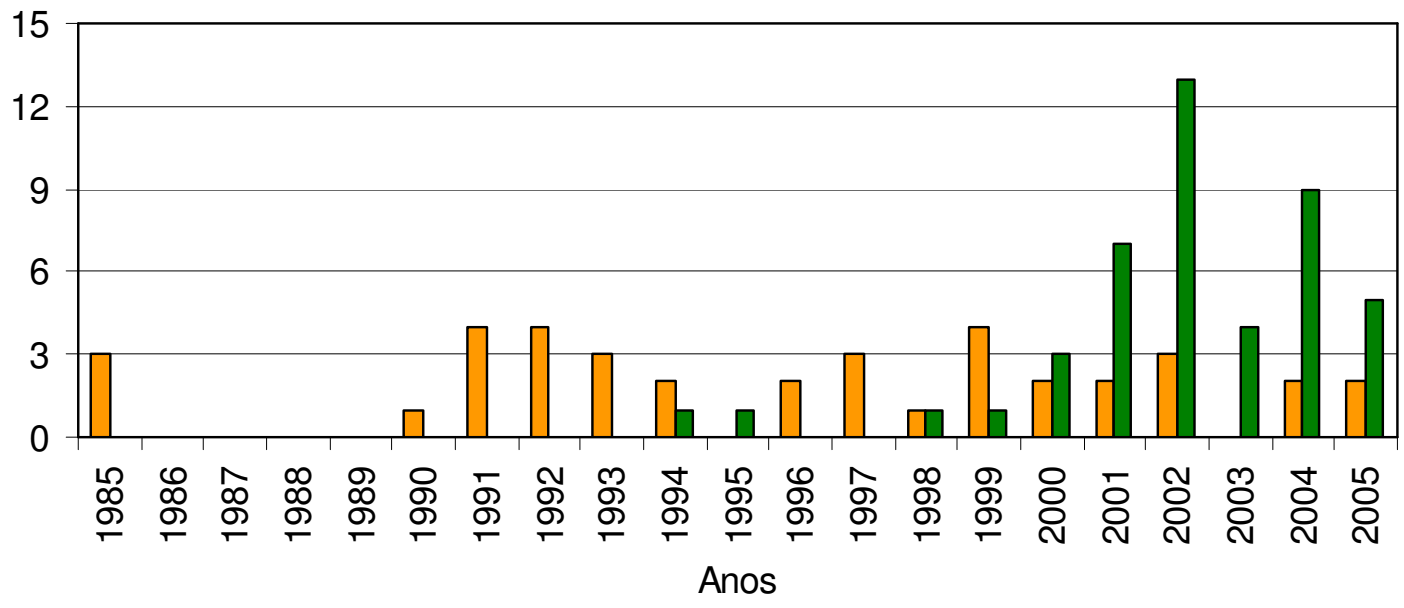

$\square$ ACPs $\square$ TACs 
